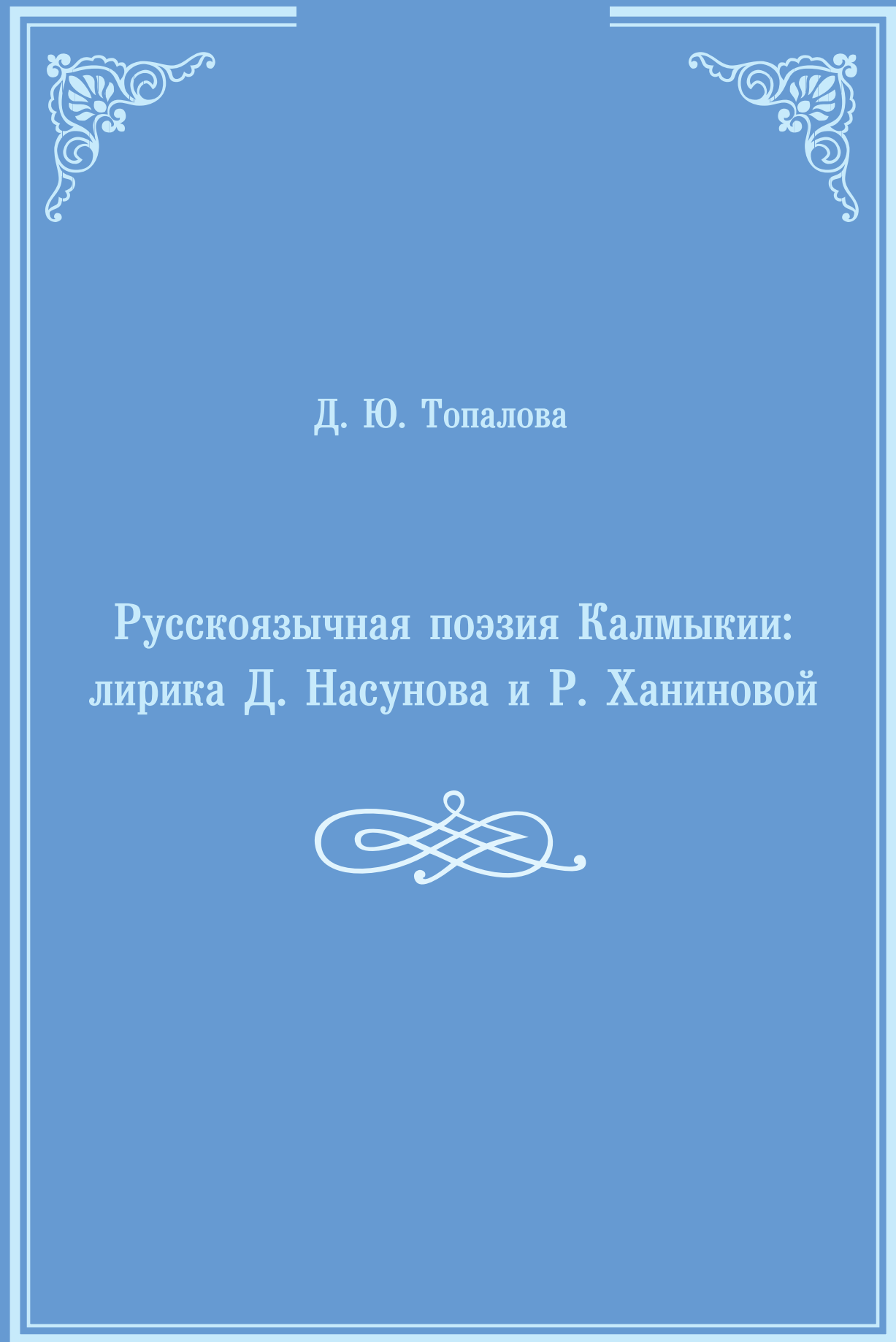


Федеральное государственное бюджетное учреждение науки Калмыцкий институт гуманитарных исследований Российской академии наук

\author{
Д. Ю. Топалова
}

\title{
Русскоязычная поэзия Калмыкии: лирика Д. Насунова и Р. Ханиновой
}

\author{
Монография
}

Элиста

2014 
ББК 83.3 (2Рос=Калм)

УДК $82-1 / 9$

Т 58

Утверждено к печати Ученым советом

Федерального государственного бюджетного учреждения науки

Калмыцкий институт гуманитарных исследований Российской академии наук

Ответственный редактор

Е. Е. Балданмаксарова - д.ф.н,

доцент кафедры русской и зарубежной литературы

Бурятского государственного университета

Рецензенты:

С. Н. Цеденова — к.ф.н., доцент, зав. кафедрой калмыцкой литературы и журналистики Калмыцкого государственного университета

М. А. Лиджиев - к.ф.н., доцент кафедры калмыцкой литературы и журналистики Калмыцкого государственного университета

\section{Топалова Д. Ю.}

Т 58 Русскоязычная поэзия Калмыкии: лирика Д. Насунова и Р. Ханиновой: Монография. [Текст] Д. Ю. Топалова; / отв. ред. Е. Е. Балданмаксарова. - Элиста: КИГИ РАН, 2014. - 256 с.

Монография посвящена малоисследованному явлению в литературном процессе Калмыкии - русскоязычной поэзии, становление которой происходило на протяжении XX века. В работе анализируются процесс становления и развития русскоязычной поэзии Калмыкии, ее художественно-эстетическое своеобразие в контексте развития литературы народов Российской Федерации. Книга адресована специалистамлитературоведам, востоковедам, а также широкому кругу читателей, интересующихся современными процессами в развитии литературы народов нашей страны.

ISBN 978-5-903833-62-7

(C) Топалова Д. Ю., 2014

(c) КИГИ РАН, 2014 


\section{СОДЕРЖАНИЕ}

Введение . . . . . . . . . . . . . . . . 5

ГЛАВА І. Этнонациональная идентичность как основная тенденция формирования и развития русскоязычной литературы Калмыкии . . . . . . . . . . . . . . . . . . . . . . . . 12

1.1. Становление русскоязычной литературы Калмыкии в 1920-1930-е гг. . . . . . . . . . . . . . . . . . . . . 12

1.2. Развитие русскоязычной литературы Калмыкии в конце 1960-х - 1980-е гг. . . . . . . . . . . . . . . . . . 25 1.3. Развитие русскоязычной поэзии Калмыкии в 1990 -2000-е гг. (тенденции, тематический состав, жанровая система) . . . . . . . . . . . . . . . 31

ГЛАВА ІІ. Этнокультурное пространство поэзии Д. Насунова 56

2.1. Поиск этнонациональной идентичности и этнокультурные концепты как основа художественной картины мира в поэзии Д. Насунова . . . . . . . . . . . . . . . . . 56

2.2. Исповедальная поэзия Д. Насунова 1978-1979 гг. . . 101

ГЛАВА ІІІ. Взаимодействие восточных и европейских культурных традиций в поэзии Р. Ханиновой . . . . . . . . . . 118

3.1. Поэзия Р. Ханиновой в аспекте диалога . . . . . . . . . 118

3.2. Идеи ценности синтеза, или взаимодействие традиций

Востока и Запада в творчестве Р. Ханиновой . . . . . . . . 147 Заключение . . . . . . . . . . . . . . . . . . . . . . . . 186 Список использованной литературы … . . . . . . . . . . 198 



\section{ВВЕДЕНИЕ}

Данная работа посвящена исследованию русскоязычной поэзии в литературном процессе Калмыкии.

Традиция русскоязычной литературы Калмыкии берет начало в 1920-е гг. — в начале нового этапа развития калмыцкой литературы. Почти за вековой период накоплен значительный литературный опыт, возникли новые аспекты художественного осмысления различных тем и проблем, связанных с преобразованиями в обществе, трансформацией сознания человека под воздействием глобальной социокультурной ситуации в стране и мире.

В настоящее время русскоязычная литература Калмыкии представляет собой только складывающуюся систему, которая является органичной частью общероссийского литературного процесса. В калмыцкой литературе можно выделить три группы авторов. Первую формируют поэты и писатели, пишущие на родном языке; вторую составляют авторы, создающие произведения как на русском, так и на калмыцком языках; в третью входят те, кто создает произведения преимущественно на русском языке языке свободного владения. Параллельно с процессом развития русскоязычной литературы развивается также русская литература Калмыкии, которую представили поэты и писатели славянской национальности, пишущие на русском языке.

Как известно, каждая национальная литература проходит свой путь осмысления проблем этнокультурной идентичности, межкультурного, межлитературного диалога, благодаря чему создаются самобытные произведения, в которых используются разные национальные коды, ведущие к пониманию общечеловеческих ценностей, единства национального и всеобщего. Однако история становления и развития русскоязычной поэзии Калмыкии в аспекте обозначенной нами проблемы до сих пор практически не исследована в калмыцком литературоведении, что обусловливает актуальность настоящей работы. 
Для русскоязычного поэта поиск этнонациональной идентичности - это не только обозначение определенных элементов литературной традиции, не только стремление выделить ключевые символические образы и концепты национального сознания, особенности той или иной культуры, но и выход к межлитературной, межкультурной коммуникации. Обозначенный литературоведческий дискурс рассматривается нами как основополагающая идея все расширяющегося контекста. Данные проблемы исследуются не только в рамках художественной системы поэтов в целом, но и с точки зрения художественного новаторства, оригинальности мировидения, основанного на синтезе разных культур, прежде всего калмыцкой и русской.

Для всестороннего понимания и осмысления калмыцкого художественного русскоязычия нами выявлены наиболее значимые этапы его развития: 1920-1930-е гг., конец 1960-х - 1980-е гг. и 1990-е гг. - первое десятилетие XXI в. В данную периодизацию не входят годы Великой Отечественной войны (1941-1945) и депортации калмыцкого народа (1943-1956), так как в это время развитие национальной литературы вынужденно приостановилось.

Истоком формирования русскоязычной поэзии явилась русскоязычная проза, связанная с именами таких писателей, как А. Амур-Санан, С. Балыков, О. Манджиев. Они активно повлияли на процесс формирования и развития калмыцкой русскоязычной литературы в целом. Поэтому анализу их творчества в данной работе уделено достаточное внимание.

В настоящем исследовании рассматривается творчество поэта Д. Насунова, пришедшееся на сравнительно недавние 1970-е гг., который внес существенный вклад и новые интонации не только в развитие русскоязычной поэзии, но и шире - всей калмыцкой литературы. Его поэзия стала первым и серьезным свидетельством того, что национально-духовную сущность возможно выразить не только на родном языке. Однако в тот период, когда в поэзию пришел Д. Насунов, в идеологии и, соответственно, в литературе имела большую силу догма, согласно которой только творчество 
авторов на родном языке считалось «лигитимным», то есть безоговорочно относилось к явлению национальной литературы. Русскоязычное творчество калмыцких поэтов и писателей рассматривалось как второсортное и полностью игнорировалось. Более того, русскоязычным авторам приписывалось и вменялось в вину отрешение от национальных корней, национального самосознания, национальных традиций. Поэтому Д. Насунов не был официально признан как при жизни, так и некоторое время после смерти. Его поэзия долго не изучалась исследователями, не включалась ни в школьную, ни в вузовскую программы.

Как отмечает поэт, литературовед и критик Р. Ханинова, сегодня творчество Д. Насунова можно с полным основанием отнести к «возвращенной литературе». Впервые оно было рассмотрено в исследовательской работе лишь в 2007 г. Э. В. Лубинецким. Позже жизнь и творчество калмыцкого художника слова получило освещение в учебном пособии «Современная русскоязычная поэзия Калмыкии» (Элиста, 2013).

Рассмотрение творчества Д. Насунова в данной работе имеет особую актуальность в связи с тем, что мнение о невозможности создать подлинно национальную литературу на ином, не родном, языке в настоящее время если не имеет характер догмы, все же не изжито окончательно. В то время как в связи с современной тенденцией к самоидентификации каждой нации важно понять, что национальное самоутверждение не должно сводиться к разрыву связей культур и литератур, к замыканию в ограниченном языковом пространстве. Напротив, творческое взаимовлияние, открытость диалогу на всех уровнях художественного творчества, в том числе языковом, насущно необходимы. И поэзия Д. Насунова - яркий тому пример.

В работе также анализируется творчество Р. Ханиновой, чей вклад в развитие калмыцкой русскоязычной поэзии неоспорим. Для ее поэзии характерна выраженная национальная составляющая, при том, что языком творчества автор, владеющая родным языком, сознательно выбрала русский язык. Поэзии Р. Ханиновой 
в равной степени присущи как интеллектуальность, философичность, диалогичность, так и глубинная связь с фольклором, традиционной культурой народа. Это позволяет автору оригинально и полно воплотить этнонациональную идентичность своего художественного мира. В этом направлении поэт многого достигла и внесла ощутимую лепту в развитие литературного процесса.

Цель исследования заключается в изучении процессов становления и развития русскоязычной поэзии Калмыкии, её художественно-эстетического своеобразия в контексте развития литературы народов Российской Федерации, выявления проблем национальной идентичности с опорой на этнонациональные литературные традиции и культурные коды, а также с выходом на проблемы межкультурного диалога.

Цель исследования обусловливает решение следующих задач:

- изучить особенности функционирования русскоязычной поэзии в контексте калмыцкой литературы и общероссийского литературного процесса в целом;

- определить периодизацию русскоязычной литературы Калмыкии;

- исследовать проблемы национальной идентичности и межкультурного диалога в русскоязычной поэзии Калмыкии в аспекте особенностей раскрытия авторского «я»;

- $\quad$ выявить коррелятивную связь творчества русскоязычных поэтов с этнонациональными традициями и культурными кодами;

- $\quad$ исследовать степень воплощения национальной специфики, передаваемой средствами русского языка в символических образах и поэтических концептах;

- $\quad$ определить особенности поэтики творчества русскоязычных калмыцких поэтов, выделить их национально-специфические черты.

Основными методами исследования явился комплекс взаимодополнительных принципов и приемов литературоведческого анализа: культурно-исторический, сравнительно-типологический. 
Степень изученности темы. В настоящее время нет специальных исследований, посвященных данному литературному явлению. Существует несколько работ, в которых рассматривается творчество отдельных русскоязычных поэтов.

Так, ряд вопросов, входящих в тематику нашего исследования, был затронут и получил соответствующее отражение в статье А. Г. Салдусовой «Современная русскоязычная поэзия Калмыкии» (2003), рассматривающей некоторые особенности развития калмыцкой национальной поэзии на русском языке, а также в статье поэта и исследователя Р. М. Ханиновой «Фольклор в лирике Джангра Насунова» (2013), освещающей связь произведений Д. Насунова с фольклорно-эпической традицией. Эти вопросы в той или иной степени рассматриваются во многих работах, посвященных творчеству самой Р. Ханиновой: Р. А. Джамбиновой «Кто станет символом поэта?» (1992), «Поэзия-исповедь» (1999), «Взлететь на Геликон» (1998); А. А. Бурыкина «Обретение идентичности» (О поэзии Риммы Ханиновой) (2005), «Грани таланта, грани времени...» (2002) и др., И. Б. Ничипорова «Эпическая традиция в современной калмыцкой поэзии: философские поэмы Риммы Ханиновой» (2004), ««Пастернаковский цикл» Риммы Ханиновой» (2005), «На перекрестках Софии и Веры...»: о новом поэтическом цикле Риммы Ханиновой (2003), «Час речи пробил»: философская поэма Риммы Ханиновой» (2004), «От афоризма к притче: поэтические циклы Риммы Ханиновой «В тени Конфуция» и «Ключи разума»» (2005) и мн. др.; А. А. Фокина «Заметки на полях необычной книги Риммы Ханиновой» (2005), «Поэзия диалога Риммы Ханиновой» (2011) и др.; Н. Ц. Манджиева «Жизнь - эстафета» (2004), «Взлететь над мира суетой» (1993) и др.; статьях Д. Б. Дорджиевой, В. Э. ОчирГоряева, К. А. Джушхиновой, В. В. Кукановой и др.

Отдельного внимания заслуживает первое учебное пособие «Современная русскоязычная поэзия Калмыкии» (коллектив авторов, отв. ред. Р. Ханинова, 2013), в котором исследуется современный литературный процесс и дан обзор жизни и творчества ведущих русскоязычных калмыцких поэтов Д. Насунова, В. Лиджие- 
вой и Р. Ханиновой. В пособии собраны разножанровые публикации: статьи, предисловия, заметки, рецензии, интервью разных лет, а также неизданные ранее материалы. Коллективный труд ученых, писателей, журналистов Москвы, Санкт-Петербурга, Калуги, Ростова-на-Дону, Элисты, Пловдива и др. дает определенное представление об основных тенденциях развития современной русскоязычной поэзии Калмыкии.

В плане научной разработанности обозначенной проблемы исследования следует отметить диссертационную работу Э. В. Лубинецкого «Своеобразие художественной речи в современной поэзии Калмыкии» (Москва, 2007). Основополагающим тезисом работы является утверждение о том, что национальное своеобразие творчества современных калмыцких русскоязычных поэтов (Г. Кукареки, Д. Насунова, В. Лиджиевой, Р. Ханиновой) просматривается на микроуровне в использовании традиционной народно-образной символики - «образов степи, коня, кургана, верблюда, сайгака, Будды», каждый из которых несет определенную смысловую нагрузку [Лубинецкий 2007: 12].

В целом обзор литературы показывает, что заявленная тема исследования отнесена к числу наименее разработанных. Упомянутые работы не дают ее полного исчерпывающего осмысления. В калмыцком литературоведении нет исследований, специально посвященных данной теме, нацеленных на выявление особенностей становления русскоязычной поэзии, основных тенденций развития, проблем национальной идентичности и т. д. Данное исследование является первой попыткой изучения проблемы развития современной русскоязычной поэзии Калмыкии.

Материалом для исследования послужило творчество калмыцких русскоязычных поэтов Калмыкии в аспекте проблем национальной идентичности и межкультурной коммуникации.

Теоретико-методологической основой исследовательской работы стали принципы и методы, разработанные в трудах ведущих исследователей современного литературного процесса: А. А. Потебни, М. М. Бахтина, В. М. Жирмунского, Ч. Г. Гусейнова, 
Г. Д. Гачева, Л. Н. Арутюнова, Д. С. Лихачева, Н. С. Надьярных, Ю. Я. Барабаш, К. К. Султанова, Е. Е. Балданмаксаровой, В. А. Бигуаа, 3. Г. Османовой, П. И. Тартаковского С. Л. Каганович и мн. др. Автор также опирается на достижения калмыцких литературоведов и критиков: Р. А. Джамбиновой, В. Д. Пюрвеева, А. Г. Салдусовой, научные воззрения языковедов, фольклористов, этнографов, буддологов А. Ш. Кичикова, Г. Ц. Пюрбеева, Э. У. Омакаевой, Н. Ц. Биткеева, Э. П. Бакаевой, Б. А. Бичеева, Т. Г. Басанговой (Борджановой), С. Г. Батыревой и др. Учтены результаты исследований российских ученых, таких как А. А. Бурыкин, И. Б. Ничипоров, А. А. Фокин и др., посвященных творчеству современных русскоязычных поэтов Калмыкии.

Труды названных ученых имеют большое значение для формирования методологической основы нашего исследования, помогают в определении основных особенностей и закономерностей развития калмыцкой литературы в целом и русскоязычной в частности.

Научная новизна работы заключается в том, что в калмыцком литературоведении впервые предпринята попытка специального исследования одной из малоразработанных проблем - проблемы формирования и развития современной калмыцкой русскоязычной поэзии как особого историко-литературного и художественного явления, определение ее национальных истоков с применением системно-ценностного анализа творчества русскоязычных поэтов республики. Вопрос определения художественно-эстетической ценности данного явления в аспекте национально-стилевой самобытности, высвечивающей национальную картину мира, также рассматривается впервые. 


\section{ГЛАВА І.}

\section{ЭТНОНАЦИОНАЛЬНАЯ ИДЕНТИЧНОСТЬ КАК ОСНОВНАЯ ТЕНДЕНЦИЯ ФОРМИРОВАНИЯ И РАЗВИТИЯ РУССКОЯЗЫЧНОЙ ЛИТЕРАТУРЫ КАЛМЫКИИ}

\section{1. Становление русскоязычной литературы Калмыкии в 1920-1930-е гг.}

Русскоязычное творчество национальных писателей отражает объективные процессы литературного развития, является одной из актуальных проблем современного литературоведения. Это вполне объективная, правомерная реальность, учитывая специфическую языковую ситуацию, продолжительное контактирование калмыцкой и русской языковых систем в Калмыкии. При этом предпочтение в настоящее время отдается русскому языку, которым многие калмыки, преимущественно среднего и младшего возраста, владеют значительно лучше, чем калмыцким. Более того, в настоящее время практически отсутствуют представители этноса, владеющие исключительно национальным языком. Причин, объясняющих сложное положение калмыцкого языка и важную общественную функцию русского языка, несколько. Сложившуюся дисгармонию исследователи объясняют «невостребованностью калмыцкого языка социальной средой, условиями реальной жизни, отсутствием мотивации у носителей общения на родном языке...» [Намруева 2008: 46]. При этом отмечается, что «носители калмыцкого языка в силу объективных и субъективных причин уже не испытывают потребность продолжать традицию общения на калмыцком языке, вполне удовлетворяясь русским языком, который обслуживает все коммуникативные потребности» [Намруева 2008: 46].

Относительно сложившейся ситуации исследователь Л. Б. Четырова отмечает, что «мы имеем дело с новым этническим феноменом - сохранением этноса в условиях, когда его представители не являются в полной мере носителями родного 
языка» [Четырова 2002: 67]. Как отмечают исследователи, связь между национальной идентичностью и языком не принципиальна. По мнению калмыцкого исследователя Б.А. Бичеева, помимо языка фактором национальной идентичности является «историческая память, обращенная к прошлому, и традиция... мера и природа изменений которой зависит от состояния сохранности того комплекса коллективной идентичности, который включает в себя как реальные, так и мифологические события своего исторического прошлого» [Бичеев 2003: 3]. Сюда входят и представления о родной земле, миф об общих предках, национальный характер, мировоззренческие обрядовые традиции, народное и профессиональное искусство, а также самая главная черта традиционной культуры, которую можно условно обозначить как буддийский культурный комплекс.

Языковая ситуация в Калмыкии не могла не повлиять на развитие литературного процесса в целом. Вместе с тем в современном литературоведении в силу целого ряда объективных причин остаются неразрешенными проблемы, связанные с рассматриваемым явлением. По справедливому утверждению поэта и одновременно исследователя Р. М. Ханиновой, явление русскоязычного творчества находится вне периферии внимания калмыковедения в силу ряда причин: «Во-первых, в советское время национальная литература, как правило, определялась принадлежностью авторов к родному языку, созданием произведений на языке титульных наций. Во-вторых, во многом равнодушное отношение к русскоязычным писателям различных республик было продиктовано отчасти и национальной политикой в области литературы и искусства, призванной демонстрировать достижения многонациональной России, отсюда и пресловутые «генералы от литературы» малых и больших республик СССР, избирательно представлявшие «ум, честь и совесть» народов. В-третьих, традиционно приоритетным было изучение национальной классики, литературных «маршалов», «генералов» и «полковников», «секретарской» литературы. Наконец, русскоязычная литература в 
республиках представлялась иным литературоведам и критикам чем-то вторичным, вненациональным, немощным в силу незнания или недостаточного владения родным языком ее авторами. При этом игнорировалась аксиома, что дух, душа народа могут отражаться и средствами иного, неродного языка» [Ханинова 2012: 3].

Между тем русскоязычное творчество - вполне закономерное, объективное явление, одной из главнейших характеристик которого является «коммуникативный аспект» [Подобрий 2009: 82]. Он заключает в себе плодотворное творческое взаимодействие, взаимовлияние, диалог национальных культур и литератур. «Ни одна литература не может существовать в одноязычном континууме, она живет и развивается только при наличии возможности перевода на другие языки или возможности писать на другом языке...» [Бурыкин 2010: 711]. «Обращение к подобному диалогу разных национальных культур в рамках русского языка и литературной традиции ведет не к «порабощению» одной культуры другой, а к их «сотрудничеству», коммуникации между собой и читателями разных национальностей» [Подобрий 2009: 82].

Традиция русскоязычного художественного творчества в Калмыкии берет начало в 1920-1930-е гг., когда закладывались основы многонационального литературного развития и в силу исторической необходимости на этапе становления находилось русско-калмыцкое двуязычие, возникшее и прочно впоследствии вошедшее в культурную жизнь калмыцкого народа.

Периоды, взятые для изучения развития калмыцкой русскоязычной литературы: 1920-1930-е гг., конец 1960-1980-е гг. и 1990-2000-е гг. - обусловлены общественным развитием и эволюцией эстетических идеалов калмыцкого этноса. Формирование и развитие калмыцкой русскоязычной художественной литературы в 1920-1930-е гг., в эпоху строительства советской власти, полностью отражает как историко-социальный, нравственный опыт калмыцкого народа, так и социолингвистическое развитие общества того времени, связанное с общественной функцией русского 
языка и его уверенным вхождением в культурную жизнь калмыцкого народа.

Несмотря на то что создавались все необходимые условия для развития калмыцкого литературного языка и национальной культуры: издавалась учебная литература, сборники статей по методике преподавания калмыцкого языка, велась подготовка кадров для преподавания родного языка и литературы, переводились на родной язык общественно-политические материалы, учебно-педагогическая, медицинская и художественная литературы, - русский язык становился языком межнационального общения и активно распространялся среди калмыков. Постепенное усиление его позиций именно в 1920-е гг. было обусловлено социалистическим укладом жизни, диктовалось просветительскими, общественными преобразованиями, а также «наступлением на неграмотность, характерным для первых лет Советской власти» [Есенова 2003: 16]. Создавались все условия для изучения русского языка как языка межнационального общения.

Постепенно русский язык стал языком не только межнационального, но и межлитературного общения. Русскоязычная литература в это время стала воплощением качественно нового типа эстетической общности, идейного, творческого и организационного единства национальных литератур. Отсюда «всесоюзный, интернациональный характер культуры, представлявший собой небывалую категорию художественного сознания, в котором воплощен интеллектуальный и эстетический потенциал многих наций и народностей» [Гамзатов 2008: 11].

1920-1930-е гг. в калмыцкой литературе - время первых литературных шагов таких поэтов и писателей, как А. Амур-Санан (1888-1938), Н. Манджиев (1905-1936), С. Каляев (1905-1985), Б. Басангов (1911-1944), А. Сусеев (1905-1995), Х. Сян-Белгин (1909-1980) и др. Все молодые таланты, пришедшие в калмыцкую литературу в этот период, своими учителями считали русских писателей: М. Горького, А. Серафимовича, Д. Бедного, В. Маяковского и других, чьи произведения несли ярко выраженную полити- 
ческую направленность и затрагивали историко-революционную проблематику. Знакомство с русской литературой способствовало расширению эстетического мышления и мировоззрения калмыцких писателей, подвигало их на освоение новых лексических пластов.

Как свидетельствует хроника литературной жизни Калмыкии, в 1920-1930-е гг. преимущественное внимание в литературе уделялось переводу на калмыцкий язык русской классики. Важную роль в расширении переводческой деятельности сыграл Первый Всесоюзный съезд писателей (1934 г.), впервые объединивший всех писателей страны в одну профессиональную организацию Союз писателей СССР.

Художественная переводная литература в Калмыкии возникла одновременно с профессиональной и стала частью общей национальной литературы. Наряду с собственными произведениями калмыцкие писатели и поэты (Г. Даваев, Х. Сян-Белгин, Л. Инджиев, П. Джидлеев, Г. Даваев и др.) начали публиковать первые переводы с русского на калмыцкий язык, ставшие для них школой мастерства, «существенным подспорьем в формировании реализма в калмыцком искусстве и литературе» [Пюрвеев 2001: 135].

Особенно значимым событием в культурной жизни республики стал перевод четырех песен калмыцкого героического эпоса «Джангар» на русский язык, предпринятый в конце 1930-х гг. С. А. Козиным. Текст этого перевода был издан в 1940 г. накануне празднования 500-летнего юбилея эпоса и сыграл немалую роль в популяризации калмыцкой культуры. В том же году в свет вышел «Джангар» в переводе С. И. Липкина с иллюстрациями В. А. Фаворского, что также стало важным событием для калмыцкой культуры и литературы.

Первые переводческие опыты калмыцких писателей характеризовались тем, что в текст привносилось много субъективного, редко учитывались стилевые особенности произведения, тем не менее общее значение первых опытов велико. Во-первых, они ознакомили калмыцкого читателя с классическими произведениями 
художественной литературы других народов; во-вторых, для калмыцких писателей художественный перевод явился своеобразной школой в освоении новых жанров, художественных систем, в совершенствовании писательского мастерства.

Говоря об освоении калмыцкими писателями многонационального художественного опыта, исследователи замечают, что оно носило поступательный характер. «Отдельные писатели как бы «боялись», что калмыцкая литература может потерять свое национальное своеобразие. Поэтому, возвращаясь к народно-поэтическим традициям, они замыкались в рамках фольклорной поэтики» [Пюрвеев 2001: 135]. Однако со временем реалистические традиции русской литературы, ее высокая идейность, народность, накопленные приемы мастерства помогли калмыцкой литературе выйти за пределы эстетики фольклора. Ведущей тенденцией становится «изображение внутреннего мира человека, стремление изобразить жизнь народа с исторической и психологической достоверностью» [Пюрвеев 2001: 136]. При этом решающую роль в формировании и развитии калмыцкой литературы сыграла, разумеется, сама действительность, требовательно стимулирующая, определяющая и направляющая это развитие. Художественноэстетический опыт мировой и русской литератур дал молодым калмыцким писателям новую направленность в изображении действительности, способствовал формированию собственной реалистической манеры.

Антон Мудренович Амур-Санан (1888-1938) считается основоположником русскоязычного художественного творчества Калмыкии. Являясь знаковой фигурой в истории и культуре республики - известный писатель, публицист, видный общественный деятель, - он сыграл важную роль в становлении калмыцкой литературы, обозначив совершенно новый этап в ее развитии. Его творчество - яркий пример взаимовлияния калмыцкой и русской литератур, обогащение литературы новым качеством в 1920-е гг. (идеологизация, реалистическое изображение мира и человека, отображение новой общественной действительности). С именем 
писателя связано зарождение калмыцкой русскоязычной прозы, утверждение в ней метода социалистического реализма.

Все его произведения, и роман «Мудрешкин сын» в частности, были написаны на русском языке и потому не были знакомы широкому кругу калмыцких читателей. Огромную роль в становлении А. Амур-Санана как писателя сыграло знакомство с русской классической литературой, общение с такими мастерами слова, как А. Горький, Д. Бедный, А. Сурков и др. Во многом определяющим русскоязычие писателя фактором послужили и годы учебы в университете в Москве, а также государственная и общественная деятельность, связанная со строительством социализма в Калмыкии (активный организатор советской власти в Калмыцкой степи и на Ставрополье, член Ставропольского губисполкома и коммисариата земледелия, заведующий отдела юстиции исполкома Сoвета депутатов трудового калмыцкого народа, заведующий Калмыцким отделом при Наркомнаце, член ЦИК СССР от Калмыкии, член КПСС).

Автобиографический роман-хроника «Мудрешкин сын» занимает особое место в калмыцкой литературе как одно из первых художественных прозаических произведений, написанных на русском языке. Как отмечают исследователи, этот роман стал ярким свидетельством того, что калмыцкий писатель может создать национально-своеобразное, хорошо принятое всесоюзным читателем произведение. Русский язык явился для Амур-Санана тем инструментом, благодаря которому он смог не просто раскрыть свой замысел, но и выйти за пределы ограниченного языковым барьером пространства, сделать книгу достоянием всесоюзной читательской аудитории, увеличив тем самым возможности региональной литературы.

Общеизвестная история создания романа представляет большой интерес не просто как литературный факт, она отражает путь писателя к русскоязычному творчеству.

Вначале, как отмечает Т. С. Есенова, Амур-Санан пробовал диктовать воспоминания своей жене К. В. Гавриловой, но остался 
недоволен результатом, так как в тексте не передавалась калмыцкая специфика. В 1922 г., находясь на лечении в Крыму, Амур-Санан продиктовал воспоминания о своей жизни писателю А. Хирьякову (А. Сакмадову), опубликовавшему их в своей литературной обработке в 1924 г. под названием «Человек, которого зовут Антоном». Книга именовалась «завещанием-автобиографией». Спустя год, выздоровевший Амур-Санан, переработав и дополнив свои воспоминания, переиздает их как полноправный автор в форме романахроники под названием «Мудрешкин сын». Это первое крупное прозаическое произведение, написанное на русском языке, стало ярким и убедительным свидетельством растущей художественной зрелости калмыцкой литературы. Писателю требовалось впитать и учесть романный опыт многонациональной советской литературы, в первую очередь — русского советского романа, имеющего богатые традиции.

Жанр романа-хроники, естественно, имел для автора свои преимущества, так как позволял наиболее полно и объективно изложить события, рассказать о пережитом, воссоздать картины обветшалого патриархально-феодального калмыцкого общества, показать его приобщение к новой жизни, к «битве за прекрасное будущее». При этом весь исторический материал показан через судьбу одного человека - самого автора, через его позицию и мироощущение. Предметом художественного интереса явились исторические изменения в жизни родного народа, тема народного протеста за свободу личности, борьбы против социального неравенства.

Роман «Мудрешкин сын» - одно из первых произведений, дошедших до широкого круга читателей. В калмыцкой литературе он стал вехой в процессе формирования романа как жанра. Автор сумел создать национальную энциклопедию жизни своего народа, а также выразить «кровную связь» с ним. Роман стал, как отмечается, одним из ярких проявлений «разомкнутости», расширения сферы национальной художественности [Джамбинова 2003: 7], примером взаимодействия с инонациональной культурой и реалистической литературой. 
Картина становления русскоязычного художественного творчества в калмыцкой литературе не может быть представлена без учета ее развития в условиях эмиграции. Это неисследованный пласт в калмыцком литературном процессе. Яркий представитель литературной диаспоры - Санжи Басанович Балыков (1894-1943). Русскоязычие писателя обусловлено его биографией. С. Балыков родился в 1894 г. в Задонской степи Сальского округа Области войска Донского в семье табунщика. Жизнь в казачье-русско-калмыцкой среде позволила ему рано овладеть русским языком. Кроме того, он учился в приходской школе, где, хотя и преподавались отдельные предметы на родном языке, в целом обучение велось на русском языке. В 1909 г. Балыков поступил в Великокняжеское высшее училище, по окончании которого получил звание народного учителя.

В 1914 г. в связи с началом Гражданской войны С. Балыков поступил в Новочеркасское военное училище. Впоследствии он участвовал в боевых действиях, получил звание офицера, был награжден Георгиевским крестом, орденом Святой Анны IV степени и орденом Святого Станислава. В 1919 г. вместе со своим полком Балыков эмигрировал в Турцию. Эмигрантская жизнь началась после отъезда из Турции в Болгарию и другие страны. С 1925 г. писатель работает в редакции калмыцкого журнала «Хонхо», издававшегося на «тодо бичиг» - старокалмыцкой письменности. В 1930-1938 гг. он является соредактором журнала «Ковыльные волны», созданным для калмыцкой диаспоры, проживающей в Европе, сотрудничает в таких эмигрантских изданиях, как «Единство и независимость», «Казачий сполох», «Вольное казачество». На страницах этих журналов Балыков публикует свои рассказы, очерки, а также публицистические статьи: «Попытка национального возрождения», «О национальной государственности», «Казачья художественная литература» и др.

Примечательно, что, выбрав русский язык как основной для художественного творчества, Балыков писал и на калмыцком языке. «Будучи билингвиальным, он одинаково легко и свободно 
писал и по-русски, и по-калмыцки», - подчеркивает профессор А. Борманжинов, «невольно» сравнивая его с писателем В. Набоковым. Русскоязычие С. Балыкова не разрушает представление о нем как о калмыцком писателе, а лишь придает многообразие и своеобразие творческой индивидуальности автора.

Несомненно, что С. Балыков не только талантливый писатель, но и разносторонне одаренная личность. Он осуществлял переводы с калмыцкого на русский и с русского на калмыцкий, плодотворно работал в области журналистики, был ярким публицистом, причем писал преимущественно на русском языке.

Как писатель С. Балыков реализовал себя в разных жанрах литературы. К сожалению, многие произведения, созданные как до, так и в период эмиграции, утеряны, и потому неизвестны даты написания произведений, их судьба. Некоторые рукописи, находящиеся в личных архивах родственников писателя, до сих пор не изданы. В Калмыкии благодаря усилиям народного поэта Е. Буджалова переизданы лишь две его книги: сборник рассказов «Сильнее власти» (Мюнхен, 1976), повесть «Девичья честь» (Мюнхен, 1983; Элиста, 1993), вызвавшая неподдельный читательский интерес, и сборник рассказов «Воспоминания о Зюнгарском полку» (Прага, 1927; Элиста, 1993), отражающих воспоминания самого писателя (как участника) о событиях Гражданской войны 1918-1920 гг.

По мнению литературоведа Р. А. Джамбиновой, «в рассказах С. Балыкова этнографические реалии - это только обрамление, национальный мир представлен гораздо глубже - в образе мышления, приметах национального характера, его мировосприятия» [Джамбинова 2003: 232]. «Национальное закодировано в образе его мышления» [Джамбинова 2007: 152-153]. К особенностям творческой манеры прозаика относятся фактологическая детализация, реалистичность, историзм, единение драматизма и обыденности происходящего. Основа его творчества - правда жизни, он не сочинял на отвлеченные темы. Темы, сюжеты, образы писатель черпал прямо из жизни. 
А. Борманжинов в очерке о жизни и творчестве писателя отмечал, что С. Балыков «без всякого сомнения, был в высшей степени удачным анналистом (летописцем) и художником-портретистом нравов и обычаев, превалировавших в то время среди донских калмыков» [Борманжинов 1993: 277]. Красочное описание художником «всех аспектов уклада жизни его сородичей», представляющее «значительный исторический и этнографический интерес и значение» [Балыков 1993: 277] мы наблюдаем в повести «Девичья честь», которая написана в эмиграции и датирована 1938 г. Это жесткое, лаконичное повествование о лично пережитом, произведение, в котором широко и убедительно показаны события Гражданской войны. Главным в повести также является создание полноценного художественного характера современника и жизненных коллизий, исторических обстоятельств, создавших этот характер.

Повесть «Девичья честь», а также сборник «Воспоминания о Зюнгарском полку», «разрушая стереотипы и ломая штампы, привносят свое видение событий Гражданской войны, трагедия которой состоит в том, что она развела по разным баррикадам один народ, один этнос» [Джамбинова 2006: 151]. При этом противоречивость эпохи выражена посредством передачи глубины сложных человеческих отношений. На примере драматической, а порой трагической судьбы своих героев (Бадни Цагакова, Зиндми Абушиновой, Цецени Кермековой и др.), их родных и близких писатель ярко показал перипетии жизни человека на изломе истории. От описательности темы войны, свойственной многим авторам, писателю удалось перейти к художественному осмыслению и обобщению реальных фактов и эпизодов.

Правдоподобие, максимально реальное изображение событий - характерная особенность художественного почерка С. Балыкова. Отсюда так трагичны в повести картины террора и неоправданной жестокости гражданской войны, мародерства и насилия «безумных фанатиков коммунизма» (С. Балыков) над мирным населением, над своими же братьями и сестрами. А. Борманжи- 
нов, высоко оценивая одаренного писателя, подчеркивал, что в его повествовании «нет ничего выдуманного, преувеличенного или преуменьшенного» [Балыков 1993: 278]. Можно отметить такие произведения на исторические темы, как «Отцы», «Четыре встречи», «Рассказ женщин-калмычек» и другие, также раскрывающие талант Балыкова.

Как уже отмечалось, повесть «Девичья честь» имеет глубокий этнографический контекст. Художественно исследуя национальное своеобразие и специфику векового уклада жизни калмыков, писатель уделяет немалое внимание точному, детальному воспроизведению народных традиций, обрядов и обычаев. Это не только придает повествованию этнографическую окрашенность, но и нередко становится конструктивным фактором в сюжетно-композиционной структуре произведения, художественно его обогащает, детализирует и делает зримым описание жизни и быта калмыцкого народа (описание скачек в Чепраке, игр «в кольцо», «в жгут», посещение хурула Пюрвей и Дамбой, указания ламы, описание примет, связанных с поведением животных, в частности верблюда, и т.д.). Особенно подробен и интересен рассказ о свадебном обряде.

Надо сказать, что интерес к национальным истокам, к глубинам духовного наследия своего народа, безусловно, определен условиями, в которых формировался писатель. Санжи Балыков рос в семье, где строго соблюдались обычаи и традиции, высоко чтились нравственные принципы народной морали. Поэтому лучшие страницы повести, посвященные традиционному образу жизни калмыцкого народа, не только эффектны, но и правдивы, что обогащает реалистическую ткань произведения.

Все литературные произведения писателя представляют определенный интерес для исследователей, как литературоведов, так и историков. Они отражают вклад калмыцкой зарубежной диаспоры в сохранение и развитие этнодуховной культуры калмыков, формирование нового качества национального самосознания. Литературное зарубежье, представленное в данном случае творчеством С. Балыкова, - особый пласт национальной культуры, оно пока- 
зало духовную силу нации, которая сумела, находясь в совершенно чужой этнокультурной среде, сохранить себя. В художественной форме писатель отразил уклад жизни калмыцкого народа, его традиции, обычаи, сложный исторический опыт (сборник «Сильнее власти», повесть «Девичья честь»). Писатель подчеркнул все достоинство народного морального кодекса, в котором отразились вечные общечеловеческие ценности: приверженность добру, святость семейных уз, почтение к родителям.

Находясь в изгнании более двадцати двух лет, С. Балыков на русском языке сквозь призму народного воззрения, собственно калмыцкого мироощущения и ментальности, сказал свое слово об уникальности этноса, художественно воссоздал национальную действительность такой, какая она есть, и в описании народных нравственных воззрений, и в отражении своеобразия этнической психологии калмыцкого народа, и в описании уклада жизни своих сородичей, сохраняя при этом особенности национального художественного мышления.

Как отмечают исследователи, изучение калмыцкого литературного зарубежья сегодня - необходимое звено для выработки новой концепции литературного развития Калмыкии, связанной с новым художественным мышлением, новым взглядом на историю национальных литератур. Эта область калмыцкого литературоведения ждет своих исследователей.

Рассматривая особенности становлении русскоязычного художественного творчества Калмыкии в 1920-1930-е гг., можно заметить, что оно было непосредственно связано с формированием межнациональных тенденций в развитии художественных традиций национальных литератур, доминированием интернационального. Для калмыцкой литературы данный период - этап «ученичества», закладывания основных направлений развития литературно-художественной мысли, связанной с идейно-художественным освоением действительности, усилением интереса к созданию положительного героя. Так, например, русскоязычные произведения А. Амур-Санана показывают приверженность авто- 
ра социально-исторической тематике и, как следствие, художественному конфликту, заданному бинарной оппозицией «прошлое - настоящее», «патриархальное - новое», проецирующейся на систему персонажей и композиционную структуру текста.

А. Амур-Санан и С. Балыков - два абсолютно разных писателя. Если в творчестве первого описание традиций и обычаев носит, скорее, иллюстративный характер, то в творчестве второго оно глубоко связано с литературным замыслом произведений. Испытывая чувство «потерянного дома», находясь за «железным занавесом», в своих произведениях автор запечатлел то, что ему было дорого, близко, писал о чувствах, боли утраты, переживаниях, незримой связи с исторической родиной.

Обращение национальных писателей (А. Амур-Санана и С. Балыкова) к русскому языку в первой половине XX в., желание создавать эстетические ценности на русском языке было продиктовано пониманием его неисчерпаемого богатства, интернационализацией образа жизни народа, использованием возможности выхода к всесоюзному читателю, а также связано с формированием межнациональных тенденций в развитии художественных традиций в 1920-х гг. Кроме того, обращение писателей к русскому языку было во многом связано и со сложившимися социальноисторическими и социолингвистическими условиями. В целом же русскоязычное художественное творчество Калмыкии стало ярким примером того, как важно для литературы преодоление «национальной замкнутости», а также взаимодействие с инонациональной литературой, в частности с русской, с ее многовековыми традициями.

\section{2. Развитие русскоязычной литературы Калмыкии в конце 1960-х - 1980-е гг.}

Рамки второго этапа развития калмыцкой русскоязычной литературы, конец 1960-х - 1980-е гг., связаны как с развитием межкультурного диалога, межнациональных связей и взаимоза- 
висимостей в литературе, так и с национально-возрожденческими процессами, реабилитацией калмыцкого народа. Именно в этот период велась сознательная и целенаправленная политика по национальному возрождению, что совпало с появившейся в обществе потребностью обращения к культурному наследию своего народа.

В литературе в это время происходит большой творческий подъем, создается целый ряд произведений исключительно на родном языке.

Для калмыцкой поэзии этого периода характерно обращение к лирическому познанию мира и связанному с ним психологическому реализму. Получает свое развитие философская лирика, что, несомненно, является свидетельством совершенствования культуры мысли, в истоках этой традиции - калмыцкий афористический фольклор и существующие в нем формы выражения философской мысли: двустишия, триады, четырехстишия. В творческой лаборатории калмыцких поэтов появляются такие стихотворные формы, как шестистишия, восьмистишия и двенадцатистрочники. Это доказывает, как тщательно работают поэты со словом, оформляя философские размышления. Обращение к таким формам говорит о том, что в поэзии родилась настоятельная потребность не только в живописании или выражении чувств, но и в некоем откровении.

Насильственное выселение народов в восточные районы страны, их унизительное положение в условиях спецпоселения, безусловно, привело к большим культурным потерям. Как известно, в отличие от ряда других народов, подвергшихся незаконному выселению, калмыки были лишены естественной возможности общения на родном языке вследствие целенаправленного дисперсного расселения людей небольшими группами по районам Сибири, Алтая, Средней Азии, Казахстана, Дальнего Востока. Кроме того, обучение детей спецпереселенцев в школах велось только на русском языке, что также осложнило бытование родного языка. «Языковую сферу не удалось восстановить и развить вплоть до настоящего времени» [Биткеева 2003: 162]. 
Приспособление к новым экстремальным обстоятельствам привело к тому, что функционирование родного языка, многовековых народных традиций и обычаев в период ссылки происходило у калмыков только на семейном уровне. Естественно, национальное самосознание испытало большое негативное воздействие.

В начале 1960-х гг., уже после восстановления калмыцкой автономии, наряду с национально-возрожденческим процессом в республике наблюдается расширение сферы применения русского языка: открытие школ, учебных заведений, обучение в которых велось на русском языке, увеличение числа книг, написанных на русском языке, и т. д. Нарушение естественной языковой среды в годы депортации, прочная позиция русского языка как языка межнационального общения привели к развитию калмыцко-русского двуязычия, что послужило одной из основных причин формирования литературы на русском языке в 1970-1980-е гг.

Развитие калмыцкого русскоязычного художественного творчества в этот период было связано с именами поэта Д. Насунова (1942-1979) и прозаика О. Манджиева (род. 1948). Оба автора принадлежат к поколению, рожденному и выросшему в Сибири, то есть практически вне родного языка, традиций и культуры, что явилось одним из последствий депортации.

Знание своих истоков, корней, ощущение кровного с ними единства как духовной высоты является отличительной чертой национальной поэзии того времени. Оно остро переживается авторами, у которых за плечами был опыт насильственной разлуки с родиной. Выросшие в Сибири, но воспитанные в семье согласно культурным традициям и обычаям родного народа, в своих произведениях они обращаются к истокам народной мудрости, духовному наследству и культуре этноса.

При этом они не ограничиваются введением в художественный контекст внешних атрибутов этничности: наименований, пояснений, образных выражений. Своеобразие их творчества - это глубинная и тесная взаимосвязь с культурой своего народа, плодотворное использование эстетики фольклора как органической части их произведений. 
Джангр (Виктор Иванович) Насунов (1942-1979) родился в Калмыцкой АССР. В 1943 г. семья Насуновых подверглась депортации в Сибирь. Его детство и школьные годы прошли в с. Черепаново Новосибирской области. В 1957 г. после восстановления автономии Калмыкии семья вернулась на родину (отец к тому времени умер). Пятнадцатилетний юноша был вынужден прервать учебу в школе, которую позже окончил заочно в г. Элисте, и устроиться разнорабочим. В 1968 г. он поступил в Литературный институт им. М. Горького, завершил обучение в 1974 г. Первая книга стихов «Голоса расстояний» вышла в 1971 г. Всего издано четыре сборника стихотворений Д. Насунова: «Голоса расстояний» (1971), «Поселенцы» (1977), «Полет копья» (1980), «Тамариск» (1982). (Подробнее о жизни и творчестве поэта в главе II.)

Национальное своеобразие поэзии Д. Насунова просматривается не просто в тематике и на микроуровне: в пейзажных зарисовках родной природы, в использовании традиционной народнообразной символики - образов степи, коня, верблюда, сайгака и т. д., являющихся внешним, материальным миром, окружавшим степняка-калмыка и формировавшим его художественное сознание, а в глубинном проникновении в его мироощущение. Мир лирического героя Д. Насунова неразрывно связан с традиционным образом жизни народа, поэт тонко улавливает и воссоздает реалии, из которых исторически сложилось бытие степняка, его жизненный кодекс, передаваемый из поколения в поколение. Именно поэтому можно сказать, что поэт не просто описывает этноментальность своего народа, он «органически живет» (К. К. Султанов) в ней, мыслит ее категориями («Здесь ты не встретишь броской красоты...», «Запах полыни», «А Маныч манит здешних и нездешних...», «Тишина», «Вдали ворчит рыдает Маныч...», «Джангарчи» и др.).

Так, в стихотворениях «Награда», «Памяти моего отца», «Трехлеток был горяч и необучен...» традиционный образ коня соотнесен с нравственными ценностями народа. Через инициационную символику автор выразительно передает не только значи- 
мость коня в жизни кочевника, их нерасторжимую связь. Обрядовое действо обретает в его произведениях качество нравственного урока, который лирический герой получил от отца-коневода: «Ты думаешь о том, чтоб не упасть,/ А не о том, чтоб укротить коня» [Насунов 1982: 29]. В этой фразе отражены и сила характера степняка, и глубина философского осмысления жизни: все существование человека заключается в созидании вечных ценностей, бесконечном завоевании неизвестного, в упорстве, преодолении невзгод и препятствий: «Сесть на коня - не сложная задача,/ Труднее удержаться на коне» [Насунов 1982: 29]. Эта мысль получила яркое поэтическое воплощение в образе коня и связанных с ним сюжетных коллизиях.

Стержень поэзии Д. Насунова - в мощном национальном начале, включающем в себя объем сознания и чувств, жизненный кодекс кочевника-скотовода, родившегося в свободной стихии степных просторов, в краю «неброской» первозданной природной красоты, бережно хранимой в душе степняка и являющейся для него духовной опорой на чужбине. Поэт вырос вне Калмыкии и потому особенно остро воспринимал свою связь с ней. Отсюда и «упрямая воля к обретению своей национальной идентификации, нашедшая выражение в образе тамариска» [Салдусова 2009: 510511], и присущая его лирическому герою жизненная мудрость и стойкость духа.

Писатель Олег Лиджиевич Манджиев родился в г. Новосибирске в 1949 г., куда была выслана его семья, подвергшаяся депортации. Окончил Литературный институт им. А. Горького в 1972 г. и высшие курсы сценаристов в Москве. С 1980 г. член Союза писателей СССР, позднее вступил в Союз кинематографистов. Является автором повестей и рассказов «Скачки» (1972), «Каникулы» (1973), «Мальчишка с бантиками» (совместно с Н. Нимбуевым) (1974), Острие копья» (1976), «День рождения» (1979), «И вечно возвращаться» (1983), «Амуланга» (1986), «Дорога в один дун» (1987), «Приключения Эльзятки в мышином государстве» (1991), «Судный день» (1992), романа «Ад номер семь» (2000). В 
1982 году вышел в свет сборник стихов О. Манджиева «Небесный родник».

Олег Лиджиевич - автор сценариев художественных фильмов, поставленных на киностудиях «Туркменфильм», «Мосфильм», «Казахфильм», на Рижской и Свердловской киностудиях. По его сценариям поставлены фильмы: «Вера и Зойка» (1983), «Амуланга» (1987), «Долина мести» (1987), «Сакман» (1987), «Бешеная» (1988), «Клятвы нашего детства» (1989), «Бегущая мишень» (1991), «И вечно возвращаться» (1993) и др. Широкое признание и любовь зрителей получил фильм «Гадание на бараньей лопатке», снятый по его сценарию в 1988 г. в Риге.

О. Манджиев - заслуженный деятель искусств Калмыкии, лауреат Государственной премии им. О. И. Городовикова, лауреат кинофестиваля «Большой кристалл» за сценарий к кинофильму «Гадание на бараньей лопатке», лауреат ряда международных премий в области кино. В настоящее время писатель живет и работает в г. Санкт-Петербурге.

В своих произведениях О. Манджиев неизменно обращается к теме нравственности, рассматривая ее в аспекте общечеловеческих и народных морально-этических норм. Значительное место в его прозе посвящено периоду ссылки.

Очевидно влияние на творчество писателя фольклорных традиций, структуры национального мышления и мировидения, картины мира, созданной народным знанием и опытом («Дорога в один дун», «Скачки», «Амуланга» и др.). Так, например, основная идея рассказа «Дорога в один дун» (1988 г.) - непреходящее значение в жизни современных людей устоев народного морально-этического кодекса (законов предков). Главная тема произведения - нравственное и философское становление, духовное перерождение молодых людей, оказавшихся перед лицом испытаний, только преодолев которые можно заслужить право называться настоящими людьми. В обществе, где угасают народные традиции, утрачивают свою незыблемость национальные основы бытия, важно услышать друг друга, а также прислушаться к го- 
лосу старших, хранителей национальной самобытности народа, не пренебрегая их напутствиями и советами. Эти мысли автора и определяют тематику произведения. Писатель говорит об исторической памяти, самосознании народа, экологических проблемах, неразрывно связанных с сохранением духовного потенциала людей. Олег Манджиев проповедует ценности, стоящие вне времени.

Герои его произведений проходят проверку на верность нравственным ценностям - общечеловеческим и этническим. «Оседлость» человека в семейно-родовой традиции, знание своих корней, истории своего народа, верность заветам предков - вот главная опора сохранения гармонии в мире, высокой нравственности в людях.

Национальная идентичность творчества и О. Манджиева, и Д. Насунова выражается, прежде всего, во взгляде на окружающий мир, в стремлении передать аксиологический ориентир своего народа, а также в преломлении самого материала, стилистических особенностях повествования. Средствами русского языка авторы смогли выразить все, что заложено в их генетической памяти: выразить внутреннее состояние этноса, присущее ему видение мира, не довольствуясь при этом поверхностным эффектом передачи национальной экзотики и национального колорита.

В их произведениях жива историческая и духовная память народа, общечеловеческие идеи и ценности проповедуются сквозь призму национального самосознания. Именно оно является основой философской картины мира.

\section{3. Развитие русскоязычной поэзии Калмыкии в 1990- 2000-е гг. (тенденции, тематический состав, жанровая система)}

Третий этап развития русскоязычной поэзии Калмыкии (1990-2000-е гг.) знаменован доминированием в художественном поэтическом творчестве русского языка. Предпочтение, которое отдавалось ему калмыцкими авторами, обусловлено как субъек- 
тивными факторами, так и объективными, возникшими в результате событий этнополитической истории, в первую очередь это последствия депортации. Несмотря на то, что в настоящее время огромное внимание в республике уделяется возрождению и развитию калмыцкого языка, повышению языкового самосознания народа, предпочтение во всех сферах отдается все же русскому языку, которым калмыки владеют в совершенстве. Родным же языком большинство владеет плохо или не владеет вообще. В подобных обстоятельствах калмыцкий язык в определении этнической идентификации имеет символическое значение.

Русский язык как язык образования, делового и непосредственного общения все более вытесняет национальный язык. И если, к примеру, в 1970-е гг., в период социально-исторических преобразований в республике, сознательной и целенаправленной политики по национальному возрождению, для Д. Насунова невладение калмыцким языком было одной из главных проблем и даже причиной душевных переживаний, то в 1990-е гг. для таких современных русскоязычных поэтов, как Р. Ханинова, В. Лиджиева, Б. Мунянова, этот вопрос не является существенным. Авторы осознанно выбирают в качестве инструмента творчества язык межнационального общения, руководствуясь при этом личными интересами, тенденциями развития общества и т. п.

В рассматриваемый период в современной калмыцкой литературе можно выделить три группы авторов. Первую сформировали поэты и писатели, пишущие только на родном языке: А. Джимбиев, Н. Бурулов, В. Нуров, В. Шуграева, Э. Эльдышев, Э. Тепкенкиев, Б. Васькаев и др. Вторую группу составили авторы, создающие произведения как на русском, так и на калмыцком языках: Н. Санджиев, В. Чонгонов и др. В третью группу вошли авторы представители титульной национальности, создающие свои произведения преимущественно на русском языке, языке свободного владения: О. Манджиев, Р. Ханинова, В. Лиджиева, Б. Мунянова, В. Папуев, Ц. Адучиев и др.

Параллельно с процессом развития русскоязычной литературы развивалась русская литература Калмыкии, которую представ- 
ляли поэты и писатели славянской национальности, пишущие на русском языке: Л. Петрова, Г. Кукарека, В. Прокопенко, Е. Пахомов, А. Соловьев, А. Скакунов, В. Лазарев, В. Хотлин, И. Гриньков, О. Чернышова, Н. Деева и др.

Э. В. Лубинецкий, автор диссертационной работы «Своеобразие художественной речи в современной поэзии Калмыкии», явления русскоязычной и русской литературы рассматривает в одном синонимическом ряду, исходя, по всей видимости, из того, что и та и другая развиваются на русском языке. По нашему мнению, русскоязычная литература и русская литература Калмыкии - понятия нетождественные, хотя творчество представителей русской литературы Калмыкии отнюдь не является совершенно вненациональным. Многим из них удается постичь особенности мироощущения калмыцкого народа. Они зачастую воссоздают в своем творчестве калмыцкий национальный колорит, используют жанры калмыцкого фольклора (в частности, йорялы - благопожелания), решают художественные, стилистические задачи, употребляя калмыцкие слова, этнографизмы и топонимы (как, например, Г. Г. Кукарека - украинец по национальности, пишущий на русском языке). Разграничивая русскую и русскоязычную литературу, можно брать во внимание не только этническую принадлежность, но и участие русскоязычных калмыцких авторов в переводческой деятельности. Так, В. Лиджиева занимается переводом произведений калмыцких авторов с родного языка на русский язык, Р. Ханинова переводит произведения отца М. Хонинова, а также других поэтов и писателей как с русского на калмыцкий, так и с калмыцкого на русский.

Бурятский литературовед Е. Е. Балданмаксарова в статье «Этнокультурная идентичность в современной бурятской литературе и межлитературный диалог: к постановке проблемы» отмечает, что поиск этнонациональной идентичности является «актуальной тенденцией бурятской литературы конца XX - начала XXI веков, отражающей один из самых значимых процессов, происходящих в исторической и культурной жизни общества» [Балданмаксарова 2011: 45]. Исследователь демонстрирует идею симфоничности 
национальной литературы, в частности многовековой литературы общемонгольского периода и общеевразийской и даже мировой составной литературного процесса и с этих позиций рассматривает развитие современной бурятской литературы. Балданмаксарова указывает на то, что в настоящее время, несмотря на «эпоху тотального Интернета, процесс глобализации, расширяющегося контекста, набирающей обороты интертекстуальности», бурятская литература ищет свое «лица не общее выражение», беря за базовую основу, как ценностный ориентир, проблематику этнокультурной самоидентификации [Балданмаксарова 2011: 17]. Однако, как считает исследователь, проведение однозначно разделительной грани «свой - чужой» было бы ошибочным: «В бурятской литературе, выпестованной из глубин этнического самосознания, проблема этнокультурной идентичности, как в ранний постсоветский период, не сводится к дилемме «мы - они», выдвигается такое имманентное качество идентичности, как интегративность, предполагающая внутреннюю множественность и диалог идентичностей. А это обнадеживает, ибо этнокультурный контекст, самобытность художественного миропонимания раскрывается наиболее полно в системе встречных культурных и литературных движений» [Балданмаксарова 2011: 47].

Таким образом, перед нами парадоксальность региональной литературы, которая, являясь частью общероссийской литературы, существует на значительных этапах своего развития как бы «внутри» этнической культуры и «наряду» с ней, в контексте евразийской культуры, а может, и шире. Мысль автора о создании целостной концепции истории бурятской литературы XX века, включающей в себя генезис, исследование истоков, причем в культурно-философском контексте истории монгольских народов, является вполне актуальной и для развития калмыцкой литературы. Статья Е. Е. Балданмаксаровой «Этнокультурная идентичность в современной бурятской литературе и межлитературный диалог: к постановке проблемы» содержит в себе методологическую основу для соответствующего направления исследований, призванных 
раскрыть закономерность «многообразия единства» литературы современной России.

Русскоязычная поэзия в указанный период представляет собой только формирующуюся эстетическую систему, но в то же время это довольно самобытное и оригинальное явление. Пришедшее в литературу новое поколение авторов принесло с собой «свой вкус слова, свое понимание мира и человека» [Салдусова 2009: 511]. Их появление и творческий рост, безусловно, обусловлен традициями, заложенными предыдущими поколениями поэтов: С. Каляевым, Л. Инджиевым, Х. Сян-Белгиным, Д. Кугультиновым, М. Хониновым, Б. Сангаджиевой, Е. Буджаловым [Салдусова 2009: 511]. Развиваясь параллельно с собственно национальной литературой, калмыцкая русскоязычная поэзия, с одной стороны, преемственно продолжала традиции национальной литературы предшествующих лет, а с другой, преодолевая рамки идеолого-эстетической обстановки советской эпохи, внесла новую струю, отличаясь существенными чертами: масштабностью тем, жанровым многообразием, усилением интереса некоторых авторов к собственным корням, национальной истории (в частности, к теме депортации), культуре, обычаям и традициям. В ней сосуществовали и взаимодействовали традиции и новаторство, национально-особенное и инонациональное.

Можно сказать, что в указанный период и в настоящее время задачи русскоязычной поэзии, как и всей калмыцкой литературы, в области поиска этнонациональной идентичности усложнились. Этот поиск происходит не только в пределах обозначения определенных элементов литературной традиции и выделении ключевых символических образов и концептов национального сознания, особенностей калмыцкой культуры. Обрести и сохранить этнонациональную идентичность стало необходимо на фоне выхода к межлитературной, межкультурной коммуникаци.

Масштабная, быстро набирающая силу глобализация информационного процесса, обрушившегося на сознание человека, жившего в относительно ограниченном мире с устоявшейся системой 
координат, требует от калмыцких русскоязычных поэтов освоения огромного материала, масштабного взгляда, осмысления всех происходящих в мире процессов. Перерабатывая уже сложившиеся формы и традиции, авторы ищут свое направление, имеют большой интеллектуальный потенциал, глубже знают современный литературный процесс. Поэты черпают силы из диалектической связи с современностью, из верности жизненной правде, при этом в их художественных произведениях неизменно присутствуют (по воле автора или независимо от нее) константы бытия, его фундаментальные свойства, вселенские и природные начала (универсалии), составляющие комплекс онтологических тем искусства. Названные и неназванные бытийные начала составляют многоплановый комплекс вечных тем.

Необходимо отметить такое свойство калмыцкой русскоязычной поэзии, как усвоение категорий постмодернистской поэтики, в частности интертекстуальности.

Интертекстуальность, как отмечают исследователи, является важнейшей смысло- и текстообразующей категорией постмодернистской поэтики. В настоящее время существуют различные формулировки данного термина.

Источником теории интертекстуальности стала концепция «диалогизированного сознания», или диалогичности текстов, разработанная известным отечественным ученым-филологом М. М. Бахтиным. Введенное Ю. Кристевой понятие «интертекстуальность» подразумевало включенность текста в смысловое поле большой культурной традиции. Н. А. Кузьминой данная категория понимается как «свойство любого текста вступать в диалог с другими текстами» [Кузьмина 2007: 19]. И. П. Смирнов рассматривает интертекстуальность как способность текста полностью или частично сформировать свой смысл [Смирнов 1985: 12]. Новый метод учитывает и ставит во главу угла «семантические трансформации, совершающиеся при переходе от текста к тексту и подчиненные некоему единому смысловому заданию» [Смирнов 1995: 11]. Текстообразующей категорией вторичного текста счи- 
тает интертекстуальность В. Чернявская, исследовавшая особенности научной коммуникации. Несмотря на различие подходов, во всех дефинициях присутствуют некоторые «инвариантные признаки: интертекстуальность - это маркированная определенными языковыми сигналами «перекличка» текстов, их диалог» [Кузьмина 2007: 20].

Интертекстуальность как литературный прием, возможности которого только сейчас начинают осмысляться в калмыцкой литературе, широко используется преимущественно в творчестве P. Ханиновой. Отсюда и главное отличительное свойство всего творчества этого автора - диалогичность. При этом, как верно отмечает А. Фокин, ее поэзия чужда вторичности, прозрачной цитатности, наивной интертекстуальности: «...каждой своей строкой она как бы признает над собой суд традиции, осознает, что пишет после ... после Ахматовой, Цветаевой, Мандельштама, Пастернака, Бродского...» [Фокин 2005: 179].

Подобные «переклички», очень плодотворные в творчестве Ханиновой, служат диалогичности текстов, «отсылая к другому тексту и/или замещая его» [Масленикова 1999: 252]. Благодаря насыщенности ханиновских текстов литературными реминисценциями, мы можем говорить о том, что ее поэзия рассчитана как на читателя-интеллектуала, который увлечен разгадыванием литературных ребусов, так и на массового читателя, которого интересует увлекательный сюжет. Круг авторов, которые становятся центрами интертекстуального «излучения», у Р. Ханиновой довольно широк. В ее произведениях мы находим целую россыпь многочисленных литературных цитат, эпиграфов, реминисценций, философских аллюзий. Это, в первую очередь, интертекстуальное растворение и диалог с отцом, выдающимся калмыцким поэтом и писателем М. В. Хониновым. Р. Ханинова прямо апеллирует к его стихам, разворачивая, как отмечают исследователи, заданные им темы, идеи и образы, творчески развивая их в своих стихотворениях. Также поэт вступает в поэтический диалог со знаменитыми философами прошлых веков, с поэтическими 
мирами художников русской и мировой литературы (А. Пушкиным, С. Есениным, В. Жуковским, А. Чеховым, М. Горьким, О. Мандельштамом, И. Бродским, Б. Пастернаком, М. Цветаевой, А. Ахматовой, А. Вознесенским, Д. Донном, В. Гюго, Д. Байроном, Ш. Бодлером, А. Рембо, Д. Алигьери и мн. др.). При этом, как отмечает А. Г. Салдусова, «реминисценции из мировой культуры, литературы в поэзии Р. Ханиновой формируют поэтику, где образ, мотив, стилистический прием рассчитаны на ассоциативное восприятие, что формирует облик нового героя, обладающего определенным объемом культурной памяти» [Салдусова 2009: 510-511].

Через призму интертекстуальности мир поэзии Ханиновой предстает как огромный текст, в котором что-то новое возможно по принципу «калейдоскопа», когда смешение определенных элементов того, что уже было сказано, дает новые комбинации. При этом интертекст никогда не является для Ханиновой буквальным повтором оригинального текста. Цитаты могут раскрываться ссылкой автора в тексте примечаний или комментария. Так, в сборнике «Взлететь над мира суетой» раздел «Автограф» практически полностью строится на диалоге с другими поэтами - предшественниками и современниками: на реминисценциях, аппликациях, аллюзиях, контаминациях. Произведения несут чисто интертекстуальный характер, рассчитанный на память и ассоциативное восприятие читателя.

Например, стихотворение «Есть в мире узы роковые...» отсылает к произведению Е. Растопчиной «И есть родство, родство святое...». «Вся жизнь - неразгаданный сюжет...» апеллирует с произведением А. Ремизова «Вся Россия - непредсказуемый сюжет». «Не пробежать, пройти б на цыпочках» несет в себе отзвук цветаевской идеи из стихотворения «Прокрасться», связанной с мыслями о преодолении плотского, материального начала, о бегстве, ускользании от материи и страстей в мир отрешенности и небытия для понимания надвременнных ценностей человеческого бытия. Первые строки стихотворения «Судьба», открывающее сборник «Зимний дождь», — «Так много пройдено дорог. / Так 
много сделано ошибок...» - имеет сходную синтаксическую и образно-смысловую структуру с есенинскими «Так мало пройдено дорог, / Так много сделано ошибок». Мини-цикл «О любви» восходит к контаминации ахматовских («Я научилась просто мудро жить..») и тютчевских («Мысль изреченная есть ложь») тезисов. Классические примеры ахматовской поэтической афористики напоминают критикам и некоторые произведения из цикла «Четверостишия» Риммы Ханиновой.

Диалог с традицией, основанный на осмыслении философских глубин древнейших пластов восточной (калмыцкой, китайской, арабской, японской) и европейской (греческой, скандинавской, немецкой) мифологии, содержится и в уже упомянутых циклах «Древние метаморфозы» и «Наследство». В этом ряду и цикл «Аксиомы», раскрывающий диалог калмыцкого поэта с французскими философами прошлых веков: с Ф. Ларошфуко («Максимы»), Б. Паскалем («Мысли»), Ж. Лабрюйером («Характеры») и др., и поэтический мини-цикл «После любви» (из сборника «День влюбленных»), построенный на соединении ахматовских и тютчевских тезисов, и поэма «Формула судьбы», где также много реминисценций (поэзия Д. Байрона и В. Гюго, сутры Корана, изречения Тамерлана, арабские пословицы), и полемика с А. Солженицыным в стихотворении «Обычай предков - сдержанность всех чувств...», и напоминание о А. Сумарокове и А. Пушкине в стихотворении «Все говорят: нет правды на земле...». Не являются исключением и циклы Р. Ханиновой, посвященные Б. Пастернаку, И. Бродскому, и многие другие.

В литературном процессе Калмыкии следует отметить и такое явление, как русификация калмыцкой русскоязычной литературы, выражаемая в сравнительном отмежевании авторов от национальной культуры. В результате в произведениях некоторых калмыцких поэтов национальная идея, национальное своеобразие практически отсутствуют. Так, в поэзии В. Лиджиевой, Ц. Адучиева и ряда других авторов практически не обнаруживаются характерные приметы национального стиля, которые бы пронизывали 
ткань произведения, определяя их многослойность и глубину, отсутствует осознанное отражение своих корней.

Проблема русификации калмыцкой русскоязычной поэзии, как и любое явление, может быть рассмотрено с разных сторон. С одной стороны, русификацию можно считать естественным и даже закономерным явлением, учитывая исторически сложившуюся этнолингвистическую ситуацию в республике, процессы языковой ассимиляции, при которых русский язык стал практически единственным языком общения, то есть родным. Кроме того, это явление демонстрирует и результаты набирающего силу процесса глобализации, связанного с масштабными социокультурными трансформациями.

С другой стороны, русификация калмыцкой русскоязычной поэзии - это, безусловно, свидетельство вырождения национального начала, о котором пишут некоторые авторы (к примеру, А. Эбаноидзе). Однако это тревожное обстоятельство, требующее к себе особого внимания, касается не всех представителей калмыцкой русскоязычной поэзии. Невозможно игнорировать глубинной национальной природы творчества таких калмыцких русскоязычных художников слова, как Д. Насунов, О. Манджиев, Р. Ханинова, для которых главным является все же сохранение этнических категорий. Авторы не ограничиваются внешними атрибутами, броскими деталями национального колорита, их этничность проявляется на более глубоком уровне - осознания исторического и культурного опыта народа, проникнутости его миропониманием. Их произведения отличаются максимальной полнотой художественного изображения национального характера. В них просматривается генетическая связь с художественным мышлением народа на уровне отражения взаимоотношений между частным и общим, между символом и жизнью.

Говоря о тематическом составе современной русскоязычной поэзии, следует заметить, что этнонациональная идентичность творчества авторов проявляется и через призму пространственно-временных координат. Круг кочевого пространства вбирает 
в себя определенный ряд концептов. Это степная стихия: степь, конь, трава, курган, сайгак и т. д. - так называемые «константы мировидения», архетипы пространства. Авторы не только создают образный строй своих стихотворений, раскрывают единство мира человека и мира природы во вселенском макрокосмосе, обладающее обобщающей силой, но и раскрывают национальную целостность, отражают психологию калмыцкого народа, его самобытное миропонимание, образ мыслей, традиционную систему взглядов, жизненную философию, традиции, обычаи. В их поэзии представлена образная модель мира, в которой комфортно кочевнику, неотделимая часть этого мира - родной очаг.

Одной из тем, несколько возвращающих поэтов к архаическим формам художественного мышления, становится тема родной земли, являющаяся доминирующей в калмыцкой национально-художественной картине мира. Внимание художников направлено, прежде всего, на восприятие бытия природы - одно из оснований, на которых выросло национальное мироощущение, менталитет калмыцкого народа, испокон века черпающего свое вдохновение из красоты окружающего мира.

Как известно, природа для кочевника - объект самоутверждения, реализации всех его помыслов, он ощущает себя ее частицей и словно сливается с ней. Об этом свидетельствуют обычаи, традиции, ритуалы, сохранившиеся у калмыков до сегодняшнего дня: поклонение небу и земле, почитание объектов природы - курганов, озер, рек и т. д. Органичная взаимосвязь и близость человека к миру природы определили особое «природное» мироощущение калмыцких поэтов, при этом одним из главных пространственных символов является традиционный образ степи.

Архетип степи представлен всеми авторами в тематическом контексте «Дом/Родина» и связан непосредственно со стихией Земли. И дело здесь не в том, как тот или иной поэт пишет о ней, а в том, какой импульс она дает их чувственно-мыслительному восприятию. 
Так, лирический герой поэтессы Б. Муняновой, оказавшись в степи, одновременно ощущает небо и землю, чутко улавливает движение времени, отчетливо чувствует струящийся в воздухе запах полыни, слышит стон земли от зноя. Картина степи в ее произведениях одухотворена: «степь готовится на свидание с любовником-ветром», «окропляя себя терпкой полынью с мятой», «расшивает тюльпанами свой стан», «объятый поясом трав», и т. д. Как пишет И. Ничипоров, в зеркале одушевленных пейзажных образов - степи, ветра, неба и небесных светил - раскрываются магия любовного заклинания («О луна, луна моя колдунья, / Верная наперсница души...»), многомерность поэтического чувства, насыщенного родовой причастностью к «крови кочевой»: [Ничипоров 2006: 290]. В произведениях Б. Муняновой приоритетна идея всеобщей гармонии, в основе которой лежит любовь к природе как родительнице всего живого на земле (например, «Лето в степи»). В поэтике стихотворений автора заложена «целостность степного мирочувствия, нерушимость вселенского покоя» [Ничипоров 2006: 290].

Идея единства времени-пространства человеческой жизни и природного мира во вселенском макрокосмосе звучит и в творчестве Р. Ханиновой. В предисловии к циклу «Взлететь над мира суетой» поэт раскрывает философский смысл, который она вкладывает в образ степи - смысл, связанный с идеей единства всего мироздания: «Степь. Ее не сразу разгадаешь. Она не откроется с первого взгляда. Она дарует знания не случайным. Ее необъяснимая природа обаяния в ваших генах. Сопротивляясь, недоумевая, вы с удивлением обнаруживаете со временем свою зависимость от терпкого запаха полыни, бескрайнего горизонта, обнажившего вас в степном пространстве: в своей первозданности. И тогда скромные, пастельные пейзажи будут бередить душу, взывая к давно забытым воспоминаниям. Ее простор, раздвигающий границы неба и земли, будит космическую память человека, ощущающего себя наедине с природой. Степь таит в себе секреты времени и пространства. Она величественна в вековом покое, даже потре- 
воженном вторжением человека» [Ханинова 1994: 89]. Здесь мы находим универсальный опыт наблюдения, который когда-то позволил предкам установить такие взаимоотношения с миром. Присутствие автора в тексте ощущается как точка зрения на сущее, которая выстраивает его «модель мира» [Гачев 1988: 47] и художественную реальность, к которой он приходит из колыбели древнего мировосприятия. Подобное восприятие мира вызывает однозначное приятие, поскольку принадлежит не одному человеку, а издревле закреплено в формах, выработанных народным сознанием. Такому взгляду на мир нельзя научиться, с этим можно только родиться, считая себя составной частью великой матери-природы. Живя в степных просторах, невозможно не ощущать родства с этим миром, не чувствовать себя частью этого космоса. Поэтому в поэзии Ханиновой лирический герой сроднился со степью, она для него часть жизни и принимает его в свои объятия как мать:

Плачь, сердце, степь - твоя праматерь -

в суровой доброте своей,

спасала не однажды.

не искать ли

в ее истоках

жизненный ручей... [Ханинова 1997: 32].

Употребление слова «праматерь» говорит о сакрализованном, одухотворенном отношении к природе как к высшему началу. Авторское мировосприятие формируется на основе мифопоэтических воззрений народа, согласно которым создается образ матери-степи, представляющей в национальном мировосприятии родительское начало (небо - отец, земля - мать). Мать - это и человек, давший жизнь, это и праматерь, прародительница, хранительница рода, очага, это и, в широком смысле, синоним слов «родина», «степь», «край». Все эти понятия неразделимы для любого калмыка. Желание поэта постичь тайны мироздания, проникнуть в сущность вещей проявляется в данном случае в тяге к такому смысловому ассоциативному ряду, как мать - прародительница - родина. Он связан с наделением степи высшим, главенствую- 
щим началом, воплощаемым в древнем образе «матери-прародительницы» и принимающим одновременно образ человека.

Персонифицирование родной земли с образом матери, как известно, является общераспространенным мотивом во многих культурах, при этом земля всегда обожествляется. Общеизвестно, что архетип «мать», выделяемый К. Юнгом, относится к числу самых основных и важнейших архетипов человечества. Во всех мировых религиях земля и небо осмысливаются как супружеская пара. По определению М. М. Бахтина: «...земля — это поглощающее начало (могила, чрево) и начало рождающее, возрождающее (материнское лоно)» [Бахтин 1986: 541].

В калмыцкой литературе поклонение степи и приятие ее как великого материнского первоначала доминирует в творчестве всех калмыцких художников слова. Они называют ее матерью и представляют в своих произведениях как живое, человекоподобное существо, активное действующее лицо, представляющее живой, контрастный, самоценный и гармоничный мир. Воссоздается движение ветра, света, звуков, которыми заполнено все пространство этого мира.

Образ степи неразрывно связан в калмыцкой поэзии, как и в народном восприятии, с ощущением свободы. В период возрождения национального самосознания после сибирской ссылки и в последующем эта взаимосвязь отражает, с одной стороны, то утоление жажды простора, которого так не хватало калмыкам на чужой земле, с другой - возвращает в поэзию древнее понятие о единстве Неба и Земли.

Многим произведениям калмыцких русскоязычных поэтов, посвященных степи, присущ гимнический характер. Степь в творческой лаборатории калмыцких русскоязычных поэтов - это не только картина внешней природы, пейзажная зарисовка, в которой поэтическим языком они отражают скромную, неброскую красоту родного края. В их произведениях образ степи по большей части получает философское звучание. Кроме того, он отражает своеобразную диалектику души народа, его традиционное мироощу- 
щение. Таким образом, обращение авторов к образу степи - не просто дань традиционной теме, а постоянная, непреходящая потребность в осмыслении сущности мира, художественный прием, позволяющий выразить свои идеалы, а также философско-эстетические принципы, размышления о тайнах вечности, гармоничности мира и человеческого бытия.

Говоря о тенденциях развития калмыцкой русскоязычной поэзии, можно заметить, что она насыщается емким жизненным содержанием, в ней возрастает роль аналитического начала, расширяется диапазон тематики.

Художественное пространство калмыцкой русскоязычной поэзии, вмещая в себя традиционные ключевые темы, коррелирует с качественно насущным, длящимся временем. Сквозь призму времени рассматриваются такие темы, как смысл жизни человека, его предназначение, рождение и смерть, тема быстротекущего времени, ответственность за каждый прожитый миг и т. д.

Тема, связанная с вопросом о смысле человеческой жизни, - одна из самых распространенных в калмыцкой русскоязычной поэзии. Смысл человеческого существования заключается для поэтов, во-первых, в детях (Р. Ханинова «Мой сын - начало всех начал», В. Лиджиева «Дочке....»), во-вторых, в любви к родителям (В. Лиджиева «Руки отца», Р. Ханинова «Подкова над отчим домом» и мн. др.). Для Р. Ханиновой благодарность и любовь к родителям связана также с сохранением преемственности в отношении к творческих принципов отца-поэта.

Смысл жизни заключается для всех калмыцких авторов и в творческом «ремесле»: «И не предаст, и не обманет, / и не простит - так повезло, — / моя напасть! мое богатство! / мое святое ремесло!») [Ханинова 1994: 117]; В. Лиджиева: «Все можно бросить...»: «Все можно бросить, ото всех сбежать, / И от всего отрешиться... / Только стихи не брошу писать. / Буду стихам молиться» [Лиджиева 1992: 12]. Рождение книг, например, для Риммы Ханиновой является «сотворенным чудом», «искомой мечтой», сравниваемо с любовью, с «первым поцелуем», «первыми шагами», с «беспо- 
мощными», но в то же время «дерзкими» и «отважными» детьми, вступившими «от порога» во взрослую жизнь. Поэт просит судьбу продлить «сей миг»:

Чтоб звездным был не час, не месяц, а звездопад - через всю жизнь.

Чтоб, вехи звездами отметив, звездою в жизни пронестись [Ханинова 1994: 114].

Следуя традициям русской литературы, калмыцкие поэты в своих стихотворениях тяготеют к философским раздумьям. В их творчество широко входят такие сложнейшие темы мировой философской лирики, как тема жизни и смерти, бренности человеческого существования. Лирика насыщается емким жизненным содержанием, в ней возрастает роль аналитического начала.

Исследование жизни, в которой прошлое переходит в будущее, а будущее в прошлое и современность ведет диалог с прошлым, также занимает важное место в идейно-тематическом содержании творческого материала калмыцкой русскоязычной поэзии. Это тематика связана, в частности, с обращением к событиям Великой Отечественной войны и депортации, оставившим тяжелый след в коллективной памяти народа. Обращение к данным темам - это не только обращение к прошлому. Здесь и ощущение эпохи в целом, и тема большого исторического пространства, и связь поколений.

В русскоязычной поэзии Калмыкии Великая Отечественная война для поэтов - не только тема или лейтмотив, но и угол поэтического зрения. И хотя поэты этого поколения не были ее непосредственными участниками, эхо тех суровых дней находит отклик в их творчестве. События войны воссоздаются через воспоминания отцов, дедов, матерей. Поэтому в стихотворениях нет военной конкретики. Идея большинства произведений - осознание подвига своего народа, необходимости сохранить и передать память о нем последующим поколениям.

В творчестве Р. Ханиновой тема Великой Отечественной войны представлена в художественном диалоге с отцом и определя- 
ется, прежде всего, биографическим фактором. М. В. Хонинов участник Великой Отечественной войны 1941-1945 гг., участник партизанского движения в Белоруссии. И хотя поэт Р. Ханинова родилась после войны, она не дистанцирована от нее, как сегодняшнее поколение, ведь рядом был отец - живая память, общение, воздействие. Страдания, связанные с событиями войны, она видит именно его глазами:

Война мне снилась памятью отца -

Повторным кадром юного лица, -

Во мне потом его строкой жива,

Легендой сохраненная молва... [Ханинова 1994: 98-99].

Р. Ханинова создает такую образную структуру, которая будит память о необходимости сильных людей, обладающих никогда не умирающей волей к жизни, свободе и борьбе за нее. Автор подчеркивает кровную связь лирического героя с отцом, воспроизводит качества, характер и философию бойца.

Осмысление такого тяжелого испытания в истории народа, как депортация и тринадцатилетняя сибирская ссылка, как в автобиографическом, так и в нравственно-идеологическом аспектах происходит в калмыцкой литературе начиная с конца 1960-х гг. К этой теме обращаются такие писатели, как М. Хонинов, Л. Инджиев, А. Бадмаев, А. Балакаев и др. В их произведениях не просто воспоминания о пережитых страданиях, неизбывной тоске по родине. Авторы также отражают трудный путь переосмысления идеологических приоритетов. Практически в творчестве каждого присутствует тема заблуждения в отношении вождя всех народов, отражающая эволюцию взглядов целого поколения (Д. Кугультинов «От правды я не отрекался», «Убийство в церкви», М. Хонинов «Мой путь», «Мои руки» и другие).

В современной русскоязычной поэзии Калмыкии тема депортации- это попытка художественно осмыслить свершившееся с точки зрения глобальных проблем прошлого и настоящего.

Страницы трагической истории подвигли Р. Ханинову на создание цикла «Сибирской памяти тетрадь» (1991) (подробнее см. 
в главе III). В произведении «Им снилась степь в раздолье ковыля...» особенно четко прослеживается философская, созерцательная направленность ее поэзии.

Степь для калмыка неотделима от его существования. Однако в условиях депортации привычная гармония нарушается, разрушая душу людей, ассоциируясь с мечтой о несбыточном. Стихотворение словно настояно на многолетнем потаенном страдании и непреходящей боли. Автор с горечью говорит о том, как без хозяина «рассыхается седло», мающееся давно без дела, на стенке «дедовская плеть», которой «без него теперь дано стареть...», и тринадцать лет лишь «зов вожака» «без седока» поднимает табун лошадей в степи. Р. Ханинова в своем стихотворении, опираясь на категориальные понятия духовной и исторической памяти, выражает своеобразную философию народной этики, духовной памяти. Помнить и верить означало для народа жить, традиция и память помогли народу выстоять и сохраниться.

Отец Р. Ханиновой, как и все калмыки - участники Великой Отечественной войны, был снят с передовой и оказался на положении спецпереселенца. Оклеветанный, униженный, он не изменил своему национальному кодексу и заветам предков, «был честным до конца», «жил, как в бою, и верил в торжество» социальной справедливости. В стихотворениях, посвященных депортации, неоднократно звучит мысль о необходимости таких людей - бескомпромиссных, отважных, знающих себе цену, верных отчизне и народу. И такого героя Р. Ханинова видит в своем отце. В его сердце нет ненависти и злобы. Он, как и весь калмыцкий народ, выстоял, не сломался, сохранил чистоту нравственных устоев. В одном из своих стихотворений (подробнее см. в главе III настоящего исследования) Р. Ханинова вступила в полемику с А. Солженицыным, который в романе «Архипелаг Гулаг» написал, что «калмыки не стояли - вымирали тоскливо...». На примере судьбы своего отца поэт говорит о мужестве, стойкости и высокой духовности всего калмыцкого народа.

Отмечая тенденции развития современной калмыцкой русскоязычной поэзии, нельзя не отметить и такую особенность, как 
интерес к духовному наследию своего народа, близость к устному народному творчеству. В поэтическом творчестве авторов прослеживаются обращения к народным сказкам, мифам, преданиям, и это не простое переложение фольклорного материала. Создаются полноценные, самостоятельные, лирические произведения, созданные на основе усвоения принципов фольклора, осознанного использования его изобразительных средств, стилеобразующих факторов.

Органическая близость фольклору - драгоценная черта творчества Р. Ханиновой. Она серьезно работает над изучением устного творчества народа, «снабжает свой текст комментариями к буддийским ламаистским реалиям, традициям и обычаям калмыков, к малым афористическим жанрам» [Петрова 2002: 109]. В произведениях, построенных на фольклорном материале, проявился дар поэта переплавлять, творчески перерабатывать народные традиции в оригинальные произведения. Ярким примером могут послужить такие поэтические циклы, как «Ключи разума», «Калмыцкий праздник», и поэмы «Час речи», «Все движет Женщина-Любовь», «Солнечный Лев», объединенные «темой историко-культурной преемственности» [Бурыкин 2005: 108]. Самостоятельность и творческий подход автора обнаруживается в тех дополнениях, которые она вносит в содержание произведений. В ряде случаев Ханинова, по сути, не меняет саму фольклорную модель, сохраняет фольклорные элементы в их первородном виде, в том же эстетическом значении, которое они имели, но при этом вносит свои нюансы, делает сюжеты более динамичными, расширяет композиционный и художественно-изобразительный контекст и т. д.

Синтез современной формы с национальной традицией актуализируется автором через жанровое своеобразие: стихи-йорялы, стихи-магталы, жанр миниатюры, в частности четверостишия, притчи, прозопоэзия и т.д. (об этом писали М. П. Петрова, А. А. Бурыкин, И. Б. Ничипоров, К. А. Джушхинова и др.). Данный вопрос подробнее рассмотрен в главе III. 
Как показывают произведения калмыцких русскоязычных поэтов, интерпретация ими устнопоэтических источников (сказок, легенд, преданий, пословиц и поговорок, древних жанров обрядовой поэзии) оригинальна и своеобразна. Авторы извлекают из фольклорного материала не столько образы, мотивы, художественные приемы, сколько общечеловеческую суть и смысл, высвечивая тем самым новые грани связи прошлого и настоящего.

Рассматривая тематический состав русскоязычной поэзии Калмыкии, нельзя обойти обращение поэтов к буддийской тематике. Первой здесь стала Р. Ханинова (подробнее об этом в главе III). На момент ее обращения к данной теме (в последнем десятилетии XX в.) в постсоветском обществе бурно развивались процессы возрождения национальных культур и религий. В Калмыкии в это время особое внимание уделялось проблемам восстановления статуса буддизма. Поэтому о возрождении религии автор говорит как о составной части процесса возрождения национальной культуры. Жизнеспособность этой тенденции доказывает и параллельное освоение сходных тем поэтами, пишущими на калмыцком языке, к примеру Э. Эльдышевым в поэме «Зая-Пандита, или Колесо Учения» (1999)», посвященной великому ойратскому просветителю, религиозному и политическому деятелю Зая-Пандите НамкайДжамцо (1599-1662).

Говоря о современной русскоязычной поэзии Калмыкии, необходимо сказать и о ее жанровом составе. В творчестве авторов получили развитие самые различные жанры. Однако, как отмечают исследователи, основополагающим, начиная с 1970-х гг., является жанр лирического стихотворения. Особенно интенсивно развивается лирическая миниатюра, что связано и с «возросшей творческой зрелостью поэтов» [Лубинецкий 2007: 148], и с проникающим в калмыцкую русскоязычную поэзию медитативным началом. В небольших, но емких стихотворениях предстают философские раздумья о жизни, месте человека в мире, о познании загадок его внутреннего мира, его предназначении, диалектики его души. Великое и малое, попадая под «микроскоп» анализа поэтов, 
равным образом обретает глобальные параметры, масштабность, универсальный и всеобъемлющий характер.

Четверостишия Р. Ханиновой представляют собой гармонический синтез эмоции и разума, отражают работу души, радость познания. Глубокий нравственный опыт, энергия пытливой, философски насыщенной художнической мысли, сочетающаяся с удивительно емкой образностью, меткостью и экспрессивностью, напоминают, как отмечает А. А. Бурыкин, «Вереницу четверостиший» Анны Ахматовой:

Непрочна связь у сущего с живым,

Конечность, зародившаяся с ним.

Конец концов, начало всех начал -

Едва вдохнул, а выдох исчерпал [Ханинова 1994: 219].

Неотъемлемая часть ханиновских четверостиший - обращение к извечным человеческим проблемам: память и время, встречи и разлуки, природа и вечность. Продолжая традиции русской классической поэзии, автор отражает своеобразную диалектику жизни, стремится к ее философскому осмыслению:

Все проходит - и в этом трудность:

как смириться и как отдать?

Все проходит - и в этом мудрость:

Зная, истинно все приять [Ханинова 1994: 229].

Миниатюрам Р. Ханиновой присуще афористическое звучание. Справедливо мнение А. А. Бурыкина о том, что «этот жанр органичен в художественном мире Риммы Ханиновой: ее поэзии свойственны лаконизм, афористичность» [Бурыкин 2005: 105]. В этом заключается художественно-эстетическая сущность ее произведений. Все глубже постигая жизнь, она утверждает общечеловеческие ценности и естественное отношение к бытию. Поэт приходит к глубоким гуманистическим мыслям: призывает не лицемерить, быть мудрым, бескорыстным, милосердным, трудолюбивым, хранить чистоту сердца, но не быть при этом слишком доверчивым: 
Ты предал друга. Погоди

искать, сбиваясь, прегрешенья.

Ведь все, поверь, уж позади, -

Когда ты вынес то решенье [Ханинова 1994: 223].

В тяготении к миниатюре нельзя не отметить и влияние восточной традиции, в частности калмыцкой. Опираясь на материал устного народного творчества, многие жанры которого имеют в своей основе поучение, автор строит свои миниатюры как мудрые наставления, пропитанные глубокой и правдивой жизненной философией - житейской мудростью. Миниатюры, лирические по звучанию и назидательные по смыслу, посвящены многим жизненным ситуациям. На каждую автор имеет свой взгляд, он словно предупреждает читателя, предостерегает его от ошибок, советует, как правильно себя вести, чтобы избежать предательства, подлости, алчности, самообмана:

Долг не вернув, -

Не станешь ты богат.

С пути свернув, -

Отстанешь во сто крат [Ханинова 1994: 224].

Дидактическую направленность также имеет поэтический цикл миниатюр Р. Ханиновой «Ключи разума» (2004). Источником вдохновения для его написания послужил памятник древней монгольской литературы «Ключ разума» («Оюн тулкур»), написанный в жанре сургал (краткое афористичное поучение). Речь об этом пойдет в главе III.

Миниатюры Р. Ханиновой свидетельствуют о том, что этот жанр закрепился в калмыцкой русскоязычной поэзии, в нем достигнуты определенные успехи. Для этого направления характерно создание собственного поэтического пространства, когда конкретная ситуация приобретает чрезвычайное расширение и охватывает ключевые аспекты бытия. В произведениях этого жанра присутствуют размышления поэтов о времени, человеке, судьбах народа, об истинном и мнимом, добре и зле, смерти и бессмертии, труде 
поэта и множестве других вопросов. При этом в успехе освоения жанра миниатюры сказалось влияние традиций как русской литературы (желание и умение поэта насытить предельно малый объем значительным содержанием, которое, подчиняясь требованиям формы, концентрируется, сгущается, уплотняется), так и восточной (стремление к дидактике, поэтическим сентенциям, афористическим звучаниям, поучениям, представляющим собой утверждения или обобщения). В рамках данного жанра авторы активно обращаются к духовному наследию народа, знанию своих истоков, корней, кровного единства с ними как символа духовной высоты.

Жанр поэмы современными русскоязычными поэтами осваивается не столь интенсивно, в отличие от поэтов, пишущих на родном языке, в творчестве которых он очень популярен. В русскоязычной поэзии достижения в развитии жанра поэмы связаны, прежде всего, с именем Р. Ханиновой. В творческом арсенале поэта насчитывается пять лирико-философских поэм («Час речи», «Формула судьбы», «Все движет Женщина-Любовь», «Солнечный лев», «Справедливый И»), родившихся, собственно, вслед за переводами поэм отца.

Свидетельством новых, растущих возможностей калмыцкой национальной русскоязычной поэзии становится стремление к циклизации стихотворений, объединенных на основе идейно-тематической общности.

Циклы лирических стихотворений получают распространение, в частности, в творчестве Риммы Ханиновой. Как отмечают исследователи, стремление к циклизации - одна из характерных особенностей творчества поэта [Джамбинова 1999: 99-100]. Яркие примеры тому - циклы «А жизнь, как тишина осенняя, - подробна...», посвященный Б. Пастернаку; «От всего человека вам остается...», посвященный памяти И. Бродского; «В тени Конфуция», в котором развивается диалог с выдающимся мыслителем древности; «Древние метаморфозы» - обращение к философским глубинам древней мифологии. 
Следует отметить, что Р. Ханинова первой среди калмыцких русскоязычных поэтов обратилась и к жанру драматургии. Так, в 2009 г. ею была написана пьеса «Легенда о Джангарчи».

В целом жанровая структура современной русскоязычной литературы Калмыкии раскрывает внутренний мир поэтов во всем многообразии связей с окружающей действительностью, временем, контактов с современником. Можно заметить интенсивное расширение жанровой структуры, при котором, с одной стороны, в ней представлены классические жанры, подтверждающие свою жизнеспособность (лирическое стихотворение, баллада, поэма), а с другой - трудно поддающиеся систематизации новые жанровые формы, не вполне традиционные для калмыцкой литературы. Расширение жанровых границ современной русскоязычной лирики происходит и за счет проникающего в нее медитативного начала, выражаемого через освоение ряда форм восточной и западноевропейской лирики. В результате авторы начинают осваивать не традиционные для калмыцкой поэзии жанры (поэтические циклы, стихотворения в прозе и т. д.). Перед авторами открываются новые пути поисков, решений и новаторских открытий, складываются такие типы поэтического мышления, как медитативно-аналитический, мифологический, каждый из которых обладает своей стилистической системой.

Широкое внедрение новых, нетрадиционных средств художественной выразительности в творческую практику обусловлено не только индивидуальностью самих авторов, их мировидением, эстетическими представлениями, своеобразием поэтического мышления и интересами. Это, в первую очередь, результат длительного пребывания калмыков в пространстве русской и мировой культуры, использование ее опыта. Об этом свидетельствуют как национальная литература, так и другие виды искусства, в которых появляются новые интонации, новая палитра средств художественной выразительности. Характерным является несвойственное для национальной литературы расширение жанрового диапазона лирики, происходящее в результате освоения литературных 
форм, сформированных экстравертной природой европейского художественного мышления (например, лирической поэмы и т. д.).

Поэтическое русскоязычное творчество постоянно обогащается новым содержанием и образными формами (включение различных жанров, композиционных построений). Это объясняется, прежде всего, тем, что авторы опираются на сложившиеся традиции и достижения предшественников, а также вносят свой вклад в процесс развития поэтического искусства. Неслучайно А. Г. Салдусова, говоря о русскоязычной поэзии В. Лиджиевой, разножанровом творчестве Р. Ханиновой и других авторов, отмечает их тяготение «к книжной традиции, что свидетельствует о движении национальной поэзии по горизонтали - вширь, когда в состав поэтического текста активно внедряется мировой культурно-исторический, художественный опыт эпох и народов» [Салдусова 2009: 510-511]. Подобная интеллектуализация поэзии в конце ХХ в. является «отражением процессов урбанизации, глобализации общества, которые происходят в мире, стране, республике и влияют на духовный мир современника» [Салдусова 2009: 510-511]. В этом плане показательны творческие поиски русскоязычных поэтов. В своих произведениях они стремятся дать ответ на злободневные вопросы с точки зрения человека конца XX в. - начала XXI в., впитавшего в себя евразийскую культуру. Это вечно живые вопросы жизни и смерти, добра и зла, веры в красоту Слова и духовное бессмертие человека. 


\section{ГЛАВА ІІ. ЭТНОКУЛЬТУРНОЕ ПРОСТРАНСТВО ПОЭЗИИ ДЖАНГРА НАСУНОВА}

\section{1. Поиск этнонациональной идентичности и этнокуль- турные концепты как основа художественной картины мира в поэзии Д. Насунова}

Творчество калмыцкого поэта Джангра (Виктора Ивановича) Насунова (1942-1979) представляет собой уникальное явление, занимающее особое место в калмыцкой литературе. Оно еще недостаточно изучено, лишь отдельные его аспекты затрагивались в работах современных калмыцких литературоведов [Э. В. Лубинецкий, А. Г. Салдусова, Р. М. Ханинова].

Поэзия Д. Насунова представляет собой определенный этап взаимодействия в литературе двух культур, русской и калмыцкой. В ней нашли отражение своеобразие национального художественного наследия, а также традиции русской классической литературы, что позволило с необыкновенной полнотой передать всю «сложную систему нравственно-психико-чувственных традиций, характеризующих духовный склад нации» [Гусейнов 1988: 45].

Тот факт, что Д. Насунов создавал свои произведения на русском языке, объясняется объективными историческими условиями. Он - один из представителей «сибирского поколения» калмыков, волею истории переживших насильственную депортацию, родившихся и выросших вдали от родины, а значит - вне языковой среды, поскольку, как уже отмечалось, в отличие от ряда других народов, подвергшихся незаконному выселению, калмыки были лишены возможности общения на родном языке вследствие дисперсного расселения от Аральского моря до Сахалина, от Таймыра до Узбекистана. Смешанный брак родителей: отец - калмык, мать - русская, учеба в русской школе, а затем в московском институте, - все эти факторы, типичные для многих русскоязычных писателей, оказались решающими - Д. Насунов калмыцким языком практически не владел. 
Вот что написал сам поэт в краткой автобиографии: «Я сын потомственного табунщика. Родился 22 июля 1942 года в селе Яшалта Калмыцкой АССР. Детство и мои школьные годы прошли в Сибири в г. Черепаново Новосибирской области. Там, в 1957 г., зимой, умер мой отец. Осенью того же года наша семья вернулась в родную Калмыкию. Семья у нас большая, и я был вынужден бросить восьмой класс дневной школы и идти на производство. Устроился разнорабочим в к-зе «Новый мир», одновременно учился на курсах механизаторов. Окончив их, работал трактористом в том же колхозе. В 1966 г. переехал в Элисту. Здесь заочно окончил 11 классов. В настоящее время работаю ассистентом режиссера Калмыцкого телевидения. Работа трудная, но, как говорил мой отец: «Сел на необъезженного коня - укроти его». В свободное от работы время пробую писать стихи. Пишу на русском языке. Есть какая-то аналогия между человеком, впервые севшим на коня, и начинающим поэтом. Укрощение скакуна связано с такими же трудностями, как и стремление подчинить себе слово, чтобы мысль свободно и непринужденно вылилась в строгую, четкую форму. Часто меня постигают неудачи. Но мой отец говорил: «Кто упал с коня и не нашел в себе силы вновь сесть в седло, никогда не будет хорошим всадником».

В поэзии я начинающий наездник, но хочу стать настоящим джигитом. Хочу получить литературное образование, хочу учиться в Литературном институте им. Горького. Джангр Насунов» [Щеглова 2012: 4]. Эту краткую автобиографию, хранящуюся в канцелярии Литературного института им. А. Горького, Д. Насунов написал 26 июля 1968 г. при поступлении. Права Л. Щеглова в том, что написать столь образную, столь искреннюю и яркую автобиографию мог только настоящий художник слова. В апреле 1974 г. поэт закончил институт.

Впервые автор начал печататься еще до поступления в институт в местной периодике, затем в столичных журналах «Молодая гвардия», «Москва», «Юность», «Аврора», «Волга», в альманахе «Родники», его произведения вошли в антологию молодых писа- 
телей РСФСР, вышедшую в Киеве на украинском языке под названием «Березова криница» («Березовый колодец»). Первые насуновские публикации в прозе относятся к началу 1970-х гг. («Самостоятельное решенье», «Ботхн», «Адьян» и др.). В 1971 г. он выпускает свой первый сборник стихов «Голоса расстояний». Всего издано четыре сборника стихов поэта, два при жизни - «Голоса расстояний» (1971), «Поселенцы» (1977), и два после смерти «Полет копья» (1980), «Тамариск» (1982).

Прижизненные поэтические сборники Д. Насунова не отличаются четкой структурой, тем не менее заметно следование автора некоторым тематическим принципам. Так, сборник «Голоса расстояний» строится по принципу включения избранных произведений поэта. В сборнике «Поселенцы», посвященном памяти первого учителя Д. Насунова, преподавателю языка и литературы М. Т. Симоновой, выделяются такие темы, как сибирское детство, война и калмыцкая культура.

Аналогично составлены и сборники, вышедшие после смерти поэта. В книгу «Полет копья», включены избранные стихотворения, преимущественно посвященные калмыцкой истории и культуре. Среди них такие ударные произведения Д. Насунова, как «Джангарчи», «Сказка о льстивом тайше, жестоком хане и самой Справедливости», «Рандул и Галдан», не вошедшие в прижизненные сборники поэта.

В сборнике «Тамариск» стихи подразделяются на тематические группы. Об этом можно говорить лишь исходя из тем и анализа мотивов вошедших в него произведений, специально же никакие разделы не выделяются. Сборник начинается со стихотворений, посвященных родной природе («Степь и люди», «Тюльпан», «У нас в степи капризная погода», «Тамариск» и т.д.), далее следуют стихи на военную тему. Отдельные группы составляют произведения, связанные с духовно-нравственной проблематикой, в том числе актуальной для 1970-х гг. темой дружбы народов. Наибольший объем занимают стихи фольклорной и исторической тематики, воссоздающие мир народных обычаев и традиций. 
Надо также заметить, что если во всех книгах Д. Насунова художественный материал дублируется, то в «Тамариск» вошли неопубликованные ранее стихи: «Помню дождь в березовом лесу...», «Стрела лихая зависти и злости...», «Нет от друга ни слова, ни строчки...», «Искал себе женщину лучше...», «Узором никого не удивить... » и другие.

Незнание поэтом родного языка переживалось им как трагическая, непреодолимая утрата, являлось источником постоянного внутреннего разлада, отзвук которого оставил глубокий след во всем его творчестве. При этом характер его поэтического мира во многом связан с глубоко развитым чувством причастности к судьбе и культуре своего народа. «Будучи сыном двух народов - русского и калмыцкого, - к тому же пишущий на русском языке, он ощущал себя «настоящим, истинным калмыком» и хотел, чтобы также воспринимали его читатели» [Щеглова 2012: 4]. Неслучайно поэт взял себе псевдоним Джангр, который отражал глубинные корни его поэзии, связь с фольклорными и культурно-историческими традициями. Джангар, как известно, - имя главного героя калмыцкого героического эпоса, повелителя многих народов. Кроме того, расположение дворца Джангар-хана и его трона маркирует семантически значимый центр в национальной картине мира. В связи с этим выбор псевдонима получает особое значение, выражая стремление поэта быть в центре народной культуры. Имя Джангр считалось сакральным и вплоть до 1930-х гг. ХХ в. не являлось распространенным в антропонимии калмыков, это имя не давали детям во избежание сложной судьбы и ответственности за семантику. В 1960 - начале 1970-х гг., в период подъема национального самосознания, героический эпос «Джангар» стал символом национального возрождения, именами его героев стали нарекать детей.

Как верно отмечает Д. Б. Дорджиева, всю жизнь, с раннего детства, Джангр Насунов ощущал в себе потомка номадов. Это «генетическое ядро» отчетливо слышится в его раннем стихотворении, отражающем «начало жизненного опыта» поэта [Дорджиева 2012: 23]: 
Мне этот день до смерти не забыть -

Когда я мчал на диком скакуне

С единственным желаньем укротить,

И значит - удержаться на коне [Насунов 1982: 29].

Народное начало в поэзии Д. Насунова живо и ярко проявляется в создаваемых им поэтических картинах, в психологических коллизиях, в образе лирического героя, чей внутренний мир составляют архетепические категории, образующие в совокупности образ родного края. Это степь, тюльпан, полынь, конь, сайгак, через изображение которых поэт раскрывает этнические особенности видения мира, его духовно-нравственные ценности.

В творчестве Д. Насунова тема любви к родной земле занимает центральное место. Это его опора и источник, откуда он черпает творческие силы. Чувство любви к родине, обостренное пониманием насильственной отлученности от нее в детстве, придает его стихам необычайный лиризм, нередко переживания автора обретают драматическую, порой трагическую напряженность.

Образ отчего края неразрывно связан с образом степи, она душа насуновской поэзии, источник неизбывного вдохновения. Именно ее красота, неяркая и скромная, и тем не менее придающая ей неповторимость и очарование, пробуждает все чувства поэта и воодушевляет его. Только степь вызывает чувство полноты жизни и гармонии с окружающим миром. В стихотворении «Здесь ты не встретишь броской красоты...» ярко и эмоционально передана неотделимая от сознания поэта дума о родной земле, согревающая и возвышающая душу:

Здесь ты не встретишь броской красоты,

Чтоб сразу обожгла до слез,

до вскрика...

О степь моя, иным -

невзрачна ты,

Но красота твоя в душе калмыка.

Я эту красоту в себе ношу, 
Она в соседях, в матери и в сыне.

Прохожие, я об одном прошу:

Не говорите плохо о полыни.

Чабан вам скажет, сидя у огня,

Не в силах скрыть волнение и трепет:

«Вы постигайте степь через меня,

Меня вы постигайте через степи» [Насунов 1977: 7].

Поэт одухотворяет природу, преображает творческим зрением. Стихотворение характеризуется точностью и завершенностью поэтической мысли, экспрессией чувств автора, умеющего находить красоту там, где не каждому дано ее заметить, подмечающего все, что ускользает от обычного взгляда. В финальной части стихотворения глубоко и проникновенно выражаются чувства безграничной любви, преданности и неразрывной связи народа с родной землей.

Лирическому герою присуще цикличное мировосприятие восточного человека, «когда субъект выделяет, но не отделяет себя от окружающего мира» [Морохоева 1994: 5]. Степь является для него сакральным местом, где раскрывается душа, поверяются самые заветные тайны и появляется чувство сопричастности с миром. Они - степь и поэт - словно единое целое:

О, степь моя,

с тобой не одинок я.

Я пью тебя,

простор твой,

зеленя.

Не потому ль задумчив и широк я,

Что ширь твоя

навек

влилась в меня [Насунов 1980: 17-18].

Степь становится для поэта символом физически-духовного раскрепощения, целостности мира. Герой в открытости степного пространства чувствует себя словно в центре Вселенной. Слит- 
ность с миром природы, осмысление кровного единства и родства с матерью-степью, ее одухотворение транслируется во всей пейзажной лирике Д. Насунова. Поэт видит не внешнюю красоту родной природы, он познает безусловную суть понятия «родина», что становится источником настоящего чувства верности, любви и преданности ей. Это глубокое внутреннее самоощущение характерно для всего творчества поэта, является отражением души его лирического «я», указывает на синкретизм сознания художника. Он верит в таинственную самостоятельную жизнь степи, в которой все одухотворено, она является для него мистической явью, «чудом», к которому он стремится как к смыслу жизни:

И с той поры мне степь явилась чудом,

Где каждый листик что-то говорит.

Я в степи врос и вырос я оттуда,

И степь меня питает и растит [Насунов 1988: 16].

Горячая любовь к родине - лейтмотив всего творчества Джангра Насунова. В его стихах ощущается сыновняя привязанность к каждой травинке, каждому камушку, - он не пренебрегает любой, даже мелкой деталью. Так, поэт с нежностью воссоздает образ полыни, горьковато-пряный, щемящий душу, терпкий запах которой дорог любому степняку:

В чужих краях подчас я сам не свой, Дряблеет кожа, старюсь на чужбине,

И рвусь я в степь, где сладок летний зной,

Настоянный на запахе полыни [Насунов 1977: 26].

В полыни, по мысли автора, скрывается магическая сила, ибо эта скромная, неприметная трава - олицетворение живой связи с родной землей. Сокровенное, трепетное восприятие родной природы, переданное в стихотворении «Запах полыни», показывает, какими одухотворенными могут быть взаимоотношения человека с окружающим миром:

Я забирался в заросли кустов,

Шел по горам, кружился я в долине - 
В краю благоухающих цветов

Мне не хватало запаха полыни.

Была радушна горная страна...

Повсюду лишь приветливые лица,

Но ко всему мне так была нужна

Родной степи та малая частица... [Насунов 1982: 8].

Основные категории этнической культуры, семантически выражающие специфику мировосприятия любого народа, - время и пространство. Для Д. Насунова время, цикличное и беспредельное, сливается с образом национального мира, этнического пространства, главным символом которого является безграничная и вечная степь. В стихотворении «Запах полыни» поэт противопоставляет пространство горной страны и степного края, используя метод оппозиции «свой - чужой», являющийся в культуре монгольских народов одним из важных.

Общеизвестно, что специфика восприятия каждым народом «пространственно-временного континуума», «того единственного фона, на котором развертываются все явления природы и культуры» [Жуковская 1988: 5-6], различна. В культуре калмыков основные черты, характерные для пространства и времени кочевников, проявляются в традиционных представлениях о «земле-воде» понятии, прежде всего, взаимосвязанном с образом бескрайней степи. Отсюда особенность «степного» мышления калмыка-кочевника, особое постижение мира, жизни, связи человека и природы. Только в безбрежном пространстве, «сочетающем в себе огромность и размах пейзажа с цветущим буйством жизни природы» [Надъярных 2008: 215], где все зримое и осязаемое несет в себе звуки и запахи конкретного национального мира, его тепло и душу, степняк чувствует свободу и внутреннюю гармонию. В этой беспредельной широте человек, переполняемый «чувством безгранично-могущественного, или безгранично-большого», которое обычно «вызывают море, лес и горы» [Надъярных 2008: 215], проникается полнотой жизни, ощущает себя слитым с природой, со всем окружающим его миром. Именно поэтому лирический герой 
Д. Насунова, искренне восхищаясь и преклоняясь перед несомненной, пленительной красотой горного края, страной добрых и гостеприимных людей, хранит в душе образ отчей земли, все его мысли и думы о степи. В чужом краю ветка горькой полыни - это олицетворение родного дома, частица степи, животворный источник, который дарит лад и гармонию:

Но вот нашел и бережно прижал

Полынь к губам, от счастья пламенея,

И край вершин задумчивых и скал

Мне сразу стал дороже и роднее [Насунов 1982: 8].

Мелодию стиха Д. Насунова определяет глубокая эмоциональность, искренность, задушевность. Ностальгические ноты звучат в стихотворениях, посвященных памятным сердцу местам. В стихотворении «Куда б ни шел, где б ни был в этом мире...», основанном на автобиографических моментах, оппозиция «свой - чужой» снимается: в сердце лирического героя любовь к родному краю и тоска по далекой Сибири, где прошло его детство, сливаются в единое целое. Это неоднозначное и сложное движение чувств - свидетельство расширения поэтического мышления автора: от осознания неродного края чуждым, немилым («Запах полыни») к ощущению «чужого» не просто своим, а максимально близким, родным. Подобное мирочувствование раскрывается в сложном движении эмоций, сталкивающихся и сливающихся в душе поэта:

Куда б ни шел, где б ни был в этом

$$
\text { мире, }
$$

Со мною зной и лютые снега.

Рожден в степи, а вырос я

$$
\text { в Сибири, }
$$

Мне дорог лес и степь мне дорога.

Я, как сайгак, бродил в таежной

И рвался в степь, грустил я

чаще

каждый день, 
А вот в моей Калмыкии все чаще

Я по тайге тоскую, как олень [Насунов 1971: 5].

Противоречивость чувств, которые обуревают лирического героя, любовь к двум родинам, Калмыкии и Сибири, остро и тонко выражаются автором посредством поэтической антитезы, определяющей структуру всего стихотворения и четко отражающей состояние лирического героя: зной - лютые снега, степи лес, олень - сайгак. Удачны меткие сравнения, выбранные автором. Вначале лирический герой олицетворяет себя со степным сайгаком: «Я, как сайгак, бродил в таежной чаще, / И рвался в степь, грустил я каждый день» [Насунов 1982: 5]; затем - с оленем, обитателем тайги: «А вот в моей Калмыкии все чаще, / Я по тайге тоскую, как олень» [Насунов 1982: 5]. Мир природы, представленный в данном стихотворении образами животных, является символом человеческих чувств и представлений, при этом художественно-изобразительные средства, образные сравнения усиливают идейное содержание произведения, помогают выразить душевные переживания лирического героя. Чувство любви к родной Калмыкии не утрачивает своей глубины и искренности от признания в любви к другим краям.

Глубокое патриотическое чувство вызывает другой поэтический образ, символизирующий калмыцкую степь, - образ тюльnана, ставший традиционным в калмыцкой литературе. В стихотворении «Тюльпан» в зарисовке степного пейзажа автору замечательно удалось запечатлеть красоту родной природы:

В степи сейчас ни слякоти, ни пыли,

И скот легко бредет на водопой,

Лишь облаками пыльными застыли

Верблюды над заброшенной тропой.

Стремясь крылом объять свои владенья,

Степной орел свершает свой полет

И по верблюжьей вытянутой тени

Сейчас, быть может, время узнает. 
И видит взором яростным, орлиным

С огромной высоты степной орлан,

Как в этот час средь дымчатой полыни

Пылает вызывающе тюльпан [Насунов 1977: 28].

Живописная картина, воссозданная художником, полна очарования и величественного покоя. Всем образным строем, подробностями пейзажа и самим ритмом стиха создается представление о том, что внутренний мир лирического героя глубок, его покоряет величие бескрайних просторов степи, окружающая тишина, ощущение вечности и умиротворенности на лоне природы. Автору, бесспорно, удалось передать неуловимое состояние слияния природы и человеческой души в единую целое.

Тюльпан - яркий символ родного края. Его образ дорог сердцу поэта своей неповторимостью: тюльпан цветет лишь раз в году, весной, - и тогда степной пейзаж обретает неповторимую красоту:

Из-под земли он вырвался весною

Всего лишь на мгновение одно,

Как вызов наступающему зною,

Коль в схватке с ним погибнуть суждено.

И в небо одуряющее глядя,

На цыпочки привстал он от земли.

И тень орла его тихонько гладит,

И льнут к нему седые ковыли [Насунов 1977: 28].

При помощи метафоры действия («и в небо одуряющее глядя, на цыпочки привстал он от земли») тюльпан наделяется человеческими качествами. Природа словно сливается с миром людей: «как вызов наступающему зною», дождавшись с нетерпением своего часа, тюльпан буквально вырывается «из-под земли» и, привстав на цыпочки, глядит в «одуряющее небо». Эпитет «одуряющее небо» в данном случае воспринимается не просто как нечто большое, необъятное, но и, скорее, как символ чего-то несбыточного, передает романтически-приподнятое, поэтическое настроение лирического героя. В строке же «и тень орла его тихонько гладит...» 
через поэтический троп поэт передает заботливое, бережное отношение к этому цветку. Тюльпан бесконечно дорог автору, он пишет о нем с беспредельной нежностью, связывая с ним все задушевное, заветное, идущее из глубины сердца.

Еще одной составляющей поэтической картины родного края в поэзии Д. Насунова является образ тамариска. Поэт тонкой души, с особой нежностью и чуткостью относящийся ко всему живому, показывает через этот образ, какими трепетными и сильными могут быть взаимоотношения человека с родной землей, говорит об их слиянности:

...А тамариск, растущий по-над речкой,

Уходит в степь, теряется вдали,

И я, как он, прирос к земле навечно,

И он, как я, восходит от земли [Насунов 1982: 13].

Небезынтересным представляется творческое переосмысление автором слова «тамариск».

Растет в степи кустарник тамариск,

Два слова «там» и «риск» в его названье.

Мой тамариск, я знаю, любит риск

И рисковать всегда - его призванье...

Он над обрывом ветви разбросал

И в берег врос упрямый и бывалый.

И весь на грани грозного обвала

Он сдерживает давящий обвал [Насунов 1982: 13].

Поскольку лирическое «я» поэта отождествляет себя с тамариском, новое толкование слова принимается сразу, безоговорочно, ибо возникает образ человека деятельного, активного. Яркое поэтическое воплощение получает авторская мысль о том, что жизнь состоит из постоянных испытаний, трудностей, для преодоления которых необходимы упорство, терпение и воля. Все человеческое существование, безусловно, проникнуто началом борьбы, где не обойтись без риска и бесстрашия. Тамариск Д. Насунова символизирует стойкость, силу духа человека. И душу са- 
мого поэта, которая «легкоранимая, мужественная, нежная, жила на острой грани жизни, сдерживала натиск времени, быта, людей, пребывавших в ином измерении» [Дорджиева 2012: 23].

В творчестве Д. Насунова есть немало произведений, посвященных Maнblчу. Этим именем называют в Калмыкии систему рек и озер Кумо-Маныческой впадины. Поэт любит разговаривать с Манычем, прислушиваться к нему, улавливать каждое движение. Он приходит к нему как к верному другу в моменты отчаяния и безнадежности, в минуты тяжелого душевного разлада. Это один из любимых образов автора, живо воскресающий в его памяти родные яшалтинские равнины. Здесь, у берегов и разливов «синевато-зеленого» Маныча-Гудило, беспокойная, мятущаяся душа лирического героя обретает покой, сбрасывая тяжелый груз проблем и забот. Река, как и поэзия, - прибежище от суеты и маеты дня. Кажется, что Маныч ласкает и согревает героя своей теплотой, обладая чудодейственным свойством умиротворять тревожную душу. В этом растворении во всеутешающей гармонии бытия чувствуется органическое родство с матерью-природой, ощущение подлинности жизни, ее ценностей. Лирический герой преклоняется перед мудрым Манычем, просветляющим душу и сердце:

Вдали ворчит, рыдает Маныч

Не от обид, а просто так, И криком чаек манит, манит, И не удержишься никак.

А к черту город, шум и споры,

Страстей извечную войну.

Я завтра снова на просторе

Хлебну соленую волну.

И буду снова Робинзоном

В краю стрижей и сазанов.

Без светофоров и газонов,

Рвачей и тещиных блинов.

И с безмятежностью тюленьей

Лежать я буду у воды, 
Объятый легким чувством лени

И без предчувствия беды.

У ног плескаться будут волны,

Пройдет задумчивая грусть,

И на прощанье, просветленный,

Реке я низко поклонюсь.

И, по обычаю, монета

Мелькнет и скроется в волне,

И под водой, блеснув кометой,

Звездой засветится на дне [Насунов 1977: 42].

Стихотворение «Маныч мой синевато-зеленый» построено в форме диалога лирического героя со степью и озером. Автор обращается к Манычу, как к близкому и родному, дружески называя его «стариной» и, тем самым очеловечивая его. Поэт показывает, что две стихии - земля и вода (степь и озеро) - зависимы друг от друга. Здесь в некоторой степени раскрывается специфическое национальное видение мира, присущее кочевой цивилизации. Как мы уже отмечали, у монгольских народов существует нераздельное словосочетание «земля-вода», употребляемое в значении «родные кочевья», «родина». Почитание элемента воды, в котором «извечно заложен высокий ритуальный и философский смысл» [Надъярных 2008: 128], как и других элементов (земля, дерево, металл, огонь), является обязательным и носит сакральный характер, находя свое выражение в различных обрядах, известных с незапамятных времен у монгольских народов:

Маныч мой синевато-зеленый,

Ты ответь мне быстрей, старина,

Почему же ты горько-соленый?

— Потому что земля солона.

Степь моя, широка, бесконечна, Почему ты травою скудна?

- Потому что у Маныча вечно,

Сколько помню, вода солона. 
Этот спор не считаю нелепым,

Только знаю: в краях ветровых,

Как без Маныча степи - не степи,

Так и Маныч — не Маныч без них [Насунов 1982: 8].

О значении воды для засушливой степи и ее обитателей говорится и в стихотворении «Степной родник». В знойной степи вода является чудесным даром природы, пробуждающим все живое. В представлении автора перед родником равны все: и простые кочевники, и воины, «сам хан и тот склонялся перед ним». Однако «злой нойон, мстя беднякам восставшим», задумал заглушить родник, заведомо зная, что жизнь людей в летнюю жару немыслима без воды:

Степной родник, ты, силы обретая, Назло пескам пробился сквозь пески.

Вода, вода обычная, простая,

Тебя святой считали степняки.

Жизнь без тебя немыслима средь зноя,

В седле не усидеть и степняку...

От жажды изнывая после боя,

Кочевники тянулись к роднику.

К нему склонились воины, их жены,

Столетний старец, жаждою томим,

Не устыдясь рабов и приближенных,

Сам хан и тот склонялся перед ним.

Текли года.

В степном краю пропащем

Под небеса взлетел восстанья крик.

И злой нойон, мстя беднякам

восставшим,

Овчинами забил живой родник.

И тот нойон, задумав это мщенье,

Его свершая, понимал тогда,

Что те овчины неподвластны тленью -

Они родник забили навсегда. 
...Плыла жара, и умирали дети,

И повторял в бреду один старик:

«Нет злодеянья большего на свете,

Чем заглушить в степи живой родник»...

[Насунов 1980: 3031].

Последние две строки («Нет злодеяния большего на свете, / Чем заглушить в степи живой родник») звучат рефреном в стихотворении, усиливая главную мысль автора о том, что дороже всякого богатства на земле - вода. Именно она - символ и олицетворение жизни, величайшего добра.

Родная природа - духовное пристанище Д. Насунова, источник, который дает импульс его творчеству. Бескрайние просторы степи, мятный запах полыни, пушистый ковыль, пылающие тюльпаны, «горько-соленый» Маныч и журчащие родники - эти образы окружающей природы являются в лирике поэта не просто «дежурными компонентами национальной идентичности» [Султанов 1996: 28]. Через них Д. Насунову удалось раскрыть мировосприятие, специфику мировоззрения калмыцкого народа, создав тем самым свою «национальную модель мира» (Г.Д. Гачев), в центре которой человек, кровно связанный с родиной, с жизнью своего народа. Воспевая своеобразие и неповторимость отчего края, лирический герой ощущает себя неотъемлемой частью окружающего мира и потому способен воспринимать и видеть его в таких взаимодействиях и взаимосвязях, которые заметны не каждому. Природный мир, чувственно воспринимаемый поэтом, является не только выражением своеобразия лирического «я», но и способом воссоздания образа родины, открытия ее пространств, средством отражения диалектики этнического мировидения, мироощущения степного народа, что заставляет задуматься о глубинной сути понимания связи человека и родной земли.

Среди ряда поэтических образов Насунова особенно ярко выделяется образ коня. Как отмечает Е. Е. Балданмаксарова, «известна особая роль коня в культуре кочевых народов Центральной Азии, где он имеет ритуально-культовое значение и несет особую 
символико-семантическую нагрузку. В пантеоне божеств конь возглавляет культ животных, и считается, что он связан с космосом, в частности с солярным культом, и, соответственно, со стихией воздуха, поэтому образ коня ассоциируется с полетом, ветром, скоростью. Общеизвестны крылатые мифологические кони. Культ коня нашел отражение в разнообразных обрядах и обычаях, в сказаниях и песнях. Кочевник-степняк относился к коню с большой любовью, как к близкому другу, называя его «эрджи» - драгоценность, «хуляг» - скакун. У монгольских народов конь считался символом ума. Все это способствовало тому, что образ коня превратился в один из самых популярных и возвышенных мотивов, с которыми связаны чувства преданности, добра и любви» [Балданмаксарова 2006: 8-9].

Именно эта семантика образа раскрыта в стихотворении Д. Насунова «Случай в кино», где автор сумел показать искреннюю любовь человека к коню, восприятие его как близкого и верного друга. Воинственный напор коня отождествляется автором с «яростью льва», стройность и быстрота бега - с легкой поступью лани. Описание этих свойств контрастирует в произведении с взволнованным состоянием старика, потрясенного внезапной гибелью «буланого красавца». Несмотря на то что действие происходит в фильме, гибель коня герой воспринимает обостренно, как если бы это было на самом деле. Автор показывает, какие сильные чувства вызывает невосполнимая утрата коня. Все произведение выдержано в едином эмоциональном и интонационном ключе. В зачине стихотворения поэт выразительно передает душевную боль, сожаление, которые испытывает герой, сознающий факт постепенного исчезновения из жизни значимой для него и его народа составляющей - коней, которых прежде в степи было много. Затем действие подтверждает невысказанную, но очевидную мысль героя о вине в этой утрате людей, их жестокости:

«О скакунах в степи легенд немало,

Они отводят мусов ${ }^{1}$ и беду,

${ }^{1}$ Мус - злой дух. 
Но скакунов у нас почти не стало.

Пожалуй, с ними время не в ладу», -

Так думал дед, увидев на экране

Буланого красавца, дончака...

В нем ярость льва и легкость дикой лани,

А как несет в атаку казака!

Звенят клинки, и ржут надсадно кони,

Не по себе тут стало старику.

Вдруг вскрикнул он, прикрыл глаза ладонью:

Буланый в кадре рухнул на скаку...

[Насунов 1982: 16-17].

Все произведение выдержано в едином эмоциональном и интонационном ключе. Не только жестокость, но и нерациональность, неразумность свершившегося вызывают у старого калмыка сильную эмоциональную реакцию:

Погас экран, мы шли из зала рядом,

Дед тер виски и, чувствую, ослаб:

«Какой коня!.. Такой стрелять

не нада, -

И сокрушенно выдохнул: «Яглаб» ${ }^{1}$.

Он цену знал, наверно, аранзалам²,

И снова тряс взволнованно меня:

«Как он упал... какой коня

не стала,

Зачем стрелять хорошего коня?» [Насунов 1982: 16-17].

В речи старика-калмыка обращают на себя грамматически неправильные выражения: «Какой коня!.. Такой стрелять не нада», «какой коня не стала...». «Какой коня» - буквальный перевод калмыцкой фразы «ямаран мөриг?». «Ямаран» (русск. 'какой, какая, какое') - несклоняемое в калмыцком языке прилагательное, обозначающее оценку качества чего-нибудь. В данном случае фраза имеет восклицательный характер, выражает негодование,

${ }^{1}$ Яглаб - Боже мой.

${ }^{2}$ Аранзал - самый быстрый скакун. 
возмущение и сожаление. Словосочетание «какой коня» имеет отклонение от нормы, в чем сказывается незнание старым калмыком правил склонения русского языка. Появление гласной «а» в конце слов «не надо», «не стало» («Какой коня не стала...») характеризует особенности освоения русского языка иноязычными представителями, а в целом способствует составлению правдивого портрета представителя старшего поколения, которым является главный герой стихотворения. Кроме того, употребление этих слов, возможно, восстанавливает в сознании поэта образ его деда, который знал именно такой, «ломаный», русский язык. Национальный колорит воссоздается и употреблением автором калмыцких слов. Этим словам Д. Насунов дает объяснение в сносках. Так, «аранзал» определяется им как «самый быстрый скакун». Слово «яглаб», выступающее в тексте в качестве междометия, переводится автором как «боже мой». В разговорной, повседневной речи восклицание «яглаб», наряду с другими словами («хяярхн», «дярк»), выражает душевную взволнованность, восхищение, испуг, тревогу и т. п. Согласно исследованиям ученых, в частности Д. С. Дугарова, изначальная семантика слова «хяярхн» связана с представлениями о божестве-предке и может быть определена как «божество, предок, повелитель грозы, огня, молнии» [Дугаров 1991: 68], при этом символика слова «хяярхн» связана с табуированием имени архаического божества. Позднейшее снижение статуса данного слова обусловило употребление его в качестве прилагательного, хотя в молитвах оно имеет значение обращения. Подобное произошло с названием божества «Дара эк» (Тарамать) превратившимся в «дярк» - слово, которое получило значение эмоционального междометия и зачастую переводится как «боже мой».

Изобразительно-выразительные средства лексики в данном стихотворении Д. Насунова выполняют особую функцию: накладываясь на русскоязычную основу и обладая при этом этническим своеобразием, они придают тексту некоторый заряд национально- 
стилевой самобытности, отображают образ мышления героя. Этнически-окрашенные речевые вкрапления, используемые поэтом, отражают реальное бытие калмыцкого языка в условиях двуязычия. Их употребление в тексте органично и естественно благодаря мастерству поэта, его бережному воссозданию народной ментальности, что характерно для этностилевой специфики творчества Д. Насунова.

В стихотворении «А Маныч манит здешних и нездешних...» Насунов, используя одно из самых распространенных поэтических средств - сравнение, основанное, как известно, на сопоставлении двух предметов для пояснения одного другим, делает явления, предметы более видимыми и выразительными. Так, сравнение «дети - кони («как дети, скачут кони на рассвете...») дает предельное очеловечение образа. Через это интересное уподобление («дети - кони») хорошо просматривается нежное, необыкновенно трогательное, бережное отношение поэта к этим животным. В очередной строфе («вожак и тот похож на пацана») сравнение развертывается и еще более конкретизируется. Таким образом, в насуновских художественных образах, несомненно, просвечивает глубокая смысловая доминанта, в основе которой - национальное видение мира. Поэт мыслит традиционными образами, выражая то характерное, что свойственно калмыцкому менталитету.

В стихотворении «Награда» автор затрагивает период ссылки калмыцкого народа в далекую Сибирь - время, когда на родной язык был наложен запрет:

Вдруг земляка негаданно,

$$
\text { случайно }
$$

Я повстречал в сибирском далеке,

Но сам не мог спросить, как ни

печально:

«Чей будешь ты?»- на нашем

языке. 
Я знал, что есть калмыки

понаслышке,

Но отродясь не слышал свой язык,

И русский друг, отчаянный

мальчишка,

Мне раз сказал: «Какой же ты

калмык?»

[Насунов 1971: 6].

Слова сибирского друга ранят сердце юного лирического героя. В следующих строках передается натиск стремительно сменяющихся чувств: боль от унижения выплескивается в взволнованных восклицаниях. «Вспыхнувшее» чувство лирического героя следует рассматривать как проявление трансформационного процесса, происходящего у нас на глазах с личностью, меняющейся в критической ситуации и создающей в себе новую идентичность: этническое самосознание героя в корне меняется. Умение героя держаться на коне, по мысли автора, является неотъемлемым признаком принадлежности к национальной, родной культуре. Проявление такой способности героя становится отправной точкой отсчета его новой жизни, динамично трансформирующейся под воздействием окружающего мира. Лирический герой, несмотря на невладение родным языком, одним из признаков калмыцкой национальной идентичности, является в душе калмыком. В его образе явственно прослеживаются автобиографические черты самого поэта, точно переданы чувства, эмоции, переживания автора, связанные с поиском и утверждением своей национальной идентичности. В стихотворении «Награда» мы видим, как в современной поэзии через образы, характерные для традиционной культуры, можно проявить и оттенить самые глубокие и тончайшие переживания человека. Особой лирической экспрессии полны последние строки:

И чувство, неизвестное доселе,

С такою силой вспыхнуло во мне:

«Я докажу, что я калмык, Валера!

Я усижу на диком скакуне!» 
И я скакал, и свесившись, и стоя, Скакал, как на учениях джигит, И что-то слышал близкое, родное В гуденье ветра, в грохоте копыт, Отвагою мальчишеской объятый, Во весь опор каурого гоня, Вдруг гикнул я, как предок мой когда-то,

В степь направляя дикого коня, Я выбирал труднейшие преграды, Я был на все готовым в этот миг И принимал от друга, как награду: «Ты настоящий, истинный

калмык!»

[Насунов 1971: 6-7].

Сказанные сибирским другом слова являются для героя поистине наивысшей «наградой».

Образ коня, как один из компонентов национальной картины мира, в стихотворении раскрывает глубинную психологическую связь прошлого и настоящего. Поэт мыслит национальными образами, его генетическая память еще свежа, ибо он «ощущает присутствие, видит их внутренним зрением» [Гачев 1988: 98]: «Вдруг гикнул я, как предок мой когда-то, / В степь направляя дикого коня» [Насунов 1982: 26].

Детство поэта, как уже отмечалось, прошло в далекой Сибири. То было послевоенное время - труднейшие, голодные годы, полные при этом радостей и яркости впечатлений, свойственных юности. Отец, истинный степняк, и там не расставался с профессией коневода. Его сыновья, Виктор (Джангр) и Иван, а с ними и дочь Зоя находились постоянно возле лошадей. Детские впечатления объездки коня, обучение навыкам езды оставили яркий след в памяти будущего поэта, ведь именно тогда закладывались основы характера, шло формирование личности: 
Твержу себе: «Хотя бы повезло,

И я тогда мальчишкам докажу...»

Но, сброшенный каурым, как назло,

Я под кустом освистанный лежу.

Ты подошел, отец, и, горячась,

Прикрикнул раздраженно на меня:

«Ты думаешь о том, чтоб не упасть,

А не о том, чтоб укротить коня!»

Мне этот день до смерти не забыть,

Когда я мчал на диком скакуне

С единственным желаньем

укротить,

И, значит, удержаться на коне [Насунов 1977: 10].

Укрощение коня Р. С. Липец определяет как «нешуточное испытание и даже подвиг... Это своего рода инициация, доказательство того, что юноша созрел и как воин ....Мускульная сила, выносливость, мужество, интеллект, быстрота реакции - все должно быть противопоставлено человеком укрощаемому животному в этом поединке» [Липец 1984: 203].

Мотив испытания конем помогает автору раскрыть в определенном смысле жизненную функцию каждого человека, суть которой заключается в созидании вечных ценностей, бесконечном завоевании неизвестного, упорстве, преодолении невзгод и препятствий: «Сесть на коня - не сложная задача, / Труднее удержаться на коне» [Насунов 1982: 29], - пишет поэт в стихотворении «Трехлеток был горяч и необучен».

Подводя итог сказанному, можно отметить, что образ коня в поэзии Д. Насунова соотнесен с традиционными ценностями народа. Через его символику автор показывает не только роль и значение этого животного в жизни кочевого народа, его истории и культуре, но и раскрывает особенность социализации предков, обусловленную комплексом обычаев и верований, связанных с конем. И эта особенность является в его стихах одной из важнейших характеристик национальной идентичности. 
С образом коня в поэзии Д. Насунова связано также обостренное восприятие глубоких перемен в укладе жизни народа, следствием которых является утрата целостности традиционного народного миропонимания. В связи с формированием новых условий жизни, по мнению автора, народ может отойти от истоков, утратить самобытность:

В те времена без лишних назиданий

И сам отец, и дети, и жена

Шли к дончаку, что бился на аркане,

И укрощали злого скакуна.

Теперь в степи меняется картина,

И как-то слышал реплику одну:

«И на аркане бравого мужчину

Ты не притащишь нынче к скакуну» [Насунов 1982: 17].

Эта же тема звучит в стихотворении «Свидание», в котором поэт с сожалением констатирует, что в современной жизни нет места коню:

Он пренебрег возможным наказаньем,

Надеясь, что понять его должны.

На тракторе он едет на свиданье,

А за хотоном бродят скакуны.

А за хотоном бродят вороные,

Резвятся, как столетие назад,

Но в наши дни наездники иные -

На скакунов садиться не хотят.

А где-то от селения в сторонке

Донара размечталась при луне

О том, как ненаглядную девчонку

Жених умчал на диком скакуне. 
Но трактор вырастал на косогоре,

Спешил он по нескошенной траве, И вот - печаль у девушки во взоре,

И так сказала девушка Даве:

- С такой машиной справится мужчина,

Не удивишь. Но думается мне

Старо к любимой ездить на машине,

Но не старо - примчаться на коне...

Я завтра жду... У речки... На закате...

И ты, Дава, не смейся надо мной.

Умчи меня, как делали когда-то,

Чтоб храп коня!.. Чтоб ветер за спиной!..

[Насунов 1982: 40].

В сознании кочевника образы коня и человека неразрывно взаимосвязаны и, дополняя друг друга, составляют единое целое. Использование анафоры («А за хотоном бродят скакуны, / А за хотоном бродят вороные») передает грусть и обеспокоенность лирического героя, осознающего, что цивилизация оттесняет природное начало, угрожая тем самым не только природе, но и цельности и силе национального характера. Для того чтобы не утратить в стремительно меняющейся действительности, в которой приоритет отдается результатам развития науки и технологии, «живую душу», человеку необходимы некие духовные ориентиры. Животрепещущим остается вопрос, сумеет ли калмыцкий народ в новых условиях жизни сохранить национальные традиции предков. В стихотворении звучат нотки жалости к отжившей, но дорогой сердцу поэта стихии кочевой культуры, воплощенной в образе коня.

В этом контексте можно провести параллель с произведением С. Есенина «Сорокоуст». Русскому поэту так же, как и Д. Насунову, казалось, что новая жизнь, воплощенная в поэме в образе «железного коня», нарушает извечную гармонию человека с природой. 
Он испытывал не столько неприязнь к «железу», сколько жалость к тому, что безвозвратно уходит из жизни. Образ маленького беззащитного «красногривого жеребенка» в поэме символизирует не только исчезающий уклад деревенской жизни, но и все живое, одухотворенное, прекрасное. Как известно, С. Есенин писал свои стихи-ламентации, заботясь о ценностях духовных, нравственно-этических. Отсюда его враждебное отношение к «железному гостю»:

Скоро заморозь известью выбелит

Тот поселок и эти луга.

Никуда вам не скрыться от гибели,

Никуда не уйти от врага.

Вот он, вот он с железным брюхом,

Тянет к глоткам равнин пятерню... [Есенин 1990: 59].

Своеобразная национальная форма миропонимания, связанная с образом коня и основанная на фольклорно-эпической традиции, отражена в стихотворении Д. Насунова «Тишина», в нем необычайно тонко передается ощущение покоя и безмятежности:

Как хорошо, что рядом тишина.

Она во мне, она опять со мною, И в сердце очень нежная струна

Поет о тишине и с тишиною.

И в тишине парит моя земля, И нежится в объятиях апреля.

Прохлада ветерка. Шум ковыля.

Свист сусликов и жаворонка трели.

Пасется тихо белый-белый конь,

И кажется, он где-то во Вселенной...

И так тиха в моей твоя ладонь,

И на душе ни бурь и ни сомнений

Выразительный лирико-романтический эффект несут конкретные и точные образы (шум ковыля, прохлада ветерка, свист сусликов, трель жаворонка, белый конь), метафорическая лексика 
(объятия апреля, нежная струна), четырехкратный повтор лексемы «тишина», а также скопление в звуковой ткани стихотворения шипящих, глухих, свистящих согласных. Эта удивительная инструментовка как нельзя лучше передает картину тишины с ее приглушенными шорохами и звуками, отчетливо слышными в стихотворении (св-вс-п-Х-ж-ш). Д. Насунов подчиняет поэтическому замыслу каждое слово, стремясь в точности передать величавый покой, естественность и бытие природного мира, состояние умиротворения. Неслучайно автор вводит образ белого коня («пасется тихо белый-белый конь»). У монгольских и тюрских народов кони светлой масти (белой, бело-желтой) считаются священными. Во время калмыцкого праздника начала лета Урюс сар священнослужители окропляли молоком белых кобылиц; подобный обряд сохранился у якутов, где во время национального праздника Ысыax, также связанного с началом лета, белых лошадей окропляют кумысом. По сведениям Л. П. Потапова, кочевники приписывали таким коням небесное происхождение и относили к пантеону божеств [Потапов 1977: 164-178]. Определение «белый-белый конь» включает в себя экспрессивный оттенок, в данном контексте подчеркивается не цвет, а чистота, возвышенность чувств, первозданность бытия. Сакральный белый цвет, олицетворяющий в культуре монгольских народов чистоту, благополучие, счастье и используемый «в качестве фактора эмоционального и эстетического воздействия, переносит в литературу свой символический код» [Дампилова 2005: 22]. Именно через образ белого коня создается идиллическая картина стихийной первозданной природы, обнажается ее хрупкость и беззащитность, основной при этом становится мысль о ее первоначальном единстве и органичной связи с человеком. В строках «пасется тихо белый-белый конь» выражена мысль о том, что в мире все ладно, гармонично и спокойно. Кроме того, этот образ, возможно, олицетворяет внутренний мир лирического героя, его состояние успокоенности и безмятежности. Обращение автора к образу белого коня связано, вероятно, с тотемистическим представлением калмыков об этом благородном животном. 
Анализ произведений показывает, что образ коня в поэзии Насунова является символом спокойствия, силы, красоты, а также выражением традиционных ценностей калмыцкого народа, важнейшим средством отражения его этнической культуры, его национального самосознания, мировосприятия, а также некоторых типичных этнопсихологических черт - стойкости, мужества, терпимости.

В образной системе калмыцкой поэзии одно из основополагающих мест занимает образ сайгака. В творчестве Д. Насунова, как и других калмыцких поэтов, этот образ часто ключевой в рассмотрении взаимоотношений человека и природы. Данная тема, связанная с бережным отношением к сайгакам, поднималась многими калмыцкими поэтами, например Д. Кугультиновым («Смерть сайгака, или расстрелянное утро»), Г. Кукарекой («Что ждет?», «Сайгаки», «Наша беда», «Моя вина», «Где сайгак?»).

Мировоззрение скотовода-кочевника как представителя традиционной культуры глубоко экологично, для него характерны представления об органичном единстве, равнозначности природы и человека. В духовной культуре народа, построенной на традиционной системе взглядов и воззрений, мир антропоцентричен, вся природа одухотворена. В центре этнического пространства - человек с его представлениями, верованиями. Он символически является центром Вселенной, как очаг кибитки маркирует ее центр. Кочевники «с младенчества усваивали мудрость: будь добр с природой, со степью, бери, не разрушая...» [Хайрулин 1999: 52]. Однако алчность, жестокость по отношению к животным превращают человека в убийцу, заклятого врага природы. Безжалостный браконьер Эмер в стихотворении Д. Насунова, пытаясь убить бедное животное, обрекает в итоге себя на смерть, при этом автор акцентирует внимание и на подлости друга, струсившего и покинувшего его в смертный час:

Бросок. И все смешалось на минуту.

И браконьер по имени Эмер,

Весь пылью обжигающей окутан, 
В сайгака бил ножом, но почему-то

Себя под сердце ахнул браконьер.

Лежит в степи и дышит хрипловато,

Но прочь бежит багровым ковылем,

Покинув умиравшего собрата,

Добытчик подловато-хитроватый,

Тот, что сидел все время за рулем [Насунов 1977: 40].

Люди нарушают священные заповеди предков, и начинается действие закона круговой взаимозависимости. Губя живую природу, человек совершает предательство, зло по отношению к ней, а итогом является трагическая гибель самого человека, неотвратимость наказания, расплата за надругательство над матерью-природой. Такова идея «Степной баллады».

Страшная сцена гибели сайгака показана в стихотворении «Подранок». Бездушный браконьер, издеваясь над раненым животным, пытается загнать его машиной. С гневом описывает Д. Насунов действия озверевшего человека. Обрекая природу на уничтожение, он не задумывается о том, что нельзя брать от нее больше, чем требуется, делая ее источником наживы. Тревожную интонацию в произведении передают олицетворения: «кричала степь», «прыгали барханы», «качалась степь», кроме того, для усиления эмоциональности и экспрессивности авторской речи используется прием тавтологии: «спасительные барханы», «спасительная река». Особая лирическая напряженность создается звуковым строем всего произведения, например повтором резкого, грубого, повторяющегося на протяжении всего текста звука «р» прием «звукового символизма или ономатопеи, который выражен в повторе звука», как пишет Э. Лубинецкий. «Частое повторение звука [p] - [p'] создает тревожную интонацию и является фонетическим выражением ярости, грубости, трагичности» [Лубинецкий 2007: 117].

Стихотворение «Выстрел», вошедшее в число лучших произведений калмыцкой литературы, посвящено памяти инспектора 
службы охраны сайгаков Улдису Кнакису, погибшему в расцвете лет при исполнении служебных обязанностей от рук браконьеров. Стихотворение строится на антитезе беззащитности животного и жестокости человека. Дистантный повтор строк («Что тот, кто нынче выстрелил в сайгака, тот может завтра выстрелить и в нас») в первой части стихотворения, служащей в качестве вступления, обнажает главную мысль автора о том, что суть преступления не меняется от того, против кого оно совершено, будь то растение, животное, человек. Экологические проблемы влекут за собой неотвратимые разрушительные процессы, приводят к нарушению морального здоровья человека и общества.

В «Степной балладе», «Подранке», «Выстреле» поэт создает коллективный портрет бесчинствующих «нелюдей-браконьеров», забивающих сайгаков. Основная мысль этих стихотворений - о необходимости сохранять чистоту нравственных устоев, для того чтобы сохранить и продолжить жизнь на земле. Нравственно-эстетическая позиция автора состоит в утверждении личной ответственности каждого человека за все живое на планете. Природа требует к себе целомудренного отношения - так прочитывается разрешение конфликта человека и природы, и в этом художественная ценность и пафос произведений Д. Насунова.

Поэтому неслучайно, что образы коня, сайгака в произведениях Д. Насунова занимают одно из первостепенных мест.

Согласно традиционным представлениям у калмыков священным животным считался $u$ верблюд. В калмыцком эпосе «Джангар» верблюд Хавшил, «сохраняя космогоническую характеристику», является ужасающим чудовищем, с которым сражается богатырь. Мифы о небесном (часто огнедышащем) верблюде распространены у различных народов Центральной Азии. Так, верблюд считается ездовым животным бога-громовержца (тенгрия). При этом он был едва ли не самым востребованным и полезным животным в кочевом быту. «Верблюд использовался кочевниками самым универсальным способом: молоко и мясо в качестве пищи, шерсть превращалась в ткань и одежду, шкура - в кожу и ремни, 
навоз - в топливо. Можно все передать словом «портативный», созвучный латинской пословице «Omnia mea mecum porto = все свое ношу с собой”, чем мудрость неприхотливости философская знаменовалась. И таков верблюд: зерцало потребности в малом и философской самоудовлетворенности... Кочевник же прост, неприхотлив и аскетичен как верблюд» [Гачев 2002: 7374].

Столь большое значение верблюда в жизни степняков наряду с его мифологическим образом породило уважительное, бережное отношение к этому животному, которое отразилось в фольклоре, обрядах и современной литературе.

В «Балладе о покинутом верблюжонке» Д. Насунова проникновенно, с любовью к народным обрядам старины говорится о принятии верблюдицей своего детеныша. Иногда случалось, что новорожденного верблюжонка отказывалась принять матьверблюдица. Страдания маленького верблюжонка переживались людьми как истинная драма («Проклятая верблюдица! Что делать? / Как верблюжонку малому помочь? [Насунов 1982: 33]). И лишь «бабки... наивные, как дети, но мудрые при этом», находят особый способ побудить верблюдицу принять своего верблюжонка: исполняемая ими грустная песня-плач, вбирающая в себя «печаль столетий целых», тронула за сердце матерь-верблюдицу, и она подпустила к себе детеныша:

Верблюдицу журили до рассвета

Печальной песней, сложенной давно:

Твой верблюжонок едва покрыт пухом,

Он дрожит, и ножки его не окрепли.

Что ты делаешь, верблюдица?

Накорми, приласкай его, опомнись.

Что ты делаешь, верблюдица?

И все вокруг заметно погрустнело:

Околица и жители села,

Как будто бы печаль столетий целых

Одна лишь эта песня вобрала.

Верблюдица внимала ей послушно, 
Застыла, сострадания полна.

Я не был там, но верю тем старушкам,

Что видели, как плакала она... [Насунов 1977: 48-49].

Как отмечает другой калмыцкий поэт К. Эрендженов, описывая этот обряд, грустную колыбельную песню степняки исполняли почти до самого утра. Только к рассвету верблюдица, глубоко вздохнув, с крупными слезами на глазах и дрожа всем телом, подходила к верблюжонку. В это время молодые люди поднимали его и подносили к вымени матери... Верблюдица, приняв родного верблюжонка и накормив его, уходила с ним в степь» [Эрендженов 1990: 29]. По случаю принятия верблюдицей своего детеныша люди устраивали в хотонах своеобразный праздник, веселились от души. Таким образом, опираясь на традиции устного народного творчества, Д. Насунов создает произведение, отличающееся неповторимой национальной самобытностью, проникает в народную фольклорную стихию, отражая при этом вековые традиции монгольских народов.

В стихотворении «Бумба» поэт описывает другой калмыцкий обряд - очищение огнем. Как и все монгольские народы, калмыки относились к огню как к источнику жизни, более того, воспринимали его как живое существо, поклонялись хозяину огня, совершая жертвоприношение чаем, маслом, водкой. Оперение обитающих в степи птиц (дроф) они сравнивали со следами пепла от потухшего костра, оставленного предками-кочевниками, преобразовывая таким образом традиционный для кочевого сознания образ огня. По обычаю перед уходом с места стоянки степняки разжигали в двух местах костры, через которые проходили сами, а затем прогоняли скот. Именно это действо упоминается в «Бумбе».

Уходили калмыки с надеждой,

Что настанет другая пора.

Перед новой кочевкой, как прежде,

Зажигали в степи два костра.

Меж кострами вели караваны,

В пламя гневное сыпали соль... [Насунов 1982: 20]. 
Обряд проводился с целью очищения от действий злых духов, преодоления их негативных последствий и намерений. Добавление соли в костер и возникающий при этом треск и шум призваны были усилить подавляющее воздействие на злые силы. Кочевники верили в то, что невыполнение этого обряда влечет за собой беды и невзгоды. Прием анафоры, используемый в стихотворении, усиливает эмоциональную составляющую и приближает монологический текст к жанру молитвы:

Чтоб не ныли душевные раны, Чтоб остались здесь горе и боль, Чтоб не шла за кочевьем холера, Чтоб не мерла в пути голытьба, И молились, чтоб полною мерой, Оделила их счастьем судьба [Насунов 1982: 20].

Таким образом, творчески осмысляя народные традиции и обычаи, автор воспроизводит подлинную атмосферу жизни народа в недалеком прошлом, давая возможность читателю глубже понять его воззрения, духовные ценности.

В стихотворении «Дядя Федя» говорится о значении калмыцкого чая (джомбы) для степняка. Джомба - традиционный напиток калмыцкой кухни, приготовленный особым образом с добавлением молока, масла, соли, мускатного ореха. Это излюбленный напиток степняка, придающий человеку силы, бодрость духа, согревающий в холода и утоляющий жажду в знойную жару. Много прекрасных слов, посвященных чаю, можно найти в пословицах и поговорках, в сказках, в героическом эпосе «Джангар», а также в произведениях калмыцких поэтов и писателей. Так, в одной из калмыцких пословиц говорится: «Чай, хоть жидкий, — начало всех блюд. Бумага, хоть и тонкая, — начало науки и учения».

В стихотворении «Дядя Федя» тема чая как символа родины вплетена в другую, сквозную для его творчества, тему депортации калмыков: 
И понимал я бабушкину грусть, В тот миг припомнив сказанное ею: «Без хлеба я неделю продержусь, А вот без чая столько не сумею».

А чай входил, он был уже в сенях, И дядя Федя вырос у порога: «Я чай принес. Я был вчера в Ложках, Но, правда, чай надпиленный немного».

Обычай древний бережно храня, Мы созываем всех своих соседей, А чуть в сторонке, греясь у огня, Глядит на нас усталый дядя Федя.

И он о том ни слова не сказал, Со всеми нами радуясь удаче, Что свой паек на чай он обменял, Отдав калоши новые впридачу.

Тот чай калмыцкий, купленный в Ложках, Был словно дождь негаданный в пустыне, Он солнцем грел, и степью он пропах, Кизячным дымом, запахом полыни.

Обычай древний бережно храня, Делили чай ножовкою соседи, А чуть в сторонке, греясь у огня, Глядел на нас усталый дядя Федя [Насунов 1982: 28].

Согласно древнему обычаю кочевников появление любого гостя в кибитке сопровождалось варкой молочного чая, и только после угощения начиналось общение, любые разговоры. Угощение чаем тесно связано со свято чтимой калмыками традицией гостеприимства, ставшей чертой народной культуры и народного ха- 
рактера. Столь же важным и безукоснительно соблюдаемым был обычай делиться любым угощением, а в трудные времена - всем, что ни есть в доме съестного, со всеми, кто рядом (соседями, однохотонцами, случайными прохожими). Повтор строки «Обычай древний бережно храня» акцентирует внимание на гуманности народных традиций, верность которым помогает сохранить лучшие качества души в любых ситуациях.

В стихотворении звучит еще одна тема - нерасторжимость дружеских уз калмыцкого и русского народов. Через метафорическое словосочетание «А чай входил, он был уже в сенях» вводится еще один герой - сибиряк дядя Федя, который, отдав свой паек и «калоши новые впридачу», привозит друзьям-калмыкам подарок - брикет настоящего плиточного чая. На чужбине, в далекой Сибири, чай для калмыка - это символ горячей, неистребимой любви к малой родине, которая ассоциируется с запахами родной степи, кизячного дыма полыни. И русский друг хорошо понимает эту любовь и сочувствует ей.

Стихотворения Д. Насунова («Чуткость», «Дядя Федя» и др.), так же как и посвященные депортации произведения многих калмыцких поэтов - Д. Кугультинова, В. Нурова, В. Шуграевой, С. Байдыева, Е. Буджалова и других — являются отражением незаживающей раны в душе каждого калмыка, а также выражением исторической памяти народа, которая, как писал Д. Н. Кугультинов, «всегда была, есть и будет, пока на земле останется хоть один Человек, ибо Человек без памяти - не Человек».

Тема депортации в творчестве Д. Насунова тесно перекликается с темой Великой Отечественной войны, которая, как уже отмечалось, воспринимается автором через впечатления детства и послевоенной юности, оставившие неизгладимый отпечаток в его душе. Одной из своих задач в освоении данной темы поэт считает изображение и осмысление подвига. Так, стихотворение «Где шли бои» посвящено памяти Эрдни Деликова, первого калмыка, получившего звание Героя Советского Союза, погибшего во время обороны Дона от немецких захватчиков. В произведении отчетливо 
проявляется тенденция внутреннего слияния поэта с образом лирического героя, что придает особую эмоциональную убедительность поэтическому повествованию.

Правдиво и драматично живописуя батальную сцену, Насунов не просто описывает исторические события, но передает сам дух сражения. Он погружает нас в атмосферу войны, густо насыщенную болью, неистовством, ожесточением, страданием, кровью. Силой воображения поэт представляет себя на месте своего героя, каждый нерв и каждая его мысль заняты боем. Мы словно ощущаем тот накал, то напряжение, которое висит в воздухе:

Травой заросшая воронка,

Не шелохнется тишина...

И всем доступна эта сопка,

А для меня идет война.

Я унесен воображеньем

В те полыхающие дни

И сам участвую в сраженье,

Я не Джангар, а я Эрдни.

Вокруг меня гремят разрывы,

И снайпер целится в меня,

И по лицу мне хлещет грива

Стрелой летящего коня.

Потом команда: «По окопам!»

И Дон вздыхает за спиной,

Нет звуков конного галопа,

Лишь рев громадины стальной.

И впереди враги, и справа,

И небо нам - источник зла...

И взбухшей веной переправа

На теле Дона пролегла [Насунов 1982: 22].

Автор раскрывает образ своего героя в его гражданственной, гуманистической сути. Эрдни Деликов предстает носителем высоких нравственных качеств: верности, стойкости, непоколебимой твердости. Это величие проявляется в дерзком бесстрашии, 
в гордом презрении смерти. Готовность идти до конца - это для поэта высшее начало, которое делает человека человеком:

Фашисты прут осатанело -

И кто-то бросился бежать.

Мое искромсанное тело

Хрипит бойцам: - Не отступать! -

Свист бомбы падающей долог,

И надо мной все резче он,

И в сердце бьет мне тот осколок,

Которым Деликов сражен [Насунов 1982: 22].

Через метафорический образ «хрипящего», «искромсанного тела» и фразу «не отступать» автор передает всю жестокость и тяжесть сражения. Убедительно показаны мужество, несгибаемость лирического героя, и шире - нравственная сила человека на войне, проявленная в утверждении справедливости, в защите других от грубого, чуждого, страшного, трагического, от всего того, что несла с собой война.

Описывая подвиг Эрдни Деликова без пафоса, сохраняя верность суровой правде жизни, Д. Насунов считает своей обязанностью рассказать людям о горькой участи тех, кто не дожил до победы. Прием внутреннего слияния с образом героя позволяет передать силу и остроту страдания, боли героя и донести мысль о духовных и нравственных связях поколений, осознании уроков потерь и значении подвига.

В раскрытии военной темы Д. Насунов прибегает не только к описанию событий, но и к воссозданию символических сцен и образов. Так, трагизм войны и ее влияние на души людей психологически точно и тонко переданы в стихотворении «Год сорок пятый»:

Я не забыл, я помню сорок пятый...

Далекое таежное село.

Вот на закате в сторону заката

Упала женщина неловко, тяжело. 
Она, упав, лежала без движенья.

Застывший взгляд и рот полуоткрыт,

И на земле белело извещенье

Со словом убивающим — «убит» [Насунов 1982: 21].

Поэт напоминает, что война - это не только битвы, сражения, фронт, но тыл, ожидания близких, трудовой подвиг женщин и детей. Образ охваченной горем женщины - это, безусловно, олицетворение всех солдатских матерей и вдов, потерявших мужей и сыновей в годы Великой Отечественной, скорбный символ бездны человеческого горя и непоправимых потерь, неизбежных на войне. Эмоциональную напряженность поэтического повествования усиливает эпизод, связанный с проходящим мимо человеком. Он отвергает саму необходимость сочувствия и сострадания, не пытаясь ни понять случившееся, ни помочь. Здесь Насунов поднимает еще одну тему: враждебность войны человеку, сердце которого может ожесточиться, перегореть, не выдержав нравственных нагрузок. В этом тоже, по мнению автора, скрывается обжигающая реальность военных дней - неоднозначное влияние войны на души людей. Таким образом, трагедийное начало, по Насунову, не всегда связано с гибелью героя. Оно - и в искажении морали, нравственности человека, которое приводит к не менее печальным последствиям:

Слоном протопал мимо и изрек:

«У, напилась. Не знает меры, стерва». -

И женщину поднять нам не помог.

А я был хил, и дедушка был старым,

А женщина подняться не могла,

И если был в тот день я санитаром,

Она бойцом израненным была [Насунов 1982: 21].

Описывая случай, возможно, редкий, но по-своему показательный, автор намеренно не конкретизирует, кто был прохожий, он пишет: «какой-то серый тип в тулупе сером», создавая тем самым обобщенный образ бездушного холодного человека. Поэт подчеркивает, что ценность людей во время войны измеряется не только 
выполнением боевых заданий, есть еще одна мера - его нравственные установления, составляющие основу характера человека. Таким образом, особое значение в стихотворении приобретает такая сущностная особенность человеческой личности, воссозданная поэтом, как умение остаться человеком в бесчеловечных обстоятельствах.

В произведениях, посвященных войне, поэт через воспроизведение локальных ситуаций и отдельных душевных переживаний показывает истоки стойкости народа, который в минуту самых тяжких испытаний сохраняет гуманизм, патриотизм, нравственную активность, способность к подвигу.

Д. Насунов обращался в своих произведениях и к более далекому историческому прошлому своего народа, осмысляя его непростую, полную драматических коллизий судьбу. Так, например, в стихотворении «Рандул и Галдан» Насунов рисует жестокую борьбу двух династийных группировок за власть после смерти хана Дондук-Омбо, умершего в 1741 г.

Согласно историческим фактам, умирая, торгутский хан Дондук-Омбо назначил своим преемником десятилетнего сына Рандула от своей второй жены, кабардинской княжны Джан (Жан), дочери кабардинского князя Кургоки Атажукина. После смерти Дондук-Омбо наместником хана стал Дондук-Даши, внук Аюки, и в калмыцких улусах началась борьба за власть. Ханша Джан хотела возвести на престол своего сына Рандула.

Другим явным претендентом на ханство был Галдан-Норбо (Галдан-Нарма), старший сын Дондук-Омбо. Правление ДондукОмбо долгое время сопровождалось постоянными междоусобицами в битве за ханский трон между родственниками.

В произведении Д. Насунова Рандул возглавляет дербетов, его сводный брат Галдан - племя торгутов. Как отмечает Р. Ханинова, историзм стихотворений Д. Насунова служит более художественным задачам, нежели точному воссозданию исторических событий прошлого калмыцкого народа. Примечательно при этом, что поэт обнаружил и озвучил знание структуры этноса. В условиях советской цензуры, когда интерес к проблеме субэтносов не 
приветствовался, это требовало известной смелости и независимости мышления.

Одержимые целью завоевания престола, объятые злобой и ненавистью, братья не прислушиваются к словам своих матерей:

Лязг сабель, визг, воинственные крики,

Один другого в поединке сшиб,

И чей-то вопль взлетел: «Мы все

калмыки!

За что мы друг на друга!»-

долгий хрип...

Побитые лежат на поле брани,

На волжском льду, что искровавлен весь,

Лишь воин одинокий с тяжкой раной

На берег лез, на жесткий берег лез [Насунов 1980: 28].

Изображение битвы воссоздано автором через средства художественной речи: «использование специальной лексики (сабля, воинственные крики, поединок, поле брани, искровавлен, тяжелая рана, копье, убитые), приемов поэтической фонетики - ал-

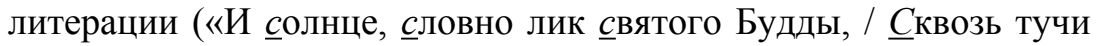
смотрит на убитых их»), консонанса - повтора согласного, заканчивающего слово (лязг... визг; лез... лез), звукового символизма или ономатопеи - семантически окрашенного звукового повтора, создающего «слуховой» образ (выделен в тексте), являющихся фонетическим выражением темы войны, ярости, подчеркивающих жестокость кровопролития» [Лубинецкий 2007: 124]. Ослепленные жаждой власти, ставшие лютыми врагами и до последнего дыхания ненавидящие друг друга, Рандул и Галдан расплачиваются собственной смертью:

Убит Галдан расчетливым орудом ${ }^{1}$,

С копьем в груди Рандул навек затих,

И солнце, словно лик святого Будды,

Сквозь тучи смотрит на убитых их [Насунов 1980: 28].

${ }^{1}$ Оруд - чужой, вошедший. Здесь надо понимать так, что Галдан был предательски убит лазутчиком из вражеского стана 
Р. М. Ханинова, рассматривая данное произведение Насунова, обращает внимание на семантику и символику Волги «как реки жизни и реки смерти, льда как непрочного фундамента семейных отношений, символа племенных распрей и междоусобиц» [Ханинова 2012: 67]. По мнению исследователя, образ Волги способствует углублению главной идеи произведения. «Погибли оба сына, обескровлены два племени, обессилены войска, участвующие в защите южных рубежей Российской империи. Авторская интенция усилена финальным аккордом: турецкий лазутчик нашел убитых братьев на поле брани, отсек им головы, привез своему падишаху и вытряхнул из мешка, как доказательство межплеменной вражды, которая выгодна врагу» [Ханинова 2012: 67-68].

Впечатляющ и символичен на фоне описываемых событий образ солнца, сравниваемый с «ликом святого Будды» («И солнце, словно лик святого Будды, / Сквозь тучи смотрит на убитых их»). Уподобление солнца «лику святого Будды» связано не только с общим для них признаком - «светоносностью» [Лубинецкий 2007: 11], но и с обожествлением, которое приобретает данный космоним (солнце) в картине мира не только буддистов, но и других народов. Так, например, в исламе солнце - око Аллаха, а для славян - символ Христа [Энциклопедия символов 2004: 465].

В традициях Востока солнце это свет Будды, поэтому сравнение солнца и Будды в стихотворении, с одной стороны, отражает сострадание, скорбь по пролитой крови, просветление, вносимое в беспросветную тьму отчаяния, а с другой - связано с буддийскими представлениями о нормах поведения человека. Перечень поступков, от которых должен воздержаться последователь Будды, связан с десятью недобродетелями. В данном случае это, вопервых, недобродетели ума - зависть и злонамеренность, проявляемые в посягательстве князей Рандула и Галдана на престол, в их желании завоевать его во что бы то ни стало, а во-вторых, физическая недобродетель - грех убийства, совершенный обоими братьями на почве алчности и ненависти. Таким образом, идейнонравственная проблематика стихотворения, безусловно, связана с 
буддийской этикой. Напоминание о Будде вносит в стихотворение высокий нравственно-философский смысл, озаряющий духовный свет, в котором особенно удручающим выглядит бездуховное, низменное, пошлое содержание душ погибших героев. Кроме того, образы солнца и Будды, подчеркивая драматизм сюжетной ситуации, с особой силой выявляют основную идею произведения - о трагизме и бессмысленности любой войны, в которой ненависть, ожесточение, звериная злоба, корысть, страсть к власти нередко сталкивают людей, родных по крови, и делят их на два непримиримых лагеря, что неизбежно приводит к гибели обоих. Скорбное солнце, проглядывающее из-за туч, присутствует и в «Слове о полку Игореве». И в этом произведении образ небесного светила, традиционно символизирующего жизнь, подчеркивает трагический конец войны, выражает всепоглощающую тоску и драматизм происходящего.

Еще одна тема, характерная для творчества Д. Насунова, как и для всей советской, в том числе калмыцкой, литературы 1970-х гг., это тема дружбыл, единства между народами. Она звучит в таких стихотворениях, как «Плясал цыган на тротуаре...», «Татарские друзья», «Гости с Кавказа» и другие. С особой полнотой эта тема раскрыта в стихотворении «Украинскому другу», в котором олицетворением «нерушимого» прекрасного чувства выступает образ круга:

Уверенно натянут каждый лук,

И тридцать стрел взлетели в небо вместе.

Воткнувшись в землю, образуют круг

Те стрелы, возвратясь из поднебесья.

В кругу - калмык и добрый гость стоят.

И этот круг — как символ вечной дружбы.

Но позабылся древний наш обряд,

Тугие луки нам уже не служат [Насунов 1982: 47].

Форма круга имеет в калмыцкой культуре особое значение, связанное с солярным культом. Символика круга проявляется в обычаях обязательного обхода (чаще троекратного) по направле- 
нию движения солнца во всех обрядах, в круговом расположении кибиток у кочевников и многом другом.

Описанное в стихотворении действо имеет аналогию с историческим фактом, имевшим место при встрече Петра I и калмыцкого хана Аюки. После вручения Петром Великим золотой сабли Аюке-хану хан приказал лучникам построиться в круг и выстрелить. Стрелы, воткнувшись в землю, образовали круг, и хан поклялся, что эта сабля и стрелы всегда будут готовы к защите Отечества. В стихотворении «Украинскому другу» круговое построение несет в себе высокий смысл единения и защиты. Круг является символом сплочения, укрепления «вечной дружбы» между украинским и калмыцким народами, олицетворением «извечного межнационального круга человеческого братства» [Тартаковский 1991: 43], что особенно подчеркивается в заключительных строках произведения, полных неиссякаемого оптимизма:

Дай обниму тебя, мой добрый друг,

Когда мы вместе, мы непобедимы.

И крепкий круг тебя обнявших рук

Есть символ нашей дружбы нерушимой

[Насунов 1982: 48].

Оригинально и неповторимо входит в поэзию Д. Насунова устное народное творчество. Как правило, обращаясь к фольклорному материалу, поэта использует его в соответствии со своей творческой целью, своими идейными-художественными задачами.

Стихотворение «Джангарчи» основано на осмыслении народной веры в магическую силу героического эпоса «Джангар», в частности в то воздействие, которое оказывает сказитель на силы природы. В произведении намеренно сохраняются все мотивы, присутствующие в древней калмыцкой легенде о старике, попавшем ночью в открытое море и спасшемся благодаря исполнению песни эпоса. Это мотивы хтонического существа (рыба, за которой рыбаки отправились в море), потустороннего мира (возможность 
их гибели в открытом море) и символической инициации, связанной с глубоким даром джангарчи-старика, исполнением им волшебной песни великого эпоса. Однако, сохраняя традиционную сюжетную канву предания, автор вводит в произведение конкретно-исторические имена (хан Аюка), географические координаты (Каспийское море, Лагань, Мангышлак и т. д.), упоминает о славе каспийской рыбы и французского вина и т. д., тем самым делая лирическую картину более жизненной, достоверной.

В другом произведении «Земля моя легендами богата...» поэт, ссылаясь на легенду, якобы поведанную ему джангарчи, рассказывает о том, как в небе появились звезды. Согласно насуновскому повествованию, в период, когда в небесах еще не было ни одной звезды, влюбленный юноша зажег для любимой девушки огромный костер. Искры от него устремились в небо. Так возникли звезды.

Р. Ханинова в статье «О калмыцких легендах в лирике Джангара Насунова», ссылаясь на фольклориста Д. Э. Басаева, упоминает другую известную калмыцкую легенду «Звезды-пуговицы». Исследователь справедливо замечает, что в данном случае обращение Насунова к устному народному творчеству стало «точкой отсчета в авторской интенции», а приведенная в его стихотворении легенда «нигде не зафиксирована», поэтому ее «атрибуция не может быть пока установима» [Ханинова 2013: 68].

$\mathrm{B}$ «Сказке о льстивом тайше, жестоком хане и самой Справедливости» сюжетное действие сводится к тому, что благородный и достойный хан Бембя, при котором сама Справедливость осталась не у дел и заснула, не выдержал искуса лести. Упорному в своем подхалимстве тайше Нарану удается внушить хану мысль о том, что он «самый великий». С этого момента хан из честного, доброго и справедливого превращается в тщеславного и жестокого:

Владыка уверен - он самый!..

И нету честнее его.

Другим заявляет он прямо:

— Нет выше ума моего! - 
Когда же ошибку владыки

Ему же поставят на вид:

— Казнить непокорного! — крикнет

И сам, не моргнувши, казнит... [Насунов 1982: 72].

Автор показывает, какие метаморфозы могут произойти с человеком, стоящим у власти. Активное присутствие авторского «я» позволяет увидеть, что, по сути, хан Бембя сам смастерил веревку, которой его затем и связали. От страха перед упрямым тайшей, приставшем к нему, словно «черная липкая сажа», хан на радость ему занемог. Последующее сюжетное развитие связано с повтором предыдущих событий:

...И хан уже новый хан на троне -

Тот самый упрямый тайша.

А кто-то юлит беспокойно,

У трона кружит, чуть дыша.

— Ты самый! - он шепчет часами... [Насунов 1982: 72].

Через сюжетные перипетии сказки поэт ведет читателя к раздумьям о современной ему общественной жизни. Исходя из того, что решения правителя проходят обсуждение в хурале, в выборном органе верховной и местной власти, можно заключить, что в произведении содержится намек на несовершенство современной чиновничьей среды. Автор заставляет задуматься о нравственной цене побед в ничтожной борьбе за обладание мирской властью. Насунов чутко улавливает дисгармонию современной ему социальной системы, давая понять, что и в ней «достучаться» до справедливости (которая «владыке доверившись, спит») крайне трудно. А тех непокорных, кто не изображает в угоду правителю общее веселье, пытаясь разбудить и установить справедливость, - незамедлительно казнят. И в этом, по мнению поэта, заключается трагизм коллизии, которая присуща и его времени:

По-прежнему весело пляшут

Под пиками те, кто скорбит...

И пляшут, и пляшут, и пляшут,

А тот, кто не пляшет - убит [Насунов 1982: 73]. 
Высмеивая с потаенной скорбью порочность системы, в которой возможен произвол, автор все же верит в справедливость, которая, по его мнению, непременно восторжествует. Обратим внимание в этом плане на итоговый аккорд произведения, связанный с возвращением Справедливости:

Но как-то к владыке под вечер

С докладом заходит тайша:

— К вам девушка хочет... на встречу...

$<\ldots>$

- Кто, девушка юная, будешь?

- А я Справедливость сама. [Насунов 1982: 73].

В небольшом по объему произведении поэт смог соединить лирическое, эпическое и сатирическое начала, предельно остро выразив свою точку зрения на пороки класса власть имущих. Взаимодействие авторского слова с речью персонажей, отражение характера взаимоотношений в общественной жизни, связанных с извечной антиномией правды и лжи, - открывает в произведении интересные горизонты социально-художественных обобщений, скрытые за фольклорной традицией.

Подводя итог, можно сказать, что в своих произведениях Д. Насунов сумел передать традиционные представления о значимых для степняка-кочевника силах, объектах и стереотипах поведения, обусловленных как национальным характером, так и всей духовной культурой народа, что придает его поэзии национальную конкретность и неповторимость.

\section{2. Исповедальная лирика Д. Насунова последнего периода творчества (1978-1979 гг.).}

Джангр Насунов - яркий представитель творческой интеллигенции Калмыкии 1960-1970-х гг. ХХ в. Он был, как отмечает народный писатель Калмыкии Т. О. Бембеев, человеком нелегкой судьбы, сложным и своенравным, прямым, порой резким, незави- 
симым, свободным в своих суждениях и действиях. Поэтому избегал штатных должностей, которые в какой-то мере обязывали человека говорить и писать в заданном идейном ключе. Он работал в редакциях газет, на радио и телевидении, даже в Союзе писателей, но всегда недолго - уходил. Казалось, что Союз писателей - именно то место, где поэт может удачно совмещать работу и творчество. Но не тут-то было. Оказывается, вспоминает Т. Бембеев, там Д. Насунову пытались навязывать чуждую его душе обязанность - прислушиваться к тому, что говорят писатели о своем руководстве. Это побудило его написать заявление об уходе [Бембеев 2000: 2].

Д. Насунов быстро приобрел известность, а вместе с ней возникли трения с окололитературными и партийно-государственными кругами: поэта осуждали за то, что он был слишком резок в суждениях, за то, что не писал на родном языке. Его произведения не получили официального признания. Крайне обостренно восприняв эту коллизию, он так и не сумел найти ее разрешения.

Как уже отмечалось, тот факт, что поэт не писал на родном языке, переживалось им самим как глубокая драма. Метис Д. Насунов всеми силами старался выразить свою национальную идентичность, которая связывалась для него, прежде всего, с глубинным пониманием своих корней, знанием истории, культуры, традиций своего народа, сохранением его нравственных идеалов.

Последние годы жизни поэта (1978-1979) были особенно тяжелыми. На его долю выпало немало неприятностей и трудностей. Д. Насунов переживал творческий и жизненный кризис. Однако он никогда не создавал впечатление побитого жизнью, смирившегося человека, оставался гордым и независимым. Он был не способен на лицемерие и лесть, всегда прямо говорил о том, что его волновало и заставляло страдать. Как отмечает калмыцкий писатель О. Манджиев, Насунов «был резкий в суждениях, резкий в стихах...он писал то, о чем другие молчали, являясь внутренним голосом народа» [Манджиев 1992: 4]. Стремление к правде, справедливости, откровенная непокорная позиция в жизни и творче- 
стве - «это была его внутренняя естественная потребность» [Манджиев 1992: 4]. Близкий друг поэта Джангар Пюрвеев вспоминал о нем так: «Не только в стихах, но и в житейских буднях он был неспособным на лесть и сделки с совестью. Шумный, часто несдержанный, искренне проповедующий свою собственную, выстраданную им самим идею самоотречения во имя любимого дела, он легко наживал себе врагов, но друзья понимали, что все это идет от безжалостности к себе, от каждодневной неудовлетворенности в работе. Но вместе с тем у поэта была легко ранимая душа. Его эмоциональные переживания, напряжение, волнение находили выход в поэзии» [Айтаев 2000: 7].

Стихотворение «Ах, боже мой, куда же лезли вы?», написанное в этот переломный период, содержит глубокий и серьезный подтекст. В нем лирическое «я» поэта открыто проявляет свое нежелание мириться с происходящим. Об этом говорит холодноиронический, уверенный тон, а также риторические вопросы, звучащие в начале стихотворения:

Ах, боже мой, куда же лезли вы?

Вам ли Джангара укротить?

Мое оружие поэзия,

И я сумею победить.

Рычит барбос и лают шавки,

Но дую я в свою дуду.

Уж лучше вы снимайте шапки,

Когда по улице иду.

Уймите шавок лай дешевый:

Я прочно в эту землю врос...

За шавок лай получит снова

Полканов полк и ваш бар-босс.

От вас познал немало горя я.

Снимайте шапки, я зубаст...

За это вам воздаст история,

За лай, конечно, не воздаст.

Ведь я давно уже на лапоть 
И не восторженный юнец.

А, впрочем, все ходите в шляпах,

Но лай умерьте наконец.

На это я имею право -

Меня сжигали вы и жгли...

А я самой России слава

И значит, слава всей земли [Насунов 1990: 3].

Идейно-эмоциональным стержнем стихотворения является «пафос несломленности и преодоления преград» [Кукарека 1992: 14], пафос сопротивления злу, веры в собственную силу и творчество, которая являлась для него смыслом всей жизни, а также единственным «оружием» в борьбе с теми, кто отвергал и осуждал его как поэта, их автор обличает в образе лающих собак («шавок» и «полканов»), во главе которых — «бар-босс». Неприятие его творчества официальной властью вылилось в протест. Лирический герой выступает против установившихся догм, отстаивает свое творчество и, соответственно, свою свободу. В пронзительных и хлестких строках стихотворения просвечивает отчаянная душа самого поэта, ранимая, измученная, наделенная поэтическим прозрением. Лирический герой искренен, правдив и отважен в своем желании сказать о главном. Не получив ни наград, ни покровительства властей, ни официального признания, Д. Насунов тем не менее был очень почитаем в народе, а это являлось для него самым главным в жизни.

Неприятие поэта официальными литературными кругами послужила толчком для написания стихотворения «Петь хотел и хочу без обмана...», передающего состояние его души в трудное время. С первых строк стихотворения раскрываются мучительные переживания лирического героя. Со свойственным ему обостренным чувством правды Д. Насунов пишет о непростых путях и перепутьях творчества, о трудной доле поэта-творца, о борьбе и трагизме современного мира, о сложности и жгучей противоречивости жизни: 
Петь хотел и хочу без обмана.

Только, братцы, по чьей же вине

Я сижу без копейки в кармане

В нашей очень богатой стране?

Нищета, передряги, утраты.

Только пелось и петь я хочу.

Мне за песни недорого платят,

Я за них своей жизнью плачу.

Не считаю себя недотрогой,

Но всегда я боролся со злом,

А талант мой, ребята, от Бога,

Но идут на талант мой с дубьем...

Почему же певцов виноватят?

И зачем превозносят писак?

Ах, ребята, ребята, ребята...

Как же так? Как же так?

Как же так?

Не скажу, что не ведаю страха,

Но в кусты от борьбы не бегу.

Если выпадет в жизни мне плаха,

Умереть я, как надо смогу [Насунов 1990: 3].

Мужественное и беспощадное по своей правдивости стихотворение отражает не только «безысходность и душевный надлом, которые испытывали в то время истинно талантливые люди» [Айтаев 1991: 3]. Это произведение - один из примеров авторской полемики с догматическим сознанием, тоталитарным типом мышления. Наряду с выражением, казалось бы, сугубо внутренних, терзающих сердце переживаний в эмоционально-взволнованных строках проступает авторское отношение к ситуации, царящей и сегодня в нашей стране. По мнению поэта, причины несовершенства установившегося миропорядка, его тотального неблагополучия заключаются не только в социальных, экономических обстоятельствах, но и в деформации человеческих отношений и ценностей. Перед нами сокровенные мысли человека, неравнодушного к судьбе Рос- 
сии, понимающего трагическую неразрешимость противоречий, возникающих в обществе. Использование повтора в заключительных строках произведения («Ах, ребята, ребята, ребята.../ Как же так? Как же так? Как же так?») позволяет выразить боль, досаду, растерянность, гнетущее чувство отчаянья от творящейся несправедливости и всеобщей неустроенности.

Другое стихотворение «Мои печали вслух и немо он рад приветствовать всегда...» (из неопубликованного) поэт адресует своему противнику, который морально его «душил», преследовал и был рад его неудачам. Обращение поэта к нему спокойное, без злобы и гнева. Он твердо знает, что доброта должна выстоять в борьбе со злом и покорить его. И в этом прелесть стихов Д. Насунова, в которых нет ни тени страха. В них сила неприятия зла. Это позиция человека, знающего себе цену, уверенного в своих силах, умеющего преодолевать трудности. Таков сам поэт. Как вспоминает его друг Г. Иванов, он всегда шел своей дорогой, не приноравливаясь к конъюнктуре повседневности:

Мои печали вслух и немо

Он рад приветствовать всегда.

Он даже умер бы на время, Чтоб я скончался навсегда.

Противник мой, ты мне не страшен,

Мне победить тебя - пустяк,

Когда живу светлей и краше -

Хиреешь ты... Какой слизняк... [Насунов 1995: 18].

Непримиримость ко злу, искренность, лукавая ирония, сильная воля, ранимость - все это переплетается как в душе, так и в поэтическом слове автора. Жизненные невзгоды постепенно сообщают его стихам все более напряженную лирическую интонацию. Беспрерывные притеснения душевно изматывали Д. Насунова. Многие стихи этого периода имеют форму исповеди, что придает им исключительный драматизм и напряженность. 
В стихотворении «Бреду без друга и без денег...» отражены отчаяние, смятение и депрессия автора:

Бреду без друга и без денег, Как пес бездомный и больной, И шарф, как порванный ошейник, Как привязь, тащится за мной...

Эй, ты, с блуждающей походкой,

Мне твой финач до фонаря:

Я только так, я с виду кроткий, А в сердце - ярость бунтаря.

Прочь отойди, ханыга бражный, Я - боль сама, я весь в песке...

Не засти свет - на сердце тяжесть

И значит - тяжесть в кулаке...

Сгинь, испарись, ночной отшельник,

Я не таких еще встречал...

А если бить, то бей прицельно,

Под сердце бей, чтоб наповал... [Насунов 1990: 3].

Превалирующими мотивами лирики, определяющими всю структуру художественного мира поэта конца 1970-х гг., становятся гнетущие чувства горечи, одиночества, обреченности, побуждающие к философским размышлениям о смысле бытия, утверждению общечеловеческих ценностей («Бреду без друга и без денег», «Благопожелание» «Ах, боже мой, куда же лезли вы?» и другие). В стихотворении «Благопожелание» чувство острой тоски ассоциируется с иссиня-черным диском солнца:

Есть у солнца цвет определенный

Ярко-золотистый, но подчас

Кажется он иссиня-черным

И тоску усиливает в нас... [Насунов 1982: 53].

Далее мысль о пронизывающей душу человека печали продолжается в афористической форме, народная мудрость органично вписана в художественную ткань произведения, придавая образность и убедительность мысли поэта: 
Средь людей бытует поговорка,

$\mathrm{B}$ жизни ей прописка навсегда:

«Самый белый хлеб бывает горьким,

Если в доме страшная беда»... [Насунов 1982: 53].

Цвет в стихотворении передает состояние душевной депрессии, грусти, горькой печали - когда все цвета переходят в черный, что связано в данном случае с индивидуально-авторской номинацией, глубоко-личными мотивами поэта, а также отражает преемственность литературной традиции. Образ черного диска солнца, передающего настроение боли, смерти, зла, довольно распространен в древнерусской («Слово о полку Игореве») и русской (например, «Тихий Дон» М. А. Шолохова) литературе.

Поэт тем не менее находит в себе силы быть доброжелательным к миру. Обращаясь к «труженикам с честными сердцами», а также ко всему человечеству, он желает всем добра и счастья, при этом эпитеты «иссиня-черный» и «горький» соответственно меняет на «светлый» и «сладкий». Образы «светлого солнца» и «сладкого хлеба», наполненные глубоким позитивным смыслом, являются символами мира и благополучия народа:

Труженики с честными сердцами,

Я хочу, чтоб всюду на земле

Было солнце светлое над вами,

Сладкий хлеб дымился на столе [Насунов 1982: 53].

В последний период творчества в стихах Д. Насунова стало проявляться обостренное ощущение жизненного конца. Об этом говорят его произведения «Сон», «Пробьет мой час, и я во тьму уйду...», «Нам всем отведено так мало дней» и другие. В них поэт осмысливает свою жизнь, констатирует необратимость времени и неизбежность смерти - так в самых общих словах можно выразить содержание его произведений последних лет. Вся суть - в их эмоциональной окрашенности, психологической доминанте. Так, в стихотворении «Сон» автор сравнивает себя с «гонимым ветром» кураем, мятущимся в диком поле. Через этот образ поэт метафорически изображает смерть, создавая тем самым драмати- 
ческую напряженность чувства, передавая свое внутреннее смятение. Ощущение собственной ненужности автор передает через образы «солончака» и «лишая», выступивших «на теле материземли»:

Приснилось мне - я в поле солончак,

Лишай на теле матери-земли,

И от меня встревоженный сайгак

Метнулся прочь, туда, где ковыли.

Мне страшный сон явился в эту ночь -

Кураем $^{1}$ я катился в диком поле.

На миг замру и снова - прочь,

И эта воля хуже, чем неволя... [Насунов 1982: 52].

Сон - это способ скрыться от наскучившей реальности, ощутить свободу, почувствовать себя безмятежным. Однако в данном случае ледяное предчувствие смерти охватывает героя именно во сне, после которого следует неприятное пробуждение, он испытывает страх перед ее неизбежностью:

Проснулся я, а за окошком рай...

Но в страхе сжалось сердце почему-то.

Гонимый ветром, мечется курай,

И нет ему ни счастья, ни приюта [Насунов 1982: 52].

Призрак смерти пугает героя, ведь ему присуще обостренное чувство жизни, он знает и понимает ее истинную, ни с чем не сравнимую ценность.

Жизнь воспринимается лирическим героем как умение любить и растворяться в природе, как величайшее счастье и источник радости, любовь к ней воплощается в стремлении поэта «увидеть весь земной шар». В стихотворении «Как хочется увидеть шар земной», составляющем, можно сказать, квинтэссенцию мироощущения поэта, несущем мощный заряд вдохновенного всеобъемлющего жизнелюбия, герой ощущает дыхание жизни в окружающем его мире, во всей его конкретности и целостности: в

\footnotetext{
${ }^{1}$ Курай — перекати-поле.
} 
«ручейках и горах», выражающих органичность единства человека с природой, в детях, которые являются символом будущего, в женщинах, выступающих олицетворением любви. Жизнь, по Насунову, оправдана тем, что в ней присутствуют добро, красота и гармония, возвышающие душу:

Как хочется увидеть шар земной,

Все уголки, все ручейки и горы,

И всех детей, всех женщин до одной,

Но смерть не отменяет приговора:

Пробьет мой час, и я во тьму уйду,

Где ни степей, ни лепестка, ни стебля...

Хотел бы превратиться я в звезду,

Чтобы всегда глядеть на нашу землю...

[Насунов 1982: 52].

Джангр Насунов - утонченный лирик, наделенный, безусловно, божественным даром поэта. Лирика его эмоциональна, богата в передаче оттенков и переливов души. Поэт отличается тонким восприятием жизни, умением запечатлеть и воспеть прекрасное. В стихотворении «С годами мы грубеем почему-то...», сильном, как молитва, по эмоциональному накалу, ярко выражено жизнелюбие поэта, его восхищение окружающим миром:

С годами мы грубеем почему-то.

Иль, может быть, грубею только я.

Но даже в очень горькие минуты.

Я ощущаю радость бытия...

Все это жизнь. Я в это очень верю,

Всем восхищаюсь и люблю.

О, жизнь моя, умерь мои потери,

Продлись до бесконечности. Молю [Насунов 1994: 4].

Таким образом, жизнь и смерть в поэзии Д. Насунова неразрывно связаны между собой и осмысливаются автором поособому: в его сознании они постоянно находятся рядом и, трансформируясь друг в друга, фактически оказываются равными. 
Душевная ранимость, обостренность чувств, постоянные переживания по поводу отчуждения, неприятия, с которыми поэту приходилось сталкиваться, наложили свой отпечаток и на его любовную лирику. Любовная лирика Насунова проникнута глубочайшим психологизмом, подлинной человечностью, чистотой и благородством сложнейших душевных переживаний. Любовь воспринимается им как высшая ценность, как самое чистое, прекрасное, подлинно глубокое и всепоглощающее чувство. По сути, это исповедальная лирика, где образ любимой лишен признаков конкретного человека. Упоминаются лишь некоторые черты («черные глаза», «грозный взгляд»), через которые как бы передается ее характер: гордая, строптивая, честолюбивая. Однако только она способна рождать в душе поэта высокие чувства и вдохновение.

С тихой затаенной грустью в стихотворении «Где вы теперь? Как много дней прошло...» Д. Насунов пишет о своей первой любви, вспыхнувшей яркой звездой, но, увы, не продлившейся в его судьбе. Она вспоминается им в зрелости, когда уже пришли опыт и мудрость, знание жизни. Однако прошедшего не вернуть. Воспоминания приносят лирическому герою сладостное томление, потому что сердце все еще любит, страдает и мучается.

$\mathrm{Bce}$, написанное поэтом, пропущено через сердце, связано с его биографией, личными переживаниями, духовным опытом, поэтому его стихи так близки и понятны читателям. В стихотворении «Искал себе женщину лучше...» лирический герой страдает от того, что любовь к женщине, у которой он не находит понимания и поддержки в трудные моменты жизни, не дарит ему ощущения полного счастья, не окрыляет его на покорение новых вершин, более того, такая любовь приносит боль и душевную муку. Возлюбленная оказалась не той, с кем он надеялся провести спокойную жизнь, полную творческого труда и тихих семейных радостей:

Искал себе женщину лучше,

Казалось, нашел, но увы.

Стою, закручинясь, на круче,

Совсем невезучий в любви. 
Уже тяжелеет походка

Не только от прожитых лет.

Я нынче похожий на лодку,

Где весел и паруса нет.

Не чайка кричит над волною -

То плачет средь белого дня

Мечта, что рассталась со мною,

И кружит, покинув меня.

Пустым, бесталанным я числюсь

И лишним в степной стороне.

Все эти тяжелые мысли

Внушила та женщина мне.

Стою, закручинясь, над кручей,

И Маныч под кручей рычит.

Я очень в любви невезучий,

И чайка кричит и кричит... [Насунов 1982: 63].

Разочарование, осознание того, что любовь ушла, рождает чувство одиночества, безысходности. В этом смысле показательна лексика стихотворения, передающая исключительную напряженность лирического переживания: «закручинясь, на круче», «совсем невезучий в любви», «тяжелые мысли», «увы», «плачет», «лишний», «пустой», «бесталанный», «рычит» и другие. Мотив разочарования в любви, возможно, связан с неблагополучно сложившейся семейной жизнью самого поэта, сложными взаимоотношениями с любимой женщиной.

Поэт неслучайно вводит образ лодки без весел и паруса, который передает трагизм, предельную напряженность и горечь переживания лирического героя. Лодка в калмыцких новогодних обрядах, совершаемых во время буддийского праздника Зул, является символом течения времени и жизни человека. Образ кричащей чайки символизирует разлуку, мучения, томление, несостоявшие- 
ся мечты и надежды героя. Таким образом, именно через образы лодки и чайки передается состояние души самого поэта - страдающего, надломленного, одинокого.

Безусловно, любовная лирика Д. Насунова субъективна, личностна. Истинное чувство любви выражено неоднозначно. С одной стороны, оно предстает как возвышенное, всепоглощающее чувство великой силы, а с другой - приносит душевные мучения, причиной которых оказываются безответная любовь либо разочарование в любимом человеке, разлука. Даже в самых своих глубоких и искренних проявлениях любовь в лирике поэта неотделима от страдания.

Ощущение разлада с самим собой, щемящая тоска не только составляют характерные, превалирующие мотивы лирики Д. Насунова, определяют структуру его художественного мира конца 1970-х гг., но и являются одной из причин смерти поэта. Изнуряющее ощущение безвыходности доводят его до самой крайней степени отчаяния. Этому поспособствовали и затевавшиеся против него интриги, враждебное отношение к его творчеству. Поэт ушел из жизни в возрасте 37 лет, молодым, талантливым, на самом взлете поэтического самовыражения. Его не стало 14 марта 1979 г. И до сегодняшнего дня его уход необъясним, невероятен, загадочен. Имя Джангра Насунова замалчивалось более десяти лет после его трагического ухода. И лишь в начале 1990-х годов был снят негласный запрет на имя и творчество поэта. В газетах и журналах Калмыкии стали появляться произведения калмыцких поэтов, посвященные его памяти. Назовем некоторые из них: стихотворения А. Баирова «Памяти Джангра Насунова», «Задумчивый старый парк», «Ненадолго дожди отступили»; В. Чонгонова «Я чуть-чуть подожду»; Ю. Курбатов «Вы скажете...»; А. Санджиева «Джангру Насунову». Признание и любовь читателей поэт завоевал еще при жизни, став выразителем истинных и лучших устремлений мысли и чувств своего поколения. В его стихах звучит непоколебимая вера в свое духовное бессмертие: 
...Пробьет мой час, и я во тьму уйду,

Где ни степей, ни лепестка, ни стебля...

Хотел бы превратиться я в звезду,

Чтобы всегда глядеть на нашу землю [Насунов 1982: 52].

Отражая в своем творчестве народные традиции, особенности национального мировосприятия, поэт в то же время вбирает в себя опыт русской классической литературы, составляющей «большу́ю часть духовной культуры калмыцкого народа» [Пюрвеев 2001: 78]. Как верно отмечает В. Сидоров, в его стихах «...четко обозначена тенденция времени, направленная на сближение, на взаимное обогащение культур народов нашей многонациональной страны. Калмык по рождению, он писал на русском языке. Он работал - и работал вдохновенно - на стыке русской и калмыцкой литератур. Две традиции, творчески осваиваемые поэтом, даровали его стихам свежие краски, даровали им своеобразие» [Сидоров 1982: 3]. Преобладающее воздействие на художественное мышление калмыцкого русскоязычного автора оказало творчество Сергея Есенина. Он был любимым поэтом Джангра Насунова, что хорошо подтверждают следующие строки:

...3дравствуй, друг мой ласковый и нежный.

Тихий дождь, ты о любви рассказ,

Что без слов, но каждому понятный.

Я такой хороший в этот час

С чувством всепрощенья необъятным.

Через все года тебя несу,

Становлюсь теплей, как только вспомню -

Тихий дождь в березовом лесу,

С листьев струйки брызжут на ладони...

Тихий дождь в березовом лесу...

Ствол березки трогаю рукой

И шепчу есенинские строки.

Ты продлись подольше, мой покой -

Редкий гость, пришедший издалека...[ННасунов 1982: 62]. 
О близости есенинской поэзии духовному миру Д. Насунова пишет и Э. В. Лубинецкий. Исследователь отмечает, что эта близость проявляется «в неравнодушии к судьбе Родины, глубоком сострадании ко всем людям, горьких раздумьях, об окружающей действительности, о человеческих взаимоотношениях. Сам строй, мелодика, стиль стихов Д. Насунова, мотив единения с природой, «половодье чувств», тонкая эмоциональность лирики, сопровождаемая своеобразной русской грустью, напоминают поэзию С. Есенина [Лубинецкий 2006: 130]. Особенно проникновенно в этом смысле стихотворение «Раздумья в пути...»:

Вы очень, Сережа, на всех непохожи,

Сережа, вы свежий, как первый снежок...

На вас быть похожим так сложно, Сережа;

Вы нежный, и в этом, как небо, высок.

А я огрубел, весь измят, искорежен,

И этих не принял, отринул и тех,

Как дальше мне жить, подскажите, Сережа,

Российский поэт, самый русский из всех?

Россия, Сережа, бурлит постоянно,

Сражения всюду, хоть нет баррикад,

Но к тем, что правы, я никак не пристану,

Никак не улажу свой прежний разлад...

Пейзаж за окошком, осенний, неброский,

И лету вернуться уже не дано.

Оплачет листвой золотистой березка,

Поэта Руси и меня заодно [Насунов 1994: 3].

Отражение в творчестве Насунова лучших традиций русской классической поэзии свидетельствует о «диалогической встрече двух культур», являющейся, по мнению М. М. Бахтина, универсальным явлением, «пронизывающим все отношения и проявления человеческой жизни, вообще все, что имеет смысл и значение» [Бахтин 1975: 56].

Лирика Д. Насунова отличается необыкновенной силой искренности, возвышенностью, лирической исповедальностью. Пи- 
сатель Т. О. Бембеев справедливо отмечает, что поэт писал размашисто, колоритно, в ритмах, близких самой жизни. «Его стихи - стихи человека несомненно одаренного, свободно владеющего словом, с новизной почерка, свежестью взгляда, когда поэзия идет от конкретного, пережитого. Это не «голые пейзажи» и не умозрительно холодное философствование, а стихи, в которых переливаются яркие краски жизни, где постоянно присутствует человек, его настроение, мысли» [Бембеев 2000: 8].

\section{$* * *$}

Анализ поэзии Д. Насунова показывает ее глубоко народные истоки, что не только является следствием развитого национального самосознания, но и отражает стремление поэта выразить свою этническую идентичность через нравственно-эстетический опыт калмыцкого народа, через знание его истории, культуры и психологии. Национальное своеобразие Д. Насунова просматривается как на тематическом, так и на микроуровне. Выбор тем обусловлен и связан с историей и культурой калмыков, их обычаями, традиционной системой взглядов. На микроуровне калмыцкая национальная словесно-художественная картина мира создается благодаря использованию традиционной народно-образной символики - образов степи, коня, верблюда, сайгака и т.д., являющихся внешним, материальным миром вещей, окружавших степняка-калмыка и формировавших его художественное сознание. Поэт мыслит этими категориями, выражает через них целостность кочевого времени-пространства, отражает «свое отношение к явлениям жизни» [Гармаева 1988: 3-21]. Каждый основополагающий образ несет определенную смысловую нагрузку, восприятие этих поэтических концептов в совокупности составляет единый образ Родины, являющийся доминирующим для постижения калмыцкой национальной словесно-художественной картины мира. Так, например, степь для калмыка в понимании автора - родной дом, и потому в его стихах она является сакральным местом, где лирический герой обретает покой, полноту жизни, гармонию с 
окружающим миром. Образы полыни, тюльпана также традиционно ассоциируются с малой родиной («Запах полыни», «А Маныч манит здешних и нездешних», «Тишина», «Вдали ворчит, рыдает Маныч...» и др.). Поэт ощущает духовное родство, удивительную близость ко всему, что его окружает, именно поэтому все перечисленные «константы мировидения», символические образы имеют для него сокровенный характер, а «народные обряды, легенды, пословицы в произведениях создают новую поэтическую модель, далекую от мажорно-оптимистической интонации и самоуверенности первых десятилетий XX в. <..> глубокое проникновение в народнопоэтическую мысль - безусловная заслуга художника, который сумел извлечь смысл народной мудрости и растворить его в своей поэзии» [Салдусова 2012: 5].

«Джангр Насунов - поэт, выразивший мировосприятие поколения, утратившего всякие иллюзии, но не потерявшего генетической связи с предками, которая дает опору в понимании изначальной разумности мира, его целесообразности. Эта верность сохраняет зерно исторического оптимизма» [Салдусова 2012: 5]. Национальное, народное начало составляет нерв поэзии Джангра Насунова. 


\section{ГЛАВА ІІІ. ВЗАИМОДЕЙСТВИЕ ВОСТОЧНЫХ И ЕВРОПЕЙСКИХ КУЛЬТУРНЫХ ТРАДИЦИЙ В ПОЭЗИИ Р. ХАНИНОВОЙ}

\section{1. Поэзия Р. Ханиновой в аспекте диалога}

Среди русскоязычных поэтов Калмыкии современного поколения заметно выделяется фигура Риммы Михайловны Ханиновой (р. 1955 г.). Будучи калмычкой, языком своего творчества она избрала русский язык, хотя родной, калмыцкий, знает в совершенстве. В выборе языка сказались понимание тенденций развития общества и желание рассказать всему миру о судьбе и культуре своего народа. Посредством языка межнационального общения Р. Ханинова выносит поэзию своего народа на международный уровень, развивая таким образом диалогические отношения между калмыцкой литературой и литературами народов России, — то, что мы называем диалогом культур. Автор обрела широкую читательскую аудиторию, известна и за пределами России: поэзию Р. Ханиновой знают в США, во Франции, Швейцарии, Иране и Черногории. В ее творчестве переплелись калмыцкая и русская культуры, соединились два языка, две поэтические традиции. В отношении ее поэзии уместно утверждение К. К. Султанова о том, что в «сопричастности к двум великим национальным космосам коренится широта мировоззрения и кругозора автора, исключающая духовный провинциализм и герметизм» [Султанов 2001: 1].

Выбор Р. Ханиновой русского языка как языка творчества, во-первых, связан с развивающимся русским монолингвизмом в Калмыкии, во-вторых, обусловлен самим процессом духовноэстетического формирования и жизненного становления Ханиновой, сильным воздействием на ее художественное развитие прежде всего русской культуры. Римма Михайловна - филолог, преподаватель, специалист по русской и калмыцкой литературе. Ее поэтические произведения постоянно публикуются на страницах республиканских и городских газет, журналов. Стихи из цикла «В тени Конфуция» представлены в переводе А. Бурыкина на англий- 
ский язык в международном журнале поэзии «Icefloe» (2002 г.). Произведения автора вошли в Антологию литературы народов Северного Кавказа (Т. 1: Поэзия. Ч. 1. Пятигорск, 2003), словарная статья о творчестве Р. Ханиновой опубликована в энциклопедическом монгольском словаре (Т. 1: Литература. Хух-Хото, 1992. C. 350).

Р. Ханинова - поэт по призванию. Стихи начала писать в детстве, продолжила в школе, а затем в университете. Первые публикации в прозе (рассказы) относятся к 1972 г. («Сургаль», «Братья сели в чудесное седло сургали»), в поэзии - к 1989 г. Становление Ханиновой как поэта пришлось на 1970-е гг., когда она училась в Калмыцком государственном университете на филологическом факультете. В 1993 г. увидела свет ее дебютная книжка «Зимний дождь», год спустя - сборник «Взлететь над мира суетой». В сборнике калмыцкой женской поэзии «День влюбленных» (1997) ее стихи заняли отдельный раздел «Шепчущий мост». В 2002 г. появился сборник стихов и поэм «Час речи», изданный к 80-летию отца, классика калмыцкой литературы Михаила Ванькаевича Хонинова и посвященный его памяти. В эту книгу вошли как переводы произведений отца, так и собственные произведения. В 2005 г. в соавторстве с литературоведом, литературным критиком И. Ничипоровым был издан сборник стихов, поэм, эссе «На перекрестках Софии и Веры...». В 2010 г. к 90-летию М. Хонинова вышел совместный сборник «Красный тюльпан», в который вошли стихотворения и поэмы отца, собственные произведения, а также очерки, статьи, заметки и стихи других поэтов, посвященные М. Хонинову. Р. Ханинова - автор книжек стихов для детей «Умная мышка» и «Буква А» (библиотечка журнала «Байр», 2002, 2010). В 2011 г. в журнале «Теегин Герл» опубликована ее первая пьеса «Легенда о джангарчи» (2008).

Обращает на себя внимание вдумчивое отношение автора к своим книгам, как к их содержанию, так и к оформлению. Поэт скрупулезно формирует сборники, выделяя тематические разделы и циклы. Так, дебютный сборник «Взлететь над мира суе- 
той» включает в себя шесть разделов «Автопортрет», «Талисман», «Подкова над отчим порогом», «Автограф», «Ночная трава», «Наследство». В разделах, в свою очередь, выделяются тематические циклы. Например, раздел «Талисман» включает цикл «Восточные мотивы», а раздел «Наследство» составляют циклы «По мотивам буддийских басен» и «По мотивам индийских легенд». Кроме того, Р. Ханиновой свойственно бережное отношение к датировке своих произведений. Как отмечает А. А. Бурыкин, для нее это «не просто хронология (реже топонимика) создания, а важный элемент рамочной конструкции в интерпретации текста» [Бурыкин 2005: 100].

Р. Ханинова - поэт с ярко выраженной индивидуальностью. Ядро ее творчества, очарование поэтического стиля проявляется в необычном и органичном сочетании литературных традиций Запада и Востока. Об этом говорит и сам автор: «Во многом на меня идет влияние евроазиатское во всей его совокупности...Стараюсь придерживаться принципа многотемья и многожанровости...» [Ханинова 1993: 2]. Однако, как отметил В. Э. Очир-Гаряев, «... дело не во множестве охваченных тем, не в наборе стрел в «колчане», а в раздумчивости стихов Риммы Ханиновой, в их значимости и нужности» [Очир-Гаряев 1998: 119]. Параллельно осмысливая два языковых мира, поэт сумела создать на русском языке поистине национальную поэзию, глубоко отражающую самосознание, ментальное мироощущение, традиции калмыцкого народа. В данном случае можно говорить о бикультурности творческой личности, для которой свойственен диалогический тип выражения.

То, что поэт находится на стыке двух национальных культур, несомненно, отражается в ее творчестве. Так, обращение к мифологическому наследию, культурфилософским парадигмам Востока, его ярким краскам и образам (японские сказки, буддийские притчи) соседствует в ее стихотворениях с европейскими поэтическими канонами и обертонами. Приобщение к мировой западной и русской классике (Л. Сенека, Ф. Петрарка, А. Пушкин, Б. Пастернак, А. Блок, С. Есенин, М. Цветаева и др.) столь же глу- 
боко, как и знание традиций калмыцкой народной лирики, творчества калмыцких поэтов - предшественников. Знание устного народного творчества и обращение к буддийской аксиологии (поэмы «Час речи», «Все движет Женщина-Любовь», «Солнечный Лев», стихи «Монах тибетский пред собой метет...» и т.д.) сочетаются со знанием мифологического наследия разных народов (поэмы «Формула судьбы», «Справедливый И»). Все это способствовало формированию таланта автора, нестандартности ее поэтического образа, расширению поэтического диапазона.

Главное отличительное свойство поэтического творчества Р. Ханиновой - диалогичность. В нем присутствуют «диалоги как отклик на цитату, расширение или дополнение близких ей идей. < ..> диалог поэта и литературоведа, диалог цивилизаций и поэтических миров (И. Бродский, Б. Пастернак), диалог поколений, времен минувших и грядущих, отца и дочери, над всем этим стоит диалог Запада и Востока» [Дампилова 2010: 204]. Как верно отметил А. А. Фокин, «каждое слово этого поэта - это реплика диалога, заключающая в себе смысловой избыток, тайну и, не побоимся сказать словами великого Гете, «иррациональный остаток». В этом, с одной стороны, видятся истоки читательской востребованности и популярности поэзии Р. Ханиновой, а с другой причины необходимости перевода ее образных смыслов на необразный, дискурсивный язык, то есть филологического осмысления «целомудренной бездны» ее стиха, но не ради критики-оценки, а ради критики-понимания» [Фокин 2005: 12].

Один из главных поэтических диалогов в творчестве Ханиновой - это диалог с отцом, известным калмыцким писателем М. В. Хониновым, оказавшим решающее влияние на формирование ее как поэта.

Судьба отца, неразрывно связанная с судьбой его поколения, пережившего одну из трагических и героических страниц в истории калмыцкого народа, в творчестве Р. Ханиновой является отдельной темой разговора. Он служил для нее «живым примером человеческой и творческой цельности» [Ханинова 1993: 5]. От 
отца дочь получила своего рода эстафету и благословение на творчество, а его литературный труд понимает как пример беззаветного служения людям. Духовное соприкосновение двух художников выражается не только в словесном диалоге, который происходит, в частности, благодаря литературной цитации Ханиновой строк из произведений отца - в качестве эпиграфов и включений в собственный стихотворный текст. Контакт миров в «ином - вербальном - измеренье» [Ханинова 1994: 69] выражается, прежде всего, в единстве этических и эстетических воззрений, в идее преемственности духовных традиций, в равно бережном и творческом отношении к фольклору, в общности философских подходов к явлениям жизни и поискам истины.

Р. Ханинову с детства окружала писательская среда. Будучи литературным секретарем отца, она помогала ему в работе: печатала на двух языках, редактировала, занималась корректурой, вела переписку. Впоследствии, уже после смерти отца, Римма Ханинова опубликовала неизданное из его литературного архива и, самое главное, перевела на русский язык его поэмы: «Почему у Совы нет ноздрей» (1998), «Сказание о калмычке» (1998-1999), «Чигян - пища мира» (2005), «Мой путь» (2006), а также стихотворения: «Веревка-няня», «У каждого своя звезда на небе», «На небе альчики рассыпала луна...», «На руке одной», «Седло», «Стану красным тюльпаном», «Три ответа» и многие другие.

Внимание к творчеству отца, безусловно, не могло не отразиться на формировании поэта Риммы Ханиновой. В своих произведениях она постоянно апеллирует к признанному мастеру слова как на идейно-тематическом уровне, так и на уровне образной символики.

Диалог двух поэтов особенно явственно звучит в совместном сборнике «Час речи» (2002), изданном к 80-летию со дня рождения М. В. Хонинова и посвященном его памяти.

«Час речи» представляет собой не просто книгу, в которой под одной обложкой напечатаны стихи двух поэтов, связанных узами родства и представляющих творческую династию. Можно согла- 
ситься с А. А. Бурыкиным, что «это глубокий по содержанию диалог поэтических мировоззрений с неизбежными контрастами их во времени, идеологии, языке, стиле, форме и других атрибутах поэтического ремесла» [Бурыкин 2004: 107].

В сборник включены программное стихотворение М. Хонинова «Красный тюльпан» и поэмы «Почему у Совы нет ноздрей», «Сказание о калмычке», переведенные на русский язык дочерью.

Творчество Р. Ханиновой представлено избранными стихотворениями из циклов «Разговор с отцом» и «Сибирской памяти тетрадь», а также поэмами «Час речи», «Все движет ЖенщинаЛюбовь», «Солнечный Лев», написанными по мотивам калмыцких легенд, сказок и преданий и «пробужденными», как отмечает сам автор, отцовскими поэмами. Таким образом, в книге состоялся дебют Р. Ханиновой как в области художественного перевода, так и в жанре поэмы.

Основные идеи книги «Час речи» - верность памяти предков, сохранение преемственности традиций, единство человеческого сообщества, связь времен и поколений, прошлого и настоящего. Источником творческого сопряжения выступает историческая память. Неслучайно книгу открывает стихотворение М. Хонинова «Красный тюльпан», в котором звучит глубоко философская мысль о человеческой жизни, вечности и бренности бытия, преемственности поколений:

Коль наступит мой час, - вы запомните, дети:

Я не лягу в земле мертвецом бездыханным.

Буду каждой весною в трепещущем свете

Подниматься на родине красным тюльпаном.

Вы запомните, дети, поведайте внукам,

Что их дед не тоскует под настом песчаным,

Что он тянется к жизни, к волнующим звукам,

Что в степи возродился он красным тюльпаном

[Хонинов 1978: 54].

Михаил Матусовский писал, что стихи М. В. Хонинова больше, чем просто литература: «...в них наглядно видно, как поэзия и 
жизнь соединяются воедино и где, совсем по-пастернаковски, кончается искусство и дышит почва и судьба...» [Матусовский 2010: 659]. «Каждую страницу своих талантливых книг он не только создал как самобытный художник, но и пережил как человек яркий, мужественный и честный» [Санджиев 2010: 702-703]. Поэтому творчество калмыцкого поэта, рано ушедшего из жизни, - это духовное завещание народу. Он - один из тех, кто своим творческим трудом продвинул вперед калмыцкую литературу, раздвинул ее горизонты. Пройдя большой жизненный путь, накопив богатый опыт, размышляя о ценности прожитых лет и духовном бессмертии человека, поэт писал:

Кто людям

отдавать себя привык,

Другой судьбы тому

Желать

не надо... [Хонинов 1981: 188].

Духовное завещание М. В. Хонинов оставил и своим детям:

Жизнь - эстафета,

как коня,

Я детям передал, ценя,

Дар предков...

Мчитесь дальше, дети [Хонинов 1977: 56].

Желание принять «эстафету» и достойно оправдать миссию дочери замечательного калмыцкого художника слова диктует Р. Ханиновой следующие строки: «Как сохранить потребность этой веры / Преемственность в наследии отца?» [Ханинова 1994: 73].

В стихотворениях-посвящениях М. Хонинову слышится дочерняя любовь и гордость за легендарного отца. Римма Ханинова, считая себя преемницей отца и продолжательницей его творческих традиций, чувствуя себя в неоплатном долгу перед ним, стремится усвоить его жизненные и литературные уроки, сделать достоянием народа его литературное наследие, несущее огромный заряд духовности: 
Твердят, что я в отца и внешностью и нравом, как хочется, чтоб в том все оказались правы: нет лучшей похвалы и лучшего призванья в том, чтоб достойной стать подобного признанья. Старалась быть отца я правою рукою, постичь суть ремесла, представшего судьбою, понять основу тайн в том сокровенном слове, дающем жизнь всему, осмысленному внове...

[Хонинов, Ханинова 2002: 13].

Стихотворения Р. Ханиновой, посвященные памяти отца, звучат как отклики на его стихи. На всех уровнях организации ее произведения принципиально разомкнуты в контекст и только так существуют во всей полноте художественного смысла. Как верно отметила М. Петрова, в них автор разворачивает заданные отцом-поэтом темы и образы. Сама Римма Ханинова пишет, что стихи, «посвящение светлой памяти отца - попытка остановить Время: я разговариваю с поэтом» [Хонинов, Ханинова 2002: 11]. Здесь обращает на себя внимание использование такого явления, как литературная цитация. Как уже отмечалось, Римма Ханинова берет в качестве эпиграфов строки из произведений поэта-отца, а затем творчески переосмысляет их в своем тексте, перекликаясь при этом на уровне тем, мотивов и образов со многими его стихотворениями.

Творческое сопряжение двух авторов происходит в рамках различных сюжетов и тем. При этом общие начала их творчества - гуманизм, мощный интеллектуальный накал, глубина философского мышления. Широкий спектр тем сводится, по сути, к выражению сокровенной сути человека, к духовному, нравственно-этическому облику современника, к пониманию его жизни, назначения и пребывания в мире, бесконечного поиска себя, преемственности традиций и поколений («Красный тюльпан», «Твердят, что я в отца и внешностью и нравом», «Степные колыбельные мотивы», «Завет отцовский непреклонен», «На фото выцветшем застывшее мгновенье» и др.). 
Объединяющим началом в творчестве обоих авторов также является интерес к духовному наследию своего народа, выражению мира народной культуры, духовных традиций, стремление опереться на исконно национальное начало, уходящее своими корнями в глубь истории, в фольклор. Так, свою генетическую принадлежность к народной стихии М. В. Хонинов выражает, во-первых, через традиционный образ степи, которая для его лирического героя является тем пространственным состоянием, с которым он родился в лоне своей культуры. Второй по значимости - образ коня, органичная составляющая бытия кочевника. Без него немыслимо полное слияние степняка с миром, невозможно динамичное направление, его постоянная устремленность в пространство. Это чувство свободы существовало и продолжает жить в восприятии калмыка.

Знание своих истоков, корней, кровного с ними единства как духовной высоты является отличительной чертой национальной поэзии М. Хонинова, за плечами которого был опыт расставания с родиной и обретения ее вновь. Этот опыт рождает новые смыслы, например новое чувство фундаментальности, основы, устойчивости бытия у его лирического героя, которое дает ему родная земля.

В степи калмыцкой я родился. Мне

Она была конем и колыбелью [Хонинов, Ханинова 2002: 15].

Эта же глубоко национальная модель мира, в которой комфортно степняку-кочевнику, развернута и подхвачена Р. Ханиновой, для которой «степь как мать в заботе терпелива» [Хонинов, Ханинова 2002: 15]. Символы кочевого пространства поэт словно соединяет в единое семантическое целое. В результате в создаваемом образе ощущается тепло и энергия Вселенной:

И в том полете каждого коня,

как тетивой натянутой стрела,

и время и пространство бытия

в конечной цели встретятся, пока

свой цикл не повторит Земля [Хонинов, Ханинова 2002: 15]. 
Стихотворение Риммы Ханиновой «Отцовский завет» представляет собой художественное кредо поэтессы и служит своеобразным эпиграфом ко всему ее творчеству:

Завет отцовский непреклонен:

дерзай, будь стойким до конца,

как куст полыни неприкаян

под жестким прессингом коня,

когда его копыта в землю

загнать траву стремятся вниз.

Но вновь упрямая не внемлет -

опасности наперекор -

встает в который раз упорно

и тянется руками ввысь;

как средостение меж недрами и небом

(как «дышит почва и судьба», — он прав, поэт!),

как дар, ниспосланный

животворящим хлебом, -

в том поединке пораженья нет! [Ханинова 1994: 81].

Это стихотворение - отклик на произведение М. Хонинова «Ожидание» (пер. И. Волобуевой). Лирический герой перед операцией в московской клинике вспоминает давнюю историю о степнячке, укрощавшей коня. Образ полыни «под жестким прессингом коня» метафорически воплощает сильную волю, непоколебимость и стойкость духа. Неслучайно в монгольской литературной традиции образ полыни, как отмечают исследователи, «символизирует несгибаемую силу воли кочевых племен, сумевших сохранить свое имя и честь в неравных битвах за земное бытие» [Дампилова 2010: 73]:

Мне казалось тогда, что калмычка та, в облаке пыли, Вправду в черта вцепилась, держась еле-еле в седле.

И запомнился мне синеватый тот кустик полыни, Что дрожал меж копыт, прижимаясь в испуге к земле. Говорят, что чудес не бывает, но разве не чудо: 
Громыхали копыта, как камни, летящие с гор, Но, за корни держась, этот кустик полыни как будто Уклонялся от града ударов, как при защите боксер...

И полынь распрямилась и встала из облака пыли,

Как из дыма солдат, победивший в неравном бою

[Хонинов 1981: 191-192].

Р. Ханинова запомнила отцовский завет. Его характер, упорство, непреклонность и сила духа чувствуются в творческом почерке его дочери: «...дерзай, будь стойким до конца, / как куст полыни неприкаян под жестким прессингом коня» [Ханинова 2006: 18].

В другом стихотворении Михаила Хонинова «Будем вместе навсегда» (пер. Н. Кондаковой) образ полыни как символа родины вписан в автобиографическое раскрытие тем Великой Отечественной войны и возвращения из сталинской депортации:

И упал я ниц, раскинув руки,

Не стыдясь, не сдерживая слез,

Обратился к ней в тоске и муке, «И тебе досталось... - произнес

Степь моя, одна в моем наследстве Чистая непуганая синь...»

Верблюжонком ласковым, как в детстве

Целовал я горькую полынь [Хонинов 1981: 68].

В стихотворении «Запах полыни» Р. Ханиновой, написанном по мотивам чеченского предания, образ полыни так же, как и в произведении отца, связан с возвращением в родной край. Ханский сын, загостивший на чужой стороне, в Ичкерии, не обращая внимание на долгие устные и письменные призывы отца, решил остаться там навсегда («...и уже из памяти изжита старая отцовская ладонь» [Поэты Калмыкии: антология 2009: 304]. Лишь «горький» запах полыни, ассоциируемый со «степной» и «полынной» родиной», разбудил разум и чувства героя, - он возвращается домой.

В этом контексте автор удачно использует неологизмы, передающие «волшебные» свойства травы: «пахнет компасно... <тра- 
ва>», «этот запах тем теперь и знатен, что польнит память заодно» [Поэты Калмыкии: антология 2009: 304]. Думается, образ полыни соотносится здесь как с образом родной земли, так и с тем, что являет для автора основу национального миропонимания, - с родным языком. Поэт утверждает, что без языка нет народа, как без родины нет человека. Таким образом Ханинова отражает тождество родного края и национального языка:

И, когда в шатре своем тесемку

Развязал, не ведая, калмык, -

Сразу запах он узнал тот горький, Что единственен, как родной язык.

Запах родины, степной, полынный

Кустиком в ладони восстает,

Сизый цвет крылом своим орлиным,

Манит в вечность - в синий небосвод

[Поэты Калмыкии: антология 2009: 304].

Соотнесение степного растения с образом родного очага, с «пространством родовой, национальной памяти» [Ничипоров 2009: 3] отражается и в стихотворении «Ландшафт истории». «Бытие «полынь-травы» в мире природы вызывает в сознании лирического «я» раздумья о ландшафте культурном, национальном, наполняет эмоциональный фон произведения тревогой за судьбу малых народов перед лицом как исторических катаклизмов, так и мировой энтропии» [Ничипоров 2009: 3].

Но если ветер прихватит

Запах полыни с собой...

Что станет со всеми нами?

Со мной? Теперь и с тобой?... [Ханинова 2009: 3].

Анализ показывает, что флористический образ из творчества поэта-отца переходит в творчество поэта-дочери, сохраняя свою семантику - символа родины, символа несгибаемой воли и силы духа (завет), этноопределяющего признака (полынная память) и, наконец, символа, содержащего в себе потенциал экзистенциаль- 
ных раздумий и обобщений. «Трава полынь, трава степей становится связующим звеном в контакте миров» «в ином - вербальном - измеренье» («Твердят, что я в отца и внешностью и нравом...», 1991) [Дампилова 2010: 73]. Эстетические представления, переходя из калмыцкоязычных произведений М. Хонинова в русскоязычные стихи Р. Ханиновой, остаются неизменны в своем содержании и объединяют творчество двух поэтов.

Глубокий по содержанию поэтический диалог отца и дочери, как мы уже отмечали, обнаруживает много точек соприкосновения в их мировоззрении, нравственных ориентирах. Внутреннее духовное родство выражается в том числе в воспроизведении темы Великой Отечественной войны.

В творчестве М. Хонинова военная тема - одна из главных. Хотя литературный путь М. Хонинова начался еще в 1930-е гг., именно в период войны произошло его становление как поэта. Он писал о том, что было пережито и выстрадано им самим как непосредственным участником Великой Отечественной. Его знали и помнили как Михаила Калмыка на Смоленщине, где он встретил войну в июне 1941 г., и как Мишку Черного в Белоруссии, где он был командиром разведвзвода 646-го стрелкового полка 154-й дивизии. В 1944 г. он был представлен к ордену Боевого Красного Знамени, награжден медалью «Партизан Отечественной войны» I степени. В 2009 г. посмертно получил звание Героя Советского Союза. Стихи М. Хонинова - исповедь воина. Испытав на себе все ужасы страшной бойни, он все же вышел из нее не покалеченным психологически и морально. От его стихов как бы исходит запах крепкой солдатской махорки и порохового едкого дыма (например, цикл «На старой пристани»), они выражают мироощущение, раздумья человека на войне: в бою, в окопе, на отдыхе. Его творчество позволяет увидеть войну глазами человека, прошедшего трудными ее дорогами и убежденного в том, что суровые, жестокие времена учат главному - ни при каких обстоятельствах не утратить человеческого облика. Стихотворения М. Хонинова несут в себе и память о цене победы, память о тех, кто погиб во сла- 
ву Родины, отстаивая ее свободу ценою жизни, о тех, кто, пройдя трудные фронтовые дороги, вернулся с войны и немало сделал в мирной жизни. В «Балладе о гневных тучах» грозовые тучи на небе предупреждают об опасности забвения уроков истории, напоминают современникам о страшной цене Победы, которую за нее заплатил наш народ («Нашей памяти покоя / С той войны все нет и нет...») [Хонинов 1977: 120].

Можно сказать, что в поэзии Р. Ханиновой тема войны также обусловлена биографическим фактором: события Второй мировой, страдания, связанные с ней, радость победы она видит глазами отца. В стихотворении «Я не была на той войне» дочь фронтовика признается:

Война мне снилась памятью отца -

повторным кадром юного лица, -

во мне потом его строкой жива, легендой сохраненная молва [Ханинова 1994: 98].

Уроки памяти звучат в «Балладе о войне», в которой автор поведала историю, рассказанную мужу его дедом. В ней говорится о гибели молодого солдата. Вражеская пуля пробила хлеб, который был у солдата за пазухой, этим же хлебом его помянули однополчане. Образ неизвестного солдата достигает в стихотворении глубокого обобщения как символ всех погибших на войне. И он по-родственному близок всем живым. Смерть воина изображена в балладе как смерть во имя жизни на земле. Лирический подтекст повествования позволяет увидеть мир глазами людей, идущих на смертный бой, выразить предельно острое чувство сопричастности к судьбе поколения, опаленного войной. Помимо мотива исторической памяти поэту удается выразить и мотив межпоколенческой связи: внук - дед, отец - дочь, отражая тем самым сохранение памяти о войне на разных возрастных уровнях, мотив духовной памяти и связи:

Мне в душу врезался снарядом

рассказ военных давних лет, 
как при раскатах канонады

из боя вышли трое... Нет,

один был ранен в грудь. И пуля

вначале хлеб пробила влет:

он был за пазухой.

Волнуясь, друзья окликнули...

Но льет холодный дождь свои потоки

в его открытые глаза.

И изменить ничто нельзя.

Буханка общая, как сроки

уже отмеренной судьбы,

все тяжелей от свежей крови

и горбится, как от беды,

в своем понятии вины [Ханинова 1994: 100-101].

Р. Ханинова говорит о войне сдержанно, она не перегружает излишним пафосом строки своих стихотворений. Одна из главных заповедей поэта, чутко и бережно осваиваемая Ханиновой, - память-наказ отца: беречь самое заветное и дорогое - мир, который защитили наши солдаты. В своих произведениях поэт выражает благодарность не только отцу М. Хонинову, но и всем тем, кто принес желанную победу:

Я в каждом вижу моего отца -

они родня до смертного конца:

Ведь это им, безумно молодым,

развеять удалось военный дым [Ханинова 1994: 99].

Или:

Им ничего от нас не надо,

их завещаньям грош цена.

Для них последняя награда -

что память добрая ценна [Ханинова 1994: 103].

Цикл «Я не была на той войне» раздела «Подкова над отчим домом» - тоже отзвук отцовских стихов о войне. 
Таким образом, в произведениях Р. Ханиновой, связанных с темой войны, лейтмотивом звучит мотив памяти-верности, памяти-преклонения, памяти-долга перед героями - «последняя награда» павшим. В героической судьбе отца «видится искомое тождество слова и дела, жизни и искусства» [Э. Ханинова 2005: 223].

Депортация калмыцкого народа - это еще одна тема, отражаемая Р. Ханиновой в художественном диалоге с отцом. Беда, пережитая калмыками, неизбывная тоска по исторической родине, долгий путь скитаний отражаются в поэтическом цикле «Сибирской памяти тетрадь». Трагедия родного народа стала для Риммы Ханиновой не просто темой разговора с читателями. Это попытка художественно осмыслить свершившееся с точки зрения нерасторжимой связи прошлого и настоящего, сказать свое слово о недопустимости блаженной безответственности перед лицом исстрадавшегося калмыцкого народа. Поэт словно пытается восстановить изъятые «страницы» истории.

В стихотворении «Спецпоселение, спецкомендатура» перед читателем представлено необычно замкнутое, сжатое пространство жизни. Р. Ханинова пишет о несправедливости царящей в те годы системы, когда все калмыки-фронтовики, «вчерашние победители» и защитники Родины, жившие «как в бою» и свято верившие в «торжество вечных истин», были огульно обвинены в предательстве, сняты с фронтов и отправлены в ссылку. В том числе и отец автора - фронтовик, воин-освободитель, орденоносец - был сослан в Сибирь как враг народа. Но он жил под знаком «спец...», «не сдаваясь горю», не теряя ни веры, ни чести:

Спецпоселенье, спекомендатура...

Клеймо предателя - из всех греховный грех -

нес те тринадцать лет из ссылочных прорех

калмык - не друг cmeneŭ, а враг и

спецвредитель,

вчерашний побратим, вчерашний победитель.

Снимали с фронта — в тыл, с передовой -

и в ссылку, в тот неравный бой, 
когда трагедия становится судьбой, а ты с народом, а народ с тобой.

Там мой отец - мир праху твоему -

Не сдался року, горю одному, жил, как в бою, и верил в торжество тех вечных истин, что исторгнуты давно...

[Ханинова 1994: 107].

Можно с полным основанием сказать, что цикл «Сибирской памяти тетрадь» создан на документальной основе. Р. Ханинова родилась за год до окончания ссылки калмыцкого народа. Ее семья, как и все калмыцкие семьи, испытала на себе все тяготы сталинского произвола. В далекой Сибири остались близкие сердцу поэта могилы родных. Противопоставление «родные могилы чужая земля» (хотя автор признается, что Алтай стал ее второй малой родиной) подчеркивает обостренное чувство утраты:

В чужой земле родные мне могилы -

там деда с бабкой в ссылке схоронили:

ей - тридцать восемь лет, ему — за пятьдесят,

не довелось им внуков привечать.

Тепло и свет степного очага

закрыли наглухо сибирские снега [Ханинова 1994: 109].

Произведения Р. Ханиновой насквозь пронизаны болью потерь, в них много грусти, тоски, крика души. Но нет безысходности и безнадежности. Так, в стихотворении «Им снилась степь в раздолье ковыля» в ностальгическую интонацию вплетается жизнеутверждающий мотив. Автор создает притягательный образ степного раздолья, столь важного для самощущения калмыка. Степной простор воспринимался им как аналог свободе, которой калмык был лишен в ссылке. Родная степь грезилась, снилась калмыку в Сибири, но это был не просто сон - тоска по родным краям. Это был зов крови по простору, по воле и свободе. И именно эта сила любви к свободе помогла выстоять народу в час испытаний. 
Им снилась степь в раздолье ковыля

в весеннем мареве родимая земля,

им слышалася жаворонка трель -

природы пробуждения свирель... [Ханинова 1994: 108].

Помогало и стремление к сохранению вечных ценностей, под которыми подразумевается сокровенная любовь и привязанность людей к родному краю, сбережение традиций и обычаев, заветов предков:

И свадеб скромных простота,

и похорон суровых бденье,

и разговоры до утра,

и песни в хоре осторожном,

и сказок мудрых острота, -

забыть все это невозможно [Ханинова 1994: 111].

В стихотворении «Обычай предков ....» Ханинова вступает в диалог с А. Солженицыным, написавшем в романе «Архипелаг Гулаг» о том, что «калмыки не стояли - вымирали тоскливо...», правда с оговоркой, что он их не наблюдал. В своем произведении, представляющем собой целостную по своей форме ораторию мужеству и стойкости калмыцкого народа, автор оспаривает мысль писателя, полемизирует с ним, раскрывая при этом национальный характер, этнопсихологические особенности калмыцкого народа. Терпение - «сдержанность всех чувств» - самое трудное качество, воспитывающее человека, раскрывается в произведении как результат героического противостояния. Люди не сломались, они словно копили в себе внутренние силы. Эта мысль проходит лейтмотивом через все произведение. Как справедливо отмечает В. Очир-Гаряев, после поэтических строк Р. Ханиновой уже поиному воспринимаются слова А. Солженицына, в них уже нет безысходности и холодного отчаяния: «Можно только поблагодарить поэта за столь глубокое проникновение в сущность национального характера степного народа» [Очир-Гаряев 1998: 119]: 
Обычай предков - сдержанность всех чувств лишь иноверцев может обмануть.

Крик боли, горя не сорвется с уст, без слез проводит всех в последний путь, он примет смерть с достоинством, как жил... Позор мужчине - слабость показать, и стыд мужчине без толку болтать... $<\ldots>$

Степняк не плачет - лишь сожмет глаза:

в прищуре даль дистанции ясна, ни радости, ни горести слеза на людях не проявится сама. О, мужество калмыка - на скаку взлететь в седло земного бытия, и через силу, через «не могу»так удержать горячего коня, чтоб только знал один степной курган, как мало стрел хранит его колчан, как жизни сей сужается аркан, как возвращается к тебе он, Эрлик-хан...

[Хонинов, Ханинова 2010: 161-162].

Как показывает анализ, тема сибирской ссылки находит самобытное художественное выражение в творчестве Р. Ханиновой. Обращение поэта к ранее запретной теме - это не просто дань памяти прошлому народа, но и исповедь поколения, родившегося и выросшего в Сибири, осознание всей глубины и масштаба тяжкого испытания в судьбе своего народа. Его нравственные уроки в контексте исторической и культурной памяти отразились на развитии поэта. Трагедия народа дала толчок к осмыслению человека и времени, человека во времени.

Актуальность творчества Риммы Ханиновой проявляется в том, что она создает поистине национальную поэзию, в которой с особой силой проявляется интерес к истории народа, его культуре и этнографии. Творческое проникновение в недра национального 
миропонимания проявляется в глубинной связи с устным народным творчеством. Фольклорное влияние в ее поэзии в определенной степени преемственно, в нем сказалось следование творческим принципам отца. Как признавался сам М. Хонинов, главным учителем для него был эпос «Джангар» и богатейший калмыцкий фольклор. При этом поэт ценил богатство фольклора любого народа: «Народное творчество, чье бы оно не было - русских, казахов, белорусов, - очень люблю. < ..> Считаю, что без национального колорита, без национального орнамента нет настоящей литературы» [Хонинов 2003: с. 16].

Обращение к фольклорному материалу - одна из важнейших черт творчества Р. Ханиновой. Она активно и открыто использует сюжетные мотивы легенд, сказок, преданий разных народов. Калмыцкие пословицы и поговорки буквально пронизывают ткань ее стихотворений. Их органичное сочетание с вполне современным языком и стилистикой автора свидетельствует о большом потенциале возможностей творческого освоения фольклорных традиций в современной калмыцкой литературе.

В фольклорном направлении поэзии Ханиновой также проявляется ее тенденция к диалогу. Ее собеседник в данном случае народ, коллективный творец богатейшего пласта художественной словесности. Поэт как будто обращается за советом к глубоким смыслам и ярким образам устного творчества и в ответ разворачивает собственное умозаключение, свое осмысление сюжета и образный ряд.

Творчески осваивая идейно-художественную структуру разных жанров устной поэзии, синтензируя, используя разнообразные ассоциативные связи, Ханинова создает качественно новые поэтические произведения.

Р. Ханинова особенно часто использует афористический фольклор в своих поэмах, тем самым способствуя углублению их философского содержания, а также предоставляя возможность оценить своеобразие и совершенство этого вида устного народного творчества. 
Сюжеты и образы пословиц вплетаются автором в художественную ткань произведения и составляют один из значимых этностилевых пластов ее поэзии.

Как правило, создавая поэтическую интерпретацию народного афоризма, Ханинова в примечаниях приводит его изначальный фольклорный вариант: «Слепой корове не показывай воды», «Слово, сказанное без соображения, подобно выстрелу без цели» и т. д. По словам академика Г. Н. Волкова, «развернутые примечания это еще одна книга в книге» [Волков 2005: 15].

Как верно отмечает К.А. Джушхинова, обилие, буквально «нанизывание» пословиц и поговорок на нить авторского повествования - это «не просто художественный прием градации (от частного к общему), не просто сюжетообразующий фактор, но в то же время, возможно, показатель специфики речевого поведения калмыков, склонных к краткости, немногословию. Все эти качества на протяжении многих веков воспитывал буддизм, проповедавший терпимость, сдержанность во всем» [Джушхинова 2003: 46].

Р. Ханинова обращается и к жанру загадок, тематика которых в основном отражает явления природы:

Расстелила ночь на небе свой ковер -

не ступить, не полежать, он непростой: ${ }^{1}$

Мастерица-ночь весь золотом ткала,

На ковре луна как с чаем пиала.

[Хонинов, Ханинова, 2002: 108].

С фольклорной темой тесно и органично смыкается детская тема в творчестве Риммы Ханиновой. Так, по мотивам сказок народов мира (индийская, иракская, латышская, аварская и т.д.) написан цикл сказок для детей, включающий в себя шестнадцать стихотворений. Он имеет подзаголовок «для детей изрядного возраста», отсылающий к сказкам М. Е. Салтыкова-Щедрина. Автор в предисловии к публикации выражает надежду, «что читатели найдут что-то свое в фольклоре, возвратятся в счастливую страну детства, прочитают вместе с детьми и внуками (семейное чтение),

${ }^{1}$ Калмыцкая загадка: «Ковер, а не ступишь на него ногой» (Звездное небо). 
заново открывая удивительный мир народного юмора, сатиры и мудрости» [Ханинова 2002: 12]. В цикл стихотворений по мотивам сказок народов мира «Умная мышка» входят двенадцать произведений, опубликованных в детском журнале «Байр» (Элиста, 2002, № 5).

Как отмечает С. В. Шаводаева, «география сказочных сюжетов (индийская, иракская, цыганская, африканская, польская, кубинская, русская, латышская, аварская, калмыцкая и др.), тематика, система образов, стиль, с одной стороны, подтверждают культурный универсум, с другой - определяют своеобразие национального уникума». Так, в извечном мировом сюжете противоборства мышки с котом при переменном характере исхода чаще победа достается более умному зверьку — мыши» [Шаводаева 2004: 122]. В сюжете Р. Ханиновой, созданном по мотивам иракской сказки, мышка благодаря своей смекалки, догадливости и находчивости также одерживает верх над не менее хитрой злодейкой-кошкой.

В сказке «Находка», созданной по мотивам таджикской сказки, рассказывается о крестьянине, который, идя однажды по полю, нашел ослиную подкову и очень обрадовался своей находке, думая, что ему наконец-то не придется ходить пешком. Он сразу же стал думать о том, что хорошо было бы найти еще три подковы и одного осла.

\section{Вот счастье!}

Теперь мне больше не ходить пешком.

Еще бы три подковы в одночасье

да одного осла найти бы мне потом [Ханинова 2002: 13].

Смысл данного произведения перекликается с поговоркой «делить шкуру неубитого медведя», пришедшей в русский язык из басни французского поэта Ж. Лафонтена «Медведь и два охотника»:

Сказки Р. Ханиновой радуют читателей новизной и законченностью созданных картин, разнообразием стихотворных ритмов, неожиданностью поворотов темы, крепостью и богатством поэтической речи, полной движения и жизни. Для них характерны 
глубокое содержание, художественность изложения, веселая динамика, являющаяся, безусловно, самоцелью поэта, выраженная педагогическая направленность (неизменное присутствие поучения, морали), четкая композиция, облегчающая восприятие.

В отдельных сказках педагогическая задача не является ярко выраженной. Так, к примеру, в литовской сказке «Волк и баран» мораль - в добродушной насмешке над легкомыслием и глупостью в образе волка, которого ловко перехитрил находчивый баран, пообещавший с разбегу запрыгнуть волку прямо в пасть:

А волк пришел в себя, помял бока:

Я съел барана? Или нет пока?

Должно быть, съел. Совсем нет сил,

Так разбегаться кто его просил?.. [Ханинова 2002: 12].

Благодаря ярким образам и увлекательному сюжету дидактичность ничуть не снижает художественности сказок Р. Ханиновой. Их назидательная эффективность заключается в том, что поучительный вывод совершенно самостоятельно складывается в сознании читателя (например, сказка «Шакал и черепаха»).

В ряде сказок поэт указывает детям на объективные условия жизни, а чаще всего - на естественные последствия дурных поступков, уверяет и убеждает в важности хорошего поведения. Так, в «Ссоре птиц» рассказывается о том, как птицы попали в лесную сеть птицелова. Стали думать, как выбраться на волю. Договорились дружно взмахивать крыльями, чтобы сетка поднялась, но, уже поднявшись в небо, начали вдруг спорить и разбираться, кто больше всех старается, а кто притворяется, «не пачкаясь во прахе» [Ханинова 2002: 10]. В начавшейся перебранке птицы и не заметили, как сеть сама собой стала опускаться на землю.

Понимание природы и целей ссор в данном случае призывает к уступчивости, уживчивости, умению договариваться и действовать сообща, а также думать не только о себе, но и о других. Ссоры никогда не приводят к добру: если бы птицы не начали раздор и не начали спорить, сеть не опустилась бы на землю, и они улетели. 
Таким образом, в своих сказках Римма Ханинова формирует программу элементарных нравственных реакций (выборов) маленького читателя, то есть того, что можно назвать нравственным, этическим отношением к действительности. Эта программа создает как бы первичную сетку образов-представлений и мысленных «выборов» читателя, которая в дальнейшем может сколь угодно много и долго усложняться и конкретизироваться. Таким образом, за маленьким сказочным миром Ханиновой, как правило, стоит большой реальный мир. Как верно отметила С. В. Шаводаева, «детская поэзия Р. Ханиновой в своем культурном универсуме подтверждает унификацию читательской адресации, равно обращенной как к взрослой, так и к детской аудитории, в традициях калмыцкой литературы» [Шаводаева 2004: 123].

Осмысление разных форм художественного сознания народов мира отразилось и в поэтическом цикле «Древние метаморфозы», который, как признается сам автор, явился для нее «стремлением осмыслить мифы и легенды народов мира в аспекте идейно-художественной преемственности, в преломлении сознания нашего современника, в метафизической взаимосвязи мира, человека и природы» [Ханинова 2005: 149]. Как отмечается, цикл «вместил в себя не только и не столько восточную притчевую традицию, но и отразил тяготение к притчевости современного художественного сознания» [Асмолова 2005: 15].

Кроме того, в цикле «Древние метаморфозы», довольно разнообразном по содержанию, отчетливо проявился культурный универсализм поэта, позиционирующего себя «на стыке античного и евроазиатского миров» (А. А. Бурыкин). Р. Ханинова обращается к мифологии китайской («Шелковое покрывало»), древнегреческой («Дни Алкиона», «Цветок солнца»), скандинавской («Прут омелы»), германской («Сторож у дороги»), калмыцкой («Лотос»), арабской («Сердце оливы»). Таинственные метаморфозы, заполнившие художественное сознание поэта, по мнению И. Ничипорова, «явились оригинальным творческим актом поэтического преображения древней мифологии, которое высветило глубокую 
философичность Риммы Ханиновой-лирика, широчайшие культурфилософские горизонты ее художественной мысли» [Ничипоров 2004: 4].

Еще одно яркое доказательство органической близости поэзии Р. Ханиновой к фольклору — цикл «Ключи разума», для которого характерно творческое осмысление традиций монгольской дидактической поэзии.

Надо отметить, что стремление к художественной циклизации стихотворений, объединенных на основе идейно-тематической общности, - одна из характерных особенностей творчества Риммы Ханиновой. Циклизация помогает поэту углубить смысловые акценты темы, полнее и ярче раскрыть образно-философский мир своей поэзии, раскрыть собственную художническую позицию.

Источником вдохновения при написании цикла «Ключи разума» послужил памятник древней монгольской литературы, самый известный и популярный сургал «Оюн түлкүр» («Ключ разума») Как известно, существуют два варианта данного сочинения. Монгольская версия, как отмечают исследователи, была впервые зафиксирована в первой половине XIII в. Калмыцкие же (ойратские) списки появились лишь в первой половине XVII в. после создания алфавита «тодо бичиг». XVII век - особый период в истории монгольских народов, в особенности ойрат-калмыцкого. Именно в это время ойраты обрели свою национальную письменность, начинает складываться ойратская литература, соответственно осваиваются собственно литературные жанры, к которым относятся и сургалы.

А. В. Бадмаев считает, что «калмыцкий текст “Оюн түлкүр" полностью соответствует монгольской версии, изданной Ц. Дамдинсурэном, небольшие различия носят вариативный характер» [Бадмаев 2003: 224]. Исследуя идейную направленность поучений, исследователь также замечает, что многие изречения памятника «созвучны народным пословицам и поговоркам, содержат наставления самого общего характера, касающиеся повседневной жизни и быта, критикуют многообразные пороки и недостатки, вообще свойственные человеку и бытующие в обществе (ложь, клевета, 
зависть, хвастовство, жадность, скупость, жестокость, ненависть, воровство, убийство и т. п.)» [Бадмаев 2003: 224]. «Уже в первых строках текста составитель (составители) «Ключа разума» призывает читателя к тому, чтобы они не забывали («вспоминали») строки небольшой шастры, в древности составленной предками» [Бадмаев 2003: 223].

В авторском предисловии к циклу Р. Ханинова отмечает, что она попыталась «приблизить древнюю назидательность предков к современному читателю», а через это — «пробудить интерес к вечным ценностям человеческого бытия» [Ханинова 2005: 197]. Созданные по мотивам афоризмы представляют собой отнюдь не переводы монгольских миниатюр дидактического звучания. Автор не идет по линии простого переложения первоисточника. Осмысление произведения устной поэзии поэт, как всегда, строит в диалогическом ключе и определяет как «выборочное чтение с элементами соразмышления и сопереживания» [Бадмаев 2003: 197]. Обращение к памятнику древней монгольской литературы стало для автора не только закономерным плодом давнего творческого интереса, но и, безусловно, обращением к культурным истокам, осмыслением своих корней, заветов и традиций предков.

Цикл «Ключи разума» состоит из двадцати семи стихотворений, каждое из которых носит самостоятельный характер и отличается от других художественными и тематическими особенностями. Если афоризмы и изречения первоисточника «преподносятся без видимой связи и системы», и «иногда даже соседствующие стихотворные строки никак между собой не связываются» [Бадмаев 2003: 224], то поэтический цикл Ханиновой несколько отличается в этом плане. Идейная направленность поучительных изречений автора как бы выходит за рамки одного стихотворения, связываясь с предыдущим на уровне определенной подтемы. Неслучайно некоторые из произведений Р. Ханинова отмечает строчными буквами: IIIa, IIIб и т. п. Различны ханиновские сургалы и по объему. Стихотворные формы, характеризующиеся глубиной и тонкостью философской мысли, носят характер двустиший и четверостиший. 
Одним из факторов художественной целостности произведения является семантика метафорического образа «ключей», ассоциирующегося с присущим только человеку даром мысли, его устремленностью к познанию тайн бытия, к подлинно народной, выразительно национальной мудрости предков. Важно заметить, что по сравнению с первоисточником слово «ключ» поэт употребляет во множественном числе, «подчеркивая свое желание не декларировать общеизвестные истины, а художественно высветить многосложные пути, избираемые для их разумения, принципиальную несходимость человеческих индивидуальностей в этом процессе» [Ничипоров 2005: 130]:

Ключи к поучению - мудрости предков -

Откроют замки добродетели в мире.

Увы, но ленивому телом нередко

И связка ключей как пудовые гири.

Ленивое тело и к мысли лениво:

Лелея покой свой (движенье - угроза!),

Ленивец способен лишь молвить спесиво

И не меняя удобную позу [Ханинова, Ничипоров 2005: 198].

Исходя из понимания того, что в реальном мире неизбежно присутствует много зла, автор предлагает свой вариант противостояния ему. По-житейски мудро поэт наставляет, что необходимо делать, чтобы не отравлять свою душу негативными эмоциями, а воспитать в себе положительные качества, избегать неблагих поступков, сохранить светлое, милосердное отношение к окружающей жизни и к людям:

Не глядя в сторону, усердствуй -

Жизнь не длинна.

Не помня зла, помилосердствуй -

Ведь суть одна [Ханинова, Ничипоров 2005: 211].

Немаловажным циклообразующим фактором являются философские рассуждения-обобщения о сути человеческого бытия. Так, развивая тему преодоления жизненных трудностей и испы- 
таний, автор утверждает, что слепому, неумолимому року человек может противопоставить лишь выдержку, несокрушимую твердость духа и готовность все претерпеть:

Будучи жестким и грубым, - не устрашишь.

Спокойствием, твердостью духа лишь устрашишь

[Ханинова, Ничипоров 2005: 199].

Напряженно размышляя о путях постижения бытия и способах существования в нем, поэт развивает мысль о мудреце и глупце, сопоставляя их действия в многосложных жизненных «поединках»:

Гордец, умом другим когда он превзойден,

Стыдится, в поединок не вступая, -

Стыдится потому, что (мнит он) посрамлен.

Застенчивость у мудрого иная

[Ханинова, Ничипоров 2005: 215].

Существенное место в сургалах Ханиновой занимают сложные гносеологические рассуждения об индивидуальном познании человеком парадоксов и тайн окружающего мира, приобретаемом ценой ошибок и нелегкого опыта. Автор придает этим рассуждениям этическую направленность, напоминая о нравственной составляющей процесса познания:

Не помышляя о зле, напрасно все отвергаешь.

Так ошибиться вполне можешь, не понимая.

Заранее всем говоря, что обо всем знашь,

Ты возвращаешься, вслед на пятки всем наступая

[Ханинова, Ничипоров 2005: 202].

Подлинная мудрость поведения в жизни, полной заблуждений и соблазнов, состоит, по мысли автора, именно в преодолении безнравственности, в «широте личностных устремлений, не замыкаемых индивидом на самом себе» [Ханинова 2005: 224]:

Если сказав «Я знаю», знаешь себя самого,

Мудрость твоя на свете и стоит-то ничего

[Ханинова, Ничипоров 2005: 204]. 
Лейтмотивными в сургалах-поучениях Ханиновой становятся и размышления о могущественной силе слова, требующего внимательного, максимально ответственного обращения с ним:

Прежде чем слово сказал,

Дважды его проверил,

Понял теперь, что сказал, -

Мысль другим доверил [Ханинова, Ничипоров 2005: 201].

В следующем стихотворении Ханинова выражает свое представление о святости слова, сопряженного с мудростью. Мудрость эта скрывается не в «лаве» многословия, а, скорее, в неизреченности, в умении говорить в меру, ибо, по мнению поэта, настоящая мудрость немногословна:

Много слов произносишь, думаешь - слава.

Но на поверхность по сути вытекла лава

[Ханинова, Ничипоров 2005: 200].

Бессмысленность сказанной речи поэт окрашивает яркой и оригинальной метафоричностью:

Глупец, даже взрослый, десятками слов

Не успокоит мышей в норе вновь

[Ханинова, Ничипоров 2005: 213].

Стиль сургалов Ханиновой характеризуется емкостью словесной фактуры в соединении с образными параллелизмами и сравнениями, что делает их содержание более доступным:

Душа у зависти как сажа на котле:

Чем больше ешь - не чище на столе

[Ханинова, Ничипоров 2005: 218].

Все сургалы Ханиновой - это концепция поведения, проповедь гуманистических устоев морали. Как справедливо отмечает И. Ничипоров, созданный в русле древней восточной поэтической традиции цикл с представленными в нем философско-нравственными сентенциями «несомненно дал этой традиции «второе дыхание» в современном культурном контексте» [Ничипоров 2005: 225]. Автор отразила саму суть дидактической поэзии, высветила 
сокровенные глубины народной мудрости, представленной в метафорическом образе ключей, словно возрождая их на новом современном уровне, сближая тем самым духовность прошлого и настоящего.

Глубокое знание фольклора и многократное обращение к нему сыграли решающую роль в становлении Р. Ханиновой как поэта. Для нее фольклор - не объект для подражания, а путь выражения собственной индивидуальности. Интерес к калмыцкому устному народному творчеству во многом предопределил ее обращение к крупным поэтическим формам. В этом поэт как бы продолжает диалог с отцом, следуя его творческим принципам. Лирико-философские поэмы «Час речи», «Все движет Женщина-Любовь», «Солнечный Лев», объединенные темой историко-культурной преемственности, поэт создает практически сразу после того, как перевела в 1998-1999 гг. две большие поэмы М. Хонинова, написанные по фольклорным сюжетам: «Сказание о калмычке» и «Почему у Совы нет ноздрей».

«Виртуальный диалог» двух поэтов, отца и дочери, — это диалог поколений в «вербальном измеренье», во времени и пространстве. Как справедливо заметил Н. Ц. Манджиев, поэт М. Хонинов выступает как посредник в передаче народного опыта и культуры и как аккумулятор идей, источник вдохновения для поэта Р. Ханиновой в ее нелегких поисках художественной истины. В то же время поэтическое воплощение этого диалога - двойная ответственность для Р. Ханиновой, стремление еще раз раскрыть и показать талант отца, исполнение его заветов и, разумеется, дань памяти.

\section{2. Идеи ценности синтеза, или взаимодействие традиций Востока и Запада в поэзии Р. Ханиновой}

Обращение к культурному и философскому наследию многих народов является сущностной стороной поэтического творчества Риммы Ханиновой. В этом она видит один из путей реализации диалога культур в литературном пространстве, возможность ши- 
роких мифопоэтических ассоциаций и обобщений. Особенный и постоянный интерес вызывают у поэта богатство и многообразие культур, религий, философских учений народов Востока. Как отмечает Р. Ханинова, ей как восточному человеку, получившему европейское образование, интересно вернуться к своим культурным истокам.

Восточный вектор творческого поиска Р. Ханиновой плодотворно воплотился в ряде произведений, в числе которых поэтический цикл «В тени Конфуция» (2002). Творчески вчитываясь в наставления Конфуция, Р. Ханинова разворачивает диалог с древним мыслителем на тему принципов морали.

Значимость и специфика всего цикла отражается в стремлении отразить глубину ассоциаций и смысловых связей, сочетающих в себе, с одной стороны, конфуцианские идеи, а с другой - мироощущение современного человека, его новый взгляд на традиционные темы древней китайской дидактики.

«Конфуцианский» цикл Р. Ханиновой состоит из тридцати пяти стихотворений, различающихся, во-первых, жанровой принадлежностью (диалоги, притчи, краткие изречения афористического характера), а во-вторых, - объемом (двустишия, четверостишия, восьмистишия и т. д.). Во всех произведениях проповедуются положительные знания, гуманистическая мораль, нравственная ответственность.

Суть художественной циклизации состоит не в плавном перетекании смысла из одного стихотворения в другое, а в построении смысловых связей на границах одного произведения с другим. В результате образуются своеобразные поэтические подциклы, создающие сложное смысловое единство: автор будто бы развивает диалог с великим китайским мыслителем. Созданные в «тени» многовековой восточной мудрости стихотворения-миниатюры отличаются глубиной и тонкостью мысли, широтой обобщения и афористичной остротой.

В авторском предисловии поэт обращает внимание на ключевой в цикле образ тени, обозначенный в его названии: «Словом 
«тень» в Китае обозначалась живая личностная преемственность поколений: потомки живут в «тени» своих предков... Недаром в древности говорили, что у каждой вещи есть своя тень: даже когда исчезнет сама вещь, останется ее тень... Бессмертие мысли подкрепляется бессмертием личного рода...» [Ханинова, Ничипоров 2005: 97].

Таким образом, поэт в поиске истины обращается к философским раздумьям о ценностях земного и посмертного бытия. Так, сила человечества, по мысли Ханиновой, состоит в могуществе силы мысли, превозмогающей смерть и спасающей человека от забвения и беспамятства. Надо заметить, что мысль поэта о «перспективе человеческой судьбы, завершаемой смертью» (Ничипоров И.Б.), является лейтмотивом практически всех произведений Р. Ханиновой. Неслучайно, например, в поэме «Час речи» в качестве одного из эпиграфов (а в поэме их два) автор использует строки из стихотворения И. Бродского: «...От всего человека вам остается часть речи. Часть речи вообе. Часть речи» [Хонинов, Ханинова 2002: 24]. В этом смысле величие человеческой мысли, ее непреходящая, вечная ценность является для автора той константой, благодаря которой возможен и строится диалог с великим наставником. Отсюда еще одна центральная тема цикла - «связь личности с наследием древности» [Ничипоров 2005: 124]:

Хранящий древности тепло,

Ты не своди его к забаве,

Вноси открытие свое -

Тогда учить ты будешь вправе

[Ханинова, Ничипоров 2005: 123].

Познание и понимание прошлого, по мысли Конфуция и поэта, ведут к созиданию будущего. Размышление об обязательном стремлении каждого человека впитать и постичь великие заветы предков, не теряя тем самым связь с «корнями», содержится в стихотворении-притче «Тень и след» (2002). В произведении говорится об участи человека, попытавшегося убежать от собственной тени, чем он и обрек себя на смерть. Таким образом, глу- 
боко философская мысль о ценности и необходимости связи с прошлым выступает как бы «противовесом беспамятству и «робинзонаде» [Ничипоров 2005: 123], являясь при этом основой всего цикла.

Начальное стихотворение «конфуцианского» цикла представляет собой своеобразную вводную формулу, подготавливающую читателя к погружению в мир восточной философии. На ценностно-идеологическую установку произведений указывает и вопросительная модальность стиха, сообщающая заряд философских раздумий об искомом смысле земного бытия, о «пути творца», вступившего на путь познания истины:

Что ищем мы в заветах мудреца?

Безмолвия в речах ?

Иль путь в молчании? Ведь путь творца

Не выразить в словах?

[Ханинова, Ничипоров 2005: 98].

Осмысляя основополагающие принципы китайской философии, Ханинова отражает в этих строчках восточное понимание мудрости, молчание, немногословие, умение говорить в меру. «Мудрее тот, кто прячет свою мудрость», - соглашается с Конфуцием поэт. Раздумье о неизреченности и сдержанности в речах позволяет автору прийти к формулировке такой черты, присущей многим восточным народам, как сознательное контролирование речи, ответственное обращение со словом:

Мудрее тот на свете, говорят, Кто прячет мудрость ото всех умело, Кто скажет ровно столько и впопад,

Чтоб выразить свой смысл смело.

В осмысленной же речи, что сказал,

Уравновешена неизреченность.

Внимающий, что истины алкал,

Понять стремится предопределенность

[Ханинова, Ничипоров 2005: 99]. 
Размышления о необходимости вдумчивого обращения со словом содержатся и в стихотворении «На белой яшме пятнышко стереть...» $(35)^{1}$ :

На белой яшме пятнышко стереть

Возможно, испытав усталость.

А на словах своих пятно стереть

Нигде и никому не удавалось

[Ханинова, Ничипоров 2005: 134].

Рисуя конфуцианский образ истинного мудреца, Р. Ханинова сквозь призму метафор подчеркивает его отношение к мирским ценностям: безразличие к еде, богатству, жизненным удобствам и материальной выгоде. Он посвящает свою жизнь служению высоким духовным идеалам, людям и поиску истины:

Для мудреца богатства и чины,

Что облака на небе, мимолетны.

Его потребности естественно скромны:

Вода, простая пища и охотно

Он локоть голове спать подставляет,

Четыре стороны не понаслышке знает

[Ханинова, Ничипоров 2005: 104].

Неслучайно, что в стихотворении «Подобно сердце мудрого горе» $\{3\}$ сердце человека, вступившего на путь истины и сумевшего отречься от всего временного, ассоциируется автором с «горой», символизирующей достижение высокой ступени самосовершенствования, идею духовного возвышения и абсолюта:

Подобно сердце мудрого горе.

Горе, чья твердь научит дух

Гранитной тверди в языке.

Уловит только чуткий слух,

Какой покой хранит в себе

Забытых бурь подземный рокот,

1 Здесь и далее в фигурных скобках \{\} указывается порядковый номер стихотворения в цикле. 


\section{Как неизбывные в судьбе}

Сомнения и редкий ропот

[Ханинова, Ничипоров 2005: 100].

Процесс поиска «утонченной» истины, открывающейся не каждому, является одним из лейтмотивов цикла. Ее невозможно постичь ни зрением, ни слухом, ни осязанием. Однако, встав на путь познания истины, человек обнаруживает глубинные закономерности и тайны бытия, делает свой путь великим, обретая тем самым гармонию. Формально-содержательное начало произведения подчиняется следующему принципу: две первые строки содержат тезис, а две последующие - поэтически оформленный пример:

Путь расширяет человек - и не иначе, -

Идет за истиной, ее определяет.

Так птица дерево себе вновь обозначит.

А дерево же птиц не выбирает

[Ханинова, Ничипоров 2005: 102].

Посвятив всю жизнь обдумыванию священного вопроса, «как жить мудро и достойно», Конфуций в свое время пришел к выводу, что определять поведение человека при любых обстоятельствах (в обществе, в семье и т.д.) должны высокие нормы морали, и этот вывод преподносится как непреложная истина. Все люди по своей природе похожи друг на друга, но в то же время им присущи разные привычки, поэтому не все способны быть одинаково высоконравственными. Одни становятся на путь добра, другие - на путь зла:

Людей природа лишь объединяет, Привычки же людей разъединяют

[Ханинова, Ничипоров 2005: 105].

Поэт, развивая мысль Конфуция, говорит о необходимости самосовершенствования личности. Она тонко и ненавязчиво подводит читателей к тому, что каждый способен сделать свой путь великим. Для этого человеку просто необходимо, не останавлива- 
ясь, «шагами мелкими» идти вперед, и тогда истина познается им без каких-либо усилий:

Не пренебречь делами буден -

Тогда успешными всегда мы будем.

Ведь даже самый длинный путь

Шагами мелкими идем, ты не забудь

[Ханинова, Ничипоров 2005: 110].

Самосовершенствуясь, человек должен соблюдать «идеальные» правила или нормы поведения, стремиться к исправлению недостатков, к признанию неправильных поступков и совершаемых ошибок. По Конфуцию, по-настоящему ошибается тот, кто, спотыкаясь, не исправляет их:

Все спотыкаются в ходьбе:

Ребенок и старик.

Но хром, пожалуй, тот в уме,

Кто исправляться не привык

[Ханинова, Ничипоров 2005: 107].

Общеизвестно, что одно из ключевых в учении Конфуция понятие гуманности, которая в его понимании неразрывно связана с чувством долга. Основой же человеколюбия мыслитель считает высшую почтительность детей к родителям и уважение к старшим. Следуя конфуцианским моральным предписаниям, Р. Ханинова также указывает читателю на то, что сила человечества заключается в родовой памяти:

В семье истоки истины всегда.

Так корни - крона тем сильны,

Что почвой всей укреплены.

И мысли Куна' ${ }^{1}$ продлены

В прямых потомках всей родни

[Ханинова, Ничипоров 2005: 112].

${ }^{1}$ Настоящее имя Конфуция - Кун Цю (Кун - фамилия, Цю - имя). Привычное нам слово Конфуций происходит от латинской транскрипции китайского словосочетания Кун фуцзы, в дословном переводе означающее «учитель Кун» . 
В стихотворении «Учитель Кун с учениками» $\{23\}$ поэт, описывая возвращение странствующего человека, утратившего родовые корни, вновь предупреждает о недопустимости забвения семейных отношений, пренебрежения их святостью. По мысли автора, они являют собой суть жизни:

О, не судите меня строго!

Теперь я только осознал:

Желает дерево покоя,

А ветер-непоседа юн.

Желает сын заботиться о доме,

А в лютне не хватает струн...

- О, как же поучительна судьба, -

Сказал Учитель, - ныне и всегда

[Ханинова, Ничипоров 2005: 121-122].

В подобных притчевых произведениях цикла, представляющих собой отрывки бесед великого Учителя с учениками и имеющих преимущественно диалоговую конструкцию, автором тонко раскрывается сердцевина конфуцианского учения, сущность глубокой философской мысли наставника, его значительный духовный опыт. При этом отражаются не просто общие вопросы бытия, а этико-философские размышления о жизни и смерти, старости, зрелости и юности, о том, что окружает человека, находится в центре его созерцания и мысли.

Так, в стихотворении «Спросил Учителя однажды ученик» $\{33\}$ поэт затрагивает один из величайших парадоксов действительности и вечную загадку совместимости жизни со смертью. Смерть - естественное явление, общий удел всех. Движение к ней неумолимо, и это движение никогда не прекращается. Однако, согласно мысли поэта, к смерти надо относиться с философским спокойствием и безразличием, как к естественному, закономерному явлению. У человека же, не познавшего жизнь, не должны возникать мысли о смерти; он должен жить, стремясь к максимальному использованию радостей жизни. Как справедливо отмечает 
И. Б. Ничипоров, слово автора служит здесь «своеобразным лирическим комментарием к изречению главного героя, попыткой его личностного прочтения» [Ничипоров 2005: 128]:

Еще не знаешь ты о жизни ничего.

Так разве можешь, забегая, знать -

Беспечно, праздно и легко, -

Что значит смерть и тайну постигать?

[Ханинова, Ничипоров 2005: 132].

Немало внимания в цикле уделяется и идее ценности просвещения. Человеческую жизнь поэт рассматривает как постоянный процесс учения, воспитания, осмысления накопленных знаний и опыта. При этом напоминает, что любая цель достижима при должном старании, выдержке и терпении:

В учении излишня торопливость.

В учении потребна терпеливость.

Так, если лук все согнутым держать,

Упругость потеряет, чтоб стрелять

[Ханинова, Ничипоров 2005: 115].

В притче «Звуки музыки лишь посвященным...» рассказывается о постепенном постижении юным Куном основ музыкального искусства. Здесь Р. Ханинова снова ратует за важность усердного обучения наукам, указывая при этом на бесконечность и перспективность этого процесса. В подробном описании непрестанных многотрудных усилий старательного ученика, его стремления понять не только само музыкальное произведение, но и личность художника, его сотворившего, автором отражаются способность человека постигнуть суть вещей путем углубления в аспект познания:

Нет, учитель. Прошу вас немного

Дать мне времени, - молит вновь Кун.

- Не судите меня очень строго:

Без седла еще мысли скакун.

Мне понять захотелось, учитель, 
Кто был песни такой сочинитель.

Вновь над лютней склонился, являя

То волненье, то думу скрывая

[Ханинова, Ничипоров 2005: 116].

$\mathrm{B}$ целом цикл Риммы Ханиновой «В тени Конфуция» помогает не только вникнуть в гуманистическое учение восточного мыслителя, в основе которого лежат общечеловеческие принципы, но и, как отмечает И. Ничипоров, способствует «творческому самопознанию» самого автора, его постижению вековечных тайн бытия [Ничипоров 2005: 132]. Поэт словно вбирает в себя опыт древней мудрости, пронизывает его собственной оценочностью, делая при этом глубокие нравственно-философские заключения. Особая значимость всего цикла заключается и в том, что поэт как бы погружает читателя «в тень» великой мудрости, будит его мысль, задает ей определенное направление, сопрягая тем самым мышление современников с бесценными сакральными идеями древнейшей китайской дидактики.

Интерес к культурному наследию Востока предопределил и написание Р. Ханиновой лирико-философской поэмы «Формула судьбы» (2001), написанной по мотивам персидской сказки «Игра в шахматы». В ней, как отмечают исследователи, обозначилось то, что характерно для всех «восточных» произведений поэта, культурный универсализм: поэт обращается не к конкретным реалиям той или иной страны или эпохи, а к знаковым, культовым явлениям духовной культуры, к тому, что дал Восток всему миру. $\mathrm{C}$ «Формулы судьбы» в творчество Ханиновой входит исламская тема. Содержание произведения насыщено многочисленными реминисценциями: суры Корана, стихи Виктора Гюго, Джорджа Гордона Байрона, арабские пословицы (например, «Мир — в тени мечей, и даже рай под их сенью») и многое другое.

«Формула судьбы» — образец жанра лирико-философской поэмы. «Тщательно прописанный «местный» колорит, передавая ауру далекой эпохи Древнего Востока, сопряжен в художественной логике произведения с постановкой экзистенциальных проблем, ко- 
торые обращены к извечным закономерностям бытия личности в историческом пространстве» [Ничипоров 2005: 187]. Философская идея произведения - мысль о метаморфозах, парадоксах и драматизме человеческого бытия - раскрывается поэтом через напряженный конфликт: в ходе вынужденной междоусобной войны за трон между двумя наследниками один из братьев погибает.

Содержание поэмы характеризуется трагедийной динамикой: смерть мужей Айши - Мухаммада, а затем Масуда, гибель сына Талиба, а затем и смерть самой Айши, повергнутой в отчаянье гибелью младшего сына. Принципиальным для автора становится отражение мотива парадоксальной слабости человека перед лицом судьбы, рока и поворота жизненных обстоятельств. Философская направленность этой мысли отчетливо передана в самом начале поэмы:

Весь мир как шахматы: в нем пешки, короли

Ходить по клеткам шахматной доски

Должны по правилам древнейшей той игры

[Ханинова, Ничипоров 2005: 177].

Как верно отмечает И. Ничипоров, автор поэмы уделяет «повышенное внимание к внутренним мирам героев, вглядывается в их парадоксы, насыщая повествование емкими психологическими характеристиками» [Ханинова, Ничипоров 2005: 188]. Так, в сюжетно-повествовательном плане одно из главных мест в поэме занимает тема материнской трагедии. Поэт с затаенной скорбью отражает страдания матери, вынужденной по воле династических законов выбрать одного из сыновей на роль правителя. Трудность выбора, мучительное душевное состояние отражает речь героини, близкая к афористичной:

Как выбрать? Оба сына хороши.

Сжимает болью сердце у Айши.

$<\ldots>$

«Два сына - две руки. Какая же важней?

Какую отними, не делая больней?..»

[Ханинова, Ничипоров 2005: 180]. 
Такой же крайней лирической напряженностью отличается эпизод, отражающий переживание Айши за исход битвы. Она понимает, что один из ее сыновей все же погибнет. В данном случае Ханинова использует «композиционную форму несобственно прямой речи, когда «всеведущий» поэт-сказитель как бы подхватывает своей речью размышления персонажа» [Ничипоров 2005: 188], передавая тем самым взволнованные мысли и состояние героини:

С высокой башни своего дворца

За ходом битвы следует Айша.

Кто из двоих займет отцовский трон?

Как успокоить побежденного?.. Кто он?..

Но вот вдали уже видны слоны, На башнях их знамена. Только чьи?..

[Ханинова, Ничипоров 2005: 182]

Поэтическая организация всей поэмы подчинена философским размышлениям автора. Прежде всего, это размышление о войне и мире как этапах бытия человечества. Источник войны с ее насилием и хаосом - все тот же: борьба «правд», обязанная дискретной структуре мира, состоящего из мириад несогласованных индивидуальных сознаний. Война предстает как противоестественное событие, спровоцированное низменными помыслами и желаниями человека, главным образом его властолюбием и алчностью.

Наряду с темой войны и мира поэта занимает вопрос о судьбах людей, зажатых в тиски исторических реалий. История в поэме понимается как фатум, силам которого человек не может воспротивиться. Роковые перепитии истории легко вторгаются в судьбу человека, перетасовывая лики и личины своих героев. Автор подчеркивает, что судьба человека, связанная с сущностью мирской власти, может быть трагичной:

Мир может быть подобием войны,

Война - обманом, шумом тишины. 
И лесть, и власть влекомы к слепоте,

Склоняют души юные к тщете...

[Ханинова, Ничипоров 2005: 180].

Таким образом, сквозь конкретику жизненных путей героев просматривается «подводное течение» истории. Прозрение потаенной, подчас роковой связи времен приводит автора к полемическим раздумьям, при этом важен парадоксальный модус авторской мысли, ее тяготение к символическим обобщениям в форме диалога со слушателем:

«Рай ближе к каждому, - сказал Пророк, -

Чем даже на сандалии шнурок.

Но и огонь, - напомнил Мухаммад, -

Такой сосед, что низвергает в ад»

[Ханинова, Ничипоров 2005: 177].

Антигуманная суть войны, ломающая и коверкающая судьбы, отражена автором посредством драматичного диалога Айши и ее старшего сына после гибели Талиба. Автор придает ее речи особую пронзительность и эмоциональность, что углубляет психологическую прорисовку образа (мать становится свидетелем гибели своего ребенка) и передает дух исторической эпохи.

Глаза, поплачьте!.. Им бы не видать

Такого сына...Что еще терять?..

[Ханинова, Ничипоров 2005: 182].

Сюжетно-композиционная структура поэмы, как уже отмечалось, определяется тяготением поэта к афористичной форме высказывания. Достигая подлинно художественной выразительности, эти емкие высказывания, представляющие собой философские обобщения, позволяют Ханиновой заострить поэтическую мысль, точнее отразить ее направление. Так, в диалоге королевы с сыном Гамидом вопросительная модальность материнской речи, связанная с выяснением обстоятельств гибели младшего сына, отражает и извечные вопросы о правде и лжи: 
Как верить я могу тебе, Гамид?

Как мне с тобою без Талиба жить?

Правдивый праведен всегда, Ложь - мать распутства и греха

[Ханинова, Ничипоров 2005: 183].

В русле восточной поэтической традиции рассматривается и вопрос о метаморфозах жизни, драматизме бытия человека, находящегося во власти жестокого рока.

Присутствие авторского голоса, проявляющегося в потоке мыслей героев, в их душевных переживаниях и диалогах, совершенно очевидно в поэме. Как пишет И. Ничипоров, «подобная активность лирического «я», стилевое взаимодействие речевых потоков автора и героев позволяют видеть проникновенное лирическое самовыражение, попытку позиционировать экзистенцию современной личности в многовековом духовно-культурном пространстве Востока и Запада» [Ханинова, Ничипоров 2005: 190].

Образ шахмат - центральный в поэме. Именно за шахматной доской, разделенной на клетки, умирает Айша. Расставляя вырезанные из кости фигуры воинов, боевых колесниц и слонов, изображая весь ход битвы, она тщетно пыталась найти другой исход сражения - возможно, гибель одной из армий, но не ее сына:

Две армии на шахматной доске -

Стратегия и тактика в игре.

Свет солнца на фигурах. Вот Гамид Фанфарами победу возвестит.

Мерцание луны. Теперь Талиб

Останется в живых: он не погиб

[Ханинова, Ничипоров 2005: 185].

Два лагеря, по шестнадцать фигур и пешек с каждой стороны, застывших в безмолвии на 64-клеточной доске, становятся «знамением неотвратимого перста судьбы, действующего в земной 
жизни» [Ханинова, Ничипоров 2005: 192]. Древнее персидское словосочетание «Шах мат - властитель умер. Вечный шах. / Ничья здесь невозможна, о Аллах!» [Ханинова, Ничипоров 2005: 193] задает всему произведению заряд философских раздумий. Главная мысль поэта заключается в том, чтобы через напомнить о «таинственной метафизике власти» [Ханинова, Ничипоров 2005: 191] и об антигуманной сути войны. Через призму метафорического образа шахмат автор размышляет над фатальной предопределенностью жизненных обстоятельств. Человек - раб судьбы, пытаться изменить ее, воспротивиться ей абсолютно невозможно. Она не знает «меры и цены»:

Так родилась древнейшая игра.

Одна из версий - как труды ума.

И что здесь от искусства? От борьбы?

Фигуры шахмат - формула судьбы

[Ханинова, Ничипоров 2005: 186].

Таким образом, на уровне философских обобщений поэма «Формула судьбы» глубока драматична. Шахматное сражение двух соперников, представляющее собой необычайно сложную и одновременно единую систему, - самое благородное, которое человечество когда-либо знало: без крови, без потерь, удивительное по глубине мысли, отражению страстей. В поэме же оно, напротив, отражает всю жестокость земной жизни людей, с ее перипетиями борьбы, логикой и антилогикой, давая тем самым возможность для масштабных философских обобщений и открывая широкие горизонты для художественного осмысления.

Как справедливо отмечает А. А. Бурыкин, к истокам и духовным сокровищам Востока Р. Ханинова подошла «с солидным активом, в том числе с реалистическим осмыслением места буддизма в культуре, литературе и духовной жизни современных калмыков» [Бурыкин 2005: 38].

Обращение к истокам буддийского знания является одной из особенностей поэзии Риммы Ханиновой. Поэт, как подчеркивают исследователи, предприняла одну из первых в новейшем 
литературном процессе Калмыкии попыток художественного осмысления буддийской философии, религии и культуры. Здесь можно заметить, что на момент обращения поэта к данной теме (в последнем десятилетии XX в.) в постсоветском обществе широко развивались процессы возрождения национальных культур. В Калмыкии в это время особое внимание уделялось проблемам восстановления статуса языка и ревитализации буддийских институтов. Поэтому к проблемам возрождения религии автор обращается как к составной части процесса возрождения национальной культуры в целом.

Буддийская тема представлена в творчестве поэта многожанрово: это стихотворения «Монах тибетский пред собой метет...» (1993), «Тибет» (1994), «Обычай предков - сдержанность всех чувств» (1994), цикл буддийских басен (1994), цикл стихов «Буддийский пантеон» (1994), поэмы «Час речи» (1998), «Солнечный Лев» (1998-1999), «Чайный куст» (2002), а также пьесы «Легенда о первом джангарчи» (2008) и «Небожитель и младенец» (2009).

Некоторые проблемы осмысления буддийских ценностей в творчестве Р. Ханиновой затрагивались в статьях А. Бурыкина «Поэт, судьба и время», И. Ничипорова «Эпическая традиция современной калмыцкой поэзии: философские поэмы Риммы Ханиновой», Э. М. Ханиновой «Поэма Риммы Ханиновой «Солнечный лев» в аспекте буддийских традиций воспитания», С. В. Шовадаевой «Буддийский мир в поэзии Риммы Ханиновой», А. В. Музаевой «Поэзия Риммы Ханиновой в аспекте буддийских традиций воспитания».

По справедливому замечанию А. В. Музаевой, в произведениях буддийской тематики Римма Ханинова через сюжеты проецирует, как правило, дидактический аспект. Пример тому - стихотворение «Монах тибетский пред собой метет...» (1993), ставшее первым подступом поэта к осмыслению буддийской философии с ее концепцией гармонии мира. В основе произведения - мотив любви, сострадания, милосердия ко всему живому и сущему: 
Монах тибетский пред собой метет -

Так защищает мелкую живинку,

Которая случайно попадет

Под башмаки неведомой соринкой.

Столь бескорыстен трогательный жест,

Так - несмотря и вопреки - в судьбу вмешаться,

Чтобы одну из множественности бед

Метлою по пути недосчитаться

[Хонинов, Ханинова 2010: 257].

Согласно буддийскому учению все существа находятся в круге перерождений, а лишение жизни - один из главных недобродетельных поступков. Однако действия человека не всегда бывают осознанными, здесь мы имеем в виду соотношение мысли человека и его поступка:

Всегда ли добродетельный порыв -

Первичное вне разума движенье, -

Суть милосердья сохранив,

Спасителен своим прикосновеньем?

[Хонинов, Ханинова 2010: 257].

Поясняя смысл этого стихотворения, Р. Ханинова привела в качестве иллюстрации пример из книги А. М. Пятигорского «Мышление и наблюдение. Четыре лекции по обсервационной философии» [Москва, 2002]. Современный философ, анализируя миф о слепом Чаккхупале, растоптавшем во время своих прогулок мириады насекомых, подчеркнул, что Будда не увидел в этом мысли об убийстве и оставил отшельника в монашеской общине. В этом мифе мысль об убийстве и есть убийство, и знание о физическом акте убийства не имеет никакого значения, поскольку сам этот акт наблюдается как мышление, оставаясь этически (здесь кармически) нейтральным, но при этом Будда знал Чаккхупалу как в этом, так и в предыдущих его рождениях, то есть знал его «личность».

«Всегда ли добродетельный порыв - первичное вне разума движенье... спасителен своим прикосновеньем?» [Хонинов, Хани- 
нова 2010: 257]. Вопрос, поставленный поэтом, риторичен: лишь намерение определяет возникновение действия. Обратная последовательность логически приводит к тому, что непреднамеренный поступок не становится кармически значимым, не имеет последствий для последующей жизни.

Как отмечает В. И. Корнев, карма «считается чрезвычайно сложным законом, характер проявления которого полностью осознавал только Будда» [Буддизм 1992: 144]. Согласно буддийскому учению жизнь человека определяется совокупностью деяний, совершенных им в течение всей жизни. Однако непреднамеренное действие (деяние, поступок) не считается «разрушительным», ведущим к ухудшению положения в будущем, ибо «в конструировании кармы главная роль принадлежит мысли, так как слова и действия являются вторичными по отношению к сознанию» [Корнев 1992: 144].

Таким образом, карма, согласно буддийскому учению, — это не предопределенность судьбы, не рок, а импульсы, задающие ритм и сферу последующей жизни. Сущность импульса состоит в мыслительном процессе, и потому отсутствие намерения есть отсутствие импульса, имеющего следствие. Поэт приходит к выводу, что подлинная бодхичитта ограждает человека от следствий поступков, совершенных случайно, вне намерения. Такова философская проблема, поставленная автором в данном стихотворении.

Римма Ханинова, по ее собственному признанию, человек атеистического мировоззрения. Обращаясь к буддийскому учению в поисках ответа на загадки мироздания, поэт поясняет, что религия ее привлекает, прежде всего, в культурологическом и аксиологическом аспектах. «Буддизм в поэзии Р. Ханиновой - это не храмовый буддизм. Это та художественная форма рецепции религиозных понятий, символов, фрагментов текстов, которая характерна для высших форм искусства в их связи с религией...» [Бурыкин 2005: 28]. В этом смысле цикл «Буддийский пантеон» (1994), один из ранних поэтических циклов в творчестве Ханиновой, представляет собой первое соприкосновение поэта с религиозной тематикой. 
Буддийский канон иерархии божеств включает ранги идамов (личных покровителей), будд, бодхисаттв, дхармапал или докшитов (хранителей веры), локапал (хранителей света). В состав «пантеона» Р. Ханиновой включены божества, представляющие ранг бодхисаттв (Зеленая Тара, Авалокитешвара), дхармапал (ОконТенгри), а также добуддийское божество Белый Старец - Цаган Овген. Источниками знакомства поэта с буддийскими персонажами является как устная традиция, так и буддийская литература, что и отражено в использовании калмыцкого названия Окон-Тенгри (тиб. Лхамо), в обращении к популярным у калмыков божествам - Зеленой Таре и Авалокитешваре как к Ноган Дара Эке и Арьябуле. Двуязычность поэта отражена в использовании двойного названия божества «Белый Старец - Цаган Овген».

Стихотворения цикла «Буддийский пантеон» (1997 г., сборник стихотворений «День влюбленных») являются своеобразным поэтическим обращением к буддийскому пантеону божеств. Они представляют собой описания, особенность которых состоит в том, что, с одной стороны, они соответствуют каноническому изображению божеств, что позволяет читателю визуализировать их, как бы «рассмотреть» вслед за автором все детали их изображения; с другой - раскрываются их мифологическое происхождение, сущность, назначение и функции.

Цикл «Буддийский пантеон» открывает стихотворение «ОконТенгри». Окон-Тенгри входит в число десяти гневных божеств защитников буддизма, является повелительницей демонов, искоренительницей ядов. Характеристики, которыми она наделяется в мифах и народных интерпретациях, разнообразны. Калмыки считают ее защитницей, светлой богиней возрождения жизни, провозвестницей весны. Согласно древнему поверью, из сострадания ко всем живым существам богиня Окон-Тенгри убила своего сына, так как младенец, перевоплотившись в великана, мог уничтожить весь мир.

Автор подробно описывает богиню, какой ее изображают в соответствии с буддийским каноном, при этом многие детали, упомянутые автором, верно передают гневный характер божества: 
Когда дар природы, дитя, увидеть был должен сей свет, нимало себя не виня, сдержала инстинкт свой, завет, и сына убила, ведь он был призван губить людской род.

Злодейством ум так потрясен, что им искривлен ее рот, а кожа, став синею вмиг, утратила свежесть и цвет, глаз выкатив дикий, как вскрик, докшита явилась в ответ [Хонинов, Ханинова 2010: 237].

Глаз мудрости, расположенный на лбу, о котором упоминает автор, кроме обычного зрения обеспечивал виденье прошлого, настоящего и будущего. В процессе повествования упоминается и ездовое животное (мул) богини, и кожа ребенка, которую она содрала с мальчика, использовав ее в качестве покрова (в других интерпретациях в качестве седла):

Свирепое то божество -

защита людей от врагов, ногою свое естество -

всю кожу ребенка - покров

мула белого сжав, торопит на землю весну, которую задержал коварный Эрлик-номин-хан [Хонинов, Ханинова 2010: 237].

Жертвенность матери во имя человечества не находит отклика в душе поэта. Так, в конце повествования автор задается вопросом, но оставляет его открытым, показывая при этом свое отношение к героическому, но поистине трагическому подвигу-самопожертвованию:

О женщина, спасшая всех, палач ты иль жертва? 
Как знать...

Но твой материнский грех

мне с горечью сложно признать

[Хонинов, Ханинова 2010: 239].

Таким образом, основная идея автора заключается в том, чтобы раскрыть амбивалентность, «дилемму» характера богини Окон-Тенгри. Жестокая, карающая, «свирепая», она же - «защита людей от врагов», спасительница, дарующая все блага тому, кто к ней обращается:

Дилемма добра и зла -

критерий ума и чувств, -

как мертвая вроде зола

скрывает свой уголь буйств [Хонинов, Ханинова 2010: 239].

Стихотворение «Белый Старец - Цаган Овген» посвящается божеству, которому поклоняются все монголоязычные народы. Он считается хозяином мира, «хранителем жизни и долголетия, благоденствия всего живого» [Батырева 2008: 62].

Название стихотворения «Белый Старец - Цаган Овген», кроме того, что указывает на двуязычность поэта, как нельзя лучше отражает как знание им народных представлений об этом образе, так и знакомство с буддологической литературой, в которой стереотипной формой написания является именно форма «старец», восходящая к монгольскому слову «эбуген» — старик:

Хозяин мира, года и земли,

О Белый Старец, милости яви.

Ты - покровитель наших бренных лет,

продли сей жизни заповедный след.

Твой посох стерт, и зелен древа цвет, вкус персиков с него изведан много лет, олень доверчив - долог жизни путь, искомая существованья суть. 
В той книге судеб - никогда не счесть моя страница, вероятно, есть, и тайный смысл - верю - бытия, в котором знак местоименья «я»

[Хонинов, Ханинова 2010: 245].

Глубинный смысл стихотворения - не только «освоение» образа через анализ иконографического канона (экфрасис), философское рассуждение, но и творение молитвы-мантры, обращение к божеству, предполагающее монологическую форму при имплицитном диалоге. Форма обращения, прежде всего, определяется этикетными нормами культуры.

Миф, связанный с божеством Цаган Аав, имеет несомненную художественную ценность и содержит в себе основополагающие постулаты религиозной нравственности. Белый Старец - божество, являющееся носителем общего блага. Мудрые заветы, которые ему приписываются в сутре «Цаган Аав» (почтительность к родителям, вера в Три Драгоценности, добродетельность, основанные на милосердии и сострадании), отвечают канонам буддийского вероучения, являются «залогом чистоты всех помыслов, надежды и мечты»:

Недаром Будда повелел ученикам воздать тебе все почести. И нам вновь обращаться к твоему уму, изгнать из сердца суету и тьму...

[Хонинов, Ханинова 2010: 247].

Для человека, изгоняющего «из сердца тьму и суету» и «смуту мыслей, страстей» и стремящегося к «свету», это означает стремление к познанию основных истин - десяти главных добродетелей буддизма, поскольку «тьма» не может быть избрана теми, кто прикоснулся помыслами к добру, состраданию и милосердию буддийского учения.

Культ Белого Старца в культуре монгольских народов шире, чем те его черты, которые отражены в стихотворении Р. Ханино- 
вой. В традиционных представлениях калмыков он присутствует в двух ипостасях: как Всемирный Белый Старец - «покровитель калмыков, дарующий жизнь, хозяин времени - Делкян Эзн Цаһан Авһ» [Бакаева 2003: 212] и как һазр усна Цаһан Авһ - «хозяин всех ова калмыков. Он же является покровителем всех живущих на данной территории» [Бакаева 2003: 212].

Как мы видим, для Р. Ханиновой важна характеристика персонажа в рамках буддийского учения, однако за пределами ее рассуждения остается понимание божества как прапредка и покровителя всех монгольских народов. Думается, это определено вниманием поэта к буддийской проблематике.

Во всем цикле обращает на себя внимание форма обращения в предпринимаемом поэтом формально близком ритуальном общении с божествами. Автор обращается к Белому Старцу: «mы покровитель наших бренных лет, продли сей жизни заповедный след»; «mы - покровитель счастья и семьи»; к Окон-Тенгри: «небесная дева огня <..> mbl - тайна теперь для меня»; к Зеленой Tаре: «спасительница Тара, mы в почете...» и т. д.

Неоднократное употребление местоимений «mbl», «твой» указывает на их стереотипность в формах обращений, избираемых поэтом. Ритуальное поведение, описываемое в произведениях цикла «Буддийский пантеон», должно предполагать автоматизм выбора этикетных форм. Сочетание высокого стиля в обращении к божествам с местоимением в единственном числе не соответствует нормам калмыцкого этикета, в системе которого существует традиционное представление об обязательном использовании формы «вы» (калм. $m a$, , тадн) по отношению к божеству, что выражает почитание и преклонение перед святыней.

Форма обращения «mbl», «твой» является этикетным и ритуальным обращением в православных молитвах: «Господи, прости и помилуй нас», «боже мой», «да святится имя твое» и т.д. В буддийском цикле Р. Ханиновой форма обращения «ты» служит, скоpee, в качестве ближней коммуникационной позиции и отражает также в некотором смысле евразийский вектор ее поэзии, пересечение восточных и европейских аспектов. 
В цикле «Буддийский пантеон» отражены, естественно, далеко не все ранги буддийской иерархии, выделены наиболее знаковые для калмыков ключевые персонажи: Окон-Тенгри, Зеленая Тара, Белый Старец, Авалокитешвара. Обращение поэта к определенным образам пантеона продиктовано стремлением осмыслить философию буддийского вероучения, что стало особенно необходимо в период возрождения духовной культуры народа, его религии. Осмысляя принципы буддийской философии, истин благородного срединного пути, поэт приходит к выводу о том, что в основе буддийской религии, как и всех иных, - заложены общечеловеческие ценности: любовь, сострадание, милосердие.

Поэма «Час речи» является ярким примером необычного синтеза европейской и восточной литературных традиций. Так, эпиграфами к поэме служат строки, взятые из произведений известных русских поэтов Ф. Тютчева и И. Бродского, а начало вступительного эссе («Вначале был звук, потом - слог, затем - текст») открыто перекликается с первой строкой Евангелия от Иоанна (Новый завет): «В начале было Слово, и Слово было у Бога, и Слово было Бог». В то же время на протяжении всего текста произведения «национальный характер автора проявляется в устремленности поэтического слова к ментальности своего народа», прежде всего, на уровне употребления устойчивых выражений, то есть «элементов национального речемыслительного стандарта» [Джушхинова 2003: 45], в которых содержится ценностная картина мира калмыцкого народа, истоки его мифопоэтического мышления.

Поэма, написанная по мотивам малоизвестной народной калмыцкой сказки «Капли счастья», привлекала внимание многих исследователей творчества Ханиновой - И. Ничипорова, В. Колчанова, И. Козловой, Б. Бюрчиевой и др. По мнению А. Бурыкина, «эта поэма по-своему продолжает цикл стихов по буддийским мотивам, связанных единой темой и единым стилистическим решением, той формой, которую в совершенстве освоила поэтесса и которой широко пользуется в новых произведениях» [Бурыкин 2005: 37]. 
Произведение наполнено философскими размышлениями автора о смысле жизни при всей бренности человеческого бытия. В этой связи неслучайно даны упомянутые выше эпиграфы: строки из стихотворений Ф. Тютчева и И. Бродского, в которых превалирует мысль о высшей цели и смысле человеческой жизни, завершаемой смертью. Для поэта в особенности это могут быть Мысль, Слово - непреходящие, вечные ценности, составляющие бессмертное творение.

Именно эта мысль звучит в устах Хормусты, почитаемого как глава небожителей - тенгриев:

Тогда лишь связь всех поколений крепит земную вашу ось.

И мысль - парадокс со-мнений всему свой смысл придает.

Ты мысслишь, значит — существуешь.

Без плоти дух так одинок.

Ты мыслишь, значит — торжествуешь

над всем, что бренно: ты высок...

[Хонинов, Ханинова 2002: 39-40].

О мысли, выраженной в Слове, повествуется и в финале произведения:

Час речи пробил. Но не вечер:

внимает Времени глагол.

Час речи. Часть судьбы и встречи

Час речи... Кто ее обрел [Хонинов, Ханинова 2002: 41].

В поэме «Час речи» перед нами предстают персонажи двух миров материального круга перерождений. Согласно буддийскому вероучению, это миры человеческий и божеств (тенгриев). Но в содержании произведения данные персонажи выступают как представители иной дихотомии: земного и небесного миров. Хормуста - предводитель тенгриев, обитатель мира божеств, согласно буддийской космологии, является персонажем одного из мате- 
риальных миров, однако именно народные представления о божестве оказали влияние на появление мотива его пребывания в мире, который трактуется как посмертный, загробный. Тем не менее местопребыванием Хормусты указывается гора Сумеру — центр мира. Налицо сочетание буддийских и добуддийских религиозных представлений калмыков. Обратившись к первоисточнику, осмыслением которого и является поэма, - сказке «Капли счастья», записанной в XIX в. Н. Бадмаевым, обнаруживаем, что локус небожителя - некая «горная обитель». Р. Ханинова конкретизирует персонаж, им оказывается в сюжете Хормуста, глава тенгриев. Автор корректирует согласно своему замыслу космологические буддийские константы в соответствии с народными традиционными представлениями, согласно которым посмертный мир находится выше, чем срединный мир - мир живых (ведь недаром выражение «вознес кости», происхождение которого связано с древним видом погребений, обрело значение «погребен достойно», «ушел в высший мир»). Таким образом, противопоставление двух персонажей как представителей двух миров основано не на буддийском представлении о мирах сансары, а на традиционных калмыцких религиозных воззрениях на посмертный мир.

Тем не менее народные мировоззренческие позиции тесно связаны с буддийскими. Именно потому, как объясняет сама Р. Ханинова, сказка привлекла ее возможностью выявить заложенный в ней потенциал философского осмысления жизни, уточнить ее буддийский аспект в народном его понимании.

Философская направленность авторской мысли обозначается в самом начале поэмы постановкой волнующих проблем бытия:

В чем смысл земного бытия?

Час речи пробил не спеша... [Хонинов, Ханинова 2002: 25].

Произведение построено в форме диалога, что является характерным для поэтического стиля автора. Завязкой сюжета становится смерть ребенка: 
...дитя, не зная, умирает,

без прегрешений, без обид,

лишь плоть, слабея, замирает,

душа плутает в ней, болит... [Хонинов, Ханинова 2002: 26].

Образ умершего младенца в «Часе речи» наделен большой художественной силой. Будучи уже «в раю» (так в поэме, в сказке же местом действия определяется «горная обитель»), дитя обнаруживает сильную привязанность к дому и семье. Ребенок в традиционных представлениях калмыков является частью поколения, которое есть связующее звено в родовом клане, он - часть потомков, ведущих начало от общего предка. Потому в поэме, как и в сказке, закономерно появляется мотив заботы и беспокойства о родителях, оставшихся без первенца, попытка помощи им:

- Пусть будут счастливы родные.

Я так мечтаю об одном -

чтоб не погас очаг отныне, чтоб теплым был всегда мой дом

[Хонинов, Ханинова 2002: 30].

Младенец все еще связан с землей, срединным миром: «... теперь в раю блажен я, лучезарный, но лучше на земле, поверь» [Хонинов, Ханинова 2002: 28].

Помимо того, что ребенок - это носитель всего чистого, нравственного, что заложено в человеке с детства, он символизирует и само страдающее человечество, и веру в будущую гармонию:

- Душа твоя, дитя, бессмертна.

О чем жалеть? Там, на земле, все люди бренны, они - смертны:

беспомощны они во зле [Хонинов, Ханинова 2002: 28].

На что мальчик отвечает:

- Они, творец, несовершенны:

добро в них борется со злом -

высоты необыкновенны, падения переживем [Хонинов, Ханинова 2002: 28]. 
Ребенок в традиционных религиозно-мифологических представлениях калмыков является существом, взаимосвязанным с человеческим и иным мирами. Его появлению на свет предшествует период внутриутробного развития, включаемый в возрастную хронологию. И тем не менее он является «чистым существом», подобным «чистому листу». В данных воззрениях философские взгляды буддизма на новорожденного и народные представления о нем смыкаются.

На протяжении всего развития действия в поэме «Час речи» повелитель небесных тенгриев Хормуста, унесший душу младенца в далекую священную «обитель богов» - на гору Сумеру, ведет с ним спор о счастье. Попавший в его власть пытается «прояснить» вечный вопрос о существе ценностей человеческого бытия, его душа жаждет положительного смысла, ради которого стоит жить.

Согласно сюжету народной сказки, в поэме основные действия связаны с действиями, совершаемыми ребенком с «волшебными каплями», содержащимися в подаренном небожителем кубке. Через ниспослание первых трех божественных «частиц счастья» близким ребенка, оставшимся в срединном (земном) мире, проверяется истинность таких категорий, как богатство, слава, любовь. Четвертая капля несет за собой «забвение», «покой и плоти и души». В сказке «Капли счастья» небожитель уточняет его словом «нирвана», вступающим в некоторое противоречие со значением первого слова: слово «забвение» означает «утрату памяти о чем-нибудь, пренебрежение чем-нибудь, о чем нужно помнить» [Корнев 1992: 251]. Нирвана же, как одно из основополагающих буддийских понятий, означает состояние, свободное от идей, беспокойства, страданий и другого рода «скверн» земного бытия, состояние «полного освобождения». «В буквальном смысле, оно означает отсутствие паутины желаний (ванна), соединяющей одну жизнь с другой» [Жуковская 1992: 192]. Буддийское учение о нирване, то есть о высшей ступени блаженства, которое достигается постоянным стремлением к добру, сродни идее морального совершенствования как единственно верного пути к достижению личного и общего блага. 
Философский смысл сказки в том, что истинные ценности заключаются не в благополучии человека, не в обилии денег и не в высоте положения. Кратковременное удовольствие, которое доставляют материальный достаток и мирская слава, постепенно сменяют «тоска, измены, ссоры», «брань, побои»:

Текут так дни, как в лунном свете

журчат ручьи вдали, в степи.

Уже пресытились всем этим

родители, как старики [Хонинов, Ханинова 2002: 31].

Третья волшебная капля, несущая любовь, также не приносит радости и счастья. Это чувство оказывается, увы, недолговечным:

Любовь лишь молодость питает,

страсть мало ею дорожит,

как снег на солнце, она тает

и от забот всегда бежит [Хонинов, Ханинова 2002: 36].

Что же касается «любви родителей», то «...что же, / песок лишь в тягость - не родня.// Но для детей всего дороже - // чуть вырасти - весь мир тогда» [Хонинов, Ханинова 2002: 37], — так рассуждает мудрый Хормуста. Условно «важные» критерии человеческого существования - не источники истинного мира, стабильности и счастья, они преходящи. На смену богатству, славе, привязанностям со временем приходят страдания. Это поясняет мальчику властитель тенгриев:

- Ты убедился, что страданья, на кончике желаний всех.

На том стоит все мирозданье

и счастье ваше, человек [Хонинов, Ханинова 2002: 39].

Так, размышляя над вековечными загадками земного бытия, автор постепенно переходит к основам буддийского вероучения.

Согласно основным принципам буддизма, чтобы прожить жизнь со смыслом и при этом освободиться от страданий, человеку необходимо породить в себе бодхичитту и тем самым устремленность к Пробуждению, основанную на любви, милосердии и 
сострадании. Причины страданий заключаются в том, что человека переполняют неисчислимые желания. Поэт объясняет:

Источников страданий два

в круговороте бытия:

поступки, скверны все ума

(желание и злоба «я»-

основа тех основ) — их тьма.

$<\ldots>$

И истинные пресеченья

есть состояние тех действ,

что приведут к исчезновенью

истоков боли и злодейств [Хонинов, Ханинова 2002: 40-41].

Людям кажется, что если они заполучат то, что желают, они будут счастливы. Однако счастье это оказывается недолгим. «Пресечение страстей», о котором пишет автор, заключается в уничтожении «источников» страданий.

«Чтобы избавиться от страданий и обрести счастье, - утверждает Его Святейшество Далай-лама XIV Тензин Гьяцо, нет иного пути, кроме как устранить в потоках сознания живых существ причины, порождающие страдание, и создать в этих потоках причины счастья» [Далай-лама 1991: 55]. Иными словами, чтобы быть счастливым, нужно жить как можно проще, иметь как можно меньше желаний и довольствоваться тем, что есть.

В речь небожителя автор поэмы вкладывает четыре благородные истины буддийского вероучения, представляющие собой жизненные ориентиры, с помощью которых человек может избавиться от привычки потакать своим желаниям:

Четыре истины у Будды:

страданья истинные есть, источники страданий-будней

и пресечение страстей,

пути к познанью всех вещей [Хонинов, Ханинова 2002: 40].

Учение «О четырех благородных истинах» проявляется в правильной речи, правильном мышлении, правильном образе жизни и 
других аспектах «Правильного, или Срединного пути», - одним словом, в том, как мы действуем. Таким образом, «свет», который помогает «обрести счастье» и «приводит к исчезновению» страданий, лежит на пути к Просветлению, корнем и фундаментом которого являются любовь и сострадание:

И устремленность к Просветленью

для блага всех живых существ

становится и вдохновеньем

всех добрых и гуманных действ

[Хонинов, Ханинова 2002: 41].

В конце поэмы в перефразированном виде использована молитва, которую привел в своей Нобелевской лекции Его Святейшества Далай-ламы XIV. Эта молитва, по словам духовного иерарха буддизма, вселяет в него «великую решимость и вдохновение» [Далай-лама 1991: 91]. Думается, что в ней сконцентрирована не просто гуманистическая идея буддизма, но и весь смысл его практики:

Покуда длится пространство,

Пока живые живут,

Пусть в мире и я останусь

Страданий рассеивать тьму [Далай-лама 1991: 91].

В поэме автор вкладывает перефразированные слова молитвы в уста небожителя:

Покуда длится здесь Пространство,

покуда Время здесь идет,

противоречивость в постоянстве

Добра и Зла давно живет,

и я, Хормуста, в ваших буднях,

поверив вашему уму,

присутствовать незримым буду, рассеивать страданий тьму...

[Хонинов, Ханинова 2002: 41]. 
Посредством динамичного сокровенного диалога центральных героев поэмы Р. Ханинова обращается к актуальной во все времена проблеме взаимоотношения человека и мира. Она раскрывает представление о счастье с позиций аксиологии буддизма. Но источник, к которому обратился калмыцкий поэт, определил неизбежное слияние классических и народных буддийских представлений о ценностях бытия.

Активно прослеживается на протяжении всей поэмы ее фольклорное начало. Связь с калмыцким фольклором, помимо самого сюжета, также проявляется в многочисленных калмыцких словах, не переведенных на русский язык, но разъясняемых в примечаниях (келмерчи - 'рассказчик', йорял - 'благопожелание', тенгрии - 'боги, небожители'), отсылках к народным пословицам, воплощающим проверенную мудрость многих поколений:

...Справедливость -

надежда слабых на судьбу.

Кому она дарила милость?

Слепа ведь судя по всему.

И потому слепой корове

воды показывать не впрок,

и в каждом высказанном слове

искать прицел, спустив курок

[Хонинов, Ханинова 2002: 33].

Р. Ханинова, сгущая смысл пословиц, не только перефразирует их, но и разъясняет в свете осмысливаемых ею философских буддийских истин. В этом авторском осмыслении народной мудрости сквозь призму буддийской философии прослеживается стремление к объединению философии и народного опыта в единое целое, которое является для калмыцкого поэта искомым наследием.

Слово для поэта есть философское осмысление смысла жизни, основанное на народной традиции и буддийском знании. Истинные ценности для автора «Часа речи» - не только буддийские философские положения, не только религиозная аксиология. 
Преемственность поколений, культуры - другая ценность бытия, остающаяся для бренного мира «мирской истиной всегда». И лишь Мысль — человеческое качество, отличающее, согласно буддийскому учению, лишь представителей мира людей, является способом и формой парадоксального сочетания «со-мнений». Истина, по мнению Р. Ханиновой, заключается сочетании мирских ценностей, которые может узнать человек, и философских открытий. Говоря иначе, человек остается носителем культуры, которая есть комплекс традиций, и буддийское наследие осмысляется через призму жизненных приоритетов и этнической культуры.

Осмысление классической буддийской философии связано в творчестве Ханиновой и с трансформацией буддийских басен и притч. Поэтический цикл «Наследство» (1994) включает в себя тринадцать поэтических басен, созданных по мотивам буддийских басен, и два стихотворения по мотивам индийских легенд.

Следует заметить, что жанр басни в калмыцкой литературе достаточно редок. Серьезная заслуга в его развитии принадлежит двум калмыцким писателям: Тимофею Бембееву и Михаилу Хонинову. Остроумные, злободневные басни обоих авторов сразу же завоевали признание читателя, сделали их имена популярными. В настоящее время Римма Ханинова, пожалуй, единственная, кто продолжила освоение данного жанра. Для нее это стало началом осмысления культуры Востока. Написанные в художественных традициях указанных жанров басни Ханиновой имеют несложные сюжеты, тяготение к морализации, выраженный дидактический оттенок. Поэт высмеивает и критикует уродливые явления жизни и человеческие пороки: хитрость, жадность, лень, тщеславие, трусость, глупость, невежество. Причем делает это просто и доходчиво, понятным языком, преимущественно в диалогической форме, отражая морализаторско-поучительные устремления в аксиологическом ракурсе.

Цикл «Наследство» открывает стихотворение «Вкус жизни», в основе которого известная притча о путнике, раскрывающая размышления автора о ценности и смысле человеческой жизни. 
Оказавшись между тигром и пропастью, человек, выбрав из двух зол меньшее, вцепившись в виноградную лозу на краю пропасти, увидел наверху двух мышей, подгрызающих корни спасительного стебля. А еще ближе к нему виноградную гроздь, которую и вкусил перед гибелью.

В этой известной буддийской притче Ханинова увидела аналогию человеческой жизни с неизбежными страданиями, опасностями и смертью, самым драматичным и непоправимым событием в жизни личности. Содержание притчи гласит, что реальность жизни амбивалентна и порождает разные, и даже противоположные, следствия. Радость и грусть, наслаждение и страдание, жизнь и смерть, то, что называется «экзистенциалиями» человека, если воспользоваться хайдеггеровским термином, поскольку они составляют часть самой конституции человеческого существа, являются как бы циклом его жизни. Из них факт смерти является абсолютно неизбежной реальностью и самым очевидным свидетельством ограниченности, конечности и зависимости человека. Не во власти человека жить или умереть. Он не хозяин, а распорядитель жизни и ее свойств. Осознание границ человеческого существования, понимание и переживание скоротечности жизни позволяет сделать вывод о том, что жизнь дана человеку как высший дар, как нечто неизмеримо ценное и подлинно драгоценное. И потому мы должны высоко ценить ее и прожить со смыслом, а не отдаваться потоку повседневности и сиюминутности, бездумно растрачивая свой стартовый капитал, тот изначальный резерв жизни, который есть у каждого.

«В инварианте притчи один преступник, застигнутый преследователями, спускался по лозе в колодец, где внизу его ждала змея, а наверху прибежавшие мыши грызли лозу. Когда он поднял голову, в рот ему упали капли меда из пчелиного улья. Забыв об опасности, он стал смаковать лакомство. В этой притче «один» означает одиночество человека, рождающегося в этом мире и затем умирающего. «Преследователи» и «ядовитая змея» — это тело, источник различных желаний. «Лоза в заброшенном колодце» зна- 
чит жизнь человека. Две мыши, «белая и черная», - это время. Под каплями пчелиного меда подразумеваются наслаждения жизни (Учение Будды)» [Шаводаева 2005: 6]. При этом, как отмечает С. В. Шаводаева, размышляя о скромном выборе, поэтесса в осмыслении человеческого бремени не дистанцируется от лирического героя («Не мне ли, путнику, не знать, что путь конечен, - он вне игр»), а солидаризуется с ним [Шаводаева 2005: 6]:

Да можно руки вмиг разжать -

две мыши труд не обессудят.

Но как тогда, скажи, узнать

тот вкус, который жизнью будет? [Ханинова 1997: 211].

В басне «Наследство» Р. Ханинова высмеивает такие человеческие пороки, как глупость и жадность, неистовую жажду богатства. Перед смертью отец завещает детям «разделить все наследство с миром пополам» [Ханинова 1994: 211]. После его смерти между сыновьями начался «спор-дележ»: кому и сколько взять? В итоге братья «остались ни с чем на руках» [Ханинова 1994: 212]. Все было поделено ровно «пополам»: платья, посуда, скотина. Автор показывает, что овладевающая людьми страсть к материальным благам доходит до абсурда. По ее мнению, счастье выпадает лишь тому, кто умеет властвовать над своими желаниями, - для человека это и разумно, и полезно. Можно заметить, что, хотя аллегоричен весь смысл басни, в обрисовке героев басни нет аллегоризма, но есть обобщение, типизация, которые достигаются благодаря психологической точности в воспроизведении характеров.

Ханиновская идея морального совершенствования в этом произведении подводит к глубинным положениям буддийской философии. Мирские желания и удовольствия приводят к страданиям. Обретение счастья в богатстве невозможно. В неведении и непонимании этого человек постепенно становится рабом гнева, страстной привязанности, безрассудства и других отрицательных эмоций. Вся жизнь проходит в погоне за иллюзорными объектами мирского счастья. И пока человек не очистит свое сознание, пока 
оно будет контролироваться страстью, неведением, с ним будут происходить ужасные вещи. Согласно положениям буддийской теории, человеку необходимо освободить свой ум от неведения и очистить сознание, что достигается только с помощью мудрости и сосредоточенности (концентрации ума). Если же ум свободен от заблуждений, человек достигает настоящего постоянного счастья, которое всегда будет с ним.

Таким образом, основная идея басен Р. Ханиновой - призыв к нравственному самосовершенствованию и самопожертвованию в соответствии с этическим кодексом буддизма. В них словно отражены все законы жизни и дано исчерпывающее понимание окружающего мира. Басни Ханиновой современны, поскольку пороки, высмеиваемые автором, характерны для любого времени, так же, как идея самосовершенствования человека в качестве единственно верного пути к достижению личного и общего блага. При этом автор - не сухой, рассудительный моралист, а подлинный поэт, доносящий свои дидактические обобщения через емкие сюжеты и яркие разнообразные жизненные характеры.

В произведениях Р. Ханиновой отражается два уровня религиозных воззрений, с которыми знакома поэт: адаптированных к повседневной жизни и уровню народных знаний и канонических, почерпнутых из буддийской литературы. Обращение к буддизму как части национальной культуры есть возвращение поэта к собственным истокам, осмысление своих корней. Именно этим можно объяснить выбор основных объектов в цикле «Буддийский пантеон». Но восстановление буддийских ценностей к поэту приходит не через обрядность, домашнюю религиозность - Р. Ханинова остается верной атеистическому мировоззрению. Она знакомится с буддийским учением теоретически, постигая его как новое знание. И синтезирует это знание с тем бытованием буддизма в этническом самосознании, которое могла наблюдать среди представителей старшего поколения. 
Как показывает анализ творчества Р. Ханиновой, ее литературное дарование многогранно. Она с виртуозным мастерством пишет и большие произведения (поэмы, баллады, циклы), и философские миниатюры. Почти все жанры поэзии получили в ее творчестве оригинальное звучание, отражая не только широту и масштабность мысли, но и демонстрируя раскованность и самобытность манеры образного воплощения действительности.

Главной особенностью поэтики автора являются культурноисторические параллели, ассоциативность образов, включение элементов «чужого слова» в структуру поэтического текста. При этом Р. Ханинова «демонстрирует осознание, принятие и воплощение основного закона поэзии: всякий поэтический текст есть память о поэтических произведениях, созданных до него... $<. .>$ ее поэзия чужда вторичности, прозрачной цитатности, наивной интертекстуальности» [Фокин 2005: 179]. Цитаты, как правило, раскрываются ссылкой автора в тексте примечаний или комментария.

Активно в своем творчестве Римма Ханинова использует и явление «паратекстуальности» (Н. А. Фатеева), или отношение текста к заглавию, эпиграфу, послесловию. В этом плане можно выделить цитаты-заглавия, содержащие в себе как бы программу всего литературного произведения и ключ к его пониманию. Заимствованные заглавные формулы, конденсирующие художественный потенциал стоящего за ними текста, служат для акцентирования в новом контексте содержательного смысла произведения. К примеру, название поэмы «Час речи» отсылает к стихотворению Иосифа Бродского «Часть речи», содержащему как раздумья онтологического характера, так и мысль о силе и противовесе поэтического слова смерти и забвению («...И мысль - парадокс сомнений всему свой смысл придает...» [Ханинова, Ничипоров 2005: 69]). Эту мысль автор выделяет уже в эпиграфе своего произведения строчках того же стихотворения Бродского: «...От всего человека вам остается часть речи. Часть речи вообще. Часть речи» [Ханинова, Ничипоров 2005: 58]. По мнению В. В. Колчанова, в поэме 
«есть аллюзии, контаминации разного рода (эпитафия «Младенцу» А. Пушкина, космическая лирика Ф. Тютчева, метафизическая (библейская) лирика И. Бродского) в национальных космологических координатах эпоса «Джангар», экзотического с точки зрения европейца» [Колчанов 2003: 4].

Стихотворения калмыцкого поэта стали явлением большой поэзии. Это результат кропотливой работы самой Р. Ханиновой. И не просто как поэта, а как поэта-филолога, что многое определяет в ее творчестве. Петрарка и Сенека, Гюго и Байрон, Пушкин и Цветаева, Блок и Есенин, Ахматова и Мандельштам, Бродский и Пастернак с их широтой и глубиной осмысления жизни, правдивым и тонким проникновением в духовный мир человека глубоко постигнуты калмыцким поэтом.

Важным для нашего исследования является мнение А. А. Фокина: «Римма Ханинова ощущает себя лидером калмыцкой русскоязычной поэзии, и каждое ее стихотворение - своеобразный завет, призыв осмыслить ход времени, сообразуясь с вековой традицией поэзии и философии, национальной культуры и религии. Ее поэзию можно охарактеризовать как откровения, фиксирующие состояния и познания. С одной стороны, она открыта гуманитарным познаниям западного мира и русской литературы, а с другой - идеям духовной независимости и самоценности личности буддистской культуры» [Фокин 2005: 180].

Помимо европейской и восточной культур родная калмыцкая литература, национальная художественная традиция становятся неиссякаемым источником творчества и преобразовательной деятельности художника слова. В творчестве Р. Ханиновой явственно ощущается влияние культуры калмыцкого народа. Особое значение при этом приобретают категории индивидуального менталитета автора. Образы, созданные поэтом, как система ключевых символов миропонимания, являются совокупностью тех отдельных специфических, символично конкретизированных черт менталитета, которые отличает тот или другой субъект культуры от других. Ведущими в лирике автора выступают традиционные для 
калмыцкой национальной культуры образы - степь, полынь, конь и т.д. Сопоставление их семантики, как и в творчестве русскоязычного калмыцкого поэта Д. Насунова, убедительно демонстрирует как явную этническую принадлежность Ханиновой, ее национальную идентичность, так и оригинальность индивидуального стиля поэта.

Художественное видение поэта демонстрирует собой яркий пример интеллектуального художественно-философского освоения мира. В этом своем качестве поэзия Ханиновой интересна и оригинальна, и в этом ее отличительная особенность. Эта линия направлена на способность поэта обобщать, отталкиваясь от реального факта. Ищущая мысль поэта находит ответы на вопросы о неуничтожимых, надвременных ценностях бытия, размышляет над непостижимыми загадками человеческого существования. Ее поэзия во многом онтологична.

Качество осмысления автором затронутых в творчестве тем свидетельствует, что Р. Ханинова - поэт высокоинтеллектуальный. Это значит, что как художник она идет и путем обращения к приметам национального видения мира, и путем эстетического проникновения в историософию, традиции мировой культуры, что свидетельствует о большой роли Ханиновой в движении и расцвете калмыцкой культуры в целом. 


\section{Заключение}

Современная русскоязычная поэзия - значительное явление в литературном процессе республики.

Калмыкия как многонациональный регион в настоящее время развивается в режиме двуязычия, что, естественно, само по себе влияет на литературный процесс, позволяет реализоваться творческому потенциалу этнических авторов вне зависимости от того, какой язык ими избран.

Для всестороннего понимания и осмысления калмыцкого художественного русскоязычия нами выявлены наиболее значимые этапы его развития. Выделенные периоды в истории русскоязычной литературы, а именно 1920-1930-е гг., конец 1960-х - 1980-е гг. и 1990-2000-е гг., обусловлены общественным развитием и эволюцией эстетических идеалов калмыцкого этноса. По сути, выделенные периоды - зеркальная проекция «поворотов» в социально-историческом процессе калмыцкого национального сообщества. Таким образом, формирование художественного русскоязычия носило не случайный характер, а было обусловлено общественно-историческими процессами.

Так, в 1920-1930-е гг. литература была особенно «озабочена» проблемами утверждения новых приоритетов, новой идеологии, связанных непосредственно с процессами как историческими, так и духовного развития личности. Развиваясь в этнической среде, вся калмыцкая национальная литература формировалась в русле социалистического реализма, главная цель которого заключалась в том, чтобы метод стал «способом образного мышления» [Борев 2002: 403]. Эстетика социалистического реализма обосновывала и закрепляла в литературе важные категории народности, историзма, социалистическую концепцию мира и человека. Выбор языка был продиктован адресацией к российскому читателю, подспудным желанием рассказать о жизни, быте калмыцкого народа тем, кто об этом не знал, и поэтому, разумеется, писателям необходим был русский язык. Связь с рус- 
ской культурой определяла духовную жизнь нации и развитие калмыцко-русского двуязычия. В целом русско-калмыцкие литературные связи реализовались в 20-30-е гг. прошлого столетия на разных уровнях, для которых были характерны обращение к русской классике, непосредственные творческие контакты писателей, обращение к одним и тем же прототипам, переводческая работа. Все эти формы литературных связей обусловили выход калмыцкой литературы к всероссийской читательской аудитории. Авторы вполне осознанно пришли к пониманию возможностей «диалога национальных культур» в рамках русского языка и способов отражения «инокультуры» в эстетическом поле русской литературы. Все эти обстоятельства в совокупности и обусловили характер художественного русскоязычного творчества представителей первого поколения калмыцких писателей, в частности А. Амур-Санана, С. Балыкова.

Основной причиной, благодаря которой художественное русскоязычие формировалось в 1970-1980-е гг., стала предшествовавшая этому периоду политика репрессий в отношении калмыков наряду балкарцами, чеченцами, ингушами, немцами, карачаевцами. Нарушение естественной языковой среды, связанной с депортацией калмыков (1943-1957 гг.), насильственная ломка сознания, лишение естественной возможности общения на родном языке вследствие целенаправленного дисперсного расселения народа небольшими группами и, как результат, активное освоение калмыками русского языка, послужило одной из основных причин формирования калмыцкого художественного русскоязычия. Писатели этого периода знали свою культуру, одинаково хорошо владели двумя языками (за исключением Д. Насунова), однако создавали свои произведения преимущественно на русском языке. Русскоязычный характер творчества калмыцких авторов не был отрицанием национальной литературы, ее русификацией, он отражал синтез разных традиций. Произведения таких авторов национальны, поскольку отражают проблемы жизни калмыцкого народа, его ментальность и опираются на его культурное наследие. 
В настоящей работе проведен анализ национально-культурного пространства художественного творчества калмыцких русскоязычных поэтов, выявление категорий, посредством которых моделируется их литературная идентичность, национальная картина мира. Расширение исследовательского поля при этом происходит через ориентацию на традиционное мировоззрение, являющееся стержнем духовной культуры этноса.

Проделанный анализ художественных произведений показывает, что современная русскоязычная поэзия Калмыкии содержит целый ряд элементов национальной идентификации. Богатство этнокультурной «концептосферы», национальное своеобразие калмыцкой русскоязычной поэзии реализуется с помощью этнокультурных элементов, архетипов национальной культуры, системы духовно-ценностных ориентиров, подразумевающих общность ментальных структур и признаков национальной культуры, которая входит в эту поэзию как неотъемлемая часть духовного богатства народа. Сопоставление их семантики в творчестве представленных авторов убедительно демонстрирует как явную этническую принадлежность, так и оригинальность индивидуального стиля. Образ мира, воссоздаваемый мастерами слова как система ключевых символов миропонимания, является совокупностью тех отдельных специфических, символично конкретизированных черт менталитета, которые отличают тот или иной субъект культуры от других. Поэзия авторов в этом смысле опирается и на прочный фундамент истинно художественной традиции: опыт предшествующих поколений, новаторские искания, органичное восприятие традиций духовной культуры своего народа в условиях современности, обращение к различным традициям русской и мировой литературы.

Наиболее важным представляется вывод, сделанный нами в ходе исследования, о том, что при выявлении национальной идентичности поэтов главным является не только тематический материал, изобразительно-выразительные средства, через которые, как отмечает Э. В. Лубинецкий, просматриваются мировидение, 
самосознание, психологические особенности этноса. Важно обратить внимание на то, какое преломление получают символические образы архетипического характера в творчестве художников. При этом важным является сам дух, общий принцип стилистического повествования, особое видение мира, разворачивающееся в пространстве национального мироощущения автора, его собственное состояние души. Вот что пишет об этом Ш. А. Мазанаев: «Умение писать о каком-либо народе не делает художника представителем этого народа. Писатель осмысливает описываемое через свое национальное мироощущение, его психология как бы фильтрует материал, который он выносит на суд читателя...» [Мазанаев 1997: 24]. В этом контексте внимание должно быть направлено, прежде всего, на нравственно-философскую концепцию и видение автора, «на эстетическое содержание текста, его сюжетную функцию, идею, стилистику изложения, отраженные изнутри» [Гутов 2007: 125]. Нам близка точка зрения К. К. Султанова, который, рассматривая актуальную проблему национальной специфики, говорит не столько о художественном своеобразии литературы, сколько о «локализации этнически преломленного самобытного мира».

Как мы уже отмечали, в творчестве русскоязычных поэтов присутствует множество специфических особенностей, обусловленных ситуацией пограничья. Калмыцких поэтов, пишущих не на родном языке, но в русле калмыцкой культурной традиции, можно отнести к представителям двух культур. Так, в отношении поэтов Д. Насунова и Р. Ханиновой можно говорить о бикультурности творческий личности. Русский язык для поэтов является, по сути, родным языком, на котором в их сознании свободно образуется стройная система ассоциаций и семантических связей. При этом он позволяет создавать глубоко национальные художественные произведения, отражающие не только историю и образ жизни калмыцкого народа, но и его ментальность, его видение мира. Язык в этом случае является «не только средством коммуникации, это и действительность мысли, ключ к национальному опыту, инструмент его познания...» [Гусейнов 1988: 397]. Мышление калмыц- 
ких русскоязычных поэтов питается, прежде всего, национальным сознанием, интуитивно обращающимся к области национального мира, — «кладовой творческой памяти русскоязычного писателя, где хранятся самобытные национальные понятия, представления о предметах, вещах и явлениях, формирующие и питающие специфику национальной образности» [Васильева 1991: 61].

В этом плане в 1970-е гг. настоящим открытием для русскоязычной поэзии Калмыкии стало творчество Д. Насунова. В поэзии калмыцкого русскоязычного художника слова, мировоззрение которого сформировалось вдали от родины, национальное начало воплотилось не только на «внешнем» уровне, что проявляется обычно в насыщенности реалиями степного быта, описании родных пейзажей, культурно-этнографических традиций, обычаев и т.д. Несмотря на то, что Насунов социализировался в русскоязычной среде и писал свои произведения на русском языке, он сохранил главное - связь с традиционным народным миропониманием, которая давала ему опору в понимании изначальной разумности мира, его целесообразности и присутствия в нем смысла.

Как отмечают исследователи, Д. Насунов внес в калмыцкую поэзию новые интонации и мироощущение, которые стали бесспорным опровержением мнения о невозможности выразить национальный характер и менталитет на языке другого народа. В этом смысле его творчество стало первой и серьезной заявкой в калмыцкой литературе о возможности существования национальной поэзии не на калмыцком языке. В ходе анализа этнокультурного пространства произведений поэта было установлено, что этническую идентичность автора выражают не только изобразительно-выразительные средства, атрибутика, национальный колорит его произведений. Поэтическое слово Джангра Насунова рождалось в корневой системе народного мировоззрения и мировосприятия, особый внутренний смысл его определен ментальностью, унаследованной от предков. Он был и остается истинно народным поэтом, развивающим в своем творчестве ценностные качества своей культуры. 
Одной из определяющих черт русскоязычной поэзии Калмыкии в 1990-2000-х гг. и в настоящее время является ее элитарность, интеллектуальность, ориентация на эрудированного читателя, теснейшая связь художнического начала с началом философским. Особенно ярко данная черта проявляется в поэзии Р. Ханиновой. От лирика Насунова ее отличает именно философичность. Р. Ханинову можно с полным основанием назвать поэтом-мыслителем, поэтом-философом, по-своему продолжающим традиции философского направления калмыцкой поэзии ХХ в., представленного, прежде всего, художественным наследием Д. Кугультинова. Практически каждое ее стихотворение насыщено ассоциативными связями, культурными реалиями, метафорами и требует от читателя определенной интеллектуальной подготовки, то есть передает то, что можно назвать умными чувствами. Именно поэтому критики, характеризируя поэзию Р. Ханиновой, дают ей определение как «ищущая, экспериментальная», «расширяющая кругозор и дающая пищу для работы ума» [Пюрвеев 1998: 3].

Особенность творчества этого автора, очарование ее поэтического стиля проявляется также в необычном и органичном сочетании европейской и восточной литературных и культурных традиций. Такой синтез делает ее поэзию одновременно и традиционной, и новаторской. Так, мифологическое наследие, культурфилософские парадигмы Востока, с их мудростью, изысканностью и утонченностью формы высказывания («По мотивам буддийских притч», «По мотивам японских сказок», «По мотивам японских преданий», «Восточные мотивы» и др.) соседствуют в ее стихотворениях с европейскими поэтическими канонами и обертонами (рондо, стансы и др.). Обращение к буддийской аксиологии скрепляется символическими библейскими мотивами, знанием мифологического наследия разных народов (поэмы «Формула судьбы», «Древние метаморфозы» и др.). Приобщение к мировой и русской классике (Сенека, Петрарка, В. Гюго, Д. Байрон, А. Пушкин, Ф. Тютчев, Б. Пастернак, М. Цветаева, А. Блок, И. Бродский и др.) связано со следованием традициям калмыцкой народной лирики, с творчеством предшественников. 
Диалог - еще одно важное свойство художественного мира Р. Ханиновой, отличающее ее от Д. Насунова и других калмыцких русскоязычных поэтов. Русская и мировая литературные традиции присутствуют в ее поэзии на уровне сюжетно-композиционных сближений, скрещения, контаминации текстов, зеркального отражения словесных выражений, то есть явных или скрытых цитат, эпиграфов, реминисценций, философских аллюзий, сознательных стилизаций, вариаций и других форм интертекстуальности. При этом интертекст никогда не является для нее буквальным повтором оригинального текста. В своем творчестве автор всегда «соблюдает преемственность поколений» [Бурыкин 2005: 134], «демонстрирует осознание, принятие и воплощение основного закона поэзии: всякий поэтический текст есть память о поэтических произведениях, созданных до него...» [Фокин 2005: 179].

Круг авторов, которые становятся полем, центром интертекстуального «излучения», широк. Это, в первую очередь, отец поэт М. Хонинов. Р. Ханинова прямо апеллирует к его стихам, разворачивая, как отмечают исследователи, заданные им темы, идеи и образы, творчески развивая их в своих стихотворениях, поэмах, вплоть до книг-диалогов: «Час речи», «Стану красным тюльпаном». Это также диалог «со всей евразийской цивилизацией» (циклы «Аксиомы», «Древние метаморфозы» и др.), с предшествующей поэтической традицией (циклы, посвященные Пастернаку, Бродскому, и многие другие отдельные произведения), диалог с Востоком («В тени Конфуция», «Буддийский пантеон»), диалоги поэта и литературоведа (книга «На перекрестках Софии и Веры») и т. д. При этом организующим началом всего перечисленного является евразийское мышление.

В целом, возможности интенсивного развития калмыцкой русскоязычной поэзии заложены во взаимосвязи ее традиционных основ и новаторских исканий. В результате расширяется тематика стихотворных произведений, складывается тенденция к расширению жанрового диапазона лирики на основе литературных форм, сформированных экстравертной природой европейского художественного мышления. 
Большой вклад в развитие жанрового разнообразия калмыцкой русскоязычной поэзии внесла Р. Ханинова, проложив дорогу новым для нее литературным жанрам и формам: афористические четверостишия, рондо, стансы, басни, притчи, стихотворение-разговор, стихотворение-диалог, пародия, стихотворные циклы, прозопоэзия, пьесы, книга-диалог и т.д., которые не встречаются, например, в творчестве Д. Насунова и В. Лиджиевой.

Современная русскоязычная поэзия Калмыкии по проблемнотематическим, стилевым направлениям, общему жанровому уровню развивается в одном русле со всей многонациональной российской литературой. Для нее характерны разноплановая онтологическая проблематика: передача сложного соотношения разума и чувства в человеческой природе, раздумья о бренности и смысле жизни, о существовании вечных, неуничтожимых ценностях человеческого бытия, контрапункт земного и вечного. Активно осваивая традиции инонационального опыта, современная калмыцкая русскоязычная поэзия ведет неустанный поиск новых творческих возможностей и идей для обогащения форм и содержания калмыцкой поэзии.

Помимо новаторства, интеллектуализации, повышенного интереса к философскому осмыслению действительности, нравственно-эстетической проблематике, освоению актуальных элементов поэтики, современную калмыцкую русскоязычную поэзию характеризует глубокая преемственная связь с устным народным творчеством. При этом, если для творчества Д. Насунова характерна органичная связь именно с калмыцким фольклором, то в поэзии Р. Ханиновой проявляется осмысление мифов и легенд народов мира, при этом работа поэта над фольклорным материалом многотемна. Она органично сочетается с детской темой (цикл сказок «По мотивам сказок народов мира»), с трансформацией буддийских притч (поэтический цикл «Наследство» 1994), с интересом к культурному, мифологическому наследию мусульманского Востока (поэма «Формула судьбы» (2001), написанная по мотивам сказки «Игра в шахматы»), с осмыслением «всей евразийской 
цивилизации на протяжении ее многовековой истории» [Бурыкин 2005: 110] («Древние метаморфозы»), а также с использованием «микрофолькорных произведений» (У. Б. Долгат). Умелое использование различных форм из арсенала устной поэзии не только обусловливает поэтическое своеобразие, но и помогает глубже раскрыть художественный образ, усилить смысловое значение произведения, служит сюжетообразующим фактором и достаточной опорой философского содержания авторского замысла.

Благодаря системе знаний и ценностной определенности, национальная художественная традиция становится неиссякаемым источником творчества и преобразовательной деятельности художников слова. Усвоенный авторами духовный строй мифа и обряда, народных сказок, пословиц и т.д. сохраняется в творчестве поэтов, при этом их внимание обращается на содержательную сторону традиции. Это выражается в том, что поэты «перечитывают» и «переосмысляют» фольклорное наследие. Наблюдается тяготение к переплавке традиционных фольклорных поэтических жанров в литературные жанровые формы. При этом, перерабатывая фольклорный материал, авторы отбирают только то, что помогает им глубже раскрыть художественный образ, усилить смысловое значение произведения в соответствии со своими идейнохудожественными задачами, индивидуальными творческими целями. Обращаясь к фольклорным источникам, калмыцкие русскоязычные поэты обогащают их современными идеями, переносят в рамки литературных жанров, - словом, дают им новую жизнь в литературе. В результате появились литературные сказки, поэмы-сказки и т. д. В современной поэзии закономерно появляется форма афористического двустишия, четверостишия, в которых сохраняется след скрытой дидактики, что лишний раз подтверждает мысль об устойчивости традиционного восприятия жизни и широких возможностях эстетики и философии, художественных форм и образов устного народного творчества.

К концу XX в. наряду с осмыслением новых тенденций, модернистских новаций в калмыцкой русскоязычной поэзии возник 
интерес к традиционной религии, к непреходящим ценностям буддийской философии, что было подстегнуто происходящим в Калмыкии процессом возрождения национальной культуры, ревитализацией буддийских институтов. Кроме того, поэты стали более глубоко размышлять о сути мирозданья, о назначении человека на Земле, о нравах и взаимоотношениях между людьми, о взаимозависимости всего сущего, всех явлений в мире. В поисках верного ответа на поставленные вопросы поэт Р. Ханинова обращается к тем чертам традиционной культуры, которые связаны с «буддийским культурным комплексом» [Четырова 2002: 67], нашедшим свое проявление в мировоззрении, нравственности, поведении, менталитете калмыков, ориентирующим их «на сотрудничество, взаимопонимание, терпимость с другими народами» [Сенглеева 2002: 54]. Поэзия стала как бы пристальней вглядываться в существо национальной традиции, что связано в некоторой степени с поисками утраченных духовных ценностей. И поскольку творческая индивидуальность теперь сама становится творцом собственного художественного мира, мы имеем возможность видеть становление эстетического и философского мироощущения современных поэтов, которые обращаются к культурному наследию через историю, проживая и переживая ее как свою.

Потребность восстановления целостности исторической памяти, поиски новых путей в изображении времени выводят калмыцкую поэзию к мировоззренческим основам, пониманию природы человека, что возвращает ей коренные свойства культуры. Объектом поэзии становится открытое сознание человека. С этой точки зрения закономерно возникновение нового жанра - философской поэмы, созданной на основе сказки. Творческое переосмысление эпического или сказочного материала обогащает палитру национальной поэзии, поднимает ее на новый художественный уровень.

В целом возможности интенсивного развития калмыцкой русскоязычной поэзии заложены во взаимосвязи ее традиционных основ и новаторских исканий. В результате расширяется тематика стихотворных произведений, складывается тенденция к рас- 
ширению жанрового диапазона лирики на основе литературных форм, сформированных экстравертной природой европейского художественного мышления.

Таким образом, в настоящей работе показано, что современная русскоязычная поэзия Калмыкии продолжает традиции калмыцкого фольклора, традиции калмыцкой, русской и мировой литературы. Об этой тенденции говорит Э. Лубинецкий: «Именно фольклорно-литературно-культурный сплав в сочетании с восточной ментальностью, национальным складом мышления сформировал структуру художественного мышления калмыцких русскоязычных поэтов... постигающих посредством него новые формы осмысления и обобщения действительности» [Лубинецкий 2007: 164]. Сейчас в русскоязычной поэзии Калмыкии, равно как, например, и в литературе Бурятии, проблема национальной идентичности, «не сводится к дилемме «мы - они»». Выделяется «такое имманентное качество идентичности, как интегративность, предполагающее внутреннюю множественность и диалог идентичностей», о котором пишет бурятский литературовед Е. Е. Балданмаксарова [Балданмаксарова 2013: 45]. В калмыцкой русскоязычной поэзии в последние годы заметна и всевозрастающая масштабность обращения к художественному наследию как Запада, так и Востока, что ясно проявляется в духовно-художественных исканиях поэта Р. Ханиновой.

В нашем исследовании определилось и еще одно существенное обстоятельство - проблема русификации калмыцкой русскоязычной поэзии, которая может расцениваться двухпланово. С одной стороны, это давний процесс, и он в определенной степени закономерен. С другой, неимение твердой национальной почвы у авторов все же несколько усложняет проблему национального возрождения, столь актуальную сегодня как для Республики Калмыкии, так и для современной России в целом. В силу многих исторических причин и обстоятельств настоящего времени в национальное самосознание могут проникать идеи, нарушающие преемственность традиций, что отрицательно скажется на картине 
литературного развития Калмыкии и отнюдь не стимулирует тенденцию к сохранению природы этнической идентификации.

В настоящее время русскоязычная поэзия Калмыкии представлена небольшим числом авторов. Тем не менее русскоязычная литература все же активно развивается: она пишется, издается, читается, расширяет свои возможности. Русскоязычная поэзия представляет собой неповторимый, по-своему самобытный ареал в калмыцкой литературе. Она становится в разряд нового образования, которое происходит на стыке двух культур (без ущерба для одной из них). Русский язык как основа творчества авторов позволяет расширить их читательскую аудиторию, что в конечном счете является популяризацией калмыцкой литературы в целом.

Тема, освещенная нами, остается открытой для дальнейших разработок. Концепция личностного сознания калмыцких русскоязычных поэтов (к примеру, Д. Насунова, Р. Ханиновой) масштабна и весьма эффективна в исследовательском плане.

Исходя из всего вышесказанного, мы можем утверждать, что современная калмыцкая русскоязычная поэзия Калмыкии представляет собой только складывающуюся эстетическую систему, однако ее идейно-художественный опыт все же свидетельствует о своей перспективности, жизнеспособности и плодотворности. 


\section{Список использованной литературы}

I

Абакарова О. М. Современная русскоязычная проза Кабардино-Балкарии: поэтика и жанров: автореф. дис. ... канд. филол. наук: 10.01.02. Кабард.-Балкар. гос. ун-т им. Х. М. Бербекова. Нальчик, 2005. 20 c.

Аверинцев С. С. Символ // Литературная энциклопедия терминов и понятий. М.: НПК «Интелвак», 2003. С. 976-978.

Аверинцев С. С. Филология // Краткая литературная энциклопедия. Т. 7. М.: Наука, 1972. С. 25-49.

Айтаев В. Д. Всадник, скачущий на коне // Теегин герл $=$ Свет в степи. 1994. № 6. С. 18-20.

Айтаев В. Д. Открытие мира // Комсомолец Калмыкии. 1991. 5 апреля. № 39 (5665). С. 3.

Айтаев В. Д. Памяти поэта // Элистинские новости. 1994. 25 марта. № 12 (205). С. 12.

Айтаев В. Д. Хочу, чтоб вы не ведали печали... // Утро Калмыкии. 2000. 19 мая. № 20. С. 7.

Айтаев В. Д. Через тяжкий перевал // Комсомолец Калмыкии. 1990. 7 ноября. № 130 (5603). С. 3.

Акопова А. А. Образы-символы Армении в русской поэзии XX века. Ереван: Асотик, 2001. 72 с.

Алексеева П. Э. О людях и времени. Элиста: КИГИ РАН, 2010. $176 \mathrm{c}$.

Алексеева П. Э. Вдали от родины: о писателе С. Балыкове // Теегин герл. 1995. № 8. С. 75-90.

Алексеева П. Э. Санджи Балыков - яркий представитель национального зарубежья // Тееегин герл = Свет в степи. 2006. № 1. С. $65-67$.

Алиева С. У. Возрождение национальных традиций // История национальных литератур. Перечитывая и переосмысливая. Вып. 1. М.: Наследие, 1995. С. 157-168. 
Алиева С. У. Поэзия репрессированных народов 30-50-х годов XX века // История национальных литератур. Перечитывая и переосмысливая. Вып. II. М.: Наследие, 1996. 288 с.

Ананьева С. В. Судьба и голос художника на изломе эпох (на материале творчества немецких и корейских писателей Казахстана) // Международные ломидзевские чтения. Изучение литератур и фольклора народов России и СНГ: Теория. История. Проблемы современного развития: Мат-лы Междунар. науч.практ. конф. (г. Москва, 28-30 ноября 2005 г.). М.: ИМЛИ РАН, 2008. C. 271-284.

Андреев Н. Среди книг и журналов: [о кн. Д. Насунова «Голоса расстояний»] / Н. Андреев // Дон. 1972. №6. С. 181-182.

Андреева В. «Час речи» - это диалог времен: [интервью с Р. Ханиновой о совместной с отцом книге] // Хальмг үнн=Калм. правда. 2002. Ноха сарин 26 (4 сент.). № 166. С. 4.

Анкранов В. Не говорите плохо о полыни // Элистинская панорама. 2005. 24 марта. № 47. С. 14.

Араева Н. «День влюбленных» - новый поэтический сборник»: [О кн. «День влюбленных»] // Изв. Калмыкии. 1998. 17 янв. № 10. С. 10.

Арутюнова Н. Д. Введение // Логический анализ языка. Ментальные действия. М.: Наука, 1993. С. 3-6.

Архипелаг Риммы Ханиновой: Детство, творчество, любовь: [Интервью с поэтом Р. М. Ханиновой / Вела А. Малякина] // Ханинова Р., Ничипоров И. На перекрестках Софии и Веры...: Стихи, поэмы, эссе. Элиста, 2005. С. 3-7.

Архипелаг Риммы Ханиновой: Детство, творчество, любовь: [Интервью с поэтом, канд. филолог. наук Р. М. Ханиновой / Вела А. Малякина] // Изв. Калмыкии. 2005. 24 марта. № 53. С. 6.

Асмолова Е. «Неслыханная простота» притчи Риммы Ханиновой: [О цикле «Древние метаморфозы» из новой книги «На перекрестках Софии и Веры»] // Хальмг үнн = Калм. правда. 2005. Хөн сарин 18 (26 мая). № 89-90. С. 15. 
Атанасова Р. Концепт «дом» в калмыцкой поэзии // Феномен личности Д. Кугультинова поэта, философа и гражданина: Мат-лы Междунар. науч.-практ. конф., посвящ. 85-летию Д. Кугультинова. (г. Элиста, 18-19 апреля 2007 г.). Элиста: Изд-во Калм. ун-та, 2007. C. $147-149$.

Атанасова Р. Депортация в творчестве Риммы Ханиновой // Восстановление национальной государственности репрессированных народов России и перспективы их развития на современном этапе: Мат-лы. Всерос. науч-практ. конф., посвящ. 50-летию восстановления национальной государственности репрессированных народов России (г. Элиста, 12-13 янв. 2007 г.). Элиста: Изд-во КалмГУ, 2006. С. $155-159$.

Атанасова Р. Концепт «душа» в поэтическом мире Риммы Ханиновой (книга «Взлететь над мира суетой») // Русский язык в полиэтнической среде: проблемы и перспективы: Мат-лы Междунар. научн.-практ. конф. (г. Элиста, 29-30 ноября 2007 г.). Элиста: Изд-во Калм. гос. ун-та, 2007. С. 133.

Ауэзов М. М. Времен связующая нить. Литературно-критические этюды. Алма-Ата: Жазушы, 1972. 136 с.

Ауэзов М. М. Проблемы национального своеобразия современной казахской литературы: автореф. дис. ... канд. филол. наук. М., 1969. 14 c.

Бабкинова Л. В. Мифопоэтика современной бурятской поэзии. Иркутск: Изд-во Иркут. гос. ун-та, 2009. 125 с.

Багликов В. М. Мне не хватало запаха полыни // Теегин герл = Свет в степи. 2008. № 5. С. 108-109.

Багомедов Р. Р. Тенденции развития современной даргинской поэзии: жанрово-стилевые, композиционно-строфические и ритмико-интонационные новации: Дис. ... канд. филол. наук. Махачкала: Дагестан. гос. ун-т, 1998. 25 с.

Бадмаев А. В. «И удержать на высоте полет души неутоленной...»: [О кн. «Взлететь над мира суетой»] // Изв. Калмыкии. 1994. 15 июня. № 102. С. 2. 
Бадмаев А. В. Калмыцкая дореволюционная литература. Элиста: Калм. кн. изд-во, 1975. 167 с.

Бадмаев А. В. Лунный свет. Элиста: Калм. кн. изд-во, 2003. 477 с.

Бадмаев В. Н. Национальная идентичность в поликультурном пространстве Юга России». Элиста: Изд-во КалмГу, 2012. 80 с.

Базанов В. Г. С родного берега: о поэзии Николая Клюева. Л.: Наука, 1990. 242 с.

Базанов В. Г. Сергей Есенин и крестьянская Россия. Л.: Сов. писатель, 1982. 304 с.

Бакаева Э. П. Добуддийские верования. Элиста: АПП «Джангар», 2003. 358 c.

Бакаева Э. П. Сакральные коды культуры калмыков. Элиста: ИКИАТ, 2009. 159 с.

Баков Х. И. Национальное своеобразие и творческая индивидуальность в адыгской поэзии. М.: «Меотий», 1994. 253 с.

Балагова-Кандур Л. Х. Литературная диаспора адыгов. Проблемы этнодуховной идентичности // Литературное зарубежье. Лица. Книги. Проблемы. М.: ИМЛИ, 2007. Вып. 4. С. 183-204.

Балакаев А. Г. Вы знаете, каким он парнем был... (К 50-летию Д. Насунова) // Известия Калмыкии. 1992. 1 января. С. 3.

Балакаев А. Г. Воин и поэт: [о М. Хонинове, в частности, о несправедливом исключении из ряда КПСС партсобранием СП Калмыкии в окт. 1979 г.] // Изв. Калмыкии. 1991. 5 нояб. № 45. С. 6.

Балданмаксарова Е. Е. «Кавьядарша» Дандина как основа развития теории поэзии монгольских народов: Мат-лы Междунар. конгр. востоковедов ICANAS XXXVII (г. Москва, 16-21 августа 2004). М.: Ин-т. Востоковед. РАН, 2004. Т. 2. С. 741-744.

Балданмаксарова Е. Е. Бурятская поэзия XX века: истоки, поэтика жанров. Москва: МГУ: 2002. 252 с. (Дополн. переизд. Улан-Удэ: БГУ, 2005).

Балданмаксарова Е. Е. Культурно-исторические основы зарождения литературы монгольских народов (XIII - нач. XX вв.). Улан-Удэ: Бэлиг, 2011. 236 с. 
Балданмаксарова Е. Е. Монгольская литература XIII-XIV вв. Улан-Удэ: Изд-во Бурят. ун-та, 2001. 104 с.

Балданмаксарова Е. Е. Художественная символика образа коня в словесном искусстве монгольских народов // Altaica XI. Сборник статей и материалов. М.: Ин-т. Востоковед. РАН, 2006. C. 8-9.

Балданмаксарова Е. Е. Этнокультурная идентичность в современной бурятской литературе и межкультурный диалог: к постановке проблемы // Исторический опыт взаимодействия народов и цивилизаций: к 350-летию добровольного вхождения Бурятии в состав Российского государства: Мат-лы Междунар. науч.-практ. конф. (г. Улан-Удэ, 5-9 июля 2010). В 2-х ч. Улан-Удэ: Изд-во ГУП ИД «Буряад үнэн», 2011. Ч. 1. С. 47-55.

Барабаш Ю. Я. Вопросы поэтики и эстетики. Изд. 3-е. М.: Наука, 1978. $384 \mathrm{c}$.

Барабаш Ю. Я. «Анти- и пост-» Гоголь в литературном сознании украинского зарубежья // Вопросы литературы. 2006. № 2. C. $165-201$

Барабаш Ю. Я. Вступительные заметки // Литературное зарубежье: проблема национальной идентичности. Вып. І. М.: Наследие, 2000. С. 3-6.

Барабаш Ю. Я. О языковой дихотомии у Гоголя // Нация. Личность. Литература. М.: Наследие, 1999. Вып. 1. С. 11-23.

Баранова Е. В. Основные тенденции развития мордовской лирики на современном этапе (1980-90-е годы): Дис. ... канд. филол. наук. Саранск, 2000. 187 с.

Басаев Д. Э. Семь звезд. Калмыцкие легенды и предания. Элиста: Калм. кн. изд-во, 2004. 416 с.

Батырева С. Г. Образная память предков. Живопись Гаря Рокчинского во времени и пространстве калмыцкой традиционной культуры. Элиста: АПП «Джангар», 2003. 304 с.

Бахтин М. М. Вопросы литературы и эстетики. Исследования разных лет. М.: Худож. лит., 1979. 504 с. 
Бахтин М. М. Эстетика словесного творчества. М.: Искусство, 1979. 412 c.

Белоус Л. В., Бикоева М. Т., Мурадова Т. А. Осетинская русскоязычная литература. ХХІ век. Владикавказ: СОГУ, 2009. 92 с.

Бембеев Т. О. Полку литераторов прибыло. Заметки с семинара молодых писателей // Элстин зәңгс = Элист. новости. 1991. 7 дек. C. 3 .

Бембеев Т. О. С заботой о молодых: [В частности о поэзии Р. Ханиновой] // Теегин герл = Свет в степи. 1992. № 2. С. 3-4.

Бембеев Т. О. Он был настоящим поэтом: [о поэте Д. Насунове] // Утро Калмыкии. 2000. 3 октября. С. 8.

Берзин А. А. Общий обзор буддийских практик. СПб.: Нартанг, 1993. $100 \mathrm{c}$.

Берзин А. А. Тибетский буддизм. История и перспективы развития. М.: Традиц. медицина, 1992. 32 с.

Бессарабова Н. А талант мой, ребята, от бога... // Советская Калмыкия сегодня. 1994. 29 марта. № 3. С. 4.

Бигуаа В. А Билингвизм в национальной литературе // Международные ломидзевские чтения. Изучение литератур и фольклора народов России и СНГ: Теория. История. Проблемы современного развития: Мат-лы Междунар. науч.-практ. конф. (г. Москва, 28-30 ноября 2005). М.: ИМЛИ РАН, 2008. С. 271-284.

Биткеев Н. Ц. Калмыцкий героический эпос «Джангар». Проблемы типологии национальных версий. Элиста: Калм. кн. изд-во, 1990. $155 \mathrm{c}$.

Бичеев Б. А. Дети Неба - Синие Волки. Мифолого-религиозные основы формирования этнического сознания калмыков. Элиста: КалмГУ, 2005. 200 с.

Бичеев Б. А. Этнообразующие доминанты духовной культуры западных монголов (ойратов). Элиста: КалмГУ, 2003. 204 с.

Большакова А. Ю. Теория архетипа на рубеже // Вопросы филологии. 2003. № 1. С. 44-54.

Борджанова Т. Г. Магическая поэзия калмыков: Исследование и материалы. Элиста: Калм. кн. изд-во, 1999. 182 с. 
Борджанова Т. Г. [О книге М. Хонинова и Р. Ханиновой «Час речи»] // Хальмг үнн. 2002. Ноха сарин 26 (4 сент.). № 166. С. 4.

Борев Ю. Б. Эстетика. М.: «Высш. шк.», 2002. 511 с.

Борев Ю. Б. Эстетика. Теория литературы: Энциклопедический словарь терминов. М.: ООО «Издательство Астрель; ООО «Изд-во ACT», 2003. $575 \mathrm{c}$.

Боровинская Т. В. Русскоязычная поэзия Кабардино-Балкарии конца XX - начала XXI века: тенденции развития, многообразие жанров и стилей, контекст: автореф. дис. ... канд. филол. наук: 10.01.02. Нальчик: Кабард.-Балкар. гос. ун-т им. Х. М. Бербекова, $2011.21 \mathrm{c}$.

Брагинский И. С. Проблемы востоковедения: Актуальные вопросы восточного литературоведения. М.: Наука, 1974. 494 с.

Бугаев Н. И. Национальное своеобразие поэтического творчества: на примере якутской поэзии: Дис. ... канд. филол. наук: 10.01.02. Якутск: Якут. гос. ун-т им. М. К. Аммосова. 2000. 146 с.

Буддизм и литература. М.: ИМЛИ РАН, 2003. 432 с.

Буддизм: Словарь. Под общ. ред. Жуковской Н. Л. и др. М.: Республика, 1992. 288 с.

Бурыкин А. А. «Не баранину и не конину вам...»: [В интервью Р. Ханиновой «Передать - значит сохранить...»] // Элист. панорама. 2005. 7 апр. № 56. С. 14.

Бурыкин А. А. Грани таланта, грани времени: [О кн. М. В. Хонинова, Р. М. Ханиновой «Час речи»] // Теегин герл = Свет в степи. 2002. № 8. С. 107-109.

Бурыкин А. А. Древние метаморфозы Риммы Ханиновой // Изв. Калмыкии. 2003. 9 сент. № 210-211. С. 8.

Бурыкин А. А. На перекрестках стиха: Новые издания: [O новой кн. Р. Ханиновой и И. Ничипорова «На перекрестках Софии и Веры...»] // Элист. панорама. 2005. 18 окт. № 189. С. 3.

Бурыкин А. А. Обретение идентичности: О поэзии Риммы Ханиновой // Ханинова Р. М., Ничипоров И. Б. «На перекрестках Софии и Веры...»: Стихи, поэмы, эссе. Элиста: АПП «Джангар», 2005. C. $10-43$. 
Бурыкин А. А. Ханинова по-английски: От переводчика // Калм. ун-т. 2004. 28 авг. № 9. С. 5.

Бурыкин А. А. Диалоги в пространстве и времени: [к выходу кн. М. Хонинова и Р. Ханиновой «Стану красным тюльпаном»] // Известия Калмыкии. 2010. 16 апр. № 65-66. С. 14.

Бурыкин А. А. Диалоги в пространстве и времени. Новые реальности калмыцкой литературы // Хонинов М. В., Ханинова Р. М. Стану красным тюльпаном: стихи, поэмы, переводы, повесть. Элиста, 2010. С. 710-714.

Бурыкин А. А. Диалог поэтов на фоне времени // Изв. Калмыкии. 2009. 13 марта. № 42-43. С. 13.

Бурыкин А. А. Древние метаморфозы риммы Ханиновой [в частности, о преемственности поколений Хониновых, о кн. «Час речи»] // Изв. Калмыкии. 2003. 9 сент. № 210-211. С. 8.

Бурыкин А. А. Знаковые штрихи к калмыцкой литературе // Вестник Калмыцкого университета. 2010. № 9. С. 75-77.

Буханцов Н. С. Современная поэзия народов СССР: (O характере лирического героя). Кн. для учащихся. М.: Просвещение, $1983.96 \mathrm{c}$

Буханцов Н. С. О характере лирического героя // Современная поэзия народов СССР. Кн. для учащихся. М.: Просвещение, 1983. C. $77-78$.

Бюрчиев Б. Из звука слова «люблю»: [О кн. Р. Ханиновой и И. Ничипорова «На перекрестках Софии и Веры...»] // Изв. Калмыкии. 2005. 13 июля. № 128. С. 5.

В редакцию «РП» поступили.... [Аннотация книги «Час речи»] // Рос. писатель. 2003. № 16 (67) сент. С. 16.

В частности о поэзии Р. Ханиновой // Джамбинова Р. А. Литература Калмыкии: Проблемы развития. Элиста, 2003. С. 22, 125, 210, 212-213.

Васильев В. Поэтическая звезда Джангра Насунова // Элистинская панорама. 2007. 26 июня. № 105. С.2.

Васильев В. Час речи: [О презентации книги «Час речи» в Нац. б-ке им. Амур-Санана] // Вечер. Элиста. 2003. 7 марта. № 17-18. С. 3. 
Васильева В. Чайка, подстреленная на взлете // Элистинская панорама. 2007. 21 июня. №. 102. С. 7.

Васильева Д. Е. Национальное и общечеловеческое в якутской литературе. Якутск: МГП «Полиграфист», 1995. 181 с.

Васильева Р. П. Художественный билингвизм в мордовской литературе и его национально-стилевая природа: автореф. дис. ... канд. филол. н.: 10.01.02. Саранск, 1991. 20 с.

Вежбицкая А. Язык. Культура. Познание. М.: Рус. словари, 1996. $411 \mathrm{c}$.

Веретенников В. Преемственность поколений: [О презентации книги «Час речи» в Нац. б-ке им. Амур-Санана] // Элстин зәңгс = Элист. новости. 2003. 18 марта. № 17. С. 3.

Веселовский А. Н. Историческая поэтика. М.: Высш. шк., 1989. 406 с.

Виноградов В. В. Наука о языке художественной литературы и ее задачи. М.: АН СССР, 1958. 51 с.

Волков Г. Н. Великие этнопедагогические ценности эпоса «Джангар» [О книге «Час речи»] // Этнопедагогический ежегодник. Чебоксары, 2005. Вып. 1. С. 107-113. [Арх. поэта].

Волков Г. Н. Этнопедагогический диалог дочери с отцом // Гегәрлт. 2005. № 5, 6. С. 10-12.

Волков Г. Н. Этнопедагогический диалог дочери с отцом: Размышления о книге «Час речи» Михаила Хонинова и Риммы Ханиновой: [В сокращении] // Ханинова Р. «Другой судьбы не надо...». Жизнь и творчество Михаила Хонинова: Автобиография. Интервью. Воспоминания современников. Очерки. Статьи. Элиста, 2005. С. 254-255.

Волков Г. Н. Этнопедагогический диалог дочери с отцом: Размышления о книге «Час речи» Михаила Хонинова и Риммы Ханиновой // Хальмг үнн = Калм. правда. 2005. Моһа сарин 21 (31 марта). № 53-54. С. 15.

Воробьева С. Ю. [О поэзии Р. Ханиновой] // Элист. панорама. 2005. 7 апр. № 56. С. 14. 
Воробьева С. Ю. Поэтический мир Риммы Ханиновой // Калм. ун-т. 2005. 10 июня. № 8. С. 11.

Воронов Е. Римма Ханинова «Творю с ощущением «за того парня» // Изв. Калмыкии. 2002. 17 дек. № 261. С. 6.

Восточная поэтика: Тексты. Исследования. Комментарии. М.: Издат. фирма Вост. лит. РАН, 1996. 342 с.

Вы знаете, каким он парнем был... К 50-летию Джангра Насунова (круглый стол: А. Г. Балакаев, О. Л. Манджиев, А. Д. Далаев, Б. Н. Манджиев) // Известия Калмыкии. 1992. 1 января. № 1. С. 4.

Выходцев П. С. Есенин в современной поэзии // Есенин и современность. М.: Современник, 1975. С. 11-34.

Вяткина К. В. Культ коня у монгольских народов // Советская этнография. 1968. № 6. С. 117-122.

Газизова А. А. Русская тема в «Маобитской тетради» М. Джалиля // Диалог культур: русско-татарские связи: Мат-лы науч.практ. семинара Всерос. конф. «Славянская культура: истоки, традиции, взаимодействие». М.; Ярославль: Ремдер, 2005. С. 83-93.

Гамзатов Г. Г. Дагестанский феномен возрождения. XVIIIХІХ вв. Махачкала: ДНЦ РАН, 2000. 324 с.

Гамзатов Г. Г. Двадцатый век как эпоха национальных литератур и региональных общностей // Международные ломидзевские чтения. Изучение литератур и фольклора народов России и СНГ: Теория. История. Проблемы современного развития: Мат-лы Междунар. науч.-практ. конф. (г. Москва, 28-30 ноября 2005 г.). М.: ИМЛИ РАН, 2008. С. 10-21.

Гармаева С. И. Взаимодействие национального и интернационального в бурятской литературе // Новые тенденции в современной литературе Бурятии. Улан-Удэ: Бурят. кн. изд-во, 1988. C. $3-21$.

Гаспаров М. Л. Стих // Литературная энциклопедия терминов и понятий. М.: НПК «Интелвак», 2003. С. 10-34.

Гачев Г. Д. Национальные образы мира. Космо-Психо-Логос. М.: Прогресс-Культура, 1995. 480 с. 
Гачев Г. Д. Чингиз Айтматов и мировая литература / предисл. Е. Озмителя. Фрунзе: Кыргызстан, 1982. 284 с.

Гиршман М. М. Ритм художественной прозы. М.: Сов. писатель, 1982.367 с.

Глинин Г. Г. Путь исканий: Современная литература Калмыкии. Проблемы и характеристики. Элиста: Калм. кн. изд-во, 1987. $95 \mathrm{c}$.

Голубева Е. В. Калмыцкие культурные концепты. Элиста: Изд-во КалмГУ. 2009. 157 с.

Григорьев В. П. Речь художественная // Литературный энциклопедический словарь / под ред. В. Кожевникова и П. А. Николаева. М.: Сов. энцикл., 1987. С. 322-323.

Григорьева Р. Прерванный полет // Известия Калмыкии. 2007. 30 июня. № 120. С. 5.

Гудкова С. П. Современная русскоязычная поэзия Мордовии в контексте мордовской литературы (70-90-е гг.): автореф. дис. ... канд. филол. наук: 10.01.02. Саранск: Мордов. гос. ун-т им. Н. П. Огарева, 1998. 15 c.

Гусейнов Ч. Г. Русскость нерусских // Вопросы литературы, 2006. № 2. С. 223-261.

Гусейнов Ч. Г. Этот живой феномен. Советская многонациональная литература вчера и сегодня: Монография. М.: Сов. писатель, 1988. 432 с.

Гусейнов Ч. Г. О двуязычии в художественном творчестве: история, теория, практика // Вопросы литературы. 1987. № 9. C. $79-112$.

Гутов А. М. Константы в культурном пространстве: публицистика, фольклор, литература. Нальчик: Эльбрус, 2011. 214 с.

Гюльмагомедов А. Терра-инкогнита // Дагестанская правда. 28 апр. 1995. С. 3.

Далаев А. Д. На белый свет всегда глядел влюблено. К 65-летию со дня рождения Д. Насунова // Теегин герл = Свет в степи. 2007. № 4. С. 77-80. 
Далаев А. Д. А я самой России слава... // Степная мозаика. 2012. 21 июля. № 28. С. 8.

Далаев А. Д. Воспоминания друга. Первая встреча // Советская Калмыкия сегодня. 2007. 4 июня. № 2 (191). С. 2.

Далаев А. Д. Звенящая лира Д. Насунова // Хальмг үнн. 2007. 26 июня. № 125. С. 4.

Далаев А. Д. Слово о друге // Утро Калмыкии. 2000. 23 июня. № 25. C. 7.

Далай-лама XIV. Буддизм Тибета. Москва Рига: НартангУгунс, 1991. 103 с.

Дампилова Л. С. «Образ мира в слове явленный» в монголоязычной поэзии // Актуальные проблемы бурятской филологии: Мат-лы регион. науч.-конф., посвящ. 20-летию кафедры бурятской филологии ИГУ (г. Иркутск, 23 апреля 2010 г.): Иркутск: издво Иркут. гос. ун-та, 2010. С. 202-208.

Дампилова Л. С. Восточные художественные традиции в современной бурятской поэзии: Дис. ... канд. филол. наук. Улан-Удэ, 1997. $135 \mathrm{c}$.

Дампилова Л. С. Символика кочевого пространства в поэзии Баира Дугарова. Улан-Удэ: Изд-во БНЦ СО РАН, 2005. 162 с.

Данчинова М. Д. Художественная картина мира в литературе Бурятии 1960-1990-х гг. (пространственно-временная архитектоника): Дис. ... канд. филол. наук: 10.01.02. Улан-Удэ, 2000. 138 с.

Дарваев П. А. «Этот дивный мир переживаний...»: [О кн. «Зимний дождь»] // Элстин зәңгс = Элист. новости. 1993. 14-20 авг. № 33 .

Дарваев П. А. «Я помню сердцем бабье лето...»: [О поэтической династии Хониновых] // Молодежь Калмыкии. 1993. 3 июня. № 24. C. 3.

Дарвин М. Н. Художественная циклизация лирики // Теория литературы: в 4 тт. Т. 3: Роды и жанры: (основные проблемы в историческом освещении) / под ред. Ю. Б. Борева. М.: ИМЛИ PAH, 2003. C. 467-515. 
Демьяненко В. Хотел бы превратиться я в звезду (Статья из книги «Край родной земля яшалтинская»)... // Теегин герл. 2012. № 3. С. 36-37.

Денисова М. Памяти поэта: [о поэте Д. Насунове] // ЭЖ Калм. 2000. 24 марта. № 12. С. 8.

Джамбинова Р. А. Литература в нашей судьбе: [Интервью с д-ром филол. наук Р. А. Джамбиновой / Беседовала В. Шуграева]: [В частности о поколении литераторов 1980-1990-х гг.] // Хальмг үнн = Калм. правда. 2002. Үкр сарин 1 (5 нояб.) № 209. С. 3.

Джамбинова Р. А. Поэзия - исповедь души // Теегин герл. 1999. № 8. C. 99-100.

Джамбинова Р. А. Проблема обновления национальных художественных традиций: [В частности полемика с Р Ханиновой о романе М. Хонинова «Помнишь, земля смоленская»] // Вестник: (Сб. науч. тр.) / КИГИ РАН; Отв. ред. Н. Г. Очирова. Элиста, 2002. Вып. 17. С. 181-182.

Джамбинова Р. А. Взлететь на Геликон: [O кн. «День влюбленных»] // Элстин зәңгс = Элист. новости. 1998. 21-27 марта. № 13. С. 13.

Джамбинова Р. А. Кто станет символом поэта?: [В частности о поэзии Р. Ханиновой] // Теегин герл = Свет в степи. 1992. № 2. C. 36 .

Джамбинова Р. А. Поэзия Калмыкии (некоторые наблюдения): [В частности о новом литературном поколении] // Хальмг үнн $=$ Калм. правда. 2003. Хулһн сарин 1 (27 сент.), № 200-201. С. 10.

Джамбинова Р. А. В потоке безвременья (некоторые аспекты национального литературного зарубежья) // Проблемы современного калмыковедения (сборник научных трудов). Элиста: АПП «Джангар», 2001. С. 38-40.

Джамбинова Р. А. Дыхание современности. Элиста: Калм. кн. изд-во, $1982.112 \mathrm{c}$.

Джамбинова Р. А. История калмыцкой литературы XX в.: состояние и проблемы // Научная мысль Кавказа. 2006. № 3. Спецвыпуск. С. 127-132. 
Джамбинова Р. А. Калмыцкая литература XX века. В трех книгах. Кн. первая. Калмыцкая художественная проза XX века [Отв. ред. А. М. Казиева]. Элиста: НПП «Джангар», 2006. 272 с.

Джамбинова Р. А. Калмыцкая художественная проза XX века. В трех книгах. Кн. первая. Отв. ред. А. М. Казиева. Элиста: НПП «Джангар», 2006. 272 c.

Джамбинова Р. А. Литература Калмыкии. Проблемы развития. Элиста: АПП «Джангар», 2003. 240 с.

Джамбинова Р. А. Литература Калмыкии: каноны буддизма // Буддийская культура и мировая цивилизация на пороге III тысячелетия: Мат-лы Междунар. науч.-практ. конф. (г. Элиста, 19-21 сентября 2000 г.). СПб.; Элиста, 2000. С. 107-109.

Джамбинова Р. А. Писатель и время. Элиста: АПП «Джангар», 1996. 204 c.

Джамбинова Р. А. Писатель Санжи Балыков в оценке профессора А. Борманджинова // Проблемы современного калмыковедения (сборник научных трудов). Элиста: АПП «Джангар», 2001. C. 54-66.

Джамбинова Р. А. Роль национальных традиций в становлении советской калмыцкой поэзии (20-30-х годов). // В сб.: Национальные традиции и генезис социалистического реализма в калмыцкой литературе. Элиста: Калм. кн. изд-во, 1977. С. 78-81.

Джамбинова Р. А. Постижение подвига (калмыцкая литература периода Великой Отечественной войны 1941-1945 гг.): [в частности, о поэзии М. Хонинова] // Герои войны — герои литературы (Писатели-фронтовики о Великой Отечественной войне). Элиста: НПП Джангар», 2010. С. 812.

Джамбинова Р. А. Национальные художественные традиции в прозе Калмыкии XX века: автореф. дис. ... д-ра филол. наук: 10.01.02. Махачкала: Дагестан. науч. центр Рос. акад. наук. Ин-та. языка, лит. и иск-ва им. Гамзата Цадасы, 2000. 48 с.

Джамбинова Р. А. Возвращение [Текст]: о Санжи Балыкове // Теегин герл. 1991. № 6. С. 117-121. 
Джамбинова Р. А. Шаги духовного примирения: к 100-летию писателя Санжи Балыкова // Теегин герл. 1993. № 5. С. 91-104.

Джангар: Калмыцкий народный эпос / пер. с калм. С. И. Липкина, вступ. статья Б. К. Пашкова. Элиста: Калм. кн. изд-во, 1989. $365 \mathrm{c}$.

Джангр Насунов: [кр. биогр.] // Белая дорога: [сб. стихов] / Г. Кукарека, Д. Насунов, Л. Петрова, А. Сусеев, Д. Шанаев; ред. О. Манджиев. Элиста: Калм. кн. изд-во, 1976. С. 25.

Джрбашян Э. М. Четыре вершины. М.: Сов. писатель, 1990. $317 \mathrm{c}$.

Джусойты Н. О национальном языке и национальном стиле // Дружба народов. 1957. № 12. С. 172-181.

Джушхинова К. А. Национальный компонент в речевом поведении билингва и культура речи (на материале русской речи калмыков): [В частности о поэзии Р. Ханиновой. С. 49-51] // Русская речь в инонациональном окружении: межвуз. сб. науч. тр. / под ред. Т. С. Есеновой и др. Элиста: Изд-во Калм. ун-та. 2003. Вып. І. C. $45-55$.

Джушхинова К. А. Роль национально-культурного фактора в речевом поведении билингва (на примере Калмыкии): [Творчество Р. М. Ханиновой] // Материальные и духовные основы калмыцкой государственности в составе России (К 360-летию со дня рождения хана Аюки): Мат-лы Междунар. науч.-практ. конф. (г. Элиста, 2025 мая 2002). В 2 ч. Элиста, 2002. Ч. 1. С. 57.

Дишкант Е. В. Национально-художественное своеобразие творчества русскоязычных якутских поэтов (1970-1990 гг.): автореф. дис. ... канд. филол. наук: 10.01.02. Якутск: Якут. гос. ун-т им. М. К. Аммосова, 2004. 16 с.

Дмитровская М. А. Макрокосм и микрокосм в художественном мире А. Платонова: Учебное пособие. Калининград: Изд-во КГУ, 1998. $80 \mathrm{c}$.

Дмитриева В. Час судьбы и встречи: (к выходу кн. М. Хонинова и Р. Ханиновой «Час речи»): [интервью с Р. Ханиновой] // Элстин зәңгс = Элистинские новости. 2002. 6 сент. № 67. С. 9. 
Дмитриева С. Стихи как жизнь не терпит фальши... (о поэзии Муняновой Б. Б.) // Новая неделя. 2001. 23 марта. № 12. С. 15.

Долгат У. Б. О роли фольклорных и этнографических элементов в литературе // Национальное и интернациональное в литературе, фольклоре и языке. Кишинев: «Штиинца», 1971. C. 186-204.

Долгат У. Б. Этнопоэтика в русской прозе 20-х - 90-х гг. ХХ века (Экскурсы). М.: ИМЛИ РАН, 2004. 212 с.

Дорджиев В. «Всадник, скачущий впереди»: [о поэзии Д. Насунова] // Теегин герл = Свет в степи. 1994. № 6. С. 18-20.

Дорджиева Д. Б. Обретая судьбу: о творчестве В. Лиджиевой // Теегин герл = Свет в степи. 1980. № 2. С. 69-76.

Дорджиева Д. Б. ...И я пришел ушедшему на смену // Теегин герл = Свет в степи. 2012. № 3. С. 21-24.

Дробышев Ю. И. Экологические аспекты традиционной культуры монгольских народов // Человек и Природа в духовной культуре Востока. М.: ИВ РАН: крафт+, 2004. С. 488-503.

«Другой судьбы не надо...»: Жизнь и творчество Михаила Хонинова: Автобиография. Интервью. Воспоминания современников. Очерки. Статьи / Римма Ханинова; Отв. ред. Г. М. Борликов. Элиста: Изд-во Калм. ун-та, 2005. 56 с.

Дугаржапова Т. М. Бурятская поэзия: проблемы поэтики и стиля: автореф. дис. ... д-ра филол. наук: 10.01.02. Уфа: Башкир. гос. ун-т, 2004. 73 с.

Дугаров Д. Э. Исторические корни белого шаманства на материале обряда фольклора бурят. М.: Наука, 1991. 300 с.

Душан У. Д. Обычаи и обряды дореволюционной Калмыкии // Этнографический сборник. Вып. 1. Элиста: Калмиздат, 1976. C. 19-20.

Дякиева Р. Б. Талисман Риммы Ханиновой // Комсомолец Калмыкии. 2003. 15-21 янв. № 1. С. 3.

Евгеньева Л. Я с каждым годом ближе, ближе... // Элстин зәңгс = Элистинские новости. 2003. 18 июля. № 48. С. 3. 
Евтушенко Е. А. «Разглядели вы, Римма Ханинова...»; «Не с кастетом и не с наганом...» Посвящение Р. Ханиновой // Изв. Калмыкии. 2005. 24 марта. № 53. С. 6.

Евтушенко Е. «Разглядели Вы, Римма Ханинова...»; «Не с кастетом...» [Стихи] // Изв. Калмыкии. 2005. 24 марта. № 53. С. 6.

Есенин С. А. Собр. соч. в 2 томах. Т. 1. М.: Сов. Россия, Современник, $1990.384 \mathrm{c}$.

Есенова Т. С. Русский язык и в Калмыкии: социокультурные портреты и лингвокультурные типажи: Монография. Элиста: Издво Калм. гос. ун-та, 2007. 192 с.

Есенова Т. С. Русский язык в Калмыкии. Элиста: Изд-во Калм. гос. ун-та, 2003. 208 c.

Есенова Т. С., Чульчаева Г. М., Херминова Ц. Ч. Образ родины в полиэтнической среде: проблемы и перспективы: Мат-лы Междунар. науч.-практ. конф. (г. Элиста, 29-30 ноября 2007 г.). Элиста: Изд-во Калм. гос. ун-та, 2007. С. 62-65.

Есин А. Б. Принципы и приемы анализа литературного произведения. М.: Флинта: Наука, 2004. 248 с.

Еше Пагчог. Буддизм: Шаг первый. Элиста: АПП «Джангар», 2002. $96 \mathrm{c}$.

Жигачева М. В. Эволюция жанра баллады в русской поэзии 60-80-х годов XX века: автореф. дис. ... канд. филол. наук: 10.01.02. М.: МГУ им. М. В. Ломоносова, 1994. 16 с.

Жирмунский В. М. Введение в литературоведение: Курс лекций. СПб.: Изд-во СПб. ун-та, 1996. 438 с.

Жирмунский В. М. К вопросу об эпитете // Теория литературы. Поэтика. Стилистика. Л.: Наука, Ленинград. отд-е, 1977. С. 355-361.

Жирмунский В. М. Сравнительное литературоведение. Восток и Запад. Л.: «Наука» Ленинград. отд-е, 1979. 493 с.

Жолковский А. К., Щеглов Ю. К. К понятиям тема и поэтический мир // Труды по знаковым системам. 1975. Вып. 7. C. $143-147$.

Буддизм. Словарь / под общ. ред. Жуковской Н. Л, Корнева В. И. М.: Республика, 1992. 288 с. 
Жуковская Н. Л. Категории и символика традиционной культуры монголов. М.: Наука, 1988. 194 с.

Жуковская Н. Л. Кочевники Монголии: Культура. Традиции. 121. Символика: Учебное пособие. М.: Вост. лит., 2002. 247 с.

Зайцев В. А. О новых тенденциях в русской поэзии 1980-1990х годов // Вестник МГУ. Сер. 9. Филология. 1996. № 4. С. 9-21.

Зайцев В. А. Русская советская поэзия 60-х-70-х годов (жанрово-стилевые искания и тенденции): автореф. дис. ... д-ра филол. наук: 10.01.02. М.: МГУ им. М. В. Ломоносова, 1983. 37 с.

Захарова Г. Буду стихами молиться / Интервью с поэтессой В. Лиджиевой // Хальмг үнн. 2002. № 35. 20 февраля. С. 1-3.

Звегинцев В. А. Теоретико-методологические предпосылки Сепира-Уорфа // Новое в лингвистике. М.: Изд-во лит. на иностр. яз., 1960. Вып. І. С. 111-134.

Золотцев С. Я мужеству учился. Реценз. обзор на сборник Д. Насунова «Тамариск» // Литературное обозрение. 1983. № 3. С. $57-58$.

Зулумян Б. С. Гевонд Алишан. Вдали от родины, с родиной в душе // Литературное зарубежье. Лица. Книги. Проблемы. М.: ИМЛИ РАН, 2007. ВЫп. 4. С. 112-128.

Иванов Г. Жил-был поэт. Размышления вслух // Теегин герл = Свет в степи. 2012. № 3. С. 32-36.

Иллюстрированная энциклопедия символов. М.: ООО «Издво Астрель»; ООО «Изд-во АСТ», 2003.723 с.

Иллюстрированная энциклопедия символов. М.: ООО «Издво АCT», 2003. $723 \mathrm{c}$.

Ильин И. И. Интертекстуальность // Современное литературоведение (страны Западной Европы и США): концепции, школы, термины. Энциклопедический справочник. М.: Интрада, 1999. C. 204-208.

Ильин М. Не выходя из боя: заметки о военной теме в творчестве М. Хонинова // Элстин зәңгс=Элистинские новости. 2003. 5 сент. № 62. С. 8-9. 
Ильина Н. Г. Поэтический мир современной чувашской лирики: автореф. дис. ... канд. филол. наук: 10.01.02. Чебоксары: Чуваш. гос. ун-т им. И. Н. Ульянова, 2002. 17 с.

Ипполитова Н. В. Женский почерк: [О кн. «День влюбленных»] // Хальмг үнн. 1998. Моһа сарин 13 (11 марта). № 44. С. 3.

Ирвисова С. Подобно метеору // Элистинская панорама. 2011. 9 июля. № 98. С. 5.

История калмыцкой литературы. В 2 тт. Элиста: Калм. кн. издво, 1980. 445 с.

История советской многонациональной литературы. В 6 тт. Т. 5. М.: Наука, 1974. 839 с.

Кабаченко Е. Т. Антон Амур-Санан. Жизнь и творчество. Элиста: Калм. кн. изд-во, 1967. 127 с.

Кадырова К. А. Перевод как средство взаимовлияния и взаимообогащения национальных литератур // Этнонациональная ментальность в художественной литературе: Мат-лы Всерос. науч.практ. конф. (г. Ставрополь, 22-24 сентября 1999 г.). Ставрополь: Изд-во СГУ, 1999. С. 224-227.

Калмыцкая народная поэзия: Сб. науч. тр. / отв. ред. Биткеев Н. Ц. Элиста: КНИИФЭ, 1984. 165 с.

Калмыцкие молитвы / сост. Н. Д. Дандырова. Элиста: Калм. кн. изд-во, 1999. 235 с.

Карасик В. И. Культурные доминанты в языке // Языковой круг: личность, концепты, дискурс. Волгоград: Перемена, 2002. C. 166-205.

Качмазова Н. Г. Современная русскоязычная проза народов Севера: автореф. дис. ... канд. филол. наук: 10.01.02. Екатеринбург: Урал. гос. пед. ун-т, 1995. 26 с.

Квятковский А. П. Поэтический словарь. М.: Сов. энцикл., 1966. $546 \mathrm{c.}$

Килганова 3. И. В атаку поднимался первым: [О творчестве поэта М. Хонинова, в частности о переводе Р. Ханиновой поэмы М. Хонинова «Сказание о калмычке»] // Элстин зәңгс = Элист. новости. 1999. 26 дек. 1 янв. №1. С. 5. 
Килганова 3. И. Поиски и находки: Очерки творчества современных писателей Калмыкии. Элиста: Калм. кн. изд-во, 1977. 78 с.

Килганова 3. И. Поэт Джангар Насунов // Калмыцкий университет. 2007. 13 июля. № 9-10.

Килганова 3. И. Поэтический дебют (О сборнике Джангара Насунова) // Поиски и находки. Очерки творчества современных писателей Калмыкии. Элиста. 1977. С. 69-73.

Килганова 3. И. Поэты и время. Статьи о калмыцкой поэзии. Элиста: Калм. кн. изд-во, 1971. 124 с.

Кичиков А. Ш. Героический эпос «Джангар»: Сравнительнотипологическое исследование памятника. М.: Издат. фирма «Вост. лит.», 1997. 320 с.

Кожинов В. В. Поэзия и проза // Литературная энциклопедия терминов и понятий. М.: НПК «Интелвак», 2003. С. 778-781.

Колчанов В. Стихи её покоряют... // Хальмг үнн = Калм. правда. 2003. Така сарин 19 (17 июля). № 143-144. С. 4.

Конфуций [из Свободной энциклопедии «Википедия»] // URL: http://ra.wikipedia.org/wiki/Конфуций (дата обращения 15.01.2011).

Королев К. М. Предисловие. Мифология символа // Энциклопедия символов, знаков, эмблем. М.: Мидгард, 2005. С. 3-16.

Котвич В. Л. Калмыцкие загадки и пословицы / под ред. М. Э. Джимгиров, А. В. Бадмаев, А. Э. Тачиев. Элиста: Калм. кн. изд-во, 1972. $91 \mathrm{c.}$

Кошелева А. Л. Поэт и время. Современная поэзия Красноярского края / под ред. Р. Солнцев. В. Белкин, А. Федорова, З. Яхнин // Поэтическое слово Сибири. Проза, поэзия, фольклор. Красноярск, 1991. Вып. 3. 96 с.

Кошелева А. Л. Хакасская поэзия 1920-1990-х годов: типология и закономерности развития. Абакан: Изд-во Хакас. гос. ун-та им. Н. Ф. Катанова. 2001. 320 с.

Краткая литературная энциклопедия. М.: Сов. энцикл., 1978. T. $4.968 \mathrm{c}$. 
Кубрякова Е. С. Образы мира в сознании человека и словообразовательные категории как их составляющие // Изв. РАН СЛЯ. 2006. Т. 65. № 2. С. 3-14.

Кугультинов Д. И. Пути и судьбы современной поэмы // Литературное обозрение. 1974. № 10. С. 41-57.

Кугультинов Д. Н Вечная память // Высланы... Оставлены навечно. В 2 тт. Элиста, 1993. Т. І. С. 3-9.

Кудаева 3. Ж. Мифопоэтическая Модель адыгской словесной культуры. Нальчик: Эльбрус, 2008. 296 с.

Кузьмина Н. А. Интертекст и его роль в процессах эволюции поэтического языка. М.: Едиториал УРСС, 2004. 272 с.

Куканова В. В., Джушхинова К. А. Лексико-семантический анализ поэтического текста (на примере стихотворения Р. Ханиновой «Цветок солнца») // Сборник научных трудов молодых ученых, аспирантов и студентов Калмыцкого государственного университета. Элиста: Калм. гос. ун-т, 2004. С. 106-108.

Кукарека Г. Г. Из рода журавлиных (О творчестве В. Лиджиевой) // Теегин герл = Свет в степи. №5. 1990. С. 109.

Кукарека Г. Г. Недопетая песня // Известия Калмыкии. 2007. 22 июня. № 113-114. С. 14.

Кукарека Г. Г. Поэты Калмыкии детям: [О книжках-малышках библиотечки журнала «Баир», в том числе о книжке Р. Ханиновой «Умная мышка»] // Хальмг үнн = Калм. правда. 2002. Һаха сарин 18 (24 сент.). № 180. С. 4.

Куров Г. «На привольной полынной планете я живу...»: О творчестве В. Лиджиевой // Комсомолец Калмыкии. 1982. 5 авг. С. 4.

Кучукова 3. А. Поэзия Кайсына Кулиева в русских переводах (к проблеме передачи национального колорита): автореф. дис. ... канд. филол. наук: 10.01.02. М.: Ин-т Миров. лит. им. А. М. Горького, 1992. 21 с.

Лаврентьев Н. Посвящение Р. Ханиновой // Теегин герл = Свет в степи. 1995. № 1. С. 125. [Содерж.: «Хожу и думаю о вас...»; «Ты с друзьями, а я потерян...»]. 
Лагунова О. А. Феномен творчества русскоязычных писателей ненцев и хантов последней трети XX века (Е. Айпин, Ю. Вэлла, А. Неркаги): автореф. дис. ... д-ра филол. наук: 10.01.02: СПб.: Ин-т народов Севера Рос. гос. пед. ун-та им. А. И. Герцена, 2008. 18 с.

Ланцынова М. В литературной гостиной: [О презентации книги «Зимний дождь» в Нац. б-ке им. А. М. Амур-Санана] // Изв. Калмыкии. 1993. 27 нояб. № 219. С. 2.

Ланцынова М. Нет, не был лишним он! // Комсомолец Калмыкии. 1990. 30 октября. № 126. С. 3.

Лейдерман Н. Л. Русскоязычная литература перекресток культур // Русская литература XX-XXI веков: направления и течения. Екатеринбург, 2005. С. 50.

Липец Р. С. Образы батыра и его коня в тюрко-монгольском эпосе. М.: Наука, 1984. 263 с.

Литература (Р. А. Джамбинова, А. Г. Салдусова, Р. М. Ханинова) // История Калмыкии с древнейших времен до наших дней. В 3 тт. Элиста: ГУ Издат. дом «Герел», 2009. Т. 3. С. 492-528.

Литература Калмыкии на современном этапе: проблемы идейно-художественного развития: Сб. ст. / Калм. НИИ истории, филологии и экономики / под ред. Р. А. Джамбинова. Элиста: Калм. НИИ истории, филологии и экономики, 1987. 125 с.

Литература народов России: Учебное пособие. Автор Р. 3. Хайруллин / под ред. К. М. Нартова. М.: Ин-т национал. проблем образования МО РФ, 1995. 165 с.

Литература народов Российской Федерации. Биобиблиографический справочник. М.: Знание, 1993. 126 с.

Литературная энциклопедия терминов и понятий / под ред. Николюкина А. Н. Институт научной информации по общественным наукам РАН. М.: НПК «Интелвак», 2003. 1600 с.

Лихачев Д. С. Поэтика древнерусской литературы. М.: Наука, 1979. 352 c.

Логаева А. А. Русско-калмыцкие литературные связи: автореф. дис. ... канд. филол. наук: 10.01.02. М.: МПГУ, 2006. 169 с. 
Ломидзе Г. И. На уровень новых задач // Вопросы литературы. 1977. № 10. С. 156-161.

Лосев А. Ф. Проблема символа и реалистическое искусство. М.: Искусство, 1976. 367 с.

Лубинецкий Э. В. О современной калмыцкой русскоязычной поэзии // Теегин герл = Свет в степи. Элиста. 2007. № 3. С. 121-127.

Лубинецкий Э. В. Своеобразие художественной речи в современной поэзии Калмыкии (Г. Г. Кукарека, В. Н. Лиджиева, Р. М. Ханинова): автореф. ... канд. филол. наук: 10.01.02. М.: МПГУ, 2007. 18 с.

Лурия А. Р. Язык и сознание. М.: Изд-во МГУ, 1998. 336 с.

Мазанаев Ш. А. Русскоязычная литература Дагестана: проблемы национального и интернационального взаимодействия. Махачкала: Даг. кн. изд-во, 1984. 131 с.

Майнагашева Н. С. Художественный билингвизм в хакасской литературе: к постановке вопроса: www.gramota.net/ materials/2/2013/1/29.html

Малунова Л. Звезда по имени Джангр! // Утро Калмыкии. 2002. 15-21 июня. № 22. С. 7.

Малякина А. Архипелаг Риммы Ханиновой: детство, творчество, любовь // Известия Калмыкии. 2005. 24 марта. № 53. С. 6.

Малышев А. Первая книга поэта: [о кн. Д. Насунова «Голоса расстояний»] // Сов. Калмыкия. 1971. 14 дек.

Малышева Г. Н. Очерки русской поэзии 1980-х годов. (Специфика жанров и стилей). М.: Наследие, 1996. 173 с.

Манджиев Н. Ц. «Жизнь эстафета...»: [О кн. М. В. Хонинова, Р. М. Ханиновой «Час речи»] // Теегин герл = Свет в степи. 2004. № 3. С. 107-116.

Манджиев Н. Ц. «Взлететь над мира суетой...»// Изв. Калмыкии. 1993. 11 июня. № 107. С. 2.

Манджиев Н. Ц. Путь речи...: (Приглашение к разговору) // Хальмг үнн = Калм. правда. 2003. Така сарин 19 (17 июля). № 143144. C. 4. 
Манжилеева Р. Ц. Седклин чивһц көндәж, Сана-седкл үүмүлнә // Хальмг үнн = Калм. правда. 1996. Мөрн сарин. 21 (21 марта). № 21. C. 4.

Мантатов В. В., Доржигушаева О. В. Экологическая этика и современность. Научная монография. Улан-Удэ: Бурят. кн. изд., 1997. $160 \mathrm{c}$.

Маргания Л. Б. Поэтика произведений русскоязычных писателей Абхазии и Адыгеи: автореф. дис. ... канд. филол. наук: 10.01.02. Майкоп: Адыг. гос. ун-т, 1996. 14 с.

Мелетинский Е. М. О происхождении литературно-мифологических сюжетных архетипов // Литературные архетипы и универсалии / под ред. Е. М. Мелетинского. М.: Рос. гос. гуманит. ун-т, 2001. С. 72-104.

Мелетинский Е. М. Поэтика мифа. 3-е изд., репринтное. М.: Издат. фирма «Вост. лит.» РАН, 2000. 407 с.

Минералов Ю. И. История русской литературы: 90-е годы ХХ века. М.: Гуманит. изд. центр «Владос», 2002. 224 с.

Мифологический словарь / Гл. ред. Е. М. Мелетинский. М.: Сов. энцикл, 1990. 672 с.

Михайловская Н. Г. Стиль русскоязычной литературы Севера и Дальнего Востока. М.: Наука, 1984. 160 с.

Морохоева 3. П. Личность в культурах Востока и Запада: к постановке проблемы. Новосибирск: Наука, 1994. 198 с.

Москвин В. П. Русская метафора. Волгоград: Перемена, 1997. $91 \mathrm{c}$.

Надъярных Н. С. Аксиология перечтений. М.: ИМЛИ РАН, 2008. 336 c.

Намруева Л. В. Проблема этнокультурной идентичности в условиях модернизации общества // Материальные и духовные основы калмыцкой государственности в составе России (к 360-летию со дня рождения хана Аюки): Мат-лы Междунар. науч.-практ. конф. (г. Элиста, 22-25 мая 2002 г.). В 2 ч. Ч. 2. Элиста: КалмГУ, 2002. С. 36-37. 
Намруева Л. В. Проблемы сохранения языка в контексте глобализации социокультурных трансформаций // О тенденциях взаимодействия и взаимовлияния русского и национального языков в современной России: Мат-лы Общерос. науч.-практ. конф. (г. Элиста, 19-20 ноября 2007 г.). Элиста: КИГИ РАН, 2008 г. C. 43-51.

Науменко А. Мне дорог лес и степь мне дорога: [о поэте Д. Насунове] / А. Науменко // Зори Маныча. 1998. 14 июля. № 56. C. 3 .

Науменко-Порохина А. В. Русская лирическая поэзия 19601980-х годов. Основные тенденции развития: автореф. дис. ... д-ра филол. наук: 10.01.01. Симферополь, 1998. 38 с.

Непохотный И. Память о поэте жива // Элистинские новости. 1995. 8-15 апреля. № 15. С. 12.

Николаев П. А. Введение в литературоведение. Москва: Высш. шк., 1997. 350 с.

Ничипоров И. Б. «На перекрёстках Софии и Веры...»: о новом поэтическом цикле Риммы Ханиновой // Элист. новости. 2003. 18 нояб. № 81. С. 6.; Калм. ун-т. 2003. 6 нояб. № 13. С. 7.

Ничипоров И. Б. «Час речи пробил»: философская поэма Риммы Ханиновой // Хальмг үнн = Калм. правда. 2004. Хөн сарин 21 (9 июня). № 122. С. 7.

Ничипоров И. Б. «Шахматная» поэма Риммы Ханиновой: [О поэме «Формула судьбы», созданной по мотивам сказки «Игра в шахматы»] // Изв. Калмыкии. 2004. 10 авг. № 158. С. 5.

Ничипоров И. Б. «Пастернаковский цикл» Риммы Ханиновой // Теегин герл = Свет в степи. 2005. № 4. С. 114-115.

Ничипоров И. Б. От афоризма к притче: Поэтические циклы Риммы Ханиновой «В тени Конфуция» и «Ключи разума» // Азия в Европе: Взаимодействие цивилизаций. «Язык, культура, этнос в глобализованном мире: На стыке цивилизаций и времен»: Мат-лы Междунар. конгресса (г. Элиста, 17-18 мая 2005 г.). В 2 ч. Элиста: КалмГУ, 2005. Ч. І. С. 124-132. 
Ничипоров И. Б. Эпическая традиция в современной калмыцкой поэзии: философские поэмы Риммы Ханиновой // «Джангар» в евразийском пространстве: Мат-лы Междунар. науч. конф. (Элиста, 27 сент. - 2 окт. 2004). Элиста: КалмГУ, 2004. С. 79-85.

Ничипоров И. Б. Эссе «Час речи...»: философская поэма Риммы Ханиновой // Ханинова Р. М., Ничипоров И. Б. На перекрестках Софии и Веры... / стихи, поэмы, эссе. Элиста: АПП «Джангар», 2005. C. 71-76.

Ничипоров И. Б. Диалог культур состоялся: Один из авторов о совместной работе: [О новой кн. Р. Ханиновой и И. Ничипорова «На перекрестках Софии и Веры...»] // Элистинская панорама. 2005. 18 окт. № 189. С. 3.

Ничипоров И. Б. Мифология в зеркале лирики («Древние метаморфозы» Риммы Ханиновой) // Хальмг үнн = Калм. правда. 2004. Туула сарин 8 (29 янв.). № 23-24. С. 15.

Ничипоров И. Б. Новая жизнь средневекового поэтического жанра: «Ключи разума» Риммы Ханиновой // Хальмг үнн = Калм. правда. 2004. Хулһн сарин 22 (4 нояб.). № 233-234. С. 14.

Ничипоров И. Б. От афоризма к притче: О поэтическом цикле Риммы Ханиновой «В тени Конфуция» // Элист. панорама. 2005. 15 фев. № 24. С. 7.

Нюденова Э. К. Этнокультурный аспект изучения темы «Человек в тоталитарном государстве на уроках литературы в школе: (на материале цикла стихов Риммы Ханиновой «Сибирской памяти тетрадь») // Литература в движении эпох: межвуз. сб. науч. трудов. Элиста: Изд-во Калм. ун-та, 2006. С. 161-166.

Овшинова Т. О весне и любви говорю неустанно... // Элистинская панорама. 2005. 22 марта. № 45. С. 6.

Овшинова Т. Прилетела в мир сентября... // Комсомолец Калмыкии. 1987. 3 янв. С. 4.

Ользеева С. 3. Калмыцкие обычаи и традиции. Элиста: АПП «Джангар», 2003. 256 с.

Он ушел из жизни молодым... // Интервью с 3. И. Рогожкиной. Беседовала 3. Убушиева // Российские вести в Калмыкии. 25 марта. 1995. № 12 (12). С. 18. 
Османова 3. Г. Современные аспекты литературно-художественного двуязычия // Способность к диалогу. В 2 ч. Ч. 1. М.: Наука, 1993. С. 85.

Очир-Гаряев В. У поэзии женское лицо // Теегин герл = Свет в степи. 1998. №3. С. 119.

Очир-Гаряев В. У поэзии женское лицо: [О кн. «День влюбленных»] // Теегин герл = Свет в степи. 1998. № 3. С. 117-120.

Очиров В. У. Идейно-художественное своеобразие современной калмыцкой поэмы (1960-80 гг.): автореф. дис. ... канд. филол. наук: 10.01.02. М.: Ин-т Миров. лит. им. А. М. Горького, 1990. $27 \mathrm{c}$.

Очирова Н. Г. О взаимодействии русского и калмыцкого языков на современном этапе // О тенденциях взаимодействия и взаимовлияния русского и национального языков в современной России: Мат-лы общерос. науч.-практ. конф. (г. Элиста, 19-29 ноября 2007 г.). Элиста: КИГИ РАН, 2008. 208 с.

Очиров У. Б. Герои Калмыкии // М. В. Хонинов, Р. М. Ханинова. Стану красным тюльпаном: стихи, поэмы, переводы, повесть. Элиста: НПП «Джангар», 2010. 736 с.

Очирова Э. Формула счастья Риммы Ханиновой // Элистинская панорама. 2010. 6 марта. № 49. С. 3.

Павлович Н. В. Язык образов. Парадигмы образов в русском поэтическом языке. М.: ИРЯ РАН, 1995. 491 с.

Пашкевич О. И. Проблема национального менталитета в литературе народов Якутии): автореф. дис. ... канд. филол. наук: 10.01.02. Якутск: Изд-во ЯГУ, 2002. 18 с.

Передать значит сохранить.... [Беседа с поэтом Р. М. Ханиновой / Вела В. Дмитриева] // Элист. панорама. 2005. 7 апр. № 56. C. 14 .

Песковенко О. Р. «Поэта дар есть порученье свыше...»: [О презентации кн. «Зимний дождь» в Нац. б-ке им. А. М. Амур-Санана] // Молодежь Калмыкии. 1993. 30 нояб. № 47. С. 2.

Петрова М. П. Мир поэзии Риммы Ханиновой // Теегин герл $=$ Свет в степи. 2002. № 6. С. 108-120. 
Петрова Л. И. О розах, вдохновении, стихах // Советская Калмыкия. 1993. 25 дек. С. 3.

Петрова Л. И. Он улетел за облака... // Парламентский вестник. 2009. 17 марта. № 19. С. 7.

Петрова Л. И. Птица с небес поэзии // Советская Калмыкия. 1992. 24 сент. С. 4.

Петрова М. П. Мир поэзии Риммы Ханиновой // Материальные и духовные основы калмыцкой государственности (к 360-летию со дня рождения хана Аюки): Мат-лы Междунар. науч.-практ. конф. (г. Элиста, 20-25 мая 2002 г.). В 2 ч. Элиста, 2002. Ч. 2. С. 45-47.

Петрова М. П. Мир поэзии Риммы Ханиновой // Теегин герл = Свет в степи. 2002. № 6. С. 108-120.

Подобрий А. В. К вопросу о понятиях «русскоязычная литература» и «национальная атрибуция писателя // Мировая литература в контексте культуры пограничные процессы в литературе и культуре: Мат-лы Междунар. науч.-практ. конф., посвящ. 125-летию со дня рожд. В. Каменского (г. Пермь, 17-19 апреля 2009 г.). Пермь: ПермГУ, 2009. С. 82-84.

Поканинова Е. Б. Московские встречи с Эрнстом Неизвестным: [В частности об отношении скульптора к стихотворным посвящениям, в том числе к стихотворению Р. Ханиновой] // Изв. Калмыкии. 1999. 9 июня. № 47. С. 3.

Поляков Н. Н. Антон Амур-Санан. Элиста: Калм. кн. изд-во. $1970.68 \mathrm{c}$.

Попова М. П. Основные тенденции развития современной якутской поэзии (1980-2000 гг.): автореф. дис. ... канд. филол. наук: 10.01.02. Якутск: Якут. гос. ун-т им. М. К. Аммосова, 2004. $18 \mathrm{c}$.

Постовалова В. И. Язык отражает действительность или выражает ее знаковым способом? // Роль человеческого фактора в языке: Язык и картина мира. М.: Наука, 1988. С. 8-172.

Потапов Л. П. Конь в верованиях и эпосе народов Саяно-Алтая // Фольклор и этнография. Л.: Наука, 1977. С. 164-178. 
Потебня А. А. Слово и миф. М.: Правда, 1989. 282 с.

Потебня А. А. Теоретическая поэтика. М.: Высш. шк., 1990. $344 \mathrm{c}$.

Пошатаева А. В. Литературы народов Севера: Истоки. Становление. Развитие. М: Наука, 1988. 167 с.

Поэт, увы, недолговечен. (Интервью с А. Д. Далаевым. Беседовала В. Дорджиева) // Комсомолец Калмыкии. 1990. 7 ноября. № 130 (5603). С. 3.

Поэты Калмыкии. Сборник стихов. М.: Сов. писатель, 1958. $176 \mathrm{c}$.

Пространство в традиционной культуре монгольских народов / Б. 3. Нанзатов, Д. А. Николаева, М. М. Содномпилова, О. А. Шагланова М: Издат. фирма «Вост. лит.», 2008. 341 с.

Пыхтина Ю. Г. Модель интертекстуального пространства в художественной литературе // Филологические науки. Вопросы теории и практики. Тамбов: Грамота, 2013. № 3 (21). В 2-х ч. Ч. II. С. $167-172$.

Пюрвеев В. Д. Свет любви: [О кн. «День влюбленных»] // Изв. Калмыкии. 1998. 11 марта. № 52. С. 3.

Пюрвеев В. Д. В семье братских литератур // Динамика ценностных и культурных ориентаций народов Калмыкии. Элиста: КалмГУ, 2001. С. 129-142.

Пюрвеев В. Д. Движение жизни движение литературы. Элиста: Калм. кн. изд-во, 1981. 119 с.

Пюрвеев В. Д. Традиции и творческая индивидуальность писателя // Сб. науч. тр. Элиста: КалмГУ, 2001. С. 78.

Пюрвеев Д. Б. Всадник на белой дороге: [о кн. Д. Насунова «Голоса расстояний»] // Комсомолец Калмыкии. 1971. 28 дек. С. 3.

Рамонов С. Д. «Русскоязычие» как проблема национальных литератур // Дарьял. 1996. № 1. С. 98-100.

Рогожкина 3. И. Он ушел из жизни молодым...: [в памяти Д. Насунова, интервью с сестрой поэта 3. И. Рогожкиной / беседовала 3. Убушиева] // Рос. вести в Калмыкии. 1995. 25 марта. 
Родники народной мудрости / предисл. и сост. Б. Б Оконов. Элиста: Калм. кн. изд-во, 1984. 112 с.

Роднянская И. Б. Лирический герой // Краткая литературная энциклопедия. В 9 тт. М.: Сов. энцикл., 1967. Т. 4. С. 231-214.

Роднянская И. Б. Художественное время и художественное пространство // Литературная энциклопедия терминов и понятий. М.: НПК «Интелвак», 2003. С. 1174-1177.

Розенблюм Ю. Б. В поисках волшебного амуланга. Портрет калмыцкой литературы. М.: Современник, 1976. 221 с.

Розенблюм Ю. Б. Песнь степи обновленной. О некоторых особенностях художественного мира современной калмыцкой литературы. Элиста: Калм. кн. изд-во, 1980. 114 с.

Розенблюм Ю. Б. Сквозь пламя костров: прошлое и настоящее калмыцкой литературы. Элиста: Калм. кн. изд-во, 1970. 340 с.

Рэтхэу Ю. С. Пробуждение добрых чувств // Теегин герл = Свет в степи. № 4. 1965. С. 73-78.

Саap А. Волшебный мир преображенья: [О цикле «Древние метаморфозы»] // Время Калмыкии. 2004. 26 июля. № 7. С. 3.

Савинов А. До зыбкого луча...: [О кн. «На перекрестках Софии и Веры...»] // Время Калмыкии. 2005. 6 мая. № 5 (146). С. 4.

Салдусова А. Г. Духовная основа калмыцкой литературы // О тенденциях взаимодействия и взаимовлияния русского и национального языков в современной России: Мат-лы общерос. науч.-практ. конф. (Элиста, 19-29 ноября 2007 г.). Элиста: КИГИ РAH, 2007. С. 48-49.

Салдусова А. Г. Насунов Джангар Иванович (1933-1979) // Литература народов России ХХ века. Словарь (отв. ред. Н. С. Надъярных). М.: Наука, 2005. С. 133-134.

Салдусова А. Г. Поэзия // История Калмыкии с древнейших времен до наших дней. В 3 тт. Элиста: ГУ Издат. дом «Герел», 2009. Том 3. С. 492-528.

Салдусова А. Г. Традиция как знак культуры // «Единая Калмыкия в единой России: через века в будущее»: посвященной 400-летию добровольного вхождения калмыцкого народа в состав 
Российского государства: Мат-лы Междунар. науч.-практ. конф. (г. Элиста, 13-18 сентября 2009 г.). В 2 ч. Ч. 2. Элиста: ЗАО «Джангар», 2009. С. 147-151.

Санджиев А. Б. Ради бога, прошу вас, не лезьте под кожу. // Известия Калмыкии. 1994. 18 марта. № 46. С. 4.

Санджиев А. Б. Джангру Насунову: [стихотворение] / А. Санджиев // Рос. вести в Калмыкии. 1995. 25 марта.

Сербиненко В. В. Соловьев: Запад, Восток и Россия. М.: Наука, 1994. 208 с.

Сергеева Н. М. Ум и разум // Антология концептов / под ред. В. И. Карасика, И. А. Стернина. Волгоград: Парадигма, 2005. В 2 т. T. 1. C. 295-315.

Серебряный С. Д. Комментарии // Толстой Л. Н. Круг чтения: Избранные, собранные и расположенные на каждый день Л. Толстым мысли многих писателей об истине, жизни и поведении / сост., вступ. ст. А. Н. Николюкина. М.: Политиздат, 1991. Т. 2. С. 334-338.

Сидоров В. О Джангре Насунове // Насунов Д. Тамариск: Стихи / сост. Д. Б. Пюрвеев. М.: Современник, 1982. С. 3-5.

Ситник В. М. Английские переводы лирики Риммы Ханиновой: [Ханинова по-английски] // Калм. ун-т. 2004. 28 авг. № 9. С. 5.

Ситник В. М. Встреча культур [О новых английских переводах лирики Р. Ханиновой] // Калм. ун-т. 2005. 1 июля. № 9. С. 7.

Ситник В. М. Уровни выражения противопоставленности в английских переводах лирики Риммы Ханиновой // Монголоведение в новом тысячелетии (К 170-летию организации первой кафедры монгольского языка в России): Мат-лы Междунар. науч.практ. конф. (г. Элиста, 22-26 сентября 2003 г.). Элиста: КалмГУ, 2003. С. $85-89$.

Скородумова Л. Г. Монгольский мир: язык образа. УланБатор, 2004. 323 с.

Славецкий В. И. Русская поэзия 80-90-х годов ХХ века: тенденции развития, поэтика. М.: Лит. ин-т им. А. М. Горького, 1998. 174 c. 
Современная русскоязычная поэзия Калмыкии: учеб. пособие / Калм. ун-т; коллектив авторов; отв. ред. Р. М. Ханинова. Элиста: Изд-во Калм. ун-та, 2012. 224 с.

Современный литературный процесс и литературная критика в Калмыкии: Сб. науч. тр. / под общ. ред. Р. А. Джамбиновой, В. Д. Пюрвеева, 3. Б. Улюмджиевой. Элиста: КНИИЯЛИ, 1977. $160 \mathrm{c}$.

Соломова О. Став звездой, в неведомой дали...: [стихотворение, посв. Д. Насунову] / О. Соломова; пер. с калм. В. Багликова // Теегин герл = Свет в степи. 1999. № 7. С. 84.

Степанов Ю. С. Константы: Словарь русской культуры. М.: Академ. проект, 2004. 989 с.

Степанов Ю. С., Проскурин С. Г. Константы мировой культуры. М.: Наука, 1993. 156 с.

Степин С. Н. Особенности жанровой динамики русской поэзии Мордовии 1970-90-х годов: автореф. дис. ... канд. филол. наук: 10.01.02. Саранск: Мордов. гос. пед. ин-т им. М. Е. Евсевьева, 2000. 17 c.

Стефаненко Т. Г. Этнопсихология: Учебник для вузов. М.: Аспект-Пресс, 2004. 368 с.

Сударкина X. 3. Феномен мультикультурализма в глобализирующихся обществах // Буддизм в России и на Западе: исторический опыт и реалии. Сб. статей / под ред. Хабуновой Е. Э., Бадмаевой В. Н., Улановой М. С. Элиста: НПП «Джангар», 2012. C. 101-108.

Султанов К. К. Национальная литература как система художественных ценностей. М., 1995. 187 с.

Султанов К. К. Национальное самосознание и ценностные ориентации литературы. М.: Наследие, 2001. 194 с.

Султанов К. К. От дома к миру: этнонац. идентичность в литературе и межкультурный диалог. М.: Наука, 2007. 302 с.

Султанов К. К. Поэзия северокавказской эмиграции: мотив «исторической родины» // Литературное зарубежье: проблема национальной идентичности. Вып. І. М.: Наследие, 2000. С. 46-54. 
Султанов К. К. Символика или образ «Другого» в литературе северокавказской диаспоры // Литературное зарубежье. Лица. Книги. Проблемы. М.: ИМЛИ РАН, 2007. Вып. 4. С. 4-23.

Сусеев А. И. К постановке вопроса о калмыцком стихосложении // Калмыцкая художественная литература на подъеме: Мат-лы науч.-практ. конф., посвящ. калм. художеств. лит. и фольклору. Элиста: Калмкнииздат, 1962. С. 56.

Тартаковский П. И., Каганович С. Л. Русскоязычная поэзия Узбекистана на современном этапе. Ташкент: Фан, 1991. 239 с.

Тачиева К. А. Индивидуальность манеры: [О кн. «Взлететь над мира суетой»] // Элстин зәңгс = Элист. новости. 1994. 26 фев. 4 марта. № 9. С. 9.

Творю с ощущением «за того парня»: [Интервью с поэтом Р. Ханиновой / Провела Е. Воронова] // Изв. Калмыкии. 2002. 17 дек. № 261. С. 6.

Темирханова Г. Б. Система творческих взаимосвязей и процессы жанрового преобразования национальных литератур: Лезгинская поэзия второй половины XX столетия: автореферат дис. ... д-ра филол. наук: 10.01.02. Махачкала: Дагест. пед. ун-т, 2005. $37 \mathrm{c}$.

Теория литературы. В 3 тт. Т. 3. Роды и жанры (основные проблемы в историческом освещении). М.: ИМЛИ РАН. 2003. 590 с.

Тимофеев Л. И. Основы теории литературы. М.: Просвещение, 1971. $461 \mathrm{c}$.

Томашевский Б. В. Теория литературы. Поэтика. М.: АспектПресс, 1999. 333 c.

Топоров В. Н. Модель мира // Мифы народов мира. Энциклопедия в 2-х т. М.: «Сов. энцикл.», 1988. В 2 тт. Т. 2. С.161-164.

Топоров В. Н. Пространство и текст // Текст. Семантика и культура: сборник научных работ. М.: Наука, 1983. С. 227-284.

Тхагазитов Ю. М. Духовно-культурные основы кабардинской литературы. Нальчик: Эльбрус, 1994. 248 с.

Тхагазитов Ю. М. Эволюция художественного сознания адыгов. Нальчик: Эльбрус, 1996. 251 с. 
Тынянов Ю. Н. Проблема стихотворного языка. Л.: «Academia», 1924. $138 \mathrm{c}$.

Тэн И. Философия искусства. М.: Республика, 1996. 350 с.

Убушаев В. В. Калмыки: выселение, возвращение, возрождение. 1943-1959 гг. Элиста: Санан, 1991. 96 с

Убушаева С. Прорасту тюльпанами в степи: Михаил Ванькаевич Хонинов - известный калмыцкий писатель-фронтовик, которому в январе этого года исполнилось бы 85 лет со дня его рождения // Новая жизнь = Шин Жирһл. 2004. 23 марта. № 23. C. 2 .

Урнов Д. М. Национальная специфика литературы как предмет исторической поэтики // Историческая поэтика. Итоги и перспективы изучения. М.: Наука, 1986. С. 168-187.

Успенская С. (Ханинова Р.) Из рода журавлиных / Интервью с Валентиной Лиджиевой // Теегин герл. 2009. № 4. С. 99-101.

Ушанова Г. Нернь мартдшго // Хальмг үнн = Калм. правда. 2012. 26 июня. № 108. С. 2.

Фатеева Н. А. Интертекст в мире текстов. Контрапункт интертекстуальности. М.: КомКнига, 2006. 282 с.

Философия Риммы Ханиновой: [О поэзии Р. Ханиновой] // Хальмг үнн = Калм. правда. 2003. Така сарин 19 (17 июля). № 143144. C. 4.

Фокин А. А. Диалог поэтов в многоголосье культуры: цикл Риммы Ханиновой «На перекрестках Софии и Веры...». Памяти Бродского» // Азия в Европе: Взаимодействие цивилизаций: Науч. конф. «Язык, культура, этнос в глобализованном мире: на стыке цивилизаций и времен»: Мат-лы Междунар. конгр. В 2 ч. Элиста: Изд-во КалмГу, 2005. Ч. І. С. 179-183.

Фокин А. А. Поэзия диалога Риммы Ханиновой // Современная литература Северного Кавказа: герои, сюжеты, поэтика: Мат-лы регион. науч.-практ. конф. (г. Ставрополь, 14-15 октября 2011). Ставрополь: изд-во «Графа», 2011. С. 112-116.

Фокин А. А. Этническая ментальность и проблема перевода // Этнонациональная ментальность в художественной литературе: 
Мат-лы Всерос. науч.-практ. конф. (г. Ставрополь, 22-24 сентября 1999 г.). Ставрополь: Изд-во СГУ, 1999. С. 214-224.

Фокин А. А. Заметки на полях необычной книги Риммы Ханиновой // Римма Ханинова: биобиблиогр. указ. / сост. Н. С. Нимеева; Ред. Л. П. Акиева; Нац. б-ка им. А. М. АмурСанана. Элиста, 2005. С. 10-18.

Фоменко И. В. Лирический цикл: становление жанра, поэтика. Тверь: Твер. гос. ун-т, 1992. 124 с.

Хайруллин Р. 3., Бирюкова С. К. Литература народов России. СПб.: Просвещение, 1995. 495 с.

Ханинова Р. М. В атаку поднимался первым: [о жизни и творчестве М. Хонинова] // Утро Калмыкии. 2002. 23 февраля.

Ханинова Р. М. Передать - значит сохранить... // Римма Ханинова, записала В. Дмитрева // Элистинская панорама. 2005. 7 апр. №. 56. С. 14.

Ханинова Р. М. Завет отцовский непреклонен: дерзай, будь стойким до конца! // Калм. ун-т. 2004. 6 мая. № 6. С. 3.

Ханинова Р. М. Разговор с отцом: [эссе] // Знамя Октября. 2004. 30 марта. № 26. С. 3 .

Ханинова Р. М.: [Биогр.] // Ханинова Р. М., Ничипоров И. Б. «На перекрестках Софии и Веры...»: Стихи, поэмы, эссе. Элиста: АПП «Джангар» 2005. С. 8.

Ханинова Р. М. Предисловие // Современная русскоязычная поэзия Калмыкии: учеб. пособие / Калм. ун-т; коллектив авторов; отв. ред. Р. М. Ханинова. Элиста, 2012. С. 3-4.

Ханинова Р. М. Фольклор в лирике Джангра Насунова // «Диалог культур»: национальное и инонациональное в литературе»: Мат-лы Всерос. с междунар. участием очно-заочной науч.-практ. конф. (г. Элиста, 15 апреля 2013). Элиста: Изд-во Калм. ун-та, 2013. С. 127-132.

Ханинова Р. М. Тема депортации в возвращенной литературе XX века (поэма Михаила Хонинова «Мой путь») // Историософия в русской литературе XX и XXI вв.: традиции и новый взгляд: Мат-лы ХІ Шешуковских чтений. М., 2007. С. 298-305. 
Ханинова Р. М. «Другой судьбы не надо...». Жизнь и творчество Михаила Хонинова: автобиография, интервью, воспоминания современников, очерки, статьи. Элиста: Изд-во Калм. ун-та, 2005. $256 \mathrm{c}$.

Ханинова Р. М. Лирика Давида Кугультинова и Михаила Хонинова в контексте калмыцкой поэзии XX века. Элиста: Изд-во Калм. ун-та, 2009. 143 с.

Ханинова Р. М. Предисловие к циклу «Сибирской памяти тетрадь», посвящ. М. Хонинову // Элистин зәңгс = Элистинские новости. 1993. 11-17 сент. № 37. С. 5.

Ханинова Р. М. Мне ближе вечное, не суетное...: [в частности, о своих переводах поэм М. Хонинова] // ТВ-Джангар. 2001. 13 июня. № 27. С. 4.

Ханинова Р. М. Сейчас у меня звездный час: [интервью] // Изв. Калмыкии. 1993. 14 авг. № 149. С. 3.

Ханинова Р. М. Поэзия — это ответ на дисгармонию жизни... // Элстин зәңгс = Элистинские новости. 1993. 29 мая -4 июня. № 22. C. 9.

Ханинова Р. М. От переводчика // Хонинов М. В., Ханинова Р. М. «Час речи: стихи и поэмы». Элиста, 2002. С. 212.

Ханинова Р. М. Семантика седла в поэзии Михаила Хонинова в аспекте фольклорных традиций // Проблемы монголоведных и алтаистических исследований: Мат-лы Междунар. науч.-практ. конф., посвящ. юбилею В. И. Рассадина (г. Элиста, 11-13 сент. 2009) // Элиста: Изд-во Калм. ун-та, 2009. С. 297-211.

Ханинова Р. М. Посвящение: [образ полыни в лирике М. Хонинова] // Изв. Калмыкии. 2008. 29 марта. № 57. С. 6.

Ханинова Р. М. Хочу я, вспыхнув пропылать тюльпаном ...// Изв. Калмыкии. 2008. 19 апр. № 72. С. 6.

Ханинова Р. М. Возвращение к Пенелопе // Хальмг үнн = Калм. правда. 2005. Мөрн сарин 29 (7 апреля). № 57-58. С. 14.

Ханинова Р. М. От таланта - талант! // Изв. Калмыкии. 2007. 31 октября. 2007. 31 окт. № 206. С. 4. 
Ханинова Э. М. Диалог народов в аспекте межкультурной коммуникации: Римма Ханинова Карлтон Коупланд // «Восстановление национальной государственности репрессированных народов России и перспективы их развития на современном этапе»: Мат-лы Рос. науч.-практ. конф. (г. Элиста, 12-13 янв. 2007). Элиста: Изд-во КалмГУ, 2007. С. 143-146.

Ханинова Э. М., Шовадаева С. В. Им снилась по ночам война...: Тема Великой Отечественной войны в художественном диалоге Михаила Хонинова и Риммы Ханиновой // Элист. панорама. 2005. 25 марта. № 48. С. 6.

Ханинова Э. М. Поэма Риммы Ханиновой «Солнечный Лев» в аспекте буддийских традиций воспитания // Буддийское духовенство и культура калмыцкого народа: Мат-лы межрегион. науч.практ. конф., посвящ. 405-летию со дня рождения выдающегося просветителя Зая Пандиты Намкай Джамцо. (г. Элиста, 20-21 октября 2004). Элиста: АПП «Джангар», 2004. С. 109-115.

Ханинова Э. М. Этнопедагогическое наследие Михаила Хонинова: автореф. дис. ... канд. пед. наук: [В частности о творчестве Р. М. Ханиновой]. Чебоксары: Чуваш. гос. пед. ун-т им. И Я. Яковлева, 2005. 22 с.

Ханинова Э. М. Этнопедагогическое наследие М. Хонинова в формировании нравственных ценностей // Гегәрлт. 2005. №. 1, 2. C. 113-117.

Ханинова Э. М., Шовадаева С. В. Им снилась по ночам война... Тема Великой Отечественной войны в поэтическом диалоге Михаила Хонинова и Риммы Ханиновой // Ханинова Р. «Другой судьбы не надо...». Жизнь и творчество Михаила Хонинова: Автобиография. Интервью. Воспоминания современников. Очерки. Статьи. Элиста: Изд-во КалмГУ, 2005. С. 221-226.

Ханинова Э. М. Калмыцко-чувашские пословичные параллели (на материале примечаний к книге стихов и поэм Михаила Хонинова и Риммы Ханиновой «Час речи») // Этнопедагогический ежегодник [научно-иссслед. ин-та этнопед. Чуваш. гос. ун-та им. И. Я. Яковлева]. Чебоксары, 2006. Вып. 2. С. 206-210. 
Ханинова Э. М. Мир родной речи в лирике Р. Ханиновой // Русский язык в полиэтнической среде: проблемы и перспективы: Мат-лы Междунар. науч.-практ. конф., 29-30 нояб. 2007 г. Элиста: Изд-во Калм. ун-та, 2007. С. 171-175.

Ханинова Э. М. Мотив сыновней памяти в лирике М. Хонинова // Хальмг үнн = Калм. правда. 2004. Така сарин 15 (31 июля). № 159. C. 5.

Хейчиева Г. Вечер поэзии: [Вечер, посвящен Дню молодежи в СПТУ-7] // Элстин зәңгс = Элист. новости. 1999. 25 июня. № 76. C. 1 .

Хугаев И. С. Осетинская русскоязычная литература: генезис и становление: автореф. дис. ... д-ра филол. наук.: 10.01.02. М., 2010. $24 \mathrm{c}$.

Хулхачиева В. Прерванная песня // Время Калмыкии. 2001. № 10. 16 марта. С. 3.

Цеденова С. Н. Диалог сокровенный, доверительный: [О кн. «Взлететь над мира суетой»] // Элстин зәңгс = Элист. новости. 1994. 26 фев. 4 марта. № 9. С. 9.

Чанкаева Т. А. К типологии русско-карачаевских связей // Этнонациональная ментальность в художественной литературе: Мат-лы Всерос. науч.-практ. конф. (г. Ставрополь, 22-24 сент. 1999). Ставрополь: Изд-во СГУ, 1999. С. 234-241.

«Час речи пробил не спеша...»: [К выходу книги «Час речи»] // Новая неделя. 2002. 23 авг. № 34. С. 15.

«Час речи» - это диалог времен: [Беседа с поэтом Р. М. Ханиновой о новой книге / Вела В. Андреева] // Хальмг үнн = Калм. правда. 2002. Ноха сарин 26 (4 сент.). № 166. С. 4.

Час речи: [Анонс книги «Час речи»] // Калм. ун-т. 2002. 14 сент. № 19-20. С. 3.

Чащина Л. Г. Русская литература Горного Алтая: Эволюция. Тенденции. Пути интеграции: автореф. дис. ... д-ра филол. наук: 10.01.01. Томск: Томск. ГУ, 2004. 34 с.

Червяченко Г. А. Поэма в советской литературе. Ростов н/Д: Изд-во Рост. ун-та, 1978. 187 с. 
Четырева Б. «Час речи»: [О презентации кн. «Час речи» в Нац. б-ке им А. М. Амур-Санана] // Хальмг үнн = Калм. правда. 2003. Моһа сарин 4 (7 марта). № 48. С. 4.

Четырова Л. Б. Кто ты, друг степей калмык? (К вопросу о способах этнической идентификации) // Материальные и духовные основы калмыцкой государственности в составе России (к 360-летию со дня рождения хана Аюки): Мат-лы Междунар. науч.-практ. конф. (г. Элиста, 22-24 мая 2002). В 2 ч. Элиста: КалмГУ, 2002. Ч. 2. С. 66-69.

Чонгонов В. О поэтах молодых и не очень: Краткий обзор поэтических новинок: [В частности о сб. Р. Ханиновой «Взлететь над мира суетой»] // ЭЖ Калмыкия плюс. 1997. № 31 (авг.). С. 11.

Чонгонов В. Римма Ханинова // ЭЖ Калмыкия плюс. 1997. № 31 (авг.). С. 11.

Чонгонов В. Я чуть-чуть подожду: [стихотворение в память Д. Насунова] // Рос. Вести в Калмыкии. 1995. 25 марта.

Чумаченко В. К. Жанрово-стилевые тенденции в современной русской советской лирике (к теории малых лирических форм): автореф. дис. ... канд. филол. наук: 10.01.08. М.: Ин-т. Миров. лит. им. А. М. Горького, 1987. 24 с.

Шанский Н. М. Лингвистический анализ стихотворного текста. М.: Просвещение, 2002. 224 с.

Шовадаева С. В. Детская поэзия Риммы Ханиновой: Герои, сюжеты, поэтика // Круг детского чтения сегодня: герои, сюжеты, поэтика: Мат-лы регион. науч.-практ. конф. (г. Ставрополь, 1415 октября 2005). Ставрополь: Ставроп. кн. изд-во, 2005. Вып. I. С. 107-111.

Эбаноидзе А. Л. Судьба. Язык. Творчество // Дружба народов. 2009. № 3. С. 209-217.

Эльдышев Э. А. Живу на свете плача и смеясь... // Известия Калмыкия. 1997. 31 мая. № 109-110. С. 10.

Эрдни-Горяева В. Мир на Кавказе через ... антологию литературы: [О выходе «Антологии литературы народов Северного 
Кавказа», куда включены стихи династии Хониновых] // Изв. Калмыкии. 2003. 9 авг. № 185. С. 1.

Эрдниев У. Э. Калмыки. Историко-этнографический очерк. Элиста: Калмиздат, 1970. 307 c.

Эрендженов К. Э. Золотой родник. Элиста: Калм. кн. изд-во, 1990. $127 \mathrm{c}$.

Юнг К. Г. Душа и миф. Шесть архетипов. Киев: Порт-рояль; Москва: Совершенство, 1997. 382 с.

Юрченко Т. Г. Сравнение // Литературная энциклопедия терминов и понятий. М.: НПК «Интелвак», 2003. С. 10-22.

Я слышу, как растут, вздыхая, травы...: [О творчестве Р. Ханиновой] // Эколог. газ. Калмыкии 45х46. 2001. № 3 (62) март. С. 6.

Якушева Г. В. Архетип // Литературная энциклопедия терминов и понятий. М.: НПК «Интелвак», 2003. С. 59-60.

Яцковская К. Приношение поэту: О книге Михаила Хонинова и Риммы Ханиновой «Час речи» // Элист. панорама. 2004. 1 июля. № 38. C. 15.

\section{II \\ Источники \\ Книги С. Балыкова}

Девичья честь: Историко-бытовая повесть. Элиста: АПП Джангар, 1993. $283 \mathrm{c}$.

Заламджа: повести и рассказы; Б-ка Мемориала «Донские казаки в борьбе с большевиками»; [сост. Е. С. Ремилева], 2013. 312 с.

Сильнее власти: сборник рассказов. Мюнхен, 1976.

\section{Произведения С. Балыкова, опубликованные}

\section{в периодической печати}

Ассараев сон: [рассказ] // Хальмг үнн = Калм. правда. 1994. Үкр сарин 13 (16 ноября).

Воспоминания о Зюнгарском полку: литература калмыцкого зарубежья // Теегин герл. 1993. № 3. С. 88-100. 
Две атаки; Судьба; Смерть; Лампадка божья; Наши черти: [рассказы] // Теегин герл. 1994. № 3. С. 111-124.

Ковыльный шелест: [рассказ] // Хальмг үнн = Калм. правда. 1994. Үкр сарин (15-18 ноября).

От матери: [рассказ] // Хальмг үнн = Калм. правда. 1994. Бар сарин (5-7 декабря).

Победа. Отцы: [рассказы] // Хальмг үнн = Калм. правда. 1994. Үкр сарин (19-22 ноября).

Смерть; Лампадка божья: [рассказы] // Хальмг үнн = Калм. правда. 1994. Бар сарин (5-7 декабря).

\section{Книги Д. Насунова}

Голоса расстояний: стихи; ред. Д. Кугультинов. Элиста: Калм. кн. изд-во, 1971. 62 с.

Полет копья: стихи; ред. О. Манджиев. Элиста: Калм. кн. издво, $1971.61 \mathrm{c}$.

Поселенцы: стихи; предисл. В. Сидорова. М.: Современник, 1977. $78 \mathrm{c}$.

Тамариск: стихи; предисл. и сост. Д. Б. Пюрвеева. М.: Современник, $1982.78 \mathrm{c}$.

\section{Произведения Д. Насунова, опубликованные в коллективном сборнике}

Здесь ты не встретишь броской красоты; Кочевье; Родной язык; Памяти моего отца; Украинскому другу; Земля моя легендами богата; Джангарчи; Джангарчи; Вдали синеют дрофы бугорками; Узором никого не удивить; Тишина // Поэты Калмыкии: антология на калм. и рус. яз. Элиста: ГУ «Издат. дом “Герел”», 2009. С. 280282.

Узором никого не удивить...; Верблюд; В телеге; В пути; Маме; В село приехал на черешню...; Раздумья в пути; В степном краю озер и рек немало...: Андрею Далаеву; Альмана; В тире: мастеру спорта по стрельбе из пистолета Галине Эдеевой; Тюльпан; Баллада о верности: Вере М.; Бумба; Памяти моего 
отца; Хотонцы; отрывок из поэмы; Вновь прячет взгляд знакомая девчонка.... памяти Андерсена: [Стихи] // Белая дорога: [сб. стихов] / Г. Кукарека, Д. Насунов, Л. Петрова, А. Сусеев, Д. Шанаев; ред. О. Л. Манджиев. Элиста: Калм. кн. изд-во, 1976. С. 26-48.

\section{Произведения Д. Насунова, опубликованные в периодической печати}

А может звезды это души... // Комсомолец Калмыкии. 1990. 7 ноября. № 130. С. 4.

Адьян: [Рассказ] // Комсомолец Калмыкии. 1975 (15 ноября). № 137 (3268). С. 3-4.

Акация: [Стихотворение] // Комсомолец Калмыкии. 1967. 27 января. №12. С. 4.

Баллада о верности; Альмана: [Стихи] // Теегин герл. 1975. № 3. С. $82-85$.

Баллада о партизанке Тамаре Хахлыновой: [Стихотворение] // Комсомолец Калмыкии. 1977 (4 октября). № 119 (3565). С. 3.

Баллада о спасителях: [Стихотворение] // Комсомолец Калмыкии. 1977. (17 ноября). № 140 (3584). С. 4.

Бил пулемет отчаянно и хлестко; Снова на коне; Картошка: [Стихи] // Теегин герл. 1968. № 1. С. 69.

Бил пулемет отчаянно и хлестко; Снова на коне; Картошка: [Стихи] // Теегин герл. 1968. № 1. С. 69.

Ботхн: [Рассказ] // Комсомолец Калмыкии. 1976 (15 января). № 6 (3293). С. 4.

Бумба: [Стихотворение] // Комсомолец Калмыкии. 1977 (1 ноября). № 131 (3577). С. 3.

Верблюд: [Стихотворение] // Теегин герл. 1973. № 4 (58). C. 134.

Верблюд: [Стихотворение] // Теегин герл. 1973. № 4. С. 134.

Вот на восток бегут степные травы; С недавних пор; Я двигаюсь плавнее: [Стихи] // Теегин герл. 1973. № 3. С. 133.

Всяк графоман - он злой...: [Стихотворение] // Комсомолец Калмыкии. 1979 (4 января) (спецвыпуск). № 157 (3914). С. 4. 
Вы в детстве на коне не скакали: [Стихотворение] // Авангард. 1977 (3 сентября). № 106 (2686). С. 4.

Где шли бои...; Герою Советского Союза Эрдни Деликову; Запах полыни: [Стихи] // Комсомолец Калмыкии. 1967. 24 ноября № 143. C. 3 .

Гости с Кавказа; Степь и люди: [Стихи] // Московский комсомолец. 1971 (11 июня).

Добрым быть ничуть не тяжело; Родной язык: [Стихи] // Теегин герл. 1970. С. 106.

Добрым быть; Я не живу безумно; Есть у солнца цвет: [Стихи] // Теегин герл. 1970. № 4. С. 105-106.

Земля моя легендам богата; Кочевье; Степь и люди; Тишина; Верблюду; Украинскому другу: [Стихотворения] // Теегин герл. 2012. № 3. 24-31.

Кочевье; Родной язык; Памяти моего отца; Украинскому другу; Джангарчи; Тишина: [Стихотворения] // Поэзия Калмыкии: антология на калм. и русск. яз. Элиста: Издат. дом «Герел», 2009. С. 280-282.

Маныч манит; Растет в степи кустарник тамариск; Не потому что ближними обижен: [Стихи] // Теегин герл. 1974. № 4 (62). C. 199.

Маныч мой, синевато-зеленый: [Стихотворение] // Советская Калмыкия. 1976 (25 марта). № 60 (7549).

Маныч угрюмый: [Отрывок из поэмы] // Комсомолец Калмыкии. 1967. 29 октября (№ 132). С. 4.

Меня постигла неудача: [Стихотворение] // Теегин герл. 1968. № 1. С. 69.

Мой брат, Вано, нам счастья не дано; Всяк графоман; Моя башка бурлящий глобус: [Стихи] // Комсомолец Калмыкии. 1976 (13 января). № 5 (3292). С. 4.

Мой дорогой, веселый враль...: [стихотворение] // Ленинский путь. 1992. 11 июля. № 77 (8504). С. 4.

Награда: [Стихотворение] // Элистинская панорама. 2012. 21 июля. № 103. С. 4. 
Над обрывом, на фоне... // Известия Калмыкии. 1994. №.46. C.4.

Намек Кеедя; Родной язык: [Стихи] // Теегин герл. 1974. № 2. C. 142.

Намек Кеедя; Родной язык: [Стихи] // Теегин герл. 1974. № 2. C. 142.

Не потому, что ближними обижен; Растет в степи кустарник тамариск; Маныч манит здешних и нездешних: [Стихи] // Теегин герл. 1974. № 4. С. 99.

Ну, а я сосед и только: [Стихотворение] // Комсомолец Калмыкии. 1967. 14 апреля. № 46. С. 3.

Памяти моего отца; Верблюд: [Стихи] // Комсомолец Калмыкии. 1975 (26 июля).

Плясал цыган на тротуаре: [Стихотворение] // Комсомолец Калмыкии. 1976 (7 января). № 1 (3288). С. 4.

Поселенцы: [отрывок из поэмы] // Теегин герл. 1975. № 1. C. 124-130.

Прозрение: [Стихотворение] // Теегин герл. 1967. № 4. С. 51.

Пусть даже одна строка...: [публицистический очерк] // Комсомолец Калмыкии. 1976. 22 января. № 9. С. 4.

Пустяк: [Стихотворение] // Теегин герл. 1968. № 4. С. 84.

Ради бога, прошу вас, не лезьте под кожу // Известия Калмыкии. 1994. № 46. C. 4.

Разговор у костра: [Поэма] // Комсомолец Калмыкии. 1976 (1 июля). № 78 (3365). С. 4.

Родной язык: [Стихотворение] // Элистинские новости. 1991. һаха сарин (21 сент). № 38 (90). С. 11.

Родной язык; Памяти моего отца; Награда; Брату Ивану; Степь и люди; Баллада о верности: [Стихотворения] // Теегин герл. 2010. № 6. С. 40-45.

Самостоятельное решение: [Рассказ] // Теегин герл. 1972. № 3. C. 69-76.

Сестре Любе: [Стихотворение] // Теегин герл. 1978. № 3. C. 148. 
Случай в кино: [Стихотворение] // Теегин герл. 1968. № 1. С. 69.

Степь и люди; Запах полыни: стихи / Джангр Насунов // Души прекрасные порывы: молодая поэзия и проза Калмыкии / сост. Б. Б. Пинчук. Элиста, 1971. С. 14-15.

Тюльпан; В степном краю озер и рек немало: [Стихи] // Теегин герл. 1974. № 3. С. 162.

Узором никого не удивить; Ханский подарок; Маме: [Стихи] // Теегин герл. 1975. № 4. С. 135-142.

Узором никого не удивить...; Верблюд; В телеге; В пути; Маме; В село приехал на черешню...; Раздумья в пути; В степном краю озер и рек немало...: Андрею Далаеву; Альмана; В тире: мастеру спорта по стрельбе из пистолета Галине Эдеевой; Тюльпан; Баллада о верности: Вере М.; Бумба; Памяти моего отца; Хотонцы; отрывок из поэмы; Вновь прячет взгляд знакомая девчонка.... памяти Андерсена: [Стихи] // Белая дорога: [сб. стихов] / Г. Кукарека, Д. Насунов, Л. Петрова, А. Сусеев, Д. Шанаев; ред. О. Л. Манджиев. Элиста: Калм. кн. изд-во, 1976. С. 26-48.

Улица родная (памяти героя Советского Союза А. Г. Митяшкина): [Стихотворение] // Комсомолец Калмыкии. 1967. 27 января. № 12. C. 4.

Фотопортрет; Тишина: [Стихи] // Известия Калмыкии. 1995 (25 апреля). № 76 (873). С. 3.

Ханский подарок; Маме: [Стихи] // Теегин герл. 1975. № 4. C. $140-142$.

Хочу, чтоб вы не ведали печали; Петь хотел и хочу без обмана; Бреду без друга и без денег...; Ах, боже мой, куда же лезли вы...? // Комсомолец Калмыкии. 1990. 7 ноября. № 130. С. 3.

Шоферу: [Стихотворение] // Комсомолец Калмыкии. 1967. 14 апреля (№ 46). С. 3.

Я, как шофер: [Стихотворение] // Комсомолец Калмыкии. 1967. 1 марта. № 27. С. 3. 


\section{Книги О. Манджиева}

Ад номер семь. Элиста: АПП Джангар, 2003. 448 с.

Амуланга: повесть. Элиста: Калм. кн. изд-во, 1987. 91 с.

Дорога в один дун: повесть. Элиста: Калм. кн. изд-во, 1988. $206 \mathrm{c}$.

Небесный родник. Стихи. Элиста: Калм. кн. изд-во, 1982. 82 с.

Острие копья: [повесть и рассказ]. Элиста: Калмиздат, 1976. $103 \mathrm{c}$.

Приключения Эльзятки в мышином государстве. Повестьсказка в 2 книгах. 2-е изд. Элиста: Калм. кн. изд-во, 1991. 245 с.

Скачки: [рассказы]. Элиста: Калмиздат, 1972. 74 с.

\section{Произведения О. Манджиева, опубликованные в коллективном сборнике}

Учитель; Поколение послевоенное; Птица; Камень // Поэты Калмыкии: антология на калм. и рус. яз. Элиста: ГУ «Издат. дом “Герел”», 2009. С. 298-299.

\section{Произведения О. Манджиева, опубликованные в периодической печати}

Ад номер семь: [роман] // Теегин герл = Свет в степи. 2000. № 4. С. 35-73. Продолжение. № 5. С. 26-76.

Амуланга: [повесть] // Теегин герл = Свет в степи. 1986. № 1. C. 19-64.

Вечер пахнет горькой полынью [стихотворение] // Комсомолец Калмыкии. 1977. 17 ноября.

День рождения: [рассказ] // Теегин герл = Свет в степи. 1979. № 3. С. 131-135.

Детство, которое мы предали: киноповесть // Теегин герл = Свет в степи. 1990. № 5. С. 52-72.

Дорога в один дун: [повесть] // Теегин герл = Свет в степи. 1987. № 3. С. 25-47.

Змея. Рассказ // Теегин герл = Свет в степи. 1971. № 2. С. 129132. 
И вечно возвращаться // Теегин герл = Свет в степи. 1983. № 1. С. $12-45$.

И созрели плоды...// Теегин герл = Свет в степи. 1991. № 5. C. 9-28.

Как одиноко выглядит она: [Стихи] // Теегин герл = Свет в степи. 1977. № 2. С. 82-85.

Какое утро [стих] // Теегин герл = Свет в степи. 1976. № 4. C. 162.

Каникулы. Рассказ // Теегин герл = Свет в степи. 1973. № 4. C. $130-132$.

Мальчишка с бантиками. Повесть // Теегин герл = Свет в степи. 1974. Начало. № 2, 3, 4. 1975. № 3. С. 89-168. 1976. № 4. С. 162.

Мы любили ее // Теегин герл = Свет в степи. 1970. № 4. С. 99103.

На земле, где ровесник погиб... [стихи] // Теегин герл = Свет в степи. 1972. № 4. С. 143.

Рождение стиха; Ночной разговор; Рае; Письмо: [стихи] // Комсомолец Калмыкии. 1981. 6 октября.

Скука. Рассказ // Теегин герл = Свет в степи. 1971. № 4. С. 99105.

Судный день: киноповесть // Теегин герл = Свет в степи. 1992. № 5. С. 41-71.

Утро; Замру, прижавшись ухом к камню...: [стихи] // Совет. Калмыкия. 1977. 18 янв. С. 4.

\section{Книги В. Лиджиевой}

Из рода журавлиных: Стихи. Элиста: Калм. кн. изд-во, 1990. $67 \mathrm{c}$.

Обращение к ливню: Стихи. Элиста: Калм. кн. изд-во, 1982. $46 \mathrm{c}$.

Тридцать роз: Стихи. Элиста: Калм. кн. изд-во, 1993. 128 с. 


\section{Произведения В. Лиджиевой произведения, опубликованные в коллективном сборнике}

День влюбленных: сб. стихов / Б. Мунянова, В. Лиджиева, Р. Ханинова. Элиста: АПП «Джангар», 1997.

Я не сижу за письменным столом; Поилица-кормилица моя; И вот подул, и носится по свету; Я читаю руки отца; Я бы уехала, если верблюжья колючка...; Кто бы платье мне сшил; Степная дорога; Собаки ваши лют на меня; Сентябрина; 22 июня; Выселение; Не может быть такого, чтобы было...; А знаешь, я скучаю по Москве // Поэты Калмыкии: антология на калм. и рус. яз. Элиста: ГУ «Издат. дом “Герел”», 2009. С. 315-317.

\section{Произведения В. Лиджиевой произведения, опубликованные в периодической печати}

«Две подружки», «Неужеле вся жизнь - ожидание», «Наверное, все в дни юности своей...», «Все стихи написаны ночью...», «Мне цвет не какой-нибудь, а голубой...», «Москва и Элиста», «На ваганьковском кладбище...», «Пора предосенняя, что ты готовишь...», «Целый день на кухне торчу...», «Я порой хочу этот город оставить...», «Грудной девчонке...», «Совершеннолетняя»: Стихи // Теегин герл = Свет в степи. 1995. № 2. С. 72-78.

«Люблю стихи», «Мой поезд не догонишь...» // Комсомолец Калмыкии. 1988. 7 октября. С. 4.

«Не зима на дворе...», «Говоришь, что привыкла цветы получать?...», «Я хочу, чтоб мне не лгали...», «Все говорят о политике...» и др. [Стихи] // Теегин герл = Свет в степи. 1993. № 3. C. $18-24$.

«О весне я в юности писала...», «Я свет потушу...», «Уезжаешь?...», «Стихи и осенние листья...»: Стихи // Теегин герл = Свет в степи. 1994. № 2. С. 46-52.

«Родной город», «Есть на свете чудеса...», «Пускай все это летом»: стихотворения // Комсомолец Калмыкии: Стихи // Комсомолец Калмыкии. 1991. 26 февр. С. 3. 
«Те зимы все же я пережила», «Старый друг поставь свое плечо...», «Дыхание войны....», «Посленовогоднее», «Февраль», «Ночное»: [Стихи] // Теегин герл = Свет в степи. 1995. № 2. С. 3-8.

Лирическое платье голубое; Как эта зима холодна; А знаешь, друг, я все еще умею; О, Париж; вот и осталось кого-то любить понарошку; Ах, какая выдалась весна; Моя безумная мечта; Ты говоришь, что любишь; Докажи...; Когда я думала, что все меня забыли; Я думаю о тех, кого люблю; Не могу я больше жить без стихов, не могу: [стихи] // Теегин герл = Свет в степи. 1997. № 1 . C. 77-80.

Маленький рай. Мой любимый Тверской... [Стихи] // Теегин герл = Свет в степи. 2009. № 4. С. 101-103.

Слово о современнике. Поэма // Теегин герл = Свет в степи. 2005. №8. 2008. № 1. C. 43-45.

Те зимы все же я пережила; О старый друг; Вечереет; Дыхание войны; Посленовогоднее; Февраль; Ночное: [стихи] // Теегин герл = Свет в степи. 1995. № 2. С. 3-8.

Я помню себя; Мое село; Свеча милосердия: [стихи] // Авангард. 1998. 29 июня (№ 51). С. 4.

\section{Книги Р. Ханиновой}

Буква А: стихи для детей. Элиста, 2010.

Взлететь над мира суетой: стихи. Элиста: АПП «Джангар», 1994. $240 \mathrm{c}$.

Зимний дождь: стихи. Элиста: АПП «Джангар», 1993. 16 с.

Умная мышка (По мотивам сказок народов мира): [Стихи для детей] // Байр = Радость. № 5. 2002. 14 с.

\section{Соавторство}

День влюбленных: сб. стихов / Б. Мунянова, В. Лиджиева, Р. Ханинова. Элиста: АПП «Джангар», 1997. 229 с.

Ханинова Р. М., Ничипоров И. Б. «На перекрестках Софии и Веры...»: Стихи, поэмы, эссе / Римма Ханинова; Илья Ничипоров. Элиста: АПП «Джангар», 2005. 256 с. 
Хонинов М. В., Ханинова Р. М. Стану красным тюльпаном: стихи, поэмы, переводы, повесть. Элиста: НПП «Джангар», 2010. $736 \mathrm{c}$.

Хонинов М. В., Ханинова Р. М. Час речи: Стихи и поэмы / Михаил Хонинов; Римма Ханинова. Элиста: АПП «Джангар», 2002. $240 \mathrm{c}$.

\section{Произведения Р. Ханиновой, опубликованные в коллектив- ных сборниках, монографиях, периодической печати}

«А жизнь, как тишина осенняя, подробна...»; Борису Пастернаку: Цикл стихов // Теегин герл = Свет в степи. 2005. № 4. C. $115-117$.

«В них явственно чудо добра»: [Стихотворение] // Изв. Калмыкии. 1993. 21 мая (№ 93). С. 2.

«Две малых родины на карте у меня...»; «В чужой земле родные мне могилы...»; «Им вспоминать о прошлом трудно...»; «Он под запретом был...»; «Им снилась степь в раздолье ковыля...»; «Спецпоселенье, спецкомендатура...»: Из цикла «Сибирской памяти тетрадь...»: [Стихи] // Элстин зәңгс = Элист. новости. 1993. 11-17 сент. (№ 37). С. 5.

«Земную жизнь пройдя до половины...»; «Все это было, было, было...»; «Оставил. Как будто нарочно забыл...»; «Ненавидя люблю. Свору диких собак...»; «Февраль...»; «Время раны не лечит...»: [Стихи] // Теегин герл = Свет в степи. 1992. № 7. С. 97-99.

«Знаешь, очень мне хочется верить...»: [Стихотворение] // Комсомолец Калмыкии. 1991. 9 февр. (№ 9). С. 3.

«Мне жизнь и матерью и мачехой была...»: [Стихотворение] // Изв. Калмыкии. 1993. 23 марта (№ 53). С. 3.

«Мы так порою опрометчиво беспечны...»; «Вся жизнь непредсказуемый сюжет...»; Музыка; «Монах тибетский пред собой метет...»: [Стихи] // Изв. Калмыкии. 1993. 26 нояб. № 218. C. 3 .

«На вкус и цвет друзей, известно, нет...»: [Стихотворение] // Элстин зәңгс = Элист. новости. 2002. 7 июня. № 41. С. 1. 
«О, эта детства безмятежность...»; Плачет в потемках ребенок; Восточные мотивы; «Входите узкими вратами...»: [Стихи] // Теегин герл = Свет в степи. 1991. № 7. С. 121-122.

«От всего человека вам остается...»: Памяти Бродского: [Цикл стихотворений] // Калм. ун-т. 2003. 6 нояб. № 13. С. 7. Окончание. Начало. 14 окт. № 12. С. 5.

«Пейзаж весны в оконной раме...»: [Стихотворение] / Римма Ханинова // Элстин зәңгс = Элист. новости. 1993.7 февр. 5 марта № 9.

«Пейзаж весны в оконной раме...»: [Стихотворение] // Элстин зәңгс = Элист. новости. 1993. 27 февр. 5 марта. № 9. С. 9.

«Прости меня за все, что не случилось...»: [Прозопоэзия] // Новая неделя. 1996. 6 сент. № 36. С. 6; Элстин зәңгс = Элист. новости. 1992. 27 нояб. -3 дек. № 48. С. 6.

«Спецпоселенье, спецкомендатура...»: [Стихотворение] // Изв. Калмыкии. 1991. № 6. С. 85-87.

«Спецпоселенье, спецкомендатура...»: [Стихотворение]. На калм. пер. В. Шуграевой, на англ. яз. пер. К. Коуплонд // Теегин герл $=$ Свет в степи. 2009. 28 дек. № 77. С. 5.

«Степные колыбельные мотивы...»: [Стихотворение] // Изв. Калмыкии. 1991. 6 нояб. № 46. С. 5.

«Четверостишия»; Два торговца; Три калача и одна баранка; Слепой и молоко; Ноша; Летучая мышь; Первые шаги; Цапля, рыбы и рак: [Стихи] // Молодежь Калмыкии. 1993. 23 июня. № 24. C. 3 .

«Шелковое покрывало»: Из цикла «Древние метаморфозы»: [Стихотворение, посвящ. Федору и Ирине Конюховым, открывающим вновь великий Шелковый путь] // Хальмг үнн = Калм. правда. 2002. Така сарин 2 (12 июля). № 127. С. 4; Шин жирһл = Новая жизнь. 2002. 18 июня. № 45. С. 3.

Автограф; Тень птицы; Жизнь взаймы: [Стихи] // Советская Калмыкия. 1993. 28 авг. № 97. С. 3.

Акация, Баллада, Анатомия любви: [Стихи] // Теегин герл = Свет в степи. 1997. № 1. С. 107-109. 
Аксиомы: [Цикл стихов] // Теегин герл = Свет в степи. 1994. № 5. С. 20-22.

Алфавит; Читательница; Телефон; Бант: [Стихи для детей] // Байр = Радость. 1995. № 6. С. 12.

Бабье лето: [Стихотворение] // Новая неделя. 1994. 19-25 мая. № 38. C. 1 .

Баллада о войне: [Стихотворение] // Рассвет. 1999. 20 февр. № $15-16$. С. 3 .

Баллада о войне: [Стихотворение] // Санл = Память. В 2 кн. Элиста, 1995. Кн. 1. С. 224.

Башня: По мотивам буддийских притч; [Стихотворение] // Новая неделя. 1995. 3-9 апр. № 14. С. 7.

Беда; Молчание ягнят; По мотивам буддийских басен; Голова и хвост змеи; Утка и месяц; Четверостишия: [Стихи] // Изв. Калмыкии. 1993. 11 июня. № 107. С. 2.

Белый Старец - Цаган Овген: [Стихотворение] // Элстин зәңгс = Элист. новости. 1994. 28 мая-3 июня. № 22. С. 7.

Бессонница; Зимний дождь; Восемь граммов; Зул: [Стихи] // Теегин герл = Свет в степи. 1993. № 4. С. 75-76.

Братья сели в чудесное седло сургали: [Рассказ] // Советская Калмыкия. 1972. 17 авг. № 161. С. 4.

В тени Конфуция: [Из цикла стихов] // Калм. ун-т. 2002. 28 нояб. № 25-26. С. 7; Утро Калмыкии. 2002. 19-25 янв. № 3. С. 7.

В тени Конфуция: [Цикл стихотворений]; Тень и след: [Стихотворение, посвящ. А. Бурыкину] // Теегин герл = Свет в степи. 2003. № 3. С. 46-52.

В чужой земле родные мне могилы: [Стихотворение] // Ленинец. 1998. 29 дек. № 104. С. 5.

Взлететь над мира суетой...: [Прозопоэзия] // Комсомолец Калмыкии. 1991. 2 июля. № 65. С. 3.

Вкус жизни: По мотивам буддийских притч; «Завет отцовский непреклонен...»; Зул: Стихи // Антология. Литература народов Северного Кавказа. Т. 1. Поэзия. Ч. 1. Пятигорск, 2003. С. 689-690. 
Волк и баран; Комар и дуб; Умная мышка: Сказки народов мира (Для детей изрядного возраста): [Стихи] // Элстин зәңгс = Элист. новости. 2002. 22 февр. № 14. С. 12.

Волшебство любви: (Сказка для взрослых): [Прозопоэзия] // Элстин зәңгс = Элист. новости. 1991. 5 окт. № 40. С. 8.

Все движет Женщина-Любовь: [Поэма] // Теегин герл = Свет в степи. 1999. № 4. С. 115-128. Окончание. Начало: № 3. С. 95-99.

Второй индюк; Комар и дуб; Деревенский писец; Сказка, которая не кончается: Из цикла «Сказки народов мира (для детей изрядного возраста): [Стихи] // Байр = Радость. 2003. № 6. С. 6.

Второй индюк; $\mathrm{O}$ чем собака думает зимой и летом; Деревенский писец; Смышленый мальчик; Шакал и черепаха: [Стихи]: Сказки (для детей изрядного возраста) // Элстин зәңгс = Элист. новости. 2002. Туула сар. 24-26 (6-8 февр.). С. 8.

Горячий мед; Недостаток; Две головы; Мудрость: Из цикла стихов «По мотивам буддийских притч» // Изв. Калмыкии. 1994. 4 окт. № 172. С. 2.

Гостья; О дефиците: [Стихи] // Сов. Калмыкия. 1991. 8 марта № 46. C. 3.

Две женщины: [Стихотворение] // Вечер. Элиста. 2003. 7 марта. № 17-18. С. 5.

Дедовская плеть: [Стихотворение] // Изв. Калмыкии. 1993. 26 июня. № 117. С. 3.

День влюбленных: [Стихотворение] // Новая неделя. 1995. 13-19 февр. № 7. С. 1.

День и ночь; По мотивам буддийских басен; Волк и лекарство; Старец и волк; Дойная корова; Наследство; Обезьяна и горох; Четверостишия: Из цикла стихов «По мотивам буддийских притч» // Элстин зәңгс = Элист. новости. 1993. 14-20 августа. № 33. С. 9.

День Святого Валентина: [Стихотворение]: Моим одноклассникам // Новая неделя. 1997. 14 фев. № 7. С. 8.

Дни Алкиона: [Стихотворение] / Римма Ханинова // Элстин зәңгс = Элист. новости. 2002. 9 апр. № 26. С. 8. 
Жесток обычай Чингисханов: [Стихотворение, посвящ. В. Каруеву] // Сов. Калмыкия. 1994. 11 июня. № 65. С. 3.

Завет отцовский непреклонен: Из цикла «Разговор с отцом» // Калм. ун-т. 2004. 6 мая. № 6. С. 3.

Звездный час; Есть в мире узы роковые...; Поэты не похожи на себя...; Ремесло; Когда мне говорят стихи: [Стихи] // Теегин герл = Свет в степи. 1993. № 8. С. 47-49.

Звуки вечности: [Стихотворение]: Герел Нуровой, автору литографии «Звуки вечности» // Элстин зәңгс = Элист. новости. 1996. 10-15 дек. № 50. С. 3.

Здравствуй, это я!; Желтый лев; Благословение; Волшебство любви: [Стихи] // Сов. Калмыкия. 1990. 8 марта. № 48. С. 3.

Зеркало; Авалокитешвара; Ваятель: [Стихи] // Рос. вести в Калмыкии. 1995. 12 авг. № 28. С. 17.

Зимние песни, Бездонное черное небо, День угас // Теегин герл $=$ Свет в степи. 2001. № 3 .

Зимний дождь: [Стихотворение] / Римма Ханинова // Сов. Калмыкия. 1993. 25 февр. № 22. С. 3.

Зул и Цаган сар в Америке // Перевод стихов с калм. яз. В. Шуграевой // Теегин герл = Свет в степи. 2012. № 6. С. 113.

Зул: [Стихотворение] / Римма Ханинова // Элстин зәңгс = Элист. новости. 1996. 1-9 дек. № 49. С. 6; Сел. труженик. 2003. 16 дек. № 98. С. 1.

Калмыцкая песня: [Посвящ. нар. артистке России В. Гаряевой]; Зеленая тара: [Стихи] // Хальмг үнн = Калм. правда. 1994. Лу сарин 24 (6 марта). № 39. С. 2.

Калмыцкий язык: [Стихотворение] // Молодежь Калмыкии. 1991. 30 нояб. № 14. С. 4.

Ключи разума: (Читая и перечитывая «Оюн түлкүр»): [Цикл стихов] / Римма Ханинова // Хальмг үнн. 2004. 21 дек. № 260. С. 14.

Круг бытия; Мой шар; Воспоминание; Под шепот дождя; Прозрение: [Новые стихи] // Сов. Калмыкия. 1989. 7 окт. № 191. C. 4 . 
Круги; Ангел-хранитель: [Стихи] // Сов. Калмыкия. 1991. 6 июля. № 127. С. 3.

Круговорот: [Стихотворение] // Изв. Калмыкии. 1992. 7 марта. C. 4 .

Курсив мой; «Не баловница я удач...»: [Стихи] // Сов. Калмыкия. 1993. 25 дек. № 148. С. 3.

Ландшафт истории (размышления по поводу): [стихотворение] // Теегин герл = Свет в степи. 2006. № 6. С. 59-60.

Легенда о Джангарчи. Пьеса в 2-х действ. с прологом / Р. Ханинова // Теегин герл = Свет в степи. 2009. № 5. С. 20-48.

Легенда о Джангарчи. Пьеса в 2-х действиях с прологом // Теегин герл = Свет в степи. 2009. № 4. С. 24-45; № 5. С. 20-48.

Легенда: [Стихотворение] // Новая неделя. 1998. 13 фев. № 6. C. 10 .

Мастер: [Стихотворение]: Посвящ. П. Надбитову // Изв. Калмыкии. 1995. 13 янв. № 7-8. С. 3.

Миллениум: [Стихотворение] // Изв. Калмыкии. 1999. 31 дек. № 263-264. C. 10.

Мир спасет красота: Прозопоэзия // Элстин зәңгс = Элист. новости. 1991. 13 мая. № 19. С. 7.

Мираж, Зеленый ветер, Романс: [Стихи] // Теегин герл = Свет в степи. 1993. № 8. С. 87.

Мужчине - дым, а женщине - огонь; Жизнь прожить - не степь верхом проехать: [Стихи] // Теегин герл =Свет в степи. 2008. № 1. C. 42-43.

На ветру: [Стихотворение] // Изв. Калмыкии. 1993. 15 апр. № 42. C. 3.

На остановке: [Стихотворение] // Изв. Калмыкии. 1991. 5 сент. № 4. C. 3.

Наедине с собою...: [Прозопоэзия] // Элстин зәңгс = Элист. новости. 1992. 7 марта. № 9. С. 7.

Неизвестный - Реквием в двух шагах от автора монумента «Исход и Возвращение», с эпилогом: [Стихотворение] // Изв. Калмыкии. 1997. 18 янв. № 11-12. С. 9. 
Новогоднее: [Стихотворение] / Римма Ханинова // Изв. Калмыкии. 1995. 30 дек. № 239-240. С. 5.

Ноктюрн осени; Предзнаменование; Мольба: [Стихи] // Сов. Калмыкия. 1991. 10 янв. № 6. С. 4.

Ноктюрн: [Стихотворение] // Сов. Калмыкия. 1991. 10 июля. C. 3 .

О любопытстве: [Стихотворение] // Сов. Калмыкия. 1990. 31 марта. № 63. С. 4.

Обычай предков - сдержанность всех чувств; Джангарчи; Владимиру Каруеву; Тибет; Окон-Тенгри; Ландшафт истории (размышления по поводу): [стихи] // Байкал. 2007. № 4. (июльавгуст). С. $48-51$.

Одуванчик: [Сказка] // Байр = Радость. 2002. № 12. С. 9-10.

Окон-Тенгри: [Стихотворение] // Изв. Калмыкии. 1994. 6 марта. № 39. С. 1.

Осенняя тишина: [Стихотворение] // Хальмг үнн = Калм. правда. 2005. Хөн сарин 18 (26 мая). № 89-90. С. 15.

Память сердца: [стихи] // Теегин герл = Свет в степи. 2005. № 2. C. 41-42.

Перечитывая М. Светлова, Н. Майрова, Н. Тихонова: [Стихотворение] // Теегин герл = Свет в степи. 2000. № 5. С. 78.

По мотивам буддийских притч; По мотивам японских преданий; Госпожа Кэса; Соломенная веревка: [Стихи] // Шамбала. 1994. № 1. С. 18-19.

Подкова над отчим порогом: [Цикл стихов] // Элстин зәңгс = Элист. новости. 1991. 21 сент. № 38. С. 5.

Понедельник; В диком поле; Ночная трава; Моим друзьям: [Стихи] / Римма Ханинова // Изв. Калмыкии. 1993. 14 авг. № 149. C. 3 .

Попугай: По мотивам буддийских притч: [Стихотворение] // Байр = Радость. 1994. № 11. С. 10.

Попытка прощания; Чужой; Предчувствие: [Стихи] // Элстин зәңгс = Элист. новости. 1990. 7 июля. № 27. С. 5. 
После любви: [Цикл стихов] // Новая неделя. 1994. 7-13 марта № 10. C. 5.

Последний вечер: [стихотворение] // Голос Кавказа. 2007. № 1. С. 152.

Поэтам: [Стихотворение] // Изв. Калмыкии. 1993. 30 дек. № 241. C. 2.

Разговор с отцом: [Цикл стихов] // Теегин герл $=$ Свет в степи. 1992. № 2. C. 7-8.

Рондо; Знакомому художнику: [Стихи] // Сов. Калмыкия. 1989. 8 марта. № 45. С. 3.

Сибирской памяти тетрадь...: [Стихотворение] // Элстин зәңгс = Элист. новости. 1998. 19-25 дек. № 52. С. 8.

Скрипка Паганини; Лотос; Сердце оливы; Чайный куст; «Спросил Учителя однажды ученик...»; «Возрасту жизни свой смысл и мера...»: [Стихи] // Южная звезда. 2005. № 1. С. 57-60.

Солнечный Лев: Поэма, посвящ. К. А. Тачиевой // Теегин герл = Свет в степи. 2002. № 3. С. 29-36. Окончание. Начало. 2001. № 6. С. 33-37.

Справедливый И: поэма (По мотивам китайской легенды) // Теегин герл = Свет в степи. 2010. № 2. С. 33-41.

Степные колыбельные мотивы...: [Стихотворение] / Римма Ханинова // Изв. Калмыкии. 1991. 6 нояб. № 46. С. 5.

Степные колыбельные мотивы...»; «Обычай предков сдержанность всех чувств...»; «Монах тибетский пред собой метет...»; Джангарчи: Владимиру Каруеву: [Стихи] // Калм. ун-т, 2005. 1 июля. № 9. С. 7.

Сторож у дороги: Из цикла «Древние метаморфозы»: [Стихотворение] // Хальмг үнн = Калм. правда. 2003. Така сарин 19 (17 июля). № 143-144. С. 4.

Струятся волосы...»; «Обычай предков сдержанность всех чувств...»: [Стихи] // Элстин зәңгс = Элист. новости. 1994. 26 февр. 4 марта. № 9. С. 9.

Судьба; Цветы запоздалые; Високосный год; Сыну; Номто Очирову: [Стихи] // Элстин зәңгс = Элист. новости. 1993. 29 мая 4 июня. № 22. С. 9. 
Сургаль: Из рассказов отца: [Рассказ] // Комсомолец Калмыкии. 1972. 13 июня. № 70. С. 3.

Талисман: [Стихотворение] // Элстин зәңгс = Элист. новости. 1990. 3 нояб. № 44. С. 9.

Тибет: [Стихотворение] // Изв. Калмыкии. 1994. 7 апр. № 60. C. 3 .

Тодо бичиг - ясное письмо: [Стихотворение] // Теегин герл = Свет в степи. 2006. № 8. С. 35-36.

Тодо бичиг — ясное письмо; Мужчине - дым, а женщине - огонь; Две жизни; Зул; Цаган сар - белый месяц; Пушкинские тексты; Чайный куст; Баллада о войне; Осенняя тишина: [Стихи] // Поэзия Калмыкии: антология. На калм. и рус. яз. Элиста: Издат. дом «Герел», 2009. С. 304-309.

Топонимика: [Стихотворение] // Комсомолец Калмыкии. 2003. 24-30 сент. № 36. С. 10.

Три числа: [Стихотворение] // Сов. Калмыкия. 1993. 7 авг. № 88. C. 3.

Ты мое начало и конец...: [Стихотворение] // Изв. Калмыкии. 1992. 29 февр. № 79. С. 2.

Урюс Сар: [Стихотворение] // Изв. Калмыкии. 1994. 31 мая № 93. C. 3.

Формула судьбы: [Поэма]: По мотивам сказки «Игра в шахматы» // Теегин герл = Свет в степи. 2004. № 6. С. 91-95; ТВДжангар. 2002. 23 янв. № 4. С. 11.

Цаган Сар - белый месяц: [Стихотворение] // Новая неделя. 1994. 14-20 февр. № 7. С. 6.

Чайный куст; Сердце оливы; Прут омелы; Лотос: Кеме Мантаевой; Цветок солнца: Из цикла «Древние метаморфозы»: [Стихи] // Хальмг үнн = Калм. правды. 2003. Лу сарин 11 (12 февр.). № 28. С. 4.

Час речи: [Отрывок из поэмы] // Элстин зәңгс = Элистинские новости. 1999. 6-12 февр. № 7. С. 7.

Час речи: [Поэма]: Посвящ. В. Н. Илюмжинову // Теегин герл = Свет в степи. 2000. № 1. С. 38-44. 
Шелковое покрывало. Ветка омелы. Сердце оливы: Из цикла «Древние метаморфозы»: [Стихи] // Время Калмыкии. 2004. 26 июля. № 7. С. 3.

Шепчущий мост: [Стихи] // Мунянова Б., Лиджиева В., Ханинова Р. День влюбленных: Сб. стихов. Элиста: АПП «Джангар» 1997. С. 139-229.

Щепчущий мост: [Стихотворение]: По мотивам япон. сказок // Изв. Калмыкии. 1998. 17 янв. № 10-11. С. 10.

Я не была на прошлой той войне...: [Прозопоэзия] // Элстин зәңгс = Элистинские новости. 1991. 29 июня. № 26. С. 8.

Я не была на той войне...: [Стихотворение] // Хальмг үнн $=$ Калм. правда. 2005. Мөрн сарин 29 (7 апр.). № 57-58. С. 14.

Я слышу, как растут, вздыхая, травы..; Ночная трава; Курсив мой; «Дороги пыльные, степные...»; «Цветок степной неприхотливый...»; «Луна, как с чаем пиала...»; «Природа к нам, пожалуй, милосердна...»; «Монах тибетский пред собой метет...»: [Стихи]; Степь: [Эссе] // Эколог. газ. Калмыкии 45х46. 2001. № 3 (62). март. С. 4. 
Научное издание

Делгир Юрьевна Топалова

\title{
Русскоязычная поэзия Калмыкии: лирика Д. Насунова и Р. Ханиновой
}

\author{
Монография \\ Подписано в печать 30.09.2014. \\ Формат 60х84/16. Усл. печ. л. 14,9. \\ Тираж 500 экз. Заказ № 20-14. \\ Компьютерная верстка и подготовка оригинал-макета \\ Татнинов Д. В. \\ Федеральное государственное бюджетное учреждение науки \\ Калмыцкий институт гуманитарных исследований \\ Российской академии наук \\ 358000 , г. Элиста, ул. Илишкина, 8
}


